TÁSSIA NEVES LOBÃO

DETECÇÃO DE Ureaplasma urealyticum E U. parvum NO TRATO UROGENITAL E A SUA RELAÇÃO COM POLIMORFISMOS GENÉTICOS E EXPRESSÃO DE CITOCINAS EM MULHERES ATENDIDAS NO MUNICÍPIO DE VITÓRIA DA CONQUISTA - BA

Dissertação apresentada ao Programa de Pós-Graduação em Microbiologia do Instituto de Ciências Biomédicas da Universidade de São Paulo, para obtenção do Título de Mestre em Ciências. 
TÁSSIA NEVES LOBÃO

DETECÇÃO DE Ureaplasma urealyticum E U. parvum NO TRATO UROGENITAL E A SUA RELAÇÃO COM POLIMORFISMOS GENÉTICOS E EXPRESSÃO DE CITOCINAS EM MULHERES ATENDIDAS NO MUNICÍPIO DE VITÓRIA DA CONQUISTA - BA

Dissertação apresentada ao Programa de Pós-Graduação em Microbiologia do Instituto de Ciências Biomédicas da Universidade de São Paulo, para obtenção do Título de Mestre em Ciências.

Área de Concentração: Microbiologia

Orientador: Prof. Dr. Jorge Timenetsky

Versão original 
DADOS DE CATALOGAÇÃO NA PUBLICAÇÃO (CIP)

Serviço de Biblioteca e Informação Biomédica do

Instituto de Ciências Biomédicas da Universidade de São Paulo

(c) reprodução total

Lobão, Tássia Neves.

Detecção de Ureaplasma urealyticum e U. parvum no trato urogenital e sua relação com poliformismos genéticos e expressão de citocinas em mulheres atendidas no município de Vitória da Conquista-BA / Tássia Neves Lobão. -- São Paulo, 2013.

Orientador: Prof. Dr. Jorge Timenetsky.

Dissertação (Mestrado) - Universidade de São Paulo. Instituto de Ciências Biomédicas. Departamento de Microbiologia. Área de concentração: Microbiologia. Linha de pesquisa: Biologia e distribuição de micoplasmas em humanos, animais e culturas celulares.

Versão do título para o inglês: Detection of Ureaplasma urealyticum and $U$. parvum in the urogenital tract and its relationship to genetc polymorphisms and expression of cytokines in women physical examination in Vitória da Conquista-BA.

$\begin{array}{llll}\text { 1. Ureaplasma urealyticum 2. Ureaplasma parvum } & \text { 3. Infecção }\end{array}$ urogenital 4. Poliformismo genético I. Timenetsky, Prof. Dr. Jorge II. Universidade de São Paulo. Instituto de Ciências Biomédicas. Programa de Pós-Graduação em Microbiologia III. Título. 
Candidato(a):

Título da Dissertação:

Orientador(a):
Tássia Neves Lobão.

Detecção de Ureaplasma urealyticum e U. parvum no trato urogenital e sua relação com poliformismos genéticos e expressão de citocinas em mulheres atendidas no município de Vitória da Conquista-BA.

A Comissão Julgadora dos trabalhos de Defesa da Dissertação de Mestrado, em sessão pública realizada a considerou
( ) Aprovado(a)
( ) Reprovado(a)

Examinador(a): Assinatura:

Nome:

Instituição:

Examinador(a): Assinatura:

Nome:

Instituição:

Presidente:

Assinatura:

Nome:

Instituição: 


\section{PARECER 1015/CEP}

A Comissão de Ética em Pesquisas com Seres Humanos do ICB, na sessão realizada no dia 21.09.2011, APROVOU o projeto intitulado: "Deteç̧ăo de ureaplasmas no trato urogenital feminino e a sua relação com polimorfismos genéticos e expressão de citocinas em mulheres atendidas no municipio de Vitória da Conquista-BA" sob responsabilidade de execução dos autores Prof. Dr. JoRge TImenetsty e a aluna TÁssia Neves Lobão.

Cabc os pesquisadores executantes elaborarem e apresentar a este Comitê, relatórios anuais (parciais ou final), de acordo com a resoluçäo 196/06 do Conselho Nacional da Saude, item IX. 2 ketrac:

() primciru relatório deverá ser encaminhado à Secretaria deste CEP em

21.09 .2012 .

Atenciosamente.

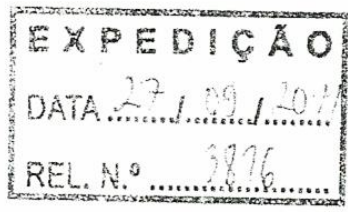

Comissäo de Ética em Pesquisa com Seres Humanos do Instituto de Ciências Biomédicas / USP Aprovada pela Comıssäo Nacional de Ėtica em Pesquisa - CONEP, em 10 de fevereiro de 1998 
Aos meus pais, pelo amor, dedicação, apoio e ajuda incondicional em todos os momentos. Minha eterna gratidão e admiração. 


\section{AGRADECIMENTO ESPECIAL}

A Fundação de Amparo à Pesquisa do Estado de São Paulo (FAPESP) pelo apoio financeiro, sem o qual este estudo não seria realizado. 


\section{AGRADECIMENTOS}

À Deus, minha fortaleza.

Ao meu orientador, Prof. Dr. Jorge Timenetsky, por toda ajuda dispensada à realização deste trabalho, pelo apoio, motivação. Obrigada por investir neste projeto, por confiar na minha capacidade de exercê-lo.

Ao meu co-orientador, Prof. Dr. Lucas Miranda Marques, pelo apoio e dedicação desde o tempo de iniciação científica no Laboratório de Microbiologia da Universidade Federal da Bahia (IMS/CAT), por acreditar e me ajudar a chegar até aqui. E a sua família que me acolheram no momento mais importante desta caminhada.

À CAPES, pelo mestrado.

Aos meus pais, Luís e Nailda, e ao meu irmão Bruno, por todo amor, confiança e apoio na vinda para São Paulo. Pai, obrigada por me ensinar a lutar pela vida e por ser meu exemplo de força. Mãe, obrigada pelo amor incondicional e por me ensinar a ser perseverante. Amo muito vocês!

À toda minha família, por todo amor que me dedicam e pelo incentivo.

Ao meu namorado Arlei, pelo amor, apoio, paciência, incentivo e por me ajudar a dar risada quando o que eu mais queria era chorar.

Aos meus sogros, Augusto e Rita, por todo carinho e confiança, aos meus cunhados Airan, Poliana, Ricardo, Sérgio e Wallace pela amizade, incentivo e amor. Obrigada por me acolherem com tanto amor nessa família maravilhosa.

À Guilherme Barreto Campos, por compartilhar todos os momentos deste trabalho, por sua competência profissional, e por sua amizade, e por nunca desistir de fazer o melhor.

À Aricelma Pinheiro de França (Celminha), por todo ensinamento e apoio técnico para execução deste trabalho. Pela relação de amizade e carinho que cultivamos, por todas as horas de conversas, desabafos e risadas. Você foi essencial!

Aos amigos do laboratório, Guilherme, Aline, Verena, Lucas, Carol, Denise, Angelita, Yaima, Carlos e Ana, pela ajuda e companheirismo.

À Maria Jacinta de Faria e ao Prof. Dr. Nilton Lincopan, pela amizade, conhecimentos divididos e incentivos constantes. 
À Profa. Ms. Lucineide Santos Silva, Profa. Dra. Tiana Baqueira e ao Prof. Dr. Djanilson Barbosa, pelas suas orientações e sugestões na elaboração deste trabalho.

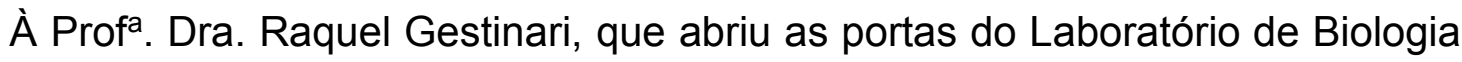
Celular e Molecular da Universidade Federal da Bahia (IMS/CAT).

Aos alunos da Universidade Federal da Bahia, Fernanda Teixeira pelo auxílio na técnica de MS-PCR, pela paciência e amizade, e Nathan Selis pela ajuda na época das coletas.

À Profa ${ }^{a}$. Dra. Joanne Messick por abrir as portas do Laboratório de Patobiologia Veterinária da Purdue University (Estados Unidos) para realização do sequenciamento.

Ao Prof. Dr. Jorge Luiz Mello Sampaio, da Faculdade de Ciências Farmacêuticas da Universidade de São Paulo, pelo auxílio ao nos ceder amostras clínicas.

Aos funcionários da Sala de Esterilização do ICB II, Carolina Bertelli Ferreira, Elaine dos Santos, Elaine Costa e José dos Santos Filho, e aos técnicos e auxiliares Alexandre Alves, Andemir da Silva (Mineiro) e Carlos Augusto da Silva. Obrigada pelo carinho e amizade!

Aos funcionários, Bruno, Elizabete, Gisele e Naide da secretaria do departamento de microbiologia do ICB II.

Aos funcionários da biblioteca do Instituto de Ciências Biomédicas pelo auxílio prestado na preparação deste trabalho.

À todos os amigos do Laboratório de Microbiologia da Universidade Federal da Bahia (IMS/CAT) (Aline, Beatriz, Clarissa, Daniel, Danilo, Eliana, Ewerton, Guilherme, Hellen, Ícaro, Igor, Izadora, Jéssica, Karol, Laiziane, Mariângela, Maysa, Nathan, Pollianna, Simone, Suerda, Suzelle, Suzi, Tâmara, Thiago e Verena) por toda ajuda neste trabalho, pelo carinho, conhecimento e momentos compartilhados.

À todas a mulheres que participaram do estudo, pela confiança em compartilhar suas histórias e dúvidas, e aos profissionais das Unidades de Saúde. Muito obrigada.

Às minhas queridas companheiras de casa, Verena, Gisela e Rosana. Obrigada pelo carinho, pelos momentos felizes, conversas e paciência e tolerância nos momentos de estresse. Véu, Obrigada pelo companheirismo e amizade. 
Aos amigos queridos, Alicia Carolina, Ana Cristina Vitelleschi, Arielly Filadelfo, Camila Bispo, Danielle Borges, Danyelle Machado, Dannieli Espírito Santo, Deusdete Dias, Felipe Nascimento, Ioná Andrade, Janiere Santana, Jussara Viana, Luciana Brasil, Luciana Curi, Luciane Azevedo, Liz Cavalcante, Maiara Ribeiro, Mariana Cardoso, Priscila Chéquer, Poliane Cangussú, Renata Neves, Saima Pool, Silvia Alessandra, Sumaia Nader, Tassio Maia, Verena Macêdo e Zan Emir. Obrigada pela amizade e por todos os momentos vividos. Amo todos vocês!

A todos, aqui não mencionados, que de alguma forma viabilizaram o desenvolvimento deste trabalho. 
"Talvez não tenha conseguido fazer o melhor, mas lutei para que o melhor fosse feito. Não sou o que deveria ser, mas Graças a Deus, não sou o que era antes". 


\section{RESUMO}

LOBAO, T. N. Detecção de Ureaplasma urealyticum e U. parvum no trato urogenital e sua relação com polimorfismos genéticos e expressão de citocinas em mulheres atendidas no município de Vitória da Conquista, BA. 2013. 146 f. Dissertação (Mestrado em Microbiologia) - Instituto de Ciências Biomédicas, Universidade de São Paulo, São Paulo, 2013.

Ureaplasmas são bactérias comumente isoladas do trato urogenital humano. Entretanto, Ureaplasma urealyticum e $U$. parvum também foram associados a infecções genitais, dificultando a compreensão do papel destes microrganismos. Alguns estudos relacionam os polimorfismos de citocinas com a presença de ureaplasmas e as vaginoses bacterianas. Neste contexto, o objetivo do estudo foi detectar a presença de ureaplasmas em mulheres sexualmente ativas do semiárido baiano e relacionar aos aspectos demográficos e de saúde sexual, com polimorfismo das citocinas IL-6 e IL-1 $\beta$. Foram incluídas amostras de swab vaginal e sangue periférico de 302 mulheres atendidas em Unidades de Saúde da Família em Vitória da Conquista, Bahia. A frequência de detecção por PCR convencional foi de $76,2 \%$ para Mollicutes, $7,0 \%$ para U. urealyticum e $52,0 \%$ para U. parvum. Na qPCR foi encontrada frequência de $16,6 \%$ para $U$. urealyticum e $60,6 \% U$. parvum, sendo a presença destes microrganismos associada significativamente a sinais e sintomas de infecção genital. As amostras de U. parvum foram subtipadas e os sorotipos $6 \mathrm{e}$ $3 / 14$ foram os mais frequentes, seguidos do sorotipo 1. A frequência encontrada para Trichomonas vaginalis, Neisseria gonorrhoeae, Gardnerella vaginalis e Chlamydia trachomatis foi de $3,0 \%, 21,5 \%, 42,4 \%$ e $1,7 \%$, respectivamente. Ainda foi detectada co-infecção destes microrganismos com ureaplasmas. $\mathrm{Na}$ análise de polimorfismo genético para IL-6, o genótipo GG foi o mais frequente e para o polimorfismo de IL-1 $\beta$, o genótipo CC apresentou maior prevalência. Não foi observado diferenças entre os níveis das citocinas no plasma sanguíneo entre mulheres do grupo caso e controle. Maiores níveis de IL-1 $\beta$ foram associados a mulheres do grupo controle colonizadas por $U$. urealyticum, e maiores níveis de IL-6 associados a mulheres que não apresentam U. parvum.

Palavras-chave: Ureaplasma urealyticum. Ureaplasma parvum. Infecção urogenital. Polimorfismo genético. 


\begin{abstract}
LOBAO, T. N. Detection of Ureaplasma urealyticum and $U$. parvum in the urogenital tract and its relationship to genetic polymorphisms and expression of cytokines in women physical examination in Vitória da Conquista, BA. 2013. 146 p. Masters thesis (Microbiology) - Instituto de Ciências Biomédicas, Universidade De São Paulo, São Paulo, 2013.

Ureaplasmas are bacteria commonly isolated from the human urogenital tract. However, Ureaplasma urealyticum and $U$. parvum were also associated with genital infections, making it difficult to understand the role of these microorganisms. Some studies relate the cytokine polymorphisms with the presence of ureaplasmas and bacterial vaginosis. In this context, the purpose of this study was to detect the presence of ureaplasmas in sexually active women of the semiarid region of Bahia and relate to demographic and sexual health, and polymorphism of cytokines IL-6 and IL-1 $1 \beta$. It was included samples of vaginal swab and peripheral blood of 302 women examined at the Family Health Units in Vitória da Conquista, Bahia. The frequency of detection by conventional PCR was $76.2 \%$ for Mollicutes, $7.0 \%$ to $U$. urealyticum and $52.0 \%$ for $U$. parvum. In the qPCR the frequency found was of $16.6 \%$ to $U$. urealyticum and $60.6 \% \quad U$. parvum and the presence of these microorganisms was significantly associated with signs and symptoms of genital infection. Samples of $U$. parvum were subtyped and serotypes 6 and 3/14 were the most frequent, followed by serotype 1. The frequency found for Trichomonas vaginalis, Neisseria gonorrhoeae, Gardnerella vaginalis and Chlamydia trachomatis was $3.0 \%, 21.5 \%, 42.4 \%$ and $1.7 \%$, respectively. It was also found co-infection of these microorganisms with ureaplasmas. In the analysis of genetic polymorphism for IL-6, GG genotype was the most frequent and the polymorphism of IL-1 $1 \beta$, the CC genotype presented higher prevalence. No differences were observed between the levels of cytokines in the blood plasma of women in the case group and control. Higher levels of $\mathrm{IL}-1 \beta$ were associated with control women colonized by $U$. urealyticum, increased levels of IL-6 associated with women who did not exhibit $U$. parvum.
\end{abstract}

Keywords: Ureaplasma urealyticum. Ureaplasma parvum. Urogenital infection. Genetic polymorphisms. 


\section{LISTA DE ABREVIATURAS E SIGLAS}

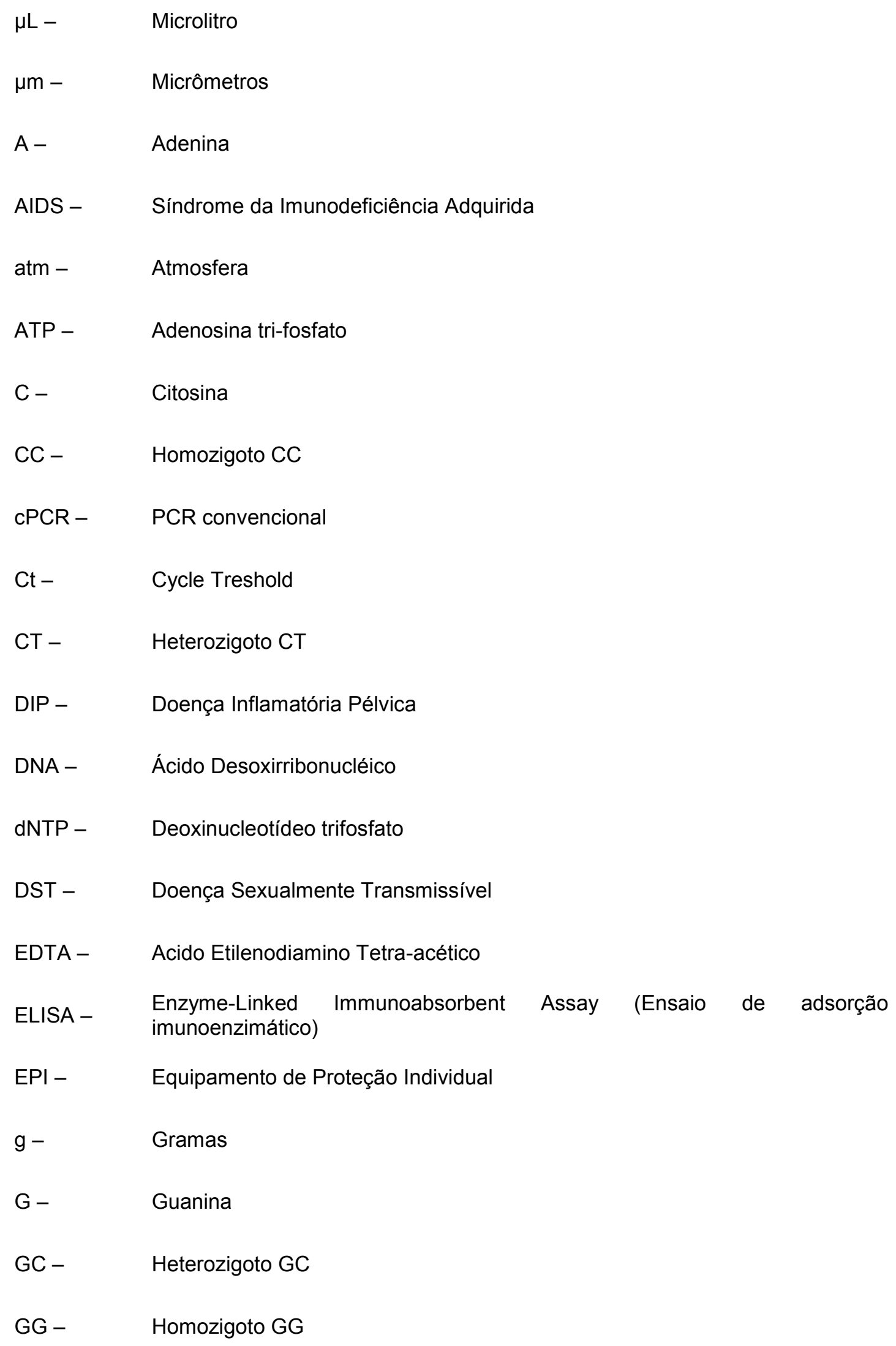




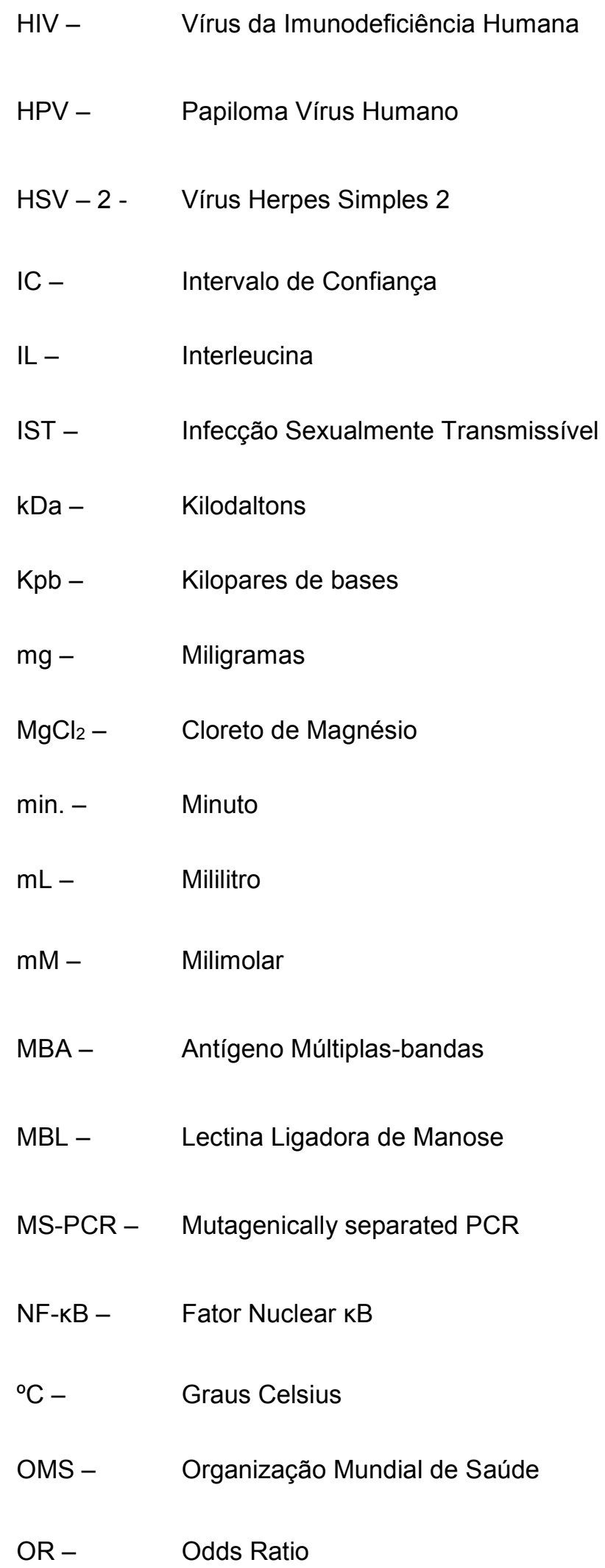




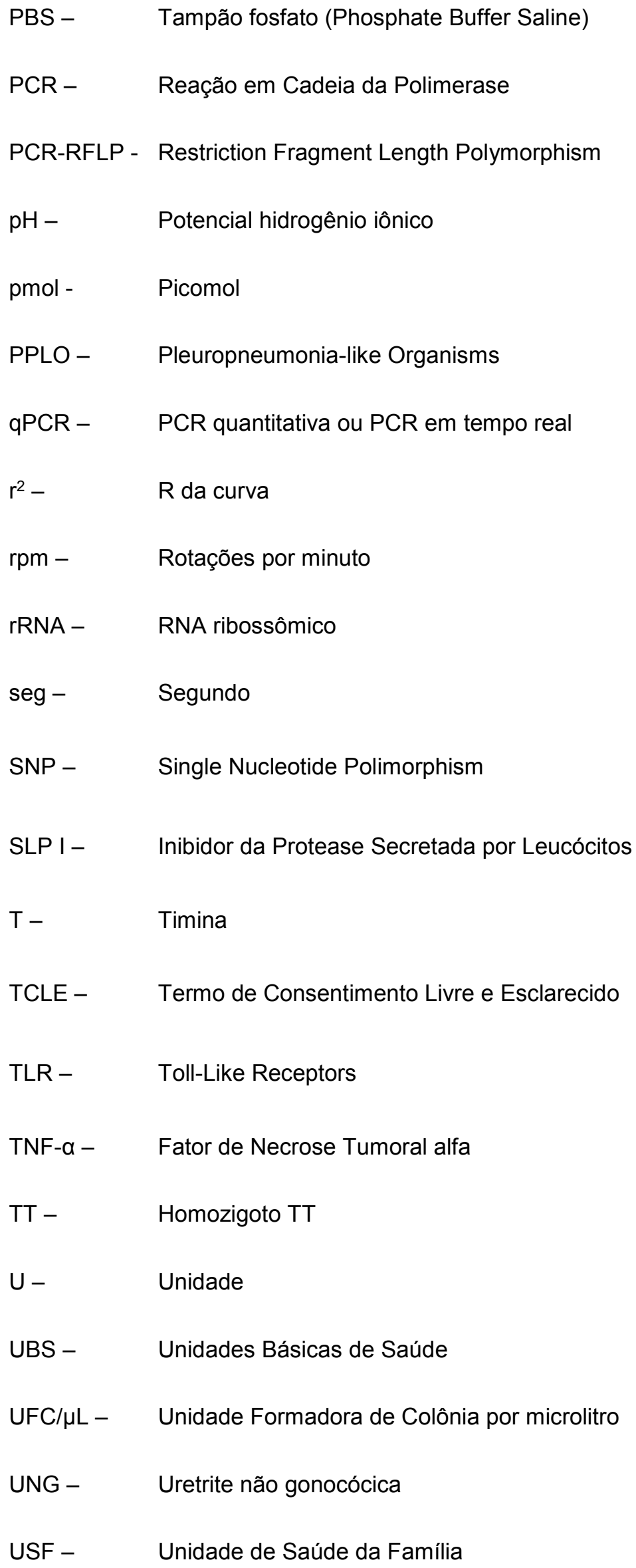




$\begin{array}{ll}\text { VB - } & \text { Vaginose Bacteriana } \\ X- & \text { Vezes } \\ \alpha- & \text { Alfa } \\ \beta- & \text { Beta }\end{array}$




\section{LISTA DE FIGURAS}

Figura 1 - Colônia de M. hominis em meio SP4 com sua característica forma de "ovo frito" (aumento 40X).

Figura 2 - Gráficos gerados a partir da reação de PCR em tempo real para determinação da curva padrão utilizada nos testes para a espécie $U$. urealyticum.

Figura 3 - Eletroforese em gel de agarose dos produtos da PCR utilizando "primers" genéricos GPO3 e MGSO para detecção de Mollicutes..

Figura 4 -

Eletroforese em gel de agarose dos produtos amplificados na PCR utilizando "primers" MS170 e UMA263 para detecção de U. urealyticum........ Eletroforese em gel de agarose dos produtos amplificados na PCR

Figura 5 utilizando "primers" UMS57 e UMA222 para detecção de U. parvum.

Figura 6 Quantificação por qPCR, de $U$. urealyticum e $U$. parvum (UFC/ $\mu \mathrm{L}$ ) a partir das amostras de swab vaginal, nos grupos caso e controle.

Eletroforese em gel de agarose dos produtos da MS-PCR evidenciando três

Figura 7 - perfis de polimorfismos genéticos da região gênica onde ocorre a mutação pontual na citocina IL-6

Figura 8 -

Eletroforese em gel de agarose dos produtos amplificados na PCR, da região gênica onde ocorre a mutação pontual, utilizando "primers" P1 e P2 com DNA das amostras de sangue coletadas das mulheres......

Figura 9 - Eletroforese em gel de agarose dos produtos da PCR-RFLP evidenciando três perfis de polimorfismos genéticos da região gênica onde ocorre a mutação pontual na citocina IL-1 $\beta$.

Figura 10 - Eletroesferograma parcial da reação de sequenciamento dos fragmentos dos genes IL-6 e IL-1 $\beta$ evidenciando as regiões dos polimorfismos c- 174 C>G e c- $+3954 \mathrm{C}>\mathrm{T}$.

Figura 11 - Quantificação de IL-1ß e IL-6 (pg/mL) no plasma sanguíneo, por meio do ELISA, nos grupos caso e controle de mulheres atendidas em unidades de saúde de Vitória da Conquista - BA, 2011.

Figura 12 - Relação entre a infecção vaginal por $U$. urealyticum, e as concentrações das citocinas IL-1 $\beta$ e IL-6 no plasma sanguíneo, por meio do ELISA, entre mulheres atendidas em unidades de saúde de Vitória da Conquista - BA, 2011.

Figura 13 - Relação entre a infecção vaginal por $U$. parvum, e as concentrações das citocinas IL-1 $\beta$ e IL-6 no plasma sanguíneo, por meio do ELISA, entre mulheres atendidas em unidades de saúde de Vitória da Conquista - BA, 2011.

Figura 14 - Quantificação de IL-1ß e IL-6 no plasma sanguíneo nos grupos caso e controle e sua relação com o perfil genotípico dos polimorfismos associados às citocinas encontrados em mulheres atendidas em unidades de saúde de Vitória da Conquista - BA, 2011. 


\section{LISTA DE QUADROS}

Quadro 1 - Sequências dos iniciadores utilizados para amplificação do gene 16S rRNA para Mollicutes e peso molecular do produto amplificado.

Quadro 2 - Sequências dos iniciadores utilizados para amplificação do gene 16S rRNA para $U$. urealyticum e peso molecular do produto amplificado

Quadro 3 - Sequencias dos iniciadores utilizados para amplificação do gene $16 \mathrm{~S}$ rRNA para U. parvum e peso molecular do produto amplificado.

Quadro 4 - Sequências dos iniciadores utilizados para amplificação do gene 16S rRNA para Sorotipos do U. parvum e peso molecular do produto amplificado.

Quadro 5Sequências dos iniciadores utilizados para amplificação de região gênica específica para detecção de Neisseria gonorrhoeae....

Quadro 6 - Sequências dos iniciadores utilizados para amplificação de região gênica específica para detecção de Gardnerella vaginalis.

Quadro 7 - Sequências dos iniciadores utilizados para amplificação de região gênica específica para detecção de Trichomonas vaginalis.

Quadro 8 - Sequências dos iniciadores utilizados para amplificação de região gênica específica para detecção de Chlamydia trachomatis.

Quadro 9 - Sequências dos iniciadores utilizados para detecção de polimorfismo monogenético na região -174 do cromossomo que codifica a IL-6 e peso molecular do produto amplificado.

Quadro 10 - Sequências dos iniciadores utilizados para amplificação de região gênica específica em que ocorre mutação monogênica para IL-1ß e peso molecular do produto amplificado 


\section{LISTA DE TABELAS}

Tabela 1 - Perfil de detecção de Mollicutes, U. urealyticum e $U$. parvum, por meio da PCR convencional, em amostras de swab vaginal de mulheres atendidas em Unidades de Saúde de Vitória da Conquista - BA, $2011 .$.

Tabela 2 - Perfil de detecção dos sorotipos de U. parvum, por meio da PCR convencional, em amostras de swab vaginal de mulheres atendidas em Unidades de Saúde de Vitória da Conquista - BA, 2011......

Tabela 3 - $\quad$ Perfil de detecção de U. urealyticum e U. parvum, por meio da qPCR em amostras de swab vaginal de mulheres atendidas em Unidades de Saúde de Vitória da Conquista - BA, 2011......

Tabela $4-$ Perfil de detecção dos microrganismos Trichomonas vaginalis, Neisseria gonorrhoeae, Gardnerella vaginalis, e Chlamydia trachomatis em amostras de swab vaginal testadas por meio da PCR convencional, em mulheres atendidas em Unidades de Saúde de Vitória da Conquista - Ba, 2011.

Tabela 5 Perfil das mulheres com resultado de PCR e qPCR positivo para Mollicutes, $U$. urealyticum e $U$. parvum, atendidas em unidades de saúde de Vitória da Conquista - BA, 2011.

Tabela $6-$ Detecção de Mollicutes por meio da PCR convencional em amostras de swab vaginal e sua relação com o perfil clínico-demográfico da população de mulheres atendidas em unidades de saúde de Vitória da Conquista - BA, 2011.

Tabela 7 -

Detecção de $U$. urealyticum por meio da PCR convencional, em amostras de swab vaginal, e sua relação com o perfil das mulheres atendidas em unidades de saúde de Vitória da Conquista - BA, 2011.

Detecção de $U$. urealyticum por meio da qPCR, em amostras de swab vaginal,

Tabela 8 e sua relação com o perfil das mulheres atendidas em unidades de saúde de Vitória da Conquista - BA, 2011

Tabela $9-$ Detecção de U. parvum por meio da PCR convencional em amostras de swab vaginal, e sua relação com o perfil das mulheres atendidas em unidades de saúde de Vitória da Conquista - BA, 2011.

Tabela $10-$ Detecção de $U$. parvum Sorotipo 1 por meio da PCR em amostras de swab vaginal, e sua relação com o perfil das mulheres atendidas em unidades de saúde de Vitória da Conquista - BA, 2011.

Tabela $11-$ Detecção de U. parvum Sorotipo 3/14 por meio da PCR em amostras de swab vaginal, e sua relação com o perfil das mulheres atendidas em unidades de saúde de Vitória da Conquista - BA, 2011.

Tabela 12 - Detecção de U. parvum Sorotipo 6 por meio da PCR em amostras de swab vaginal, e sua relação com o perfil das mulheres atendidas em unidades de saúde de Vitória da Conquista - BA, 2011.

Tabela $13-$ Detecção de U. parvum por meio da qPCR, em amostras de swab vaginal, e sua relação com o perfil das mulheres atendidas em unidades de saúde de Vitória da Conquista - BA, 2011.

Tabela $14-$ Perfil das mulheres com e sem sinais e/ou sintomas em relação à presença de Mollicutes, $U$. urealyticum e $U$. parvum detectados por PCR convencional e qPCR em amostras de swab vaginal de mulheres atendidas em unidades de saúde de Vitória da Conquista - BA, 2011......

Perfil clínico-demográfico das mulheres com e sem sinais e/ou sintomas de

Tabela 15 - infecção urogenital atendidas em unidades de saúde de Vitória da Conquista BA, 2011...

Tabela 16 - Análise multivariada dos fatores de risco para detecção vaginal de Mollicutes, $U$. urealyticum e $U$. parvum em mulheres atendidas em Unidades de saúde de Vitória da Conquista - BA.

Tabela 17 - Análise multivariada dos fatores de risco para detecção vaginal dos sorotipos $U$. parvum, G. vaginalis, N. gonorrhoeae e sinais e sintomas em mulheres atendidas em Unidades de saúde de Vitória da Conquista - BA. 
Tabela 18 - Frequência dos genótipos das interleucinas IL-6 e IL-1 $\beta$ para seus respectivos polimorfismos encontrados em amostras de sangue de mulheres atendidas em 98 unidades de saúde de Vitória da Conquista - BA, 2011

Tabela 19 - Perfil genotípico das interleucinas (IL-6 e IL-1ß) e sua relação com a detecção de U. urealyticum por meio da PCR convencional e PCR em tempo real, em amostras de DNA de mulheres atendidas em unidades de saúde de Vitória da Conquista - BA, 2011

Tabela 20 - Perfil genotípico das interleucinas (IL-6 e IL-1ß) e sua relação com a detecção de U. parvum por meio da PCR convencional e PCR em tempo real, em amostras de DNA de mulheres atendidas em unidades de saúde de Vitória da Conquista - BA, 2011.

Tabela 21 - Perfil genotípico das interleucinas (IL-6 e IL-1ß) e sua relação com a detecção de $T$. vaginalis e $N$. gonorrhoeae por meio da PCR convencional em amostras de DNA de mulheres atendidas em unidades de saúde de Vitória da Conquista - BA, 2011

Tabela 22 - Perfil genotípico das interleucinas (IL-6 e IL-1ß) e sua relação com a detecção de $G$. vaginalis e $C$. trachomatis por meio da PCR convencional em amostras de DNA de mulheres atendidas em unidades de saúde de Vitória da Conquista - BA, 2011

Tabela 23 - Perfil genotípico das interleucinas (IL-6 e IL-1 $\beta$ ) e sua relação com a presença de sinais e/ou sintomas clínicos reportados ou evidenciados em mulheres atendidas em unidades de saúde de Vitória da Conquista - BA, 2011. 


\section{SUMÁRIO}

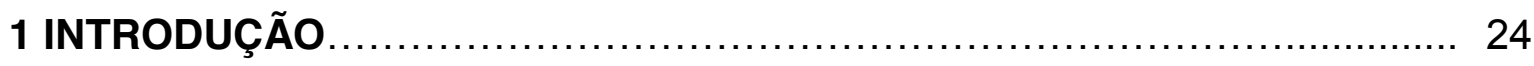

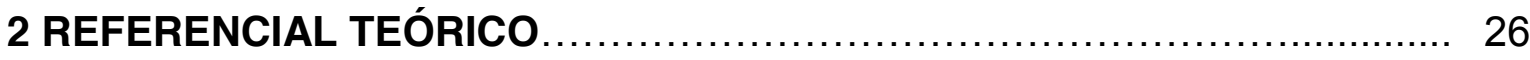

2.1 Saúde Pública e Infecções Sexualmente Transmissíveis.................... 26

2.2 Características gerais das Vaginoses Bacterianas ........................ 27

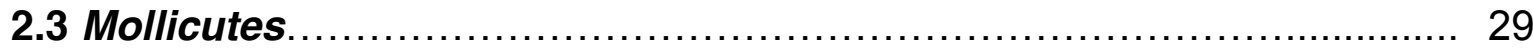

2.3.1 Características gerais dos Mollicutes........................................ 29

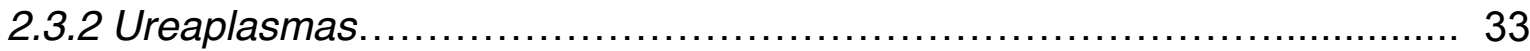

2.4 Outros microrganismos de importância ginecológica....................... 35

2.4.1 Chlamydia trachomatis........................................................ 35

2.4.2 Gardnerella vaginalis..................................................... 36

2.4.3 Neisseria gonorrhoeae....................................................... 38

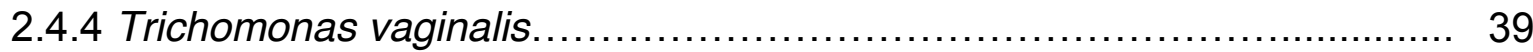

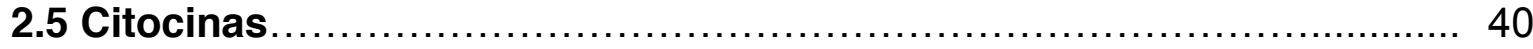

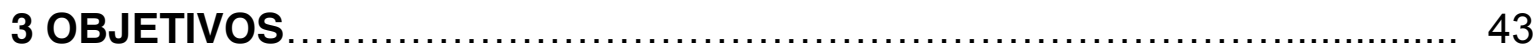

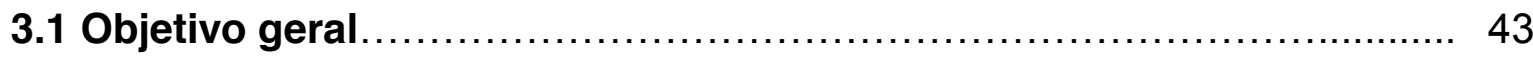

3.2 Objetivos específicos........................................................ 43

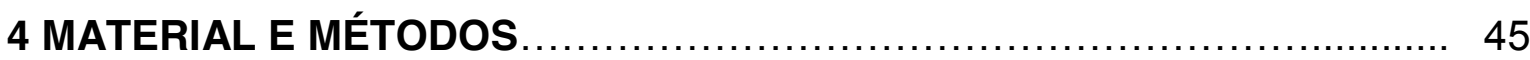

4.1 População do estudo................................................................. 45

4.2 Descrição da Região do estudo ............................................ 45

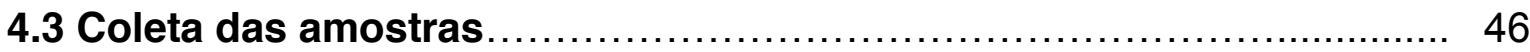

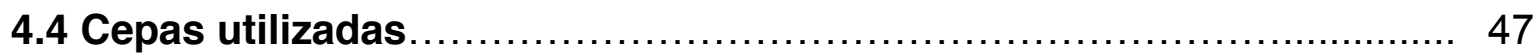

4.5 Extração de DNA das amostras de swab vaginal........................... 47

4.6 Padronização da Reação em Cadeia da Polimerase (PCR) convencional

4.6.1 PCR para deteç̧ão de Mollicutes.............................................. 48

4.6.2 PCR para deteç̧ão de U. urealyticum............................................ 49

4.6.3 PCR para detecção de U. parvum................................................. 49

4.6.4 PCR para deteç̧ão dos sorotipos da espécie U. parvum...................... 50

4.6.5 PCR para deteç̧ão de Neisseria gonorrheae.................................... 51

4.6.6 PCR para detecção de Gardnerella vaginalis................................. 52

4.6.7 PCR para detecção de Trichomonas vaginalis................................... 53

4.6.8 PCR para detecção de Chlamydia trachomatis.................................. 53 


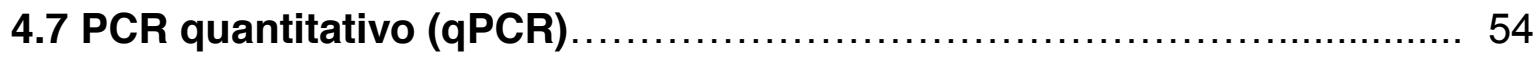

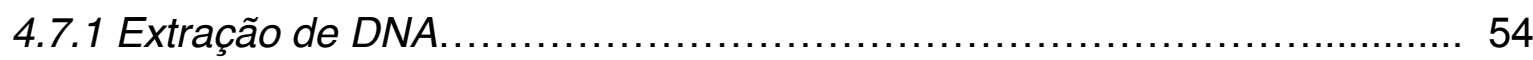

4.7.2 qPCR para deteç̧ão de U. urealyticum........................................ 54

4.7.3 qPCR para deteç̧ão de U. parvum................................................. 55

4.7.4 Análise dos dados da qPCR ................................................ 55

4.8 Polimorfismo de citocinas ................................................... 56

4.8.1 Extração de DNA das amostras de sangue..................................... 56

4.8.2 MS-PCR para detecção do polimorfismo $c-174 \mathrm{G}>\mathrm{C}$ no gene IL-6............ 56

4.8.3 PCR RFLP para detecção do polimorfismo c-+3954 C>T no gene IL-1 $\beta \ldots 57$

4.8.4 Confirmação do polimorfismo genético dos genes IL-6 e IL-1ß por

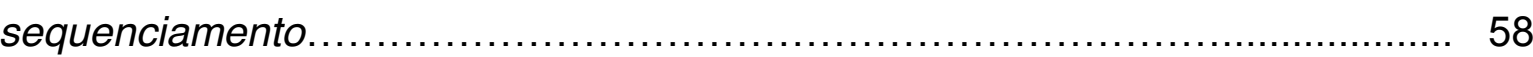

4.9 Dosagem das citocinas IL-6 e IL-1 $\beta$ no soro.................................. 59

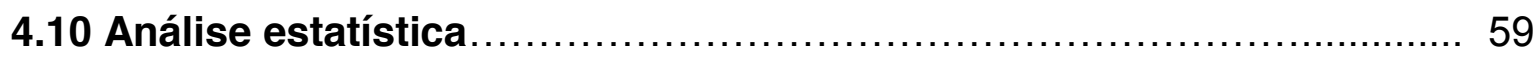

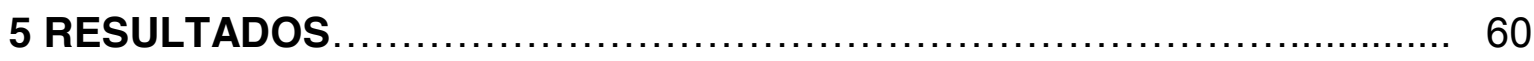

5.1 PCR para a detecção de Ureaplasma ......................................... 60

5.2 PCR para detecção dos sorotipos de U. parvum .............................. 62

5.3 qPCR para deteç̧ão de Ureaplasmas ........................................ 63

5.4 PCR para detecção de outros microrganismos de importância ginecológica.

5.5 Caracterização do perfil demográfico e da saúde sexual das

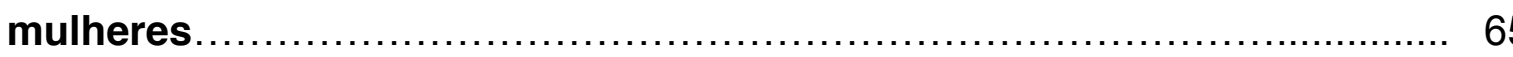

5.5.1 Perfil das mulheres com a presença de Mollicutes, $U$. urealyticum e $U$. parvum nas amostras de swab vaginal.................................................... 65

5.5.2 Perfil das mulheres que apresentaram Mollicutes nas amostras de swab vaginal.

5.5.3 Perfil das mulheres que apresentaram $U$. urealyticum na $P C R$

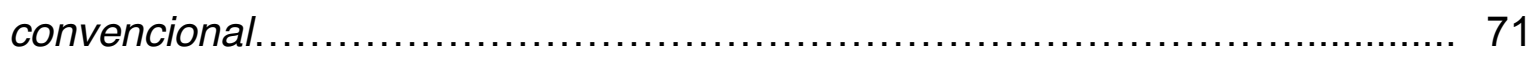

5.5.4 Perfil das mulheres que apresentaram U. urealyticum na qPCR............. 71

5.5.5 Perfil das mulheres que apresentaram U. parvum na PCR convencional.. 76 5.5.6 Perfil das mulheres que apresentaram os sorotipos de U. parvum na

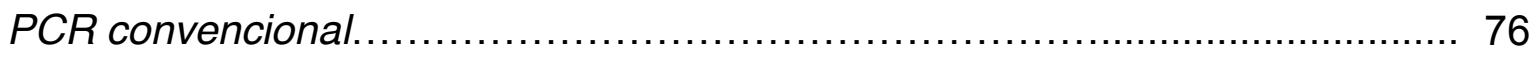

5.5.7 Perfil das mulheres que apresentaram U. parvum na qPCR.................. 85 
5.5.8 Perfil das mulheres com ou sem sinais elou sintomas em relação à presença $U$. urealyticum e $U$. parvum detectados por PCR convencional e qPCR.

5.5.9 Perfil clínico-demográfico das mulheres com e sem sinais e/ou sintomas.

5.5.10 Análise multivariada da detecção de Mollicutes, U. urealyticum e U. parvum, e sinais e sintomas nas mulheres atendidas.

5.6 Análise dos polimorfismos genômico das citocinas

5.6.1 Detecção de polimorfismo genético da Interleucina-6 (IL-6) por meio da MS-PCR.

5.6.2 Detecção de polimorfismo genético da Interleucina $1 \beta$ (IL-1ß) por meio da PCR RFLP

5.6.3 Perfil do polimorfismo genético das interleucinas (IL-1ß e IL-6) na população estudada e sua relação com a detecção dos diversos microrganismos.

5.6.4 Perfil genotípico das interleucinas (IL-1 $\beta$ e IL-6) na população estudada e sua relação com a presença ou ausência de sinais e sintomas relatados.......

5.7 Dosagem das citocinas no soro das mulheres analisadas

5.7.1 Análise das citocinas em relação aos dados clínicos e detecção de ureaplasmas.

5.7.2 Relação entre a quantificação das citocinas IL-1ß e IL-6 e a distribuição genotípica dos polimorfismos associados.

6 DISCUSSÃO

7 CONCLUSOES

REFERÊNCIAS 


\section{INTRODUÇÃO}

O termo micoplasma, informalmente, designa os microrganismos da Classe Mollicutes, $($ Mollis = mole; cútis $=$ pele $)$ composta por cinco ordens, seis famílias e 14 gêneros. Com aproximadamente 200 espécies, os molicutes estão distribuídos entre plantas, insetos e animais incluindo-se o homem (RAZIN, 1992). Estes se diferenciam de outras bactérias principalmente pelo seu pequeno tamanho e ausência de parede celular, além de algumas espécies apresentarem o menor genoma entre os procariotos, tendo como consequencia um metabolismo reduzido. Em geral, aproximam-se das dimensões dos maiores vírus $(0,2$ a 0,4 $\mu \mathrm{m})$ (MILES; NICHOLAS, 1998).

Diversos molicutes são apontados como constituintes da microbiota de indivíduos saudáveis. Entretanto, alguns também foram associados a infecções urogenitais, dificultando a compreensão do papel destas espécies (KRAUSE; TAYLOR-ROBINSON, 1992). Nos gêneros Mycoplasma, Ureaplasma e Acholeplasma encontram-se as espécies que habitam os animais como comensais, saprófitos ou patógenos (RAZIN; BARILE, 1985).

Espécies de Ureaplasma colonizam o trato urogenital de indivíduos saudáveis, no entanto, eles foram incluídos entre os agentes infecciosos causadores de doenças urogenitais em humanos (KRAUSE, 1992). Mesmo assim, a infecção e a distribuição destes microrganismos em diversos grupos populacionais ainda é pouco conhecida (CORDOVA; CUNHA, 2002). A infecção genital por micoplasma é de difícil diagnóstico clínico, uma vez que não existe sintoma característico e, geralmente esses microrganismos estão envolvidos com patologias multicausais (SIMOES, 1999).

Os ureaplasmas e outros molicutes estão entre os menores organismos capazes de auto-replicação. Os molicutes foram descritos inicialmente em 1954, compreendendo os membros da família Mycoplasmataceae, sendo o gênero Ureaplasma estabelecido em 1974. Os ureaplasmas têm a característica de hidrolisar a uréia utilizando-a como substrato metabólico para geração de ATP. Este gênero atualmente possui duas espécies de origem humana e cinco de origem animal (DOMINGUES, 2005; PARALANOV et al., 2012).

As espécies $U$. urealyticum e $U$. parvum estão associadas a quadros de uretrite não-gonocócica e não-clamidial (ONDONDO et al., 2010), doença 
inflamatória pélvica (DIP), endometrite e a condições que podem afetar a gestação, o desenvolvimento do feto e do recém-nascido. Contribuem para o trabalho de parto prematuro, corioamnionite espontânea, aborto espontâneo, prematuridade e baixo peso ao nascer. O recém-nascido exposto pode desenvolver pneumonia, meningite, bacteremia, abscessos e displasia broncopulmonar (SUNG, 2010; XIAO et al., 2010).

A resposta imunológica mais comum durante infecção por ureaplasmas envolve a produção de citocinas pró-inflamatórias (IL-1 $\alpha$, IL-1 $1 \beta$, IL-6, IL-8 e TNF- $\alpha$ ), acompanhada por infiltrado de neutrófilos e macrófagos nos locais de infecção. Entretanto, as complexas interações entre ureaplasma e o hospedeiro que levam a simples colonização ou ao desenvolvimento de doenças são em grande parte desconhecidos (REYES et al., 2006).

Neste contexto, alguns estudos relacionam os polimorfismos de citocinas com a presença de microrganismos e as vaginoses bacterianas. Jeremias et al. (1999) associaram o polimorfismo do receptor da citocina IL-1 com a presença de $U$.

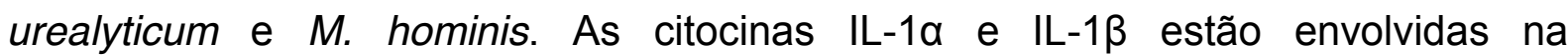
proliferação, diferenciação e apoptose celular. IL-1 $\beta$ é uma proteína extracelular secretada por vários tipos celulares como macrófagos, linfócitos $B$ e fribroblastos (DINRELLO, 1996). A IL-6 está envolvida na patogênese relacionada ao trabalho de parto prematuro, artrite reumatóide, psoríase, doença de Alzheimer e também a doença periodontal (MOREIRA; LIMA, 2007; TAYLOR et al., 2013; TERVONEN; RAUNIO, 2007; TREVILATTO; SCAREL-CAMINAGA, 2003).

A melhor compreensão da patogênese dos ureaplasmas e sua caracterização como agentes oportunistas têm aberto novas perspectivas na micoplasmologia humana. Apesar dos diversos esclarecimentos na biologia destas bactérias em humanos, existe pouco conhecimento no papel destas bactérias quando são comensais ou quando causam doenças (KRAUSE; TAYLOR-ROBINSON, 1992). Assim, é de extrema importância investigar a presença de $U$. urealyticum e $U$. parvum no trato urogenital feminino, e relacionar aos aspectos da saúde sexual e reprodutiva, que são essenciais na assistência à saúde da mulher. 


\section{REFERENCIAL TEÓRICO}

\subsection{Saúde Pública e Infecções Sexualmente Transmissíveis}

Mesmo com o desenvolvimento de novos métodos diagnósticos e novas terapêuticas, as infecções sexualmente transmissíveis (IST) estão entre os principais problemas de saúde pública no mundo, com grande impacto socioeconômico e psicológico nos indivíduos. Estas doenças constituem uma das cinco causas mais frequentes de busca por serviços de saúde em países em desenvolvimento (BRASIL 2008, 2011a).

Estimativas recentes apontam que casos de IST podem evoluir para doenças sintomáticas, como uretrites, cervicites, úlceras e verrugas genitais, ou permanecerem assintomáticas. $\mathrm{O}$ alto índice de automedicação torna o problema ainda maior, já que muitos dos casos não recebem orientação e tratamento adequados, tornando-se casos subclínicos, mantendo os hospedeiros com potencial de transmissão destes agentes (BRASIL, 2011b).

A Organização Mundial de Saúde (OMS) estima que 499 milhões de casos novos de IST curáveis (gonorréia, clamídia, sífilis, vaginose bacteriana e tricomoníase) ocorreram em 2008 no mundo (WHO, 2013). As IST, no mundo, têm significativa implicação na economia, principalmente nos países em desenvolvimento no qual respondem por $17 \%$ de perdas econômicas com o binômio saúde-doença (BRASIL, 2005, 2011a).

A OMS estima que no Brasil, as IST consideradas curáveis correspondem de 10 a 12 milhões de casos novos por ano. Aproximadamente 10,3 milhões de brasileiros já apresentaram algum sinal ou sintoma de IST. Diversos casos de IST não-curáveis (virais) também ocorrem anualmente, como, por exemplo, herpes genital (HSV-2), papilomavírus humano (HPV), hepatite B e HIV (DO VAL, 2012).

Mulheres com infecções não tratadas por gonorréia e/ou clamída podem desenvolver complicações como DIP, e destas, cerca de $25 \%$ poderão se tornar inférteis. Abortos espontâneos, natimortos, baixo peso ao nascer, infecção congênita e perinatal estão associados às IST não tratadas, em gestantes. Relatos de diversos países mostraram que pessoas com IST, mesmo com lesões não ulcerativas, apresentavam 3 a 10 vezes mais chance de se infectarem pelo vírus HIV (BRASIL, 2005). 
Apesar disso, as IST só voltaram a readquirir importância como problema de saúde pública após a epidemia de AIDS (Síndrome da Imunodeficiência Adquirida) (FLEMING; WASSERHEIT, 1999; ONOYA et al., 2012). O HIV está presente na secreção cérvico-vaginal numa frequência duas vezes maior entre mulheres com gonorréia, três vezes maior na presença de clamídia e quatro vezes maior se existe ulceração no colo uterino ou na vagina (GHYS et al., 1997).

$\mathrm{Na}$ maioria dos países, as listas de doenças de notificação compulsória incluem apenas algumas infecções genitais. No Brasil, as IST que fazem parte da lista nacional de agravos de notificação compulsória compreendem apenas os casos de AIDS, gestantes HIV positivas, crianças expostas ao HIV, gestantes com sífilis e crianças com sífilis congênita. Praticamente não existem dados precisos de incidência das IST em nível Nacional e a ausência de estudos de base populacional dificulta a visibilidade do problema e implantação de intervenções prioritárias, avaliação de sua efetividade e seu re-direcionamento (BRASIL 2008, 2006).

\subsection{Características gerais das Vaginoses Bacterianas}

As mulheres são biologicamente mais susceptíveis às IST, sendo a maioria assintomática. No mundo, uma das causas mais comuns de vaginite em mulheres sexualmente ativas durante a idade fértil, é a vaginose bacteriana (VB) (SALAH et al., 2013; TANAKA et al., 2007).

O ambiente vaginal é quantitativamente dominado por espécies de Lactobacillus produtores de peróxido de hidrogênio $\left(\mathrm{H}_{2} \mathrm{O}_{2}\right)$, sendo $\circ \mathrm{pH}<4,7$ considerado normal. Este conjunto tem sido consistentemente associado a gravidez saudável, ausência de sintomas vaginais anormais, e risco reduzido para a aquisição de vários patógenos sexualmente transmissíveis, incluindo o HIV (SPURBECK; ARVIDSON, 2008). A VB é uma síndrome inflamatória e recorrente do trato genital inferior feminino. É caracterizada pela alteração da microbiota vaginal em que os lactobacilos, normalmente predominantes, são substituídos por microrganismos diversos, com aumento das espécies de aeróbios facultativos e anaeróbios, como Gardnerella vaginalis, Mobiluncus sp, Bacteroides sp, Prevotella $\mathrm{sp}$, Peptostreptococcus sp, incluindo espécies de Mycoplasma sp. e Ureaplasma sp. Além de um aumento do $\mathrm{pH}$ vaginal, levando à alcalinidade $(\mathrm{pH}>4,5)$ (BRASIL, 2006; NAUD et al., 2011; WEISSENBACHER et al., 2010). 
Estes lactobacilos são autoinibidos por altos níveis de $\mathrm{H}_{2} \mathrm{O}_{2}$, de modo que os níveis de $\mathrm{H}_{2} \mathrm{O}_{2}$ são auto-regulados na vagina. Em adição ao efeito antimicrobiano do ácido láctico e o consequente $\mathrm{pH}$ ácido, os mecanismos de defesa natural da vagina incluem produção de defensinas endógenas (peptídeos de neutrófilos humanos HNP1-3), inibidor da protease secretada pelos leucócitos (IPSL), citocinas e a mucosa endocervical íntegra (MARRAZZO, 2011).

A VB apresenta secreção vaginal fétida, mais acentuada após a relação sexual e durante o período menstrual, homogênea, branco-acinzentada, de aspecto fluido ou cremoso. Embora o corrimento seja o sintoma mais frequente, quase a metade das mulheres com VB são assintomáticas (BRASIL, 2006).

O corrimento é parte da degradação do gel mucina pelas enzimas das bactérias associadas a VB (OLMSTED et al., 2003). O odor, geralmente descrito como de "peixe", é derivado de volatilização das aminas do metabolismo das bactérias anaeróbicas que caracterizam esta desordem. Ocorre o aumento da sialidase (que degrada $\lg A$ ), glicosidase, aminas voláteis, e o perfil de citocinas é característico, e inclui níveis elevados de IL-1 $1 \beta$ e IL-10, e níveis reduzidos de IL-8 (SOBEL, 1997).

O que mais preocupa é que a VB está associada a distúrbios graves, como a doença inflamatória pélvica (LARSSON et al., 2005; SOBEL, 2000) e os resultados adversos da gravidez, como parto prematuro, baixo peso ao nascimento e endometrite pós-parto. VB também aumenta o risco de transmissão do HIV. Também pode levar a infecções neonatais, lesões supurativas, infecções do trato urinário feminino, infecções do trato urogenital masculino e bacteremia mesmo graves têm sido atribuídas a esta espécie (INGIANNI et al, 1997).

Além disso, é a causa mais comum de sintomas vaginais levando as mulheres a procurar cuidados de saúde primários, afetando $8 \%$ a $23 \%$ das mesmas em idade reprodutiva (NAUD et al., 2011; SOBEL, 1997). Estimativas do National Health and Nutrition Examination Survey (NHANES) indicam que 29\% das mulheres americanas com idades entre 14 e 49 anos tem VB. Essas taxas são ainda maiores entre as mulheres com fatores de risco comportamentais e sociodemográficos (KOUMANS et al., 2007).

Embora a etiologia da VB e sua transmissão sexual ainda não sejam claras, estudos epidemiológicos mostram associação entre VB e atividade sexual (FETHERS et al., 2008). Indivíduos da cor negra, múltiplos parceiros sexuais, 
duchas higiênicas, uso irregular do preservativo, uso de álcool e tabaco também foram fatores associados com a presença da VB (MASCARENHAS et al., 2012).

\subsection{Mollicutes}

\subsubsection{Características gerais dos Mollicutes}

O termo genérico molicutes abrange todos os microrganismos pertencentes à Classe Mollicutes $($ Mollis = mole; cútis $=$ pele), ficando a denominação micoplasma relativa aos microrganismos do gênero Mycoplasma. Atualmente, a Classe dos Mollicutes é composta por cinco ordens (Mycoplasmatales, Entomoplasmatales, Acholeplasmatales, Anaeroplasmatales e Incertae sedis), seis famílias (Mycoplasmataceae, Entomoplasmataceae, Spiroplasmataceae, Acholeplasmataceae, Anaeroplasmataceae e Erysipelothrichaceae) e 14 gêneros (Mycoplasma, Eperythozoon, Haemobartonella, Ureaplasma, Entomoplasma, Mesoplasma, Spiroplasma, Acholeplasma, Anaeroplasma, Asteroplasma, Erysipelothrix, Bulleidia, Holdemania e Solobacterium) (BERGEY'S Manual of Determinative Bacteriology, 2001).

O primeiro isolamento de micoplasma foi descrito inicialmente por Edmond Norcard e Emile Roux em 1898, que estudavam a Pleuropneumonia Bovina. O agente etiológico era filtrável, como os vírus, no entanto, também crescia em meio de cultura como as bactérias. Em seguida, microrganismos semelhantes, isolados de humanos e de animais, foram descritos por outros pesquisadores e denominados de PPLO - "Pleuropneumonia-Like Organisms" (MOROWITZ, 2002; RAZIN; JACOBS, 1992).

Os membros da Classe Mollicutes pertencem ao Filo Firmicutes e são caracterizados pelo genoma de tamanho reduzido, ausência de parede celular (RAZIN, 1995) e apresentam requerimentos nutricionais diferenciados quando comparados à maioria das bactérias de interesse humano. Aminoácidos, nucleotídeos e esteróis exógenos são utilizados para seu crescimento "in vitro" (PILO et al., 2005; RUHNKE; ROSENDAL, 1994). A membrana dos micoplasmas tem composição semelhante às das eubactérias e está exposta ao ambiente, com exceção de poucas espécies que possuem glicocálice (WIESLANDER et al., 1992). 
Apresentam o menor genoma conhecido entre os procariotos. Estas bactérias podem ser divididas em dois grupos, de acordo com o tamanho do genoma: um composto pelos gêneros Mycoplasma e Ureaplasma, que possui cerca de 580 a $1350 \mathrm{Kpb}$, e o outro formado pelos gêneros Acholeaplasma, Spiroplasma e Anaeroplasma com 790 a 2200 Kpb (FRASER et al., 1995; MILES; NICHOLAS, 1998).

A simplicidade genômica está correlacionada aos dados filogenéticos que indicam que estão relacionados às bactérias gram-positivas com baixa porcentagem de guanina $(G)$ e citosina $(C)$, e por terem passado por um processo de evolução degenerativa, envolvendo reduções de informações genéticas que estavam presentes em suas antecessoras (GASPARICH et al., 2004; MANILOFF, 2002). Os molicutes perderam a parede celular, algumas vias metabólicas e provavelmente parte da maquinaria genética molecular, simplificando especialmente a replicação do DNA e seus sistemas de reparos (LABARÈRE, 1992).

Quanto ao metabolismo, são divididos em fermentadores, produzindo ácidos por meio da metabolização de glicose e de outros carboidratos, diminuindo o pH do meio de cultivo, e em não- fermentadores que possuem a via da arginina-deidrolase para obtenção de ATP, aumentando o pH (OLSON et al., 1993; RAZIN, 1978). As espécies do gênero Ureaplasma requerem uréia (único entre os organismos vivos) para produzir ATP, hidrolizando este composto e produzindo amônia (BASEMAN; TULLY, 1997; RAZIN, 2004).

O maior impedimento na pesquisa e no diagnóstico laboratorial das infecções causadas por molicutes tem sido a dificuldade em cultivá-los "in vitro". Apresentam crescimento lento, mesmo em meio de cultivo adequado (RAZIN, 1994). Esses microrganismos são altamente pleomórficos, apresentam-se helicoidais, esféricos ou periformes (CARSON; HU; COLLIER, 1992), além de colônias de 50 - 500 um de diâmetro, usualmente em forma de "ovo frito" quando cultivado em meio sólido, visualizadas com o auxílio de microscópio eletrônico (Figura 1). Em meio líquido, o crescimento não causa turvação, provocando somente alteração no pH, revelado por um indicador presente no meio de cultura (RAZIN, 1995). 
Figura 1 - Colônia de $M$. hominis em meio SP4 com sua característica forma de "ovo frito" (aumento 40X).

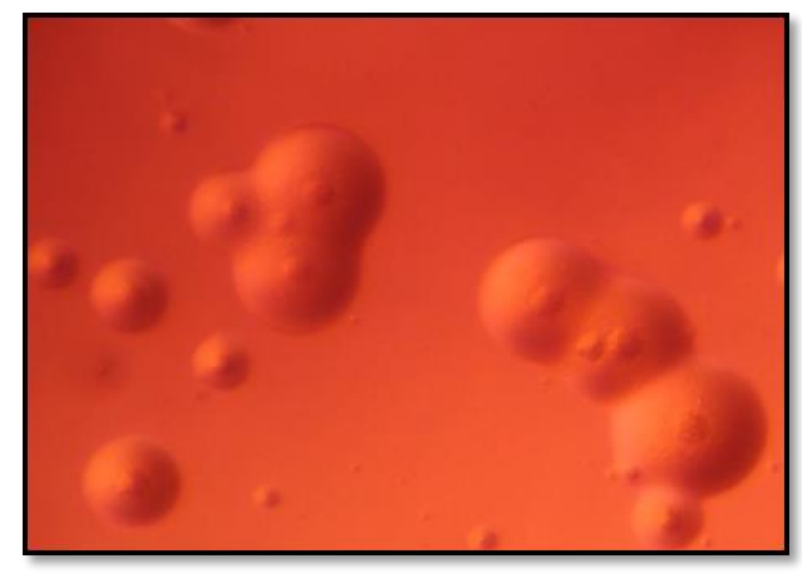

Os molicutes exibem estrita relação aos hospedeiros e especificidade a tecidos e órgãos, que reflete as suas características nutricionais e adaptação parasitária. Estas bactérias podem ocorrer em hospedeiros e tecidos diferentes de seu "habitat" normal. Localizam-se principalmente nas células de mucosas do trato respiratório e urogenital, olhos, glândulas mamárias e articulações em humanos e animais (DYBVIG; VOELKER, 1996; RAZIN, 1992). As mutações têm sido mencionadas como estratégia de sobrevivência, que podem ter ocorrido em função da evolução associada a perdas genômicas (DAVID; BROWNING; WISE, 2002).

Muitas espécies de molicutes expressam variavelmente na superfície celular antígenos estruturalmente heterogêneos. Modificações nos genes que codificam moléculas de adesão capazes de gerar mudanças antigênicas das estruturas de superfície, indicando um importante mecanismo de patogenicidade por mimetizar e evadir-se da resposta imune. Estas variações podem alterar os mecanismos de colonização e penetração dos micoplasmas nos tecidos (LIU et al., 2001; NICOLSON et al., 1999; RAZIN et al., 1998; ROSENGARTEN, YOGEV, 1996; ZIMMERMAN et al., 2011).

Os molicutes que infectam humanos e animais são considerados como parasitas de superfície, pois aderem a mucosa do trato respiratório e urogenital (RAZIN et al., 1998). A maioria das infecções por micoplasmas são limitadas as superfícies mucosas, no qual há estreita associação e aderência com o epitélio hospedeiro (BASEMAN; TULLY, 1997; RAZIN e JACOBS, 1992; WAITES et al., 2009). 
Além de aderir, alguns micoplasmas podem invadir células não fagocíticas. Esta habilidade tem sido estudada em diversos micoplasmas, como M. penetrans, M. fermentans, M. pneumoniae, M. genitalium e M. gallisepticum (ROTTEM, 2002; TAYLOR-ROBINSON; JENSEN, 2011) e mais recentemente no $U$. diversum (MARQUES et al., 2010). A invasão dos micoplasmas no interior das células pode ser considerada uma estratégia de sobreviência, protegendo-o da resposta imune celular do hospedeiro e dificultando a ação dos antibióticos, contribuindo para manutenção da infecção (ANDREEV et al., 1995; MCGOWIN et al., 2009).

Os micoplasmas apresentam interação com o hospedeiro, principalmente com o sistema imune inato e adquirido (GLASS et al., 2000). A ausência da parede celular dos molicutes permite o contato íntimo com as células hospedeiras. $\mathrm{Na}$ microscopia eletrônica e sob condições apropriadas observou-se a fusão destas bactérias com células hospedeiras (ROTTEM, 2002; CUNHA et al., 1997; CHERNOV et al., 1995).

As altas concentrações de metabólitos durante a aderência dos micoplasmas nas células hospedeiras propiciam o processo de dano tecidual (YOU et al., 2006). Produtos de secreção, como a amônia gerada a partir do metabolismo da arginina por M. hominis e a uréia por Ureaplasma spp. pode produzir um efeito citotóxico local (WAITES; KATZ; SCHELONKA, 2005a).

Infecções causadas por micoplasmas geralmente seguem para a cronicidade. A patogenicidade dos micoplasmas ainda não esta bem esclarecida, mas acreditase que os danos relacionados as infecções em humanas ou animais sejam mais prováveis pela respostas imune e inflamatórias do hospedeiro, do que diretamente pelo efeito citotóxico destes microrganismos. No entanto, potentes toxinas estão associadas aos micoplasmas e aos produtos do seu metabolismo, como peróxido de hidrogênio e radicais superóxidos, que têm sido apontados pelos seus efeitos oxidativos às membranas das células hospedeiras (RAZIN, 2004). 


\subsubsection{Ureaplasmas}

Os ureaplasmas são microrganismos pleomórficos, sua morfologia dependente da cepa, do tempo da cultura e do método de observação. Estruturas relacionadas a motilidade não foram observadas. São bactérias, microaerófilas e possuem temperatura ótima de crescimento de $37^{\circ} \mathrm{C}$, mas podem crescer entre 22 e $42{ }^{\circ} \mathrm{C}$. Em meio sólido produzem colônias de 15 a $60 \mu \mathrm{m}$, em pH ideal de 6,0. Ureaplasmas hidrolizam uréia com a produção de amônia. São frequentemente encontrados no trato respiratório e urogenital de humanos e espécies animais (BERGEY'S, 2001).

Ureaplasma urealyticum apresentava-se dividido em dois biovares com 14 sorovares, e considerado até 2002 como a única espécie deste gênero capaz de infectar os seres humanos. Recentemente, foram reclassificados como duas espécies distintas, $U$. parvum (biovar 1) e $U$. urealyticum (biovar 2), com base no tamanho do genoma, nas sequências dos genes 16S rRNA, da região intergênica do 16S-23S rRNA, polimorfismos enzimáticos, hibridação DNA-DNA, crescimento diferencial em resposta ao manganês, subunidades do gene urease e região terminal 5' do antígeno múltiplas-bandas (MBA) (BLANCHARD, 1990; KONG et al., 1999; TENG et al., 1995). Os sorovares foram distribuídos em: U. parvum com os sorovares 1, 3, 6 e 14, e U. urealyticum com os sorovares, 2, 4, 5, 7, 8, 9, 10, 11, 12 e 13 (ROBERTSON et al., 2002; XIAO et al., 2010).

Essas espécies de ureaplasma colonizam o trato urogenital de pessoas saudáveis, no entanto, eles foram incluídos entre os agentes infecciosos causadores de doenças urogenitais em humanos (KRAUSE, 1992). Mesmo assim, a infecção e a distribuição destes microrganismos em diversos grupos populacionais ainda são pouco conhecidas (CORDOVA E CUNHA, 2002), e variam em relação com vários parâmetros como idade, cor, estado hormonal, bem como o número de parceiros sexuais da vida (POVLSEN; THORSEN; LIND, 2001).

O U. parvum é o mais comumente isolado de amostras clínicas, especialmente em mulheres grávidas. $U$. urealyticum foi isolado com maior frequência de mulheres que tiveram parto prematuro com o diagnóstico clínico de VB, mulheres com aborto espontâneo e mulheres com DIP. Algumas amostras genitais podem conter estirpes pertencentes a ambos os biovares (WAITES; TALKINGTON, 2005b). O diagnóstico clínico da infecção genital por ureaplasma é 
complicado de ser estabelecido, uma vez que não existe sintoma característico e, geralmente esses microrganismos estão envolvidos com patologias multicausais (SIMOES, 1999).

As duas espécies de ureaplasma estão associadas a quadros de uretrite nãogonocócica e não-clamidial (ONDONDO et al., 2010), doença inflamatória pélvica (DIP), endometrite, infertilidade e a condições que podem afetar a gestação, o desenvolvimento do feto e do recém-nascido. Contribuem para o trabalho de parto prematuro, corioamnionite espontânea, aborto espontâneo, prematuridade e baixo peso ao nascer. O recém-nascido exposto pode desenvolver pneumonia, meningite, bacteremia, abscessos e displasia broncopulmonar (SUNG, 2010; XIAO et al., 2010).

Ureaplasmas podem ser isolados da superfície mucosa da vagina ou cérvice de 40 a $80 \%$ de mulheres saudáveis sexualmente ativas. A infecção é transmitida por contato sexual, ou pode ocorrer de forma vertical por passagem transplacentária, e ainda no momento do parto (WAITES; KATZ; SCHELONKA, 2005a). Ureaplasma spp. pode ser isolado de recém-nascidos de mães com membranas aminióticas íntegras e parto cesário, indicando transmissão transplacentária (WAITES; TALKINGTON, 2005b). A ocorrência no trato urogenital de homens saudáveis é de cerca de 20 a 29\% (KONG et al., 2000; XIAO et al., 2010).

A amônia, liberada na hidrólise da uréia, pela urease dos ureaplasmas, pode ser considerada um fator de virulência, que provavelmente interfere nos tecidos adjacentes aos ureaplasmas. Outro fator de virulência é a atividade de fosfolipase A1, A2 e C. Quando a infecção atinge a placenta, as fosfolipases dispara a produção de ácido araquidônico livre. Isto pode ativar a síntese de prostaglandinas e, possivelmente, induzir o parto prematuro (DE SILVA; QUINN, 1991; WAITES et al., 2009).

O possível papel dos ureaplasmas genitais em doenças do trato reprodutivo feminino, na gravidez ou causando infertilidade tem sido debatido desde 1970 e ainda não há respostas claras para muitas perguntas que continuam a ser levantadas. A associação inicial com a infertilidade ocorreu após o cultivo destas bactérias do trato genital inferior, mais comumente em casais inférteis. Estes achados não foram encontrados de forma consistente em investigações subsequentes. Culturas de tecido endometrial obtidos por laparoscopia também têm 
demonstrado que os ureaplasmas podem ser isolados, com maior frequência, de mulheres inférteis (WAITES; TALKINGTON, 2005b).

\subsection{Outros microrganismos de importância ginecológica}

\subsubsection{Chlamydia trachomatis}

Desde a década de 80, a infecção pela $C$. trachomatis é considerada como uma das IST mais frequentes em todo mundo. A OMS estima que em 2008 ocorreram em torno de 105 milhões de novos casos de clamídia, afetando principalmente adolescentes e adultos jovens (KUCINSKIENE et al., 2006; WHO, 2001, 2012). A infecção por clamídia é uma preocupação de saúde pública devido aos efeitos desfavoráveis que podem ocorrer com relação à reprodução humana (WHO, 2001). Em mulheres, este microrganismo causa DIP e as consequências devido aos longos períodos de infecção e pela fibrose, e consequentemente, cicatrizes devido à reparação do tecido danificado pela inflamação (OHMAN et al., 2011), ocasionando cervicite, infertilidade, gravidez ectópica e dor pélvica (BARRETT; TAYLOR, 2005; BRUNHAM e REY-LADINO, 2005; HAGGERTY; NESS, 2006).

A infecção é assintomática em aproximadamente $70 \%$ dos casos (SALFA et al., 2011). Portanto, o diagnóstico e tratamento nas pessoas infectadas são essenciais para a prevenção da DIP, infertilidade e gravidez ectópica (PAAVONEN e LEHTINEN, 1996; PETROVAY et al., 2009). Sabe-se que entre $10 \%$ a $40 \%$ das mulheres com cervicites por clamídia, não tratadas clinicamente, desenvolvem sintomas de DIP (PLATT; RICE; MCCORMACK, 1983; STAMM et al., 1984; TOTH et al., 2000). A gravidade dessas sequelas está relacionada com a duração da doença (SATO et al., 2005; WHO, 2005). No Brasil, alguns estudos têm mostrado uma prevalência de infecções por $C$. trachomatis, variando de cinco a $19,6 \%$ entre os jovens que frequentam ambulatórios e clínicas ginecológicas, e participam em Programa Saúde da Família (ARAÚJO et al., 2006; GUIMARÃES et al., 2009).

Os membros da família Chlamydiaceae são parasitas intracelulares obrigatórios. São bacilos gram-negativos pequenos, desprovidos da camada de peptidioglicano na parede celular e parasitas intracelulares estritos de seres humanos (MIRANDA; GADELHA; PASSOS, 2003). A bactéria possui um ciclo de 
desenvolvimento bifásico e replicação dentro de vacúolos (fagossomos) na célula hospedeira, formando inclusões citoplasmáticas características (BRUNHAM; REYLADINO, 2005). Isso garante um meio ambiente livre da competição com outros microrganismos e preservação da ação do sistema imune (SILVA FILHO; LONGATTO, 2000).

No local da infecção na mucosa, pode ocorrer uma intensa inflamação que é caracterizada pela vermelhidão e edema, resultando numa cervicite mucopurulenta em mulheres e uretrites não gonocócicas em homens (BERLE et al., 2012; PEIPERT, 2003). As manifestações clínicas da infecção por clamídias são devidas a destruição celular durante a multiplicação e resposta inflamatória do hospedeiro (MURRAY et al., 2004). Entretanto, apesar da localização inicial da inflamação, a infecção por $C$. trachomatis permanece na forma subclínica em alta proporção em pessoas infectadas $(70 \%$ - 90\% em mulheres e $30 \%-50 \%$ em homens) (PEIPERT, 2003).

\subsubsection{Gardnerella vaginalis}

Na década de 1950, Leopold (1953) e, em seguida, Gardner e Dukes (1954) observaram microrganismos pleomórficos gram-variáveis no trato genital de mulheres com VB. Este organismo, chamado pela primeira vez de Haemophilus vaginalis (GARDNER; DUKES, 1955), agora é classificado como Gardnerella vaginalis, o único membro do gênero Gardnerella (GELBER et al., 2008).

Gardnerella vaginalis, um cocobacilo gram-positivo, constituinte da microbiota vaginal, cresce em altas concentrações em quadros de vaginose bacteriana (GREENBLATT et al., 1999), embora possa ser detectada em mulheres saudáveis (HILLIER, 1998). A VB é o distúrbio vaginal mais prevalente em mulheres em idade reprodutiva, afetando $10-20 \%$ das mulheres brancas, e $30-50 \%$ das mulheres afroamericanas, embora as estimativas de sua prevalência dependam da população estudada (PATTERSON et al., 2010).

G. vaginalis está presente em até $95 \%$ dos casos de VB (CATLIN, 1992; MARRAZZO et al., 2008.). No entanto, com o avanço das ferramentas moleculares, demonstrou-se que os números de anaeróbios e diversidade associados a BV são altos. Um estudo revelou que as culturas puras de $G$. vaginalis nem sempre provoca 
VB, e que esse organismo pode ocorrer, embora em número reduzido, em mulheres saudáveis (FREDRICKS et al., 2007; GARDNER; DUKES, 1955).

A adesão é um primeiro passo importante na infecção, a fim de evadir os mecanismos de defesa do hospedeiro. Swidsinski et al. (2005) mostraram que G. vaginalis é capaz de formar um biofilme aderente sobre o epitélio vaginal de mulheres com VB. O biofilme incorpora outros grupos bacterianos nas suas camadas, sugerindo que pode permitir que outros anaeróbios colonizem a vagina.

A formação do biofilme é um fator de virulência importante porque confere tolerância e resistência a antibióticos (SHA et al., 2005). Devido ao fato de que as bactérias de biofilme não são eficazmente eliminadas pelo sistema imune do hospedeiro, ou por antibióticos, as infecções relacionadas com biofilme tendem a ser crônicas e / ou recorrentes. De fato, a evidência direta da análise microscópica de biópsias vaginais de mulheres com VB, revelou a presença de um biofilme bacteriano sobre o epitélio vaginal (SWIDSINSKI et al., 2005, 2008).

G. vaginalis também produz a toxina vaginolisina, que é um membro da família de toxinas colesterol-dependente formadoras de poros, que lisa os glóbulos vermelhos humanos e células epiteliais vaginais (GELBER et al., 2008; NUGENT et al., 1991; OBATA-YASUOKA et al., 2002; ROTTINI et al., 1990).

Embora diversos microrganismos anaeróbios associados a VB foram testados, em um estudo realizado por Patterson et al. (2010), apenas G. vaginalis exibiu alta citotoxicidade, forte aderência as células epiteliais da vagina, e uma propensão para formar um biofilme denso, sendo que estes resultados sugerem um papel fundamental da $G$. vaginalis na patogenia da VB. Fatores de virulência adicionais produzidos por $G$. vaginalis incluem sialidase e prolidase, que são duas enzimas hidrolíticas que podem ter um papel-chave na degradação de diversos fatores de proteção de mucosas, tais como mucinas, bem como contribuem para a esfoliação e descolamento de células epiteliais vaginais. 


\subsubsection{Neisseria gonorrhoeae}

Neisseria gonorrhoeae, um diplococo Gram-negativo, é agente patogênico humano- específico transmitido através do contato sexual com um indivíduo infectado. A gonorréia apresenta-se como uma uretrite aguda em homens e cervicite em mulheres (WIESNER; THOMPSON, 1980). O gonococo é altamente adaptado ao humano e, portanto, desenvolveu mecanismos de patogênese que estão, em parte, dependente do local da infecção (EDWARDS; APICELLA, 2004).

A abordagem padrão para a triagem de gonorréia é muitas vezes restrito a triagem urogenital em muitos países. No entanto, a gonorréia pode ser transmitida através do sexo urogenital, anorretal ou oral desprotegido (KOEDIJK et al., 2012). A OMS estima que em 2008 foram 106 milhões de casos novos de gonorréia em todo o mundo, em adultos jovens (WHO, 2012). Gonorréia é a segunda infecção bacteriana sexualmente transmissível mais comum no Reino Unido e tem uma epidemiologia complexa (MARTIN et al., 2004). Em 2010, um total de 32.028 casos de gonorréia foram relatados por 28 países europeus. Dada as graves implicações da infecção gonocócica, que incluem a DIP, infertilidade, gravidez ectópica, aborto e um aumento de cinco vezes no risco de transmissão do HIV, a necessidade de um tratamento eficaz e controle de gonorreia é evidente (WHO, 2011).

Infecções não tratadas com N. gonorrhoeae em homens e mulheres, podem resultar na cervicite, uretrite e DIP. Pode ainda levar a infecções disseminadas, gravidez ectópica, infertilidade ou aborto (BARRETT; TAYLOR, 2005; HAGGERTY; NESS, 2006). Uma infecção por gonorréia aumenta em cinco vezes o risco de transmissão do HIV (COHEN, 1998; CHISHOLM et al., 2013; KENT et al., 2003).

Devido à natureza frequentemente assintomática da infecção feminina, a gonorréia é uma das principais causas de doença inflamatória pélvica, caracterizada por dor abdominal e cicatriz tubária que resulta em gravidez ectópica e infertilidade. Casos não tratados em homens também levam à esterilidade. Infecções disseminadas podem causar a síndrome artrite-dermatite, endocardite e meningite. N. gonorrhoeae também pode ser transmitida verticalmente durante o parto e ainda é uma das principais causas de cegueira neonatal infecciosas no mundo em desenvolvimento (WIESNER; THOMPSON, 1980).

$N$. gonorrhoeae promove uma resposta inflamatória que é caracterizada pelo recrutamento de neutrófilos. Nos homens, os neutrófilos aparecem em esfregaços 
uretrais e na urina vários dias após a infecção e, imediatamente antes do aparecimento dos sintomas (COHEN; CANNON, 1999). As secreções cervicais de mulheres com gonorréia também contém neutrófilos (BORREGAARD, 2010; EVANS, 1977). No entanto, apesar dos numerosos neutrófilos no local da infecção gonocócica, $N$. gonorrhoeae viáveis podem ser cultivados a partir das exsudações de indivíduos infectados (WIESNER; THOMPSON, 1980).

Apesar dos muitos avanços na compreensão da patogênese gonocócica, os fatores que regem a apresentação divergente da doença gonocócica observada entre homens e mulheres permanecem obscuros. Isto é, enquanto que a infecção na uretral masculina normalmente resulta em uma resposta inflamatória aguda, a gonorréia cervical é predominantemente assintomática. Este estado assintomático tem um impacto na prevalência de gonorréia na população em geral e na sequelas de doenças crônicas observadas entre as mulheres (EDWARDS, 2010).

\subsubsection{Trichomonas vaginalis}

Trichomonas vaginalis, protozoário flagelado, agente etiológico da tricomoníase, doença sexualmente transmissível não viral mais prevalente no mundo. A OMS estimou cerca de 276 milhões de casos novos de tricomoníase no mundo em 2008, em pessoas entre 15 e 49 anos (FICHOROVA, 2009; GERBASE et al., 1998; WHO, 2012). É uma doença de idade reprodutiva e raramente as manifestações clínicas da infecção são observadas antes da menarca ou após a menopausa (PETRIN et al., 1998).

T. vaginalis tem se destacado como um dos principais patógenos do homem e da mulher e está associado a sérias consequências como, complicações na gravidez, infertilidade, parto prematuro e baixo peso do recém-nascido (KLEBANOFF et al., 2001). Nos homens é geralmente assintomática, e muitas vezes é autolimitada. No entanto, pode variar para um estado sintomático, caracterizado por uretrite purulenta, disúria e ardência imediatamente após relação sexual (PETRIN et al., 1998).

As manifestações patológicas variam desde a apresentação assintomática até um estado de severa inflamação (vaginite). Mulheres com vaginite aguda têm corrimento abundante, bolhoso, de coloração amarelada ou amarelo-esverdeada; prurido e/ou irritação vulvar; dor pélvica; sintomas urinários (disúria, polaciúria); e 
hiperemia da mucosa, com placas avermelhadas (BRASIL, 2006). Das mulheres assintomáticas, $50 \%$ deverão tornar-se sintomáticas durante os seis meses seguintes (KRIEGER, 1995).

A infecção por $T$. vaginalis aumenta $\circ \mathrm{pH}$ da vagina, já que $\mathrm{pH}$ normal é ácido $(3,8$ a 4,5) e o organismo cresce em $\mathrm{pH}$ maior que 5 . A elevação do $\mathrm{pH}$ é concomitante com a redução dos lactobacilos da microbiota vaginal, e de um aumento das bactérias anaeróbicas (MACIEL et al., 2004).

Nos últimos anos, o diagnóstico da $T$. vaginalis no trato geniturinário em clínicas médicas manteve-se relativamente constante entre homens e mulheres. No ano de 2004, foram diagnosticados 6.235 casos de tricomoníase na Inglaterra, da qual 5.938 foram em mulheres e 297 em homens (BELL et al., 2007). A Pesquisa Nacional de Exame de Saúde e Nutrição de 2001-2004 constatou que 3,1\% das mulheres americanas eram positivas para infecções genitais por $T$. vaginalis. Brotman et al. (2012) estimaram uma incidência de 5 milhões de novos casos de tricomoníase anualmente nos Estados Unidos. E no Reino Unido houve 6.029 casos de infecção por T. vaginalis em 2007. Aproximadamente metade das mulheres infectadas era assintomática (MITCHELL; HUSSEY, 2010).

\subsection{Citocinas}

O sistema imune inato reconhece padrões moleculares associados aos patógenos (PAMPS) nos microrganismos invasores, ao invés de reconhecer antígenos específicos. Os fatores da imunidade inata que atuam na vagina são representados por fatores solúveis (tais como lecitina ligadora de manose - MBL, componentes do sistema complemento, defensinas, inibidor da protease secretória dos leucócitos - SLPI e óxido nítrico), componentes associados a membranas ("Tolllike receptors" - TLR) e células fagocitárias. O reconhecimento de um PAMP por um componente da imunidade inata desencadeia uma sequência de eventos que leva à liberação de citocinas pró-inflamatórias e, consequentemente, à ativação do sistema imune adquirido, ou seja, ativação de linfócitos T e B (LINHARES; GIRALDO; BARACAT, 2010).

No trato genital feminino, as defesas imunes inatas incluem o próprio epitélio de barreira, a presença de muco, o pH ácido mediado pela microbiota composta predominantemente de Lactobacillus $\mathrm{sp}$ e mediadores solúveis como proteínas do 
complemento e peptídeos antimicrobianos (LIMA; ALVES, 2008; WITKIN et al., 2000).

A resposta imunológica mais comum durante infecção por ureaplasmas

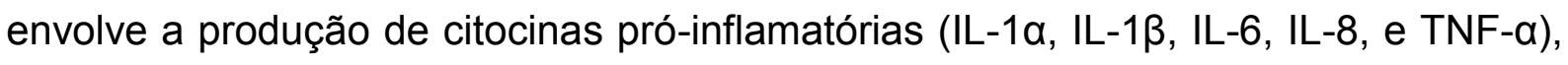
acompanhada por infiltração de neutrófilos e macrófagos nos locais de infecção. Entretanto, as complexas interações entre ureaplasma e o hospedeiro que levam a simples colonização ou ao desenvolvimento de doenças são em grande parte desconhecidos (REYES et al., 2006).

As citocinas são proteínas de baixo peso molecular secretadas por leucócitos e outras inúmeras células do organismo em resposta a diferentes estímulos, atuando como mediadoras das células do sistema imune (ULICH et al., 1991). São responsáveis pela diferenciação dos vários tipos celulares, por exemplo as células $T$, levando a uma complexa rede de atividades imunológicas que atrai células para o sítio da lesão, e fazem o processo de defesa do hospedeiro (MACHADO et al., 2004; ROCK et al., 2010).

Neste contexto, alguns estudos relacionam os polimorfismos de citocinas com a presença de microrganismos e as vaginoses bacterianas. Jeremias et al. (1999) associaram o polimorfismo do receptor da citocina IL-1 com a presença de $U$. urealyticum e $M$. hominis. As citocinas $\mathrm{IL}-1 \alpha$ e $\mathrm{IL}-1 \beta$ estão envolvidas na proliferação, diferenciação e apoptose celular. IL-1ß e uma proteína extracelular secretada pelas células (DINARELLO, 1996).

A IL-1 $1 \beta$ está presente em grandes quantidades no meio intracelular de células epiteliais, e é liberada quando ocorre um dano ao epitélio celular. Age como agonista de Toll-like receptor (TLR) expressos por células da imunidade inata e induzem a ativação do fator nuclear KB (NF-kB), que induz a expressão de citocinas próinflamatórias, quimiocinas e defensinas na resposta inflamatória (LIMA; ALVES, 2008).

IL-1 desempenha papel central na regulação da resposta inflamatória em tecidos lesados e na infecção intra-uterina é produzida por células deciduais humanas em resposta a endotoxinas bacterianas (FIORENTINO; BOND; MOSMANN, 1989). Em gestantes com corioamnionite clínica e histológica, a IL-1 $\beta$ é expressa em células inflamatórias, sendo os macrófagos a principal fonte dessa citocina nesses tecidos (MUELLER-HEUBACH et al., 1990). A IL-1 $\beta$ está implicada no início do trabalho de parto prematuro associado a infecção. Além disso, pode 
induzir a produção de prostaglandina pelo epitélio amniótico e estimular a contratilidade miometrial (FORTUNATO; MENON, 2001).

A IL-6 é uma citocina multifuncional expressa em diferentes tipos de células, contribuindo na diferenciação das células $B$ e na proliferação de células $T$. Esta proteína e considerada a principal mediadora da resposta do hospedeiro a infecção. A IL-6 esta envolvida na patogênese de diversas doenças, tais como artrite reumatóide, psoríase, doença de Alzheimer e também a doença periodontal (MOREIRA et al., 2007; TERVONEN et al., 2007; TREVILATTO et al., 2003).

A citocina IL-6 é produzida na fase inicial da infecção, e responsável pelo aumento da expressão das moléculas de adesão (selectina $\mathrm{P}$ e pelas moléculas de adesão intercelular - ICAM), facilitando a passagem de células do vaso para o sítio da infecção, e também estimulam os neutrófilos e macrófagos a produzirem óxido nítrico (NO) e a destruírem as bactérias (MACHADO et al., 2004). Altos níveis de IL6 foram associados com a presença de inflamação cervical, com microbiota vaginal alterada, e com a gravidez (STURM-RAMIREZ et al., 2000).

Taylor et al. (2013) mostraram associação positiva entre os níveis de IL-6 no fluido cérvico-vaginal e trabalho de parto prematuro. Associação de IL-6 com parto prematuro acompanhada por corioamnionite pode sugerir um aumento na resposta inflamatória após a infecção microbiana do trato vaginal. Alguns estudos também associam aumento dos níveis de IL-6 no plasma com infecção gonocócica em mulheres, e esse aumento foi potencializado por co-infecções com outros patógenos sexualmente transmissíveis (HEDGES et al., 1998). 


\section{OBJETIVOS}

\subsection{Objetivo geral}

- Detectar Ureaplasma urealyticum e U. parvum no trato genital feminino e relacionar com polimorfismo genético e expressão de citocinas em mulheres com ou sem distúrbios genitais atendidas no município de Vitória da Conquista - BA.

\subsection{Objetivos específicos}

- Detectar Ureaplasma urealyticum e U. parvum por meio da PCR convencional em mulheres, com ou sem distúrbios genitais, atendidas no município de Vitória da Conquista - BA.

- Detectar os Sorotipos do U. parvum por meio da PCR convencional em mulheres, com ou sem distúrbios genitais, atendidas no município de Vitória da Conquista - BA.

- Quantificar Ureaplasma urealyticum e U. parvum por meio da PCR em tempo real em mulheres, com ou sem distúrbios genitais, atendidas no município de Vitória da Conquista - BA.

- Realizar diagnóstico diferencial de outros microrganismos (Trichomonas vaginalis, Gardnerella vaginalis, Chlamydia trachomatis e Neisseria gonorrhoeae) de importância ginecológica em mulheres, com ou sem distúrbios genitais, atendidas no município de Vitória da Conquista - BA.

- Realizar a análise molecular por MS-PCR dos polimorfismos da citocina IL-6 em mulheres, com ou sem distúrbios genitais, atendidas no município de Vitória da Conquista - BA.

- Realizar a análise molecular por PCR-RFLP dos polimorfismos da citocina IL$1 \beta$ em mulheres, com ou sem distúrbios genitais, atendidas no município de Vitória da Conquista - BA.

- Confirmar os polimorfismos genéticos das citocinas IL-6 e IL-1 $1 \beta$ por meio do sequenciamento. 
- Dosar as citocinas por ELISA no soro de mulheres, com ou sem distúrbios genitais, atendidas no município de Vitória da Conquista - BA.

- Relacionar os dados de detecção e quantificação dos microrganismos e os polimorfismos genéticos das citocinas obtidos. 


\section{MATERIAIS E MÉTODOS}

\subsection{População do estudo}

O estudo foi aprovado pelo Comitê de Ética em Pesquisa Envolvendo Seres Humanos (CEPSH) do Instituto de Ciências Biomédicas da Universidade de São Paulo (ICB/USP) conforme o Protocolo $n^{\circ} 1015$, e pela Secretaria de Saúde de Vitória da Conquista.

Todas as instruções contidas no Termo de Consentimento Livre e Esclarecido (TCLE) foram explicadas à paciente, que eram então convidadas a participar da pesquisa e a assinar o termo. Em caso de resposta negativa procedeu-se com o atendimento previsto para coleta de material citopatológico (Papanicolaou) para a Unidade de Saúde. Foram excluídas mulheres grávidas, HIV positivo, que não iniciaram a atividade sexual, e que fizeram uso de antibióticos nos três meses anteriores a coleta.

Foram analisadas amostras clínicas e respostas do questionário (Apêndice A) de 302 mulheres com idade entre 14 e 78 anos atendidas por demanda espontânea em cinco Unidades de Saúde da Família (USF) do município de Vitória da Conquista - BA. No questionário foram avaliados dados demográficos e o histórico sexual e reprodutivo.

\subsection{Descrição da Região do estudo}

Vitória da Conquista, município da região sudoeste da Bahia, a $503 \mathrm{~km}$ de distância da capital (Salvador), com área territorial de $3.356,886 \mathrm{~km}^{2}$ e população estimada em 315.884 habitantes em 2012. Destes, 48,2\% são do sexo masculino e $51,8 \%$ do sexo feminino. Cerca de $89,5 \%$ da população residem na região urbana da cidade e $10,5 \%$ na região rural. Apresenta clima tropical, amenizado pela relativa altitude do lugar (923 $\mathrm{m}$ ), e é uma das cidades que registram as temperaturas mais amenas no estado da Bahia, com média de $20{ }^{\circ} \mathrm{C}$. A cidade possui a quinta maior economia do estado da Bahia, com participação de $2,29 \%$ no Produto Interno Bruto (PIB) estadual. O desenvolvimento da cidade também é atestado pelos índices econômicos e sociais. O IDE - Índice de Desenvolvimento Econômico subiu do $11^{\circ}$ lugar no ranking baiano, em 1996, para 9, em 2000. O IDS - Índice de 
Desenvolvimento Social deu um salto: subiu do $24^{\circ}$ para o $6^{\circ}$ lugar. O IDH - Índice de Desenvolvimento Humano também saltou do $30^{\circ}$ lugar em 1991 para $18^{\circ} \mathrm{em}$ 2000.

O setor de saúde ganhou novas dimensões e a Rede Municipal de Saúde se tornou, a partir de 1997, referência para todo o País. O Programa Saúde da Família é a base do sistema municipal de saúde. O município conta com 38 equipes, representando uma cobertura de 63\%. Das 38 equipes, 15 estão na zona rural. São 28 Unidades de Saúde da Família (USF), distribuídas entre a zona urbana e rural (IBGE, 2010; MEDEIROS, 1996).

\subsection{Coleta das amostras}

As coletas ocorreram entre os meses de Maio, Junho e Julho de 2011 e Janeiro de 2012. Estas ocorreram nos consultórios, de enfermagem ou médico, de cada uma das cinco Unidades de Saúde da Família (USFs) participantes do estudo (USF do Pradoso, USF da Urbis V, USF CSU, USF Nelson Barros e USF do Miro Cairo) e foram realizadas pelos responsáveis da pesquisa e por vezes, quando solicitado, pelos profissionais de saúde dos postos que eram habilitados para realização de tal procedimento. Nas oportunidades em que profissionais dos postos realizaram a coleta, sempre havia um dos responsáveis pela pesquisa para contribuir na validação do estudo proposto. Neste contexto, foram observadas as condições de assepsia adequadas, e também foi notada a infraestrutura disponível em cada USF.

$\mathrm{Na}$ ocasião da coleta, o operador utilizava Equipamentos de Proteção Individual (EPIs) - máscara, luvas e gorro, para garantir a sua segurança bem como para assegurar a assepsia do procedimento. Para realização da coleta de amostra genital foram utilizados swabs estéreis. Com auxílio do espéculo, os swabs foram friccionados de forma suave na superfície mucosa da vagina e do colo do útero da mulher de modo que absorvesse a maior quantidade de corrimento ou muco cervical possível. O swab foi armazenado em tubo com $5 \mathrm{~mL}$ de meio de transporte como descrito por Bussolo et al. (1981) com algumas modificações. Os tubos foram mantidos em caixa isotérmica refrigerada, até o processamento em laboratório. 
A coleta do material sanguíneo ocorreu por meio de punção venosa periférica, em membro superior. Foram coletados cerca de $5 \mathrm{~mL}$ de sangue em cada um dos tubos, com e sem EDTA.

Por fim, o material foi levado até o Laboratório de Microbiologia e Imunologia da Universidade Federal da Bahia - Campus Anísio Teixeira, localizado na cidade de Vitória da Conquista, para processamento e armazenamento em freezer. Os tubos de ensaio com os swabs foram homogeneizados em aparelho tipo vórtex para eluição do material clínico, distribuídos e identificados em microtubos em volumes de $1,0 \mathrm{~mL}$. O sangue periférico contido em tubos tipo Vacutainer ${ }^{\circledR}$ com EDTA foram acondicionados prontamente a $-20{ }^{\circ} \mathrm{C}$. Os tubos sem EDTA foram centrifugados a 3.500 rpm para obtenção do soro, seguido de sua distribuição em alíquotas de cerca de $1,0 \mathrm{~mL}$ e estocados a $-20^{\circ} \mathrm{C}$ até o uso.

\subsection{Cepas utilizadas}

Cepas de Ureaplasma urealyticum e U. parvum foram obtidas da coleção de microrganismos do Laboratório de Micoplasmas do Instituto de Ciências Biomédicas da Universidade de São Paulo. Destas cepas foram extraídos os respectivos DNAs para o controle dos testes moleculares realizados com as amostras clínicas.

Para o controle dos experimentos de detecção dos demais microrganismos de interesse ginecológico (Trichomonas vaginalis, Gardnerella vaginalis, Chlamydia trachomatis e Neisseria gonorrhoeae), foram utilizadas cepas de amostras clínicas cedidas pelo Professor Dr. Jorge Luiz Mello Sampaio, da Faculdade de Ciências Farmacêuticas da Universidade de São Paulo e Pesquisador Associado do Instituto Fleury.

\subsection{Extração de DNA das amostras de swab vaginal}

A extração de DNA das amostras de material genital ocorreu por meio da técnica descrita por Fan et al., (1995) também conhecida por método de fervura. $O$ procedimento ocorreu a partir de $1,0 \mathrm{~mL}$ do material. Em microtubos, estes volumes foram centrifugados a $10.000 \mathrm{rpm}$ por 10 minutos. Em seguida, foi descartado o sobrenadante e o sedimento lavado com $100 \mu \mathrm{L}$ de PBS $(\mathrm{pH} 7,2)$. A suspensão foi homogeneizada e centrifugada a $10.000 \mathrm{rpm}$ por 10 minutos por duas vezes. $\mathrm{O}$ 
sobrenadante de cada amostra clínica lavada foi removido e o sedimento homogeneizado em $40 \mu \mathrm{L}$ de PBS ( $\mathrm{pH} 7,2)$. Em seguida, cada amostra foi fervida por 10 minutos e resfriada em gelo por 5 minutos. Depois, as amostras foram centrifugadas mais uma vez a 10.000 rpm durante 10 minutos. E por fim, foi coletado o sobrenadante contendo o DNA liberado do citoplasma, devido à lise celular. Realizada a extração, as amostras foram estocadas a $-20^{\circ} \mathrm{C}$ até o momento do uso.

\subsection{Padronização da Reação em Cadeia da Polimerase (PCR) convencional}

\subsubsection{PCR para detecção de Mollicutes}

Para realização da reação em cadeia da polimerase (PCR) foi adicionado a um microtubo (0,2 mL) 1X de Tampão (Buffer), 50 pmol de cada iniciador, $(0,1 \mu \mathrm{L})$, 1,0 U de Taq DNA polimerase (Invitrogen, São Paulo, S.P., Brasil), 2,0 mM de $\mathrm{MgCl}_{2}, 200 \mu \mathrm{M}$ de deoxiribonucleotídeos trifosfato (dNTP), 1,0 $\mu \mathrm{L}$ da amostra de DNA e água ultrapura até o volume final de $50 \mu \mathrm{L}$. A amplificação foi realizada em termociclador programado para: um ciclo de $94{ }^{\circ} \mathrm{C}$ por $5 \mathrm{~min}, 34$ ciclos de $94{ }^{\circ} \mathrm{C}$ por $30 \mathrm{~s}, 57,7{ }^{\circ} \mathrm{C}$ por $30 \mathrm{~s}, 72{ }^{\circ} \mathrm{C}$ por $1 \mathrm{~min}$, um ciclo final de $72{ }^{\circ} \mathrm{C}$ por $10 \mathrm{~min}$ e hold step a $4{ }^{\circ} \mathrm{C}$. O quadro 1 mostra as sequências do par de iniciadores utilizados nos testes para amplificar parte do gene da unidade 16s do rRNA de qualquer espécie da classe Mollicutes. O produto amplificado esperado foi de 270 pb (VAN KUPPEVELD et al., 1992).

Quadro 1 - Sequências dos iniciadores utilizados para amplificação do gene 16S rRNA para Mollicutes e peso molecular do produto amplificado.

\begin{tabular}{|ccc|}
\hline Iniciadores & Sequência & Produto \\
\hline GPO3 & 5' GGGAGCAAACACGATAGATACCCT 3' & \\
MGSO & 5' TGCACCATCTGTCACTCTGTTAACCTC 3' & $270 \mathrm{pb}$ \\
\hline
\end{tabular}




\subsubsection{PCR para detecção de U. urealyticum}

O mix da reação foi preparado a $50 \mu \mathrm{L}$ contendo: 1x PCR Tampão; $200 \mu \mathrm{M}$ de dNTP, 2,5 mM de $\mathrm{MgCl}_{2}$, 20 pmol de cada primer, 2,5 U de Taq DNA Polimerase (Invitrogen, São Paulo, S.P., Brasil) e 3,0 $\mu \mathrm{L}$ de DNA. A amplificação foi realizada em termociclador, obedecendo a uma desnaturação inicial de $95{ }^{\circ} \mathrm{C}$ por $5 \mathrm{~min}$, seguida de 35 ciclos de $45 \mathrm{~s}$ a $94^{\circ} \mathrm{C}, 45 \mathrm{~s}$ a $55^{\circ} \mathrm{C}$ e $45 \mathrm{~s}$ a $72{ }^{\circ} \mathrm{C}$, e uma extensão final a $72{ }^{\circ} \mathrm{C}$ por $10 \mathrm{~min}$. Os produtos das amplificações foram analisados por eletroforese em gel de agarose $1,0 \%$, corados com brometo de etídio $(10 \mathrm{mg} / \mathrm{mL})$ e fotografados em fotoducumentador com transluminador. O quadro 2 mostra as sequências do par de iniciadores utilizados nos testes, para amplificação de 476 pb do amplicon da região do gene $16 \mathrm{~S}$ rRNA do $U$. urealyticum (DE FRANCESCO et al., 2009).

Quadro 2 - Sequências dos iniciadores utilizados para amplificação do gene $16 S$ rRNA para $U$. urealyticum e peso molecular do produto amplificado.

\begin{tabular}{|ccc|}
\hline Iniciadores & Sequência & Produto \\
\hline UMS170 & 5' GTATTTGCAATCTTTATATGTTTTCG 3' $^{\prime}$ & \\
UMA263 & 5' TTTGTTGTTGCGTTTTCTG 3' $^{\prime}$ & $476 \mathrm{pb}$ \\
\hline
\end{tabular}

\subsubsection{PCR para detecção de U. parvum}

O mix da reação foi preparado a $50 \mu \mathrm{L}$ contendo: 1x PCR buffer; $200 \mu \mathrm{M}$ de dNTP, 2,5 mM de $\mathrm{MgCl}_{2}, 20$ pmol de cada primer, 2,5 $U$ de Taq DNA Polimerase (Invitrogen, São Paulo, S.P., Brasil) e 3,0 $\mu \mathrm{L}$ de DNA. As amplificações foram realizadas em termociclador, obedecendo a uma desnaturação inicial de $95^{\circ} \mathrm{C}$ por 5 min, seguida de 35 ciclos de 45 s a $94{ }^{\circ} \mathrm{C}, 45$ s a $55^{\circ} \mathrm{C}$ e 45 s a $72{ }^{\circ} \mathrm{C}$, e uma extensão final a $72{ }^{\circ} \mathrm{C}$ por $10 \mathrm{~min}$. Os produtos das amplificações foram analisados por eletroforese em gel de agarose $1,0 \%$, corados com brometo de etídio (10 $\mathrm{mg} / \mathrm{mL}$ ) e fotografados em fotoducumentador com transluminador. A quadro 3 mostra as sequências do par de iniciadores utilizados nos testes, para amplificação de 326/327 pb do amplicon da região do gene 16S rRNA do U. parvum (DE FRANCESCO et al., 2009). 
Quadro 3 - Sequências dos iniciadores utilizados para amplificação do gene $16 S$ rRNA para U. parvum e peso molecular do produto amplificado.

\begin{tabular}{|ccc|}
\hline Iniciadores & \multicolumn{1}{c|}{ Sequência } & Produto \\
\hline UMS57 & 5' TAAATCTTAGTGTTCATATTTTTTAC 3' & \\
UMA222 & 5' GTAAGTGCAGCATTAAATTCAATG 3' & 326/327 pb \\
\hline
\end{tabular}

\subsubsection{PCR para detecção dos sorotipos da espécie U. parvum}

Para cada Sorotipo de U. parvum foram realizadas diferentes reações, e em cada PCR foi adicionado a um microtubo $(0,2 \mathrm{~mL}), 1 \mathrm{X}$ de Tampão, 20 pmol de cada iniciador, 2,5 U de Taq DNA polimerase (Invitrogen, São Paulo, S.P., Brasil), 25 mM de $\mathrm{MgCl}_{2}, 200 \mu \mathrm{M}$ de deoxiribonucleotídeos trifosfato (dNTP), 3,0 $\mu \mathrm{L}$ da amostra de DNA extraído da amostra clínica e água ultrapura até o volume final de $50 \mu \mathrm{L}$. A amplificação foi realizada em termociclador programado para: um ciclo de $94{ }^{\circ} \mathrm{C}$ por 5 min, 35 ciclos de $94{ }^{\circ} \mathrm{C}$ por $45 \mathrm{~s}, 50^{\circ} \mathrm{C}$ por $45 \mathrm{~s}, 72{ }^{\circ} \mathrm{C}$ por $45 \mathrm{~s}$, um ciclo final de $72{ }^{\circ} \mathrm{C}$ por $10 \mathrm{~min}$ e "hold step" a $4{ }^{\circ} \mathrm{C}$. O quadro 4 mostra as sequências dos iniciadores utilizados nos testes, para amplicons com 398 pb, 442 pb ou 369 pb quando a amostra for positiva para sorotipo 1, sorotipos 3 e 14, e sorotipo 6 do $U$. parvum, respectivamente (DE FRANCESCO et al., 2009). 
Quadro 4 - Sequências dos iniciadores utilizados para amplificação do gene $16 S$ rRNA para Sorotipos do $U$. parvum e peso molecular do produto amplificado.

\begin{tabular}{|c|c|c|}
\hline Iniciadores & Sequência & Produto \\
\hline \multicolumn{3}{|l|}{ Sorotipo 1} \\
\hline UMS 83 & 5' TACTGATAGAAATTATGTAAGATTGC 3' & $398 \mathrm{pb}$ \\
\hline UMA 269A & 5' CCAAATGACCTTTTGTAACTAGAT 3' & \\
\hline \multicolumn{3}{|l|}{ Sorotipo 3 e 14} \\
\hline UMS 125 & 5' GTATTTGCAATCTTTATATGTTTTCG 3' & $442 \mathrm{pb}$ \\
\hline UMA 269B & 5' CTAAATGACCTTTTTCAAGTGTAC 3' & \\
\hline \multicolumn{3}{|l|}{ Sorotipo 6} \\
\hline UMS 54 & 5' CTTAGTGTTCATATTTTTTACTAG 3' & $369 \mathrm{pb}$ \\
\hline UMA 269A & 5' CCAAATGACCTTTTGTAACTAGAT 3' & \\
\hline
\end{tabular}

\subsubsection{PCR para detecção de Neisseria gonorrheae}

Para a amplificação de sequências de Neisseria gonorrheae foram utilizados pares de primers (Quadro 5), para amplificação de $195 \mathrm{pb}$ do amplicon da região do gene 16 S rRNA (MGONE; LUPIWA; YEKA, 2002). A reação foi preparada para um volume final de $50 \mu \mathrm{l} \mathrm{em} \mathrm{microtubo}(0,2 \mathrm{~mL})$, compreendendo: $1 \mathrm{X}$ de Tampão, 100 pmol de cada iniciador, 1,0 U de Taq DNA polimerase (Invitrogen, São Paulo, S.P., Brasil), 1,5 mM de $\mathrm{MgCl}_{2}, 200 \mu \mathrm{M}$ de deoxiribonucleotídeos trifosfato (dNTP) e 1,0 $\mu \mathrm{L}$ da amostra de DNA e água ultrapura. As condições dos PCR foram padronizadas e definidas após realização de testes, sendo a amplificação realizada em termociclador programado para um ciclo de $94{ }^{\circ} \mathrm{C}$ por 5 min, 35 ciclos de $94{ }^{\circ} \mathrm{C}$ por 1 min, $57^{\circ} \mathrm{C}$ por $1 \mathrm{~min}, 72^{\circ} \mathrm{C}$ por $2 \mathrm{~min}$, um ciclo final de $72{ }^{\circ} \mathrm{C}$ por 5 min e hold step a $4{ }^{\circ} \mathrm{C}$. 
Quadro 5 - Sequências dos iniciadores utilizados para amplificação de região gênica específica para detecção de Neisseria gonorrhoeae.

\begin{tabular}{|ccc|}
\hline Iniciadores & Sequência & Produto \\
\hline NG1 & 5' TCTCGACTGGGCAATTTTCC 3' & \\
NG2 & 5' ACGAGGCATTGAAGCAAAGC 3' & $195 \mathrm{pb}$ \\
\hline
\end{tabular}

\subsubsection{PCR para detecção de Gardnerella vaginalis}

Para a amplificação de seqüências de Gardnerella vaginalis foram utilizados pares de primers (Quadro 6), para amplificação de $332 \mathrm{pb}$ do amplicon da região do gene $16 S$ rRNA (ZARFFARD et al., 2002). A reação foi preparada para um volume final de $50 \mu \mathrm{l}$ em microtubo $(0,2 \mathrm{~mL})$, compreendendo: 1X de Tampão, $100 \mathrm{pmol}$ de cada iniciador, 2,0 U de Taq DNA polimerase Invitrogen (Invitrogen, São Paulo, S.P., Brasil), 2,5 mM de $\mathrm{MgCl}_{2}, 200 \mu \mathrm{M}$ de deoxiribonucleotídeos trifosfato (dNTP), 1,0 $\mu \mathrm{L}$ da amostra de DNA e água ultrapura. As condições dos PCR foram padronizadas e definidas após realização de testes, sendo a amplificação realizada em termociclador programado para um ciclo de $94{ }^{\circ} \mathrm{C}$ por $1 \mathrm{~min}, 35$ ciclos de $94{ }^{\circ} \mathrm{C}$ por $15 \mathrm{~s}, 55^{\circ} \mathrm{C}$ por $15 \mathrm{~s}, 72{ }^{\circ} \mathrm{C}$ por $30 \mathrm{~s}$, um ciclo final de $72{ }^{\circ} \mathrm{C}$ por 7 min e "hold step" a $4{ }^{\circ} \mathrm{C}$.

Quadro 6 - Sequências dos iniciadores utilizados para amplificação de região gênica específica para detecção de Gardnerella vaginalis.

\begin{tabular}{|ccc|}
\hline Iniciadores & Sequência & Produto \\
\hline GV1 & 5' TTACTGGTGTATCACTGTAAGG 3' & \\
GV3 & 5' CCGTCACAGGCTGAACAGT 3' & $332 \mathrm{pb}$ \\
\hline
\end{tabular}




\subsubsection{PCR para detecção de Trichomonas vaginalis}

Para a amplificação de seqüências de Trichomonas vaginalis foram utilizados pares de primers (Quadro 7), para amplificação de $120 \mathrm{pb}$ do amplicon da região do gene 16S rRNA (RILEY et al., 1992). A reação foi preparada para um volume final de $50 \mu \mathrm{l}$ em microtubo $(0,2 \mathrm{~mL})$, compreendendo: $1 \mathrm{X}$ de Tampão, foram adicionados 50 pmol de cada iniciador, 2,0 U de Taq DNA polimerase Invitrogen (Invitrogen, São Paulo, S.P., Brasil), 1,5 mM de $\mathrm{MgCl}_{2}, 200 \mu \mathrm{M}$ de deoxiribonucleotídeos trifosfato (dNTP), 1,0 $\mu \mathrm{L}$ da amostra de DNA e água ultrapura. As condições dos PCR foram padronizadas e definidas após realização de testes, sendo a amplificação realizada em termociclador programado para um ciclo de $94{ }^{\circ} \mathrm{C}$ por 5 min, 35 ciclos de $94{ }^{\circ} \mathrm{C}$ por $15 \mathrm{~s}, 47^{\circ} \mathrm{C}$ por $1 \mathrm{~min}, 67^{\circ} \mathrm{C}$ por $1 \mathrm{~min}$, um ciclo final de $67^{\circ} \mathrm{C}$ por $7 \mathrm{~min}$ e "hold step" a $4{ }^{\circ} \mathrm{C}$.

Quadro 7 - Sequências dos iniciadores utilizados para amplificação de região gênica específica para detecção de Trichomonas vaginalis.

\begin{tabular}{|ccc|}
\hline Iniciadores & \multicolumn{1}{c|}{ Sequência } & Produto \\
\hline TVA5 & 5' GATCATGTTCTATCTTTTCA 3' & \\
TVA6 & 5' GATCACCACCTTAGTTTACA 3' & $102 \mathrm{pb}$ \\
\hline
\end{tabular}

\subsubsection{PCR para detecção de Chlamydia trachomatis}

Para a amplificação de seqüências de Chlamydia trachomatis foram utilizados pares de primers (Quadro 8), para amplificação de $241 \mathrm{pb}$ do amplicon da região do gene $16 \mathrm{~S}$ rRNA (MAHONY et al.,1995; MGONE; LUPIWA; YEKA, 2002). A reação foi preparada para um volume final de $50 \mu \mathrm{l}$ em microtubo $(0,2 \mathrm{~mL})$, compreendendo: com 1X de Tampão, $100 \mathrm{pmol}$ de cada iniciador, 1,0 U de Taq DNA polimerase Invitrogen (Invitrogen, São Paulo, S.P., Brasil), 1,5 mM de $\mathrm{MgCl}_{2}, 200 \mu \mathrm{M}$ de deoxiribonucleotídeos trifosfato (dNTP), 2,0 $\mu \mathrm{L}$ da amostra de DNA e água ultrapura. As condições dos PCR foram padronizadas e definidas após realização de testes, sendo a amplificação realizada em termociclador programado para um ciclo de $94{ }^{\circ} \mathrm{C}$ 
por $10 \mathrm{~min}, 35$ ciclos de $94{ }^{\circ} \mathrm{C}$ por $30 \mathrm{~s}, 55^{\circ} \mathrm{C}$ por $30 \mathrm{~s}, 72{ }^{\circ} \mathrm{C}$ por $45 \mathrm{~s}$, um ciclo final de $72{ }^{\circ} \mathrm{C}$ por 10 min e "hold step" a $4{ }^{\circ} \mathrm{C}$.

Quadro 8 - Sequências dos iniciadores utilizados para amplificação de região gênica específica para detecção de Chlamydia trachomatis.

\begin{tabular}{|ccc|}
\hline Iniciadores & Sequência & Produto \\
\hline CT1 & 5' CCTGTGGGGAATCCTGCTGAA 3' & \\
CT4 & 5' GTCGAAAACAAAGTCATCCAGTAGTA 3' & $241 \mathrm{pb}$ \\
\hline
\end{tabular}

\subsection{PCR quantitativo (qPCR)}

\subsubsection{Extração de DNA}

O DNA genômico das amostras de swab vaginal foi obtido segundo protocolo do kit Invitrogen Purelink ${ }^{\mathrm{TM}}$ Genomic DNA Kits (Invitrogen, São Paulo, S.P., Brasil).

\subsection{2 qPCR para detecção de U. urealyticum}

A técnica de PCR em tempo real foi empregada para quantificação do $U$. urealyticum sendo as reações realizadas em duplicata na plataforma Real-Time PCR System 7300 Applied Biosystems e com a utilização de Sondas TaqMan, seguindo protocolo base de amplificação do fabricante.

A reação de PCR em tempo real consistiu em 12,5 $\mu \mathrm{L}$ de Master Mix (Applied Biosystems, São Paulo, S.P., Brasil), $0,75 \mu \mathrm{L}$ de primer UUureF (ATCGACGTTGCCCAA GGGGA), 0,75 $\mu \mathrm{L}$ de primer UUureR (TTAGCACCAACATAAGGAGCTAAATC) (10 pmol), 0,5 $\mu \mathrm{L}$ de sonda (FAMTTGTCCGCCTTTACGAG-MGB) (5 mM), 9,5 $\mu \mathrm{L}$ de água e 1,0 $\mu \mathrm{L}$ de DNA em quantidades suficientes para um volume final de $25 \mu \mathrm{L}$. As amostras foram submetidas a amplificação nas seguintes condições de termo-ciclagem: $50{ }^{\circ} \mathrm{C}$ por 2 min, $95{ }^{\circ} \mathrm{C}$ por $10 \mathrm{~min}$, seguidos de 40 ciclos de $95{ }^{\circ} \mathrm{C}$ por $15 \mathrm{~s}$ e $58{ }^{\circ} \mathrm{C}$ por $30 \mathrm{~s}$ (CAO et al., 2007). 


\subsection{3 qPCR para detecção de U. parvum}

A reação de PCR em tempo real consistiu em 12,5 $\mu \mathrm{L}$ de Master Mix (Applied Biosystems, São Paulo, S.P., Brasil), $0,75 \mu \mathrm{L}$ de primer UUureF (CATTGATGTTGCACAAGGAGAAA), $0,75 \mu \mathrm{L}$ de primer UUureR (TTAGCACCAACATAAGGAGCTAAATC) $(10 \mathrm{pmol}), 0,5 \mu \mathrm{L}$ de sonda (FAMTTGACCACCCTTACGAG-MGB) (5 mM), 9,5 $\mu \mathrm{L}$ de água e 1,0 $\mu \mathrm{L}$ de DNA em quantidades suficientes para um volume final de $25 \mu \mathrm{L}$. As amostras foram submetidas a amplificação nas seguintes condições de termo-ciclagem: $50{ }^{\circ} \mathrm{C}$ por 2 min, $95{ }^{\circ} \mathrm{C}$ por $10 \mathrm{~min}$, seguidos de 40 ciclos de $95^{\circ} \mathrm{C}$ por $15 \mathrm{~s}$ e $58^{\circ} \mathrm{C}$ por $30 \mathrm{~s}$ (CAO et al., 2007).

\subsubsection{Análise dos dados da qPCR}

A quantificação foi realizada por meio de técnica de quantificação absoluta, tomando por base uma curva padrão pré-estabelecida variando de $10^{7}$ a $10^{0}$ microrganismos/ $\mu \mathrm{L}$ (Figura 2). A cada reação uma nova curva foi adicionada, sendo estabelecidas para uma boa análise as seguintes características: $r^{2} \geq 0.950$ e eficiência entre 95 a 105\% e slope próximo de 3.32 .

A análise dos dados gerados foi feita com o auxílio do software StepOne ${ }^{T M}$ software v2.1 (Applied Biosystems). Por meio deste software determinou-se o threshold, ou limiar de detecção, de cada amostra testada. O threshold corresponde a um ponto de referência, uma vez que neste ponto todas as amostras possuem a mesma intensidade de fluorescência. Uma vez determinado o threshold, foi estabelecido o número de $\mathrm{Ct}$ de cada amostra. O número de $\mathrm{Ct}$ serve como base de comparação entre as amostras, pois se refere ao número de ciclo no qual a curva de amplificação de cada amostra atinge o threshold estabelecido. 
Figura 2 - Gráficos gerados a partir da reação de PCR em tempo real para determinação da curva padrão utilizada nos testes para a espécie $U$. urealyticum.
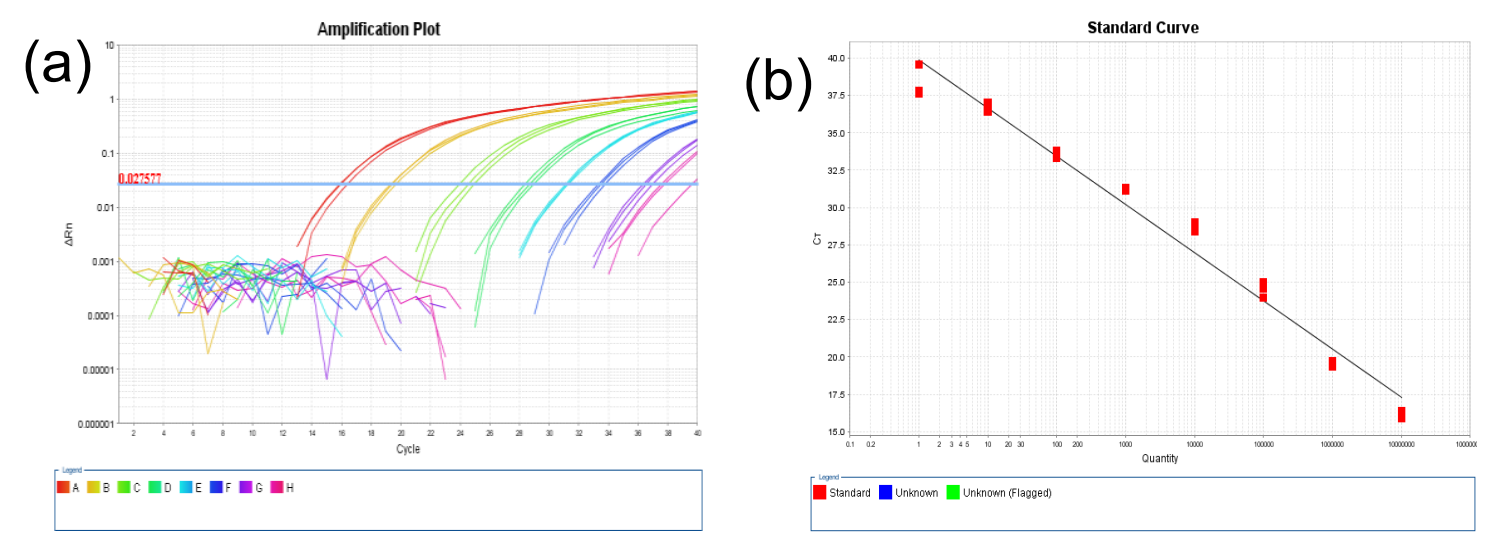

Legenda: (a) Amplificação de cada amostra de DNA de U. urealyticum da curva padrão, diluída em razão 1:10. (b) Curva padrão gerada a partir dos pontos de Ct obtidos com o gráfico de amplificação.

\subsection{Polimorfismo de citocinas}

\subsubsection{Extração de DNA das amostras de sangue}

Foram utilizadas para extração de DNA amostras de sangue, homogeneizadas, em tubos vacutainer contendo EDTA $(1000 \mu \mathrm{L})$ baseado no protocolo de extração sugerido pelo fabricante do Kit Invitek Invisorb - Spin Blood Midi/ Maxi Kit 1209 (Stratec molecular, São Paulo, S.P., Brasil). As amostras de DNA extraídas foram aliquotadas $(200 \mu \mathrm{L})$ em microtubos e estocadas em $-20{ }^{\circ} \mathrm{C}$.

\subsubsection{MS-PCR para detecção do polimorfismo $c-174 G>C$ no gene IL-6}

A MS-PCR é uma técnica de PCR direcionada à identificação de mutações alélicas baseada nas sequências de ácidos nucleicos. O princípio básico do método é a introdução de mutações nas regiões de ligação dos inicadorees da PCR nos amplicons, a partir de diferentes distâncias da extremidade 3'. Nos ciclos subsequentes as mutações previnem a formação de produtos errados da elongação por conta da ligação específicas de cada primer (RUST, et al., 1993). Para detecção do polimorfismo -174 G>C da citocina IL-6 foram utilizados iniciadores específicos 
(IL-6G, IL-6C e IL6GSP) para a região -174 do cromossomo. O quadro 9 resume os dados dos iniciadores utilizados na reação.

Quadro 9 - Sequências dos iniciadores utilizados para detecção de polimorfismo monogenético na região -174 do cromossomo que codifica a IL-6 e peso molecular do produto amplificado.

\begin{tabular}{|ccc|}
\hline Iniciadores & Sequência & Produto \\
\hline IL-6G & 5' GCACTTTTCCCCCTAGTTGTGTCTTACG 3' & $121 \mathrm{pb}$ \\
IL-6C & 5' ATGACGACCTAAGCTTTACTTTTCC & $136 \mathrm{pb}$ \\
& CCCTAGTTGTGTCTTGAC 3' & \\
IL-6GSP & 5 ATAAATCTTTGTTGGAGGGTGAGG 3' & - \\
\hline
\end{tabular}

A reação de MS-PCR consistiu em1X de Tampão, 100 pmol de cada iniciador, 1,0 U de Taq DNA polimerase (Invitrogen, São Paulo, S.P., Brasil), 1,0 mM de $\mathrm{MgCl}_{2}, 200 \mu \mathrm{M}$ de deoxiribonucleotídeos trifosfato (dNTP), 6,0 $\mu \mathrm{L}$ da amostra de DNA e água ultrapura em quantidades suficientes para um volume final de $50 \mu \mathrm{L}$. As amostras foram submetidas a amplificação nas seguintes condições de termociclagem:: um ciclo de $94{ }^{\circ} \mathrm{C}$ por $7 \mathrm{~min}, 45$ ciclos de $94{ }^{\circ} \mathrm{C}$ por $45 \mathrm{~s}, 57,3{ }^{\circ} \mathrm{C}$ por 1 min e $15 \mathrm{~s}, 72{ }^{\circ} \mathrm{C}$ por $1 \mathrm{~min}$ e $15 \mathrm{~s}$, um ciclo final de $72{ }^{\circ} \mathrm{C}$ por $7 \mathrm{~min}$ e hold step a 4 ${ }^{\circ} \mathrm{C}$ (SCHOTTE et al., 2001).

\subsubsection{PCR RFLP para detecção do polimorfismo c-+3954 C>T no gene IL-1 $\beta$}

Foram avaliadas por PCR convencional e digestão a região +3954 da IL-1 $\beta$ onde ocorre o polimorfismo. A PCR foi preparada para um volume final de $50 \mu \mathrm{l} \mathrm{em}$ microtubo (0,2 $\mathrm{mL})$, compreendendo: $1 \mathrm{X}$ de Tampão, 10 pmol de cada iniciador, 1,0 $U$ de Taq DNA polimerase (Invitrogen, São Paulo, S.P., Brasil), 1,0 mM de $\mathrm{MgCl}_{2}$, $200 \mu \mathrm{M}$ de deoxiribonucleotídeos trifosfato (dNTP), 7,0 $\mu \mathrm{L}$ da amostra de DNA e água ultrapura até o volume final de $50 \mu \mathrm{L}$. A amplificação foi realizada em termociclador programado para: um ciclo de $94{ }^{\circ} \mathrm{C}$ por $5 \mathrm{~min}, 40$ ciclos de $94{ }^{\circ} \mathrm{C}$ por $1 \mathrm{~min}, 61,5^{\circ} \mathrm{C}$ por $1 \mathrm{~min}, 72{ }^{\circ} \mathrm{C}$ por $1 \mathrm{~min}$, um ciclo final de $72{ }^{\circ} \mathrm{C}$ por $7 \mathrm{~min}$ e hold 
step a $4{ }^{\circ} \mathrm{C}$. Para a amplificação das sequências foram utilizados pares de primers (Quadro 10), para amplificação do produto de 182 pb detectada em eletroforese com gel de agarose a $1 \%$ (AGRAWAL et al., 2006).

Quadro 10 - Sequências dos iniciadores utilizados para amplificação de região gênica específica em que ocorre mutação monogênica para IL-1ß e peso molecular do produto amplificado.

\begin{tabular}{|ccc|}
\hline Iniciadores & Sequência & Produto \\
\hline P1 & 5' CTCAGGTGTCCTCGAAGAAATCAAA 3" & \\
P2 & 5' GCTTTTTTTGCTGTGAGTCCCG 3' & 182pb \\
\hline
\end{tabular}

As amostras com produtos amplificados foram submetidas à digestão com enzima de restrição Taql (New England Biolabs, Beverly, M. A., Estados Unidos) com intuito de se obter a distribuição dos alelos. Para tal, utilizou-se microtubos de $0,2 \mu \mathrm{L}$ contendo a mistura da reação com: $2,5 \mathrm{mM}$ de Tampão, $0,13 \mu \mathrm{L}$ da enzima Taql, 15,0 $\mu \mathrm{L}$ de DNA e água ultrapura até o volume final de $50 \mu \mathrm{L}$. A digestão foi realizada em termociclador programado para um ciclo de $64{ }^{\circ} \mathrm{C}$ overnight. $\mathrm{O}$ produto da digestão foi submetido à eletroforese em gel de agarose a $4 \%$ com brometo de etídio em 110V.

\subsubsection{Confirmação do polimorfismo genético dos genes IL-6 e IL-1ß por sequenciamento}

Após a realização das PCRs, os produtos amplificados, evidenciados no gel por meio da luz ultravioleta, foram recortados diretamente do gel e submetidos ao processo de purificação realizada através do kit comercial Qiagen - QIAquick Gel extraction Kit (Qiagen, Chatsworth, C.A., Estados Unidos) seguindo as instruções do fabricante. $O$ produto amplificado de cada PCR foi sequenciado utilizando a plataforma Sanger ABI 3700 do Genomics Core Facility localizado na Purdue University, Estados Unidos. As sequências obtidas foram comparadas com os genes de referência descritos para IL-6 e IL-1 $\beta$ na base de dados do National Center for Biotechnology Information (NCBI). 


\subsection{Dosagem das citocinas IL-6 e IL-1 $\beta$ no soro}

A dosagem das citocinas IL-6 e IL-1 $\beta$ foram realizadas utilizando-se kit de ELISA (eBioscience, San Diego, C. A., Estados Unidos) e placas de 96 poços de poliestireno que confere alta absorção de acordo com protocolo indicado pelo fabricante. Após padronização da curva padrão e do volume mais adequado para as amostra, uma alíquota de $100 \mu \mathrm{L}$ do soro das mulheres foi utilizada para dosar a citocina IL-1ß. A leitura foi realizada com instrumento leitor de ELISA Vivid Vision com comprimento de onda de $450 \mathrm{~nm}$. Os dados obtidos em absorbância foram transformados em picomols por meio de fórmula matemática.

\subsection{Análise estatística}

As análises estatísticas dos questionários foram realizadas através do software SPSS $16.0^{\circledR}$ (SPSS Inc., Chicago, Estados Unidos). Para verificação de associação entre variáveis foi aplicado Teste de qui-quadrado de Pearson ou Teste Exato de Fisher tendo sido considerado $p<0,05$ e IC 95\%. O Odds Ratio (OR) foi calculado em análise univariada para estimar o poder de associação entre a presença de infecção vaginal, com fatores de risco como dados demográficos e de saúde sexual das mulheres. Também utilizou-se a Análise multivariada por regressão logística para determinar quais variáveis foram independentemente associadas com infecção.

Em relação aos polimorfismos genéticos e quantificação das citocinas foi utilizado o programa GraphPadPrism $5.01^{\circledR}$ com os testes não-paramétricos Kruskall-Wallis e Mann-Whitney. 


\section{RESULTADOS}

\subsection{PCR para detecção de Ureaplasma}

Das 302 mulheres deste estudo, um total de 230 (76,2\%) foram positivas para a presença de Mollicutes por meio da PCR genérica convencional. Estas amostras positivas foram submetidas a PCR específica para Ureaplasma (Tabela 1), e revelou que a prevalência de $U$. urealyticum e $U$. parvum foi $7,0 \%$ e $52,0 \%$, respectivamente. Os produtos amplificados nas reações de PCR para Mollicutes, $U$. urealyticum e $U$. parvum, podem ser visualizados, respectivamente, nas Figuras 3, 4 e 5 . Seis mulheres apresentaram co-infecção com ambas as espécies de ureaplasma.

Tabela 1 - Perfil de detecção de Mollicutes, U. urealyticum e U. parvum, por meio da PCR convencional, em amostras de swab vaginal de mulheres atendidas em Unidades de Saúde de Vitória da Conquista - BA, 2011.

\begin{tabular}{cccc}
\hline PCR & PCR Genérica & U. urealyticum & U. parvum \\
\cline { 2 - 4 } & $\mathbf{n}(\%)$ & $\mathbf{n}(\%)$ & $\mathbf{n}(\%)$ \\
\hline Positiva & $230(76,2)$ & $21(7,0)$ & $157(52,0)$ \\
Negativa & $72(23,8)$ & $281(93,0)$ & $145(48,0)$ \\
\hline
\end{tabular}

Nota: $\mathrm{n}=302$ amostras. 
Figura 3 - Eletroforese em gel de agarose dos produtos da PCR utilizando "primers" genéricos GPO3 e MGSO para detecção de Mollicutes.

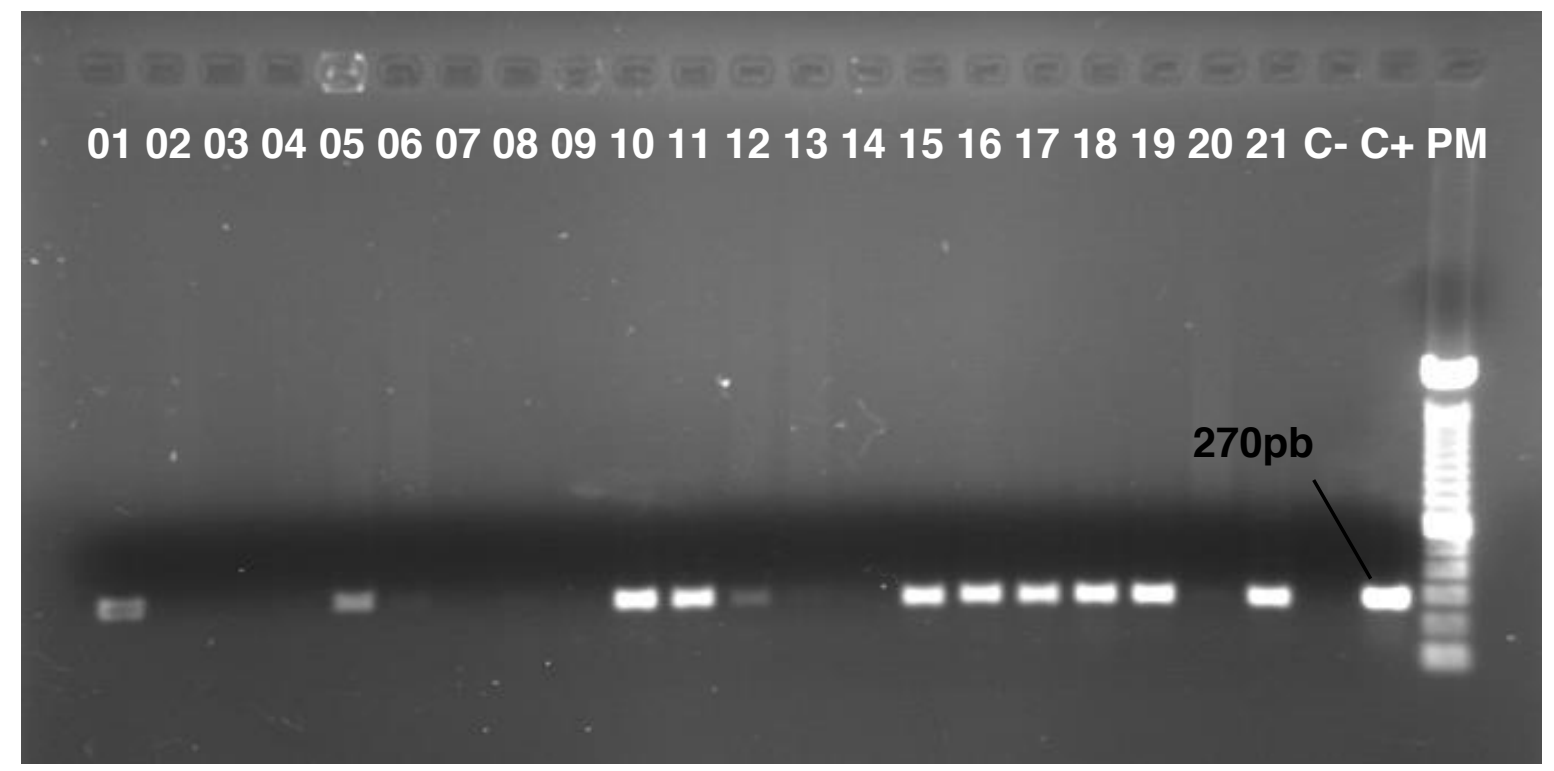

Legenda: Colunas 1, 5, 10, 11, 12, 15, 16, 17, 18, 19 e 21: amostras amplificadas; Legenda: C-: Controle Negativo; C+: Controle Positivo (U. urealyticum); PM: Peso Molecular (100 pb).

Figura 4 - Eletroforese em gel de agarose dos produtos amplificados na PCR utilizando "primers" MS170 e UMA263 para detecção de $U$. urealyticum.

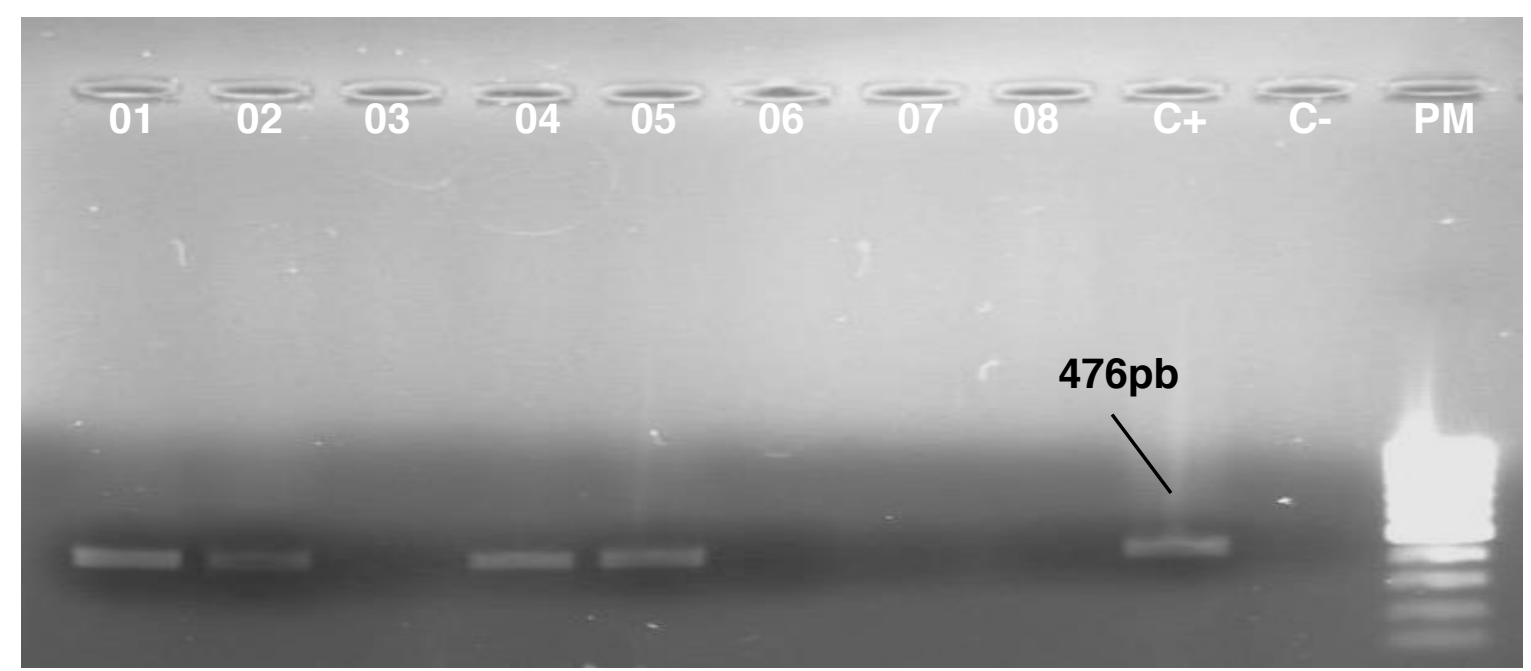

Legenda: Colunas 01, 02, 04, 05: amostras amplificadas; Legenda: C+: Controle Positivo (U. urealyticum); C-: Controle Negativo; PM: Peso Molecular (100 pb). 
Figura 5 - Eletroforese em gel de agarose dos produtos amplificados na PCR utilizando "primers" UMS57 e UMA222 para detecção de U. parvum.

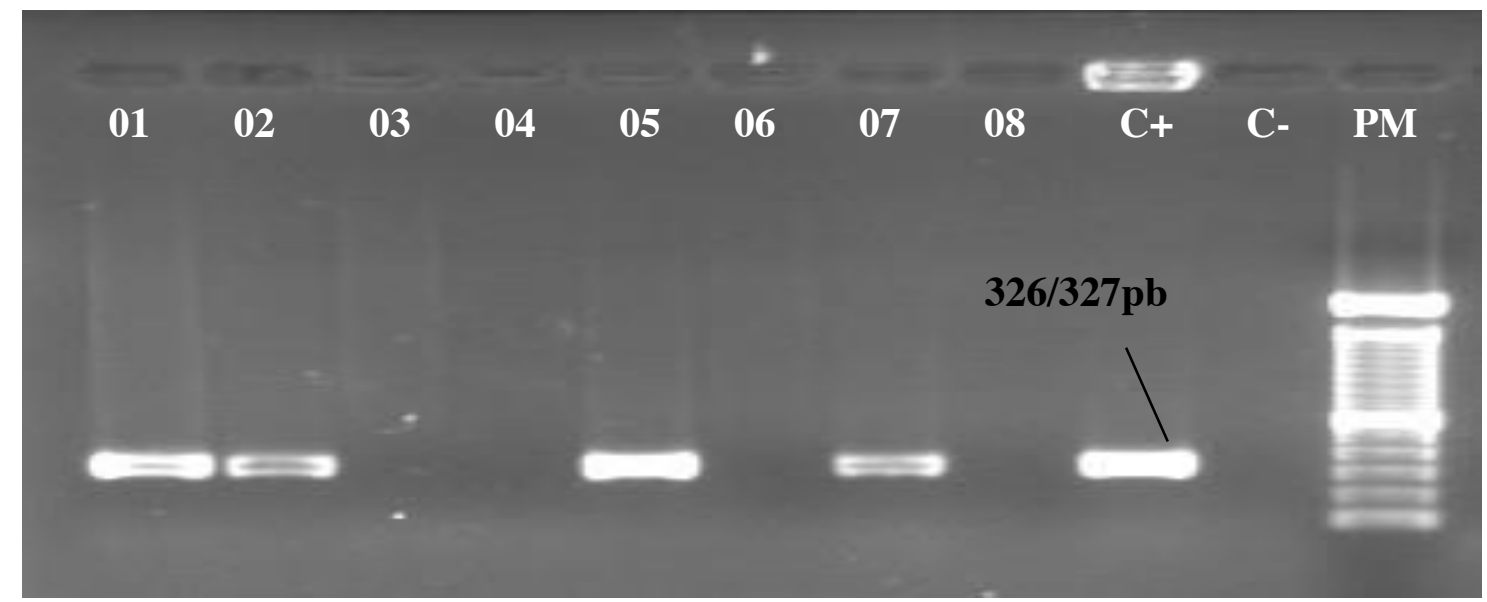

Legenda: Colunas 01, 02, 05 e 07: amostra amplificada; Legenda: C+: Controle Positivo (U. parvum); C-: Controle Negativo; PM: Peso Molecular (100 pb);

\subsection{PCR para detecção dos sorotipos de U. parvum}

As amostras positivas para $U$. parvum foram subtipadas nos diferentes sorotipos. Os sorotipos 6 , e $3 / 14$ foram os mais frequentes, $64(40,8 \%)$, e 62 $(39,5 \%)$, respectivamente. Seguidos do sorotipo 1 , com $37(23,6 \%)$ amostras positivas (Tabela 2). Em 18 amostras vaginais encontrou-se co-infecção de dois ou mais sorotipos e uma amostra positiva para U. parvum não foi sorotipada.

Tabela 2 - Perfil de detecção dos sorotipos de U. parvum, por meio da PCR convencional, em amostras de swab vaginal de mulheres atendidas em Unidades de Saúde de Vitória da Conquista - BA, 2011.

\begin{tabular}{cccc}
\hline \multirow{2}{*}{ PCR } & $\begin{array}{c}\text { U. parvum } \\
\text { Sorotipo 1 }\end{array}$ & $\begin{array}{c}\text { U. parvum } \\
\text { Sorotipo 3 e 14 }\end{array}$ & $\begin{array}{c}\text { U. parvum } \\
\text { Sorotipo 6 }\end{array}$ \\
\cline { 2 - 4 } & $\mathbf{n ~ ( \% )}$ & $\mathbf{N ~ ( \% )}$ & $\mathbf{n}(\%)$ \\
\hline Positiva & $37(23,6)$ & $62(39,5)$ & $64(40,8)$ \\
Negativa & $120(76,4)$ & $95(60,5)$ & $93(59,2)$ \\
\hline
\end{tabular}

Nota: $\mathrm{n}=157$ amostras. 


\section{3 qPCR para detecção de Ureaplasmas}

A tabela 3 mostra a prevalência de $16,6 \%$ para $U$. urealyticum e de $60,6 \%$ para U. parvum, nas amostras de swab genital das mulheres participantes do estudo.

Tabela 3 - Perfil de detecção de U. urealyticum e U. parvum, por meio da qPCR em amostras de swab vaginal de mulheres atendidas em Unidades de Saúde de Vitória da Conquista - BA, 2011.

\begin{tabular}{ccc}
\hline \multirow{2}{*}{ qPCR } & U. urealyticum & U. parvum \\
\cline { 2 - 3 } & $\mathbf{n}(\%)$ & $\mathbf{n}(\%)$ \\
\hline Positiva & $50(16,6)$ & $183(60,6)$ \\
Negativa & $252(83,4)$ & $119(39,4)$ \\
\hline
\end{tabular}

Nota: $\mathrm{n}=302$ amostras.

Por meio da qPCR foi possível quantificar o DNA e consequentemente a carga do microrganismo representada por unidades formadoras de colônias (UFC/ $\mu \mathrm{L}$ ) nas amostras de swab vaginal. Na Figura 6a apresenta as detecções de aproxidamente $10^{4}$ a $10^{\circ} \mathrm{UFC} / \mu \mathrm{L}$ de $U$. urealyticum. Contudo, as médias das dosagens, foram maiores nas mulheres do grupo controle $(p=0,0339)$. Encontrouse maior carga de $U$. parvum entre as amostras (101 a $\left.10^{7} \mathrm{UFC} / \mu \mathrm{L}\right)$, porém não houve diferença estatisticamente significante entre as mulheres dos grupos caso e controle $(p=0,8892)$ (Figura 6b). 
Figura 6 - Quantificação por qPCR, de $U$. urealyticum e $U$. parvum (UFC/ $\mu \mathrm{L}$ ) a partir das amostras de swab vaginal, nos grupos caso e controle.

(a)

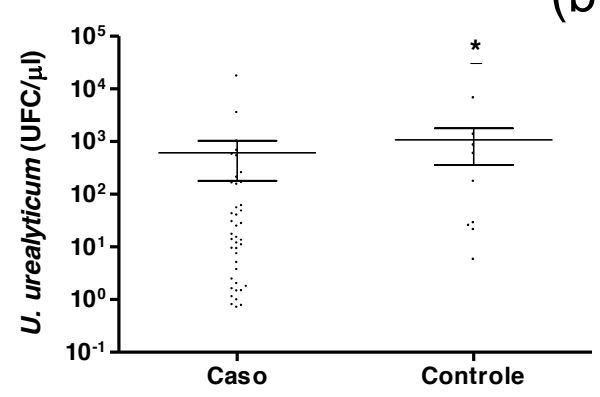

(b)

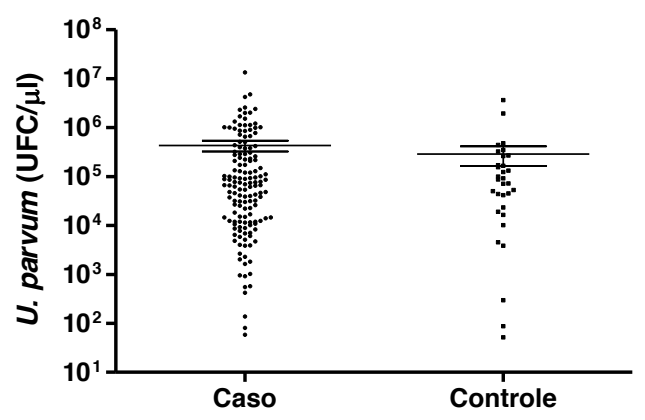

Legenda: (a) Concentração de U. urealyticum (UFC/ $\mu \mathrm{L}$ ) entre as mulheres dos grupos caso e controle. (b) Concentração de $U$. parvum (UFC/ $\mu \mathrm{L}$ ) entre as mulheres dos grupos caso e controle. Desvio padrão e média indicados por linhas sólidas no gráfico. Análise estatística realizada por Mann Whitney. $p<0,05$.

\subsection{PCR para detecção de outros microrganismos de importância ginecológica}

Entre os outros agentes causadores de infecções no trato genital feminino, $G$. vaginalis foi o microrganismo mais frequente entre as 302 mulheres participantes do estudo, e foi detectado em $42,4 \%$ das amostras de swab genital, seguido por $N$. gonorrhoeae $(21,5 \%), T$. vaginalis $(3,0 \%)$ e $C$. trachomatis $(1,7 \%)$ (Tabela 4$)$.

Entre a 50 mulheres positivas na qPCR para $U$. urealyticum, quatro $(8,0 \%)$ apresentaram co-infecção com $T$. vaginalis, nove $(18,0 \%)$ com $N$. gonorrhoeae, 25 $(50,0 \%)$ com $G$. vaginalis e uma $(2,0 \%)$ com $C$. trachomatis. E entre as 183 mulheres positivas na qPCR para $U$. parvum, em nove $(4,9 \%)$ encontrou-se co-infecção com T. vaginalis, $40(21,9 \%)$ com $N$. gonorrhoeae, $82(44,8 \%)$ com G. vaginalis e 4 $(2,2 \%)$ com C. trachomatis. 
Tabela 4 - Perfil de detecção dos microrganismos Trichomonas vaginalis, Neisseria gonorrhoeae, Gardnerella vaginalis, e Chlamydia trachomatis em amostras de swab vaginal testadas por meio da PCR convencional, em mulheres atendidas em Unidades de Saúde de Vitória da Conquista - Ba, 2011.

\begin{tabular}{ccccc}
\hline \multirow{2}{*}{ PCR } & $\begin{array}{c}\text { Trichomonas } \\
\text { vaginalis }\end{array}$ & $\begin{array}{c}\text { Neisseria } \\
\text { Gonorrhoeae }\end{array}$ & $\begin{array}{c}\text { Gardnerella } \\
\text { vaginalis }\end{array}$ & $\begin{array}{c}\text { Chlamydia } \\
\text { trachomatis }\end{array}$ \\
\cline { 2 - 5 } & $\mathbf{n}(\%)$ & $\mathbf{n}(\%)$ & $\mathbf{n}(\%)$ & $\mathbf{n}(\%)$ \\
\hline Positiva & $9(3,0)$ & $65(21,5)$ & $128(42,4)$ & $5(1,7)$ \\
Negativa & $293(97,0)$ & $237(78,5)$ & $174(57,6)$ & $297(98,3)$ \\
\hline
\end{tabular}

Nota: $\mathrm{n}=302$ amostras.

\subsection{Caracterização do perfil demográfico e da saúde sexual das mulheres}

5.5.1 Perfil das mulheres com a presença de Mollicutes, U. urealyticum e U. parvum nas amostras de swab vaginal

A distribuição das mulheres que apresentaram Mollicutes, $U$. urealyticum e $U$. parvum genital, pode ser vista na Tabela 5 . Esses microrganismos foram mais frequentes em mulheres da região urbana, com idade superior ou igual a 25 anos, que declaravam-se de cor preta, parda ou indígena, tinham relacionamento estável com o parceiro, e que não completaram o ensino médio.

Essas mulheres eram sexualmente ativas, referiram menarca até os 15 anos de idade. $O$ início da atividade sexual ocorreu com idade superior a 15 anos, tiveram menos de cinco parceiros na vida e um ou mais parceiros nos últimos três meses. Quanto a prática do sexo seguro, as mulheres relatam o uso raro ou ocasional do condom nas relações sexuais. A prática contraceptiva mais comum foi o uso dos métodos anticoncepcionais hormonais, como a pílula, os injetáveis, anel vaginal e o DIU com levonorgestrel.

As variáveis, dispaurenia, sinusiorragia, disúria, dor pélvica, prurido e corrimento, relacionadas com os sinais e sintomas de infecção do trato genital, apresentaram variações entre as mulheres infectadas pelas diferentes espécies de ureaplasma. 
Tabela 5 - Perfil das mulheres com resultado de PCR e qPCR positivo para Mollicutes, $U$. urealyticum e $U$. parvum, atendidas em unidades de saúde de Vitória da Conquista - BA, 2011.

(Continua)

\begin{tabular}{|c|c|c|c|c|c|}
\hline \multirow{3}{*}{ Variáveis } & $\begin{array}{c}\text { Mollicutes } \\
\text { PCR Genérico-Positivo }\end{array}$ & $\begin{array}{l}\text { U. urealyticum } \\
\text { PCR-Positivo }\end{array}$ & $\begin{array}{l}\text { U. urealyticum } \\
\text { qPCR-Positivo }\end{array}$ & $\begin{array}{c}\text { U. parvum } \\
\text { PCR-Positivo }\end{array}$ & $\begin{array}{c}\text { U. parvum } \\
\text { qPCR-Positivo }\end{array}$ \\
\hline & $\mathrm{N}=\mathbf{2 3 0}$ & $\mathrm{N}=\mathbf{2 1}$ & $\mathrm{N}=50$ & $\mathrm{~N}=157$ & $N=183$ \\
\hline & n (\%) & n (\%) & n (\%) & $n(\%)$ & $n(\%)$ \\
\hline \multicolumn{6}{|l|}{ Dados Demográficos } \\
\hline \multicolumn{6}{|l|}{ Região } \\
\hline Rural & $63(27,4)$ & $9(42,9)$ & $21(42,0)$ & $41(26,1)$ & $48(26,2)$ \\
\hline Urbana & $167(72,6)$ & $12(57,1)$ & $29(58,0)$ & $116(73,9)$ & $135(73,8)$ \\
\hline \multicolumn{6}{|l|}{ Motivo da Consulta ${ }^{1}$} \\
\hline Sintomático & $64(28,3)$ & $7(35,0)$ & $17(34,7)$ & $45(29,2)$ & $53(29,4)$ \\
\hline Rotina & $162(71,7)$ & $13(65,0)$ & $32(65,3)$ & $109(70,8)$ & $127(70,6)$ \\
\hline \multicolumn{6}{|l|}{ Idade } \\
\hline$<25$ anos & $42(18,3)$ & $6(28,6)$ & $11(22,0)$ & $30(19,1)$ & $34(18,6)$ \\
\hline$\geq 25$ anos & $188(81,7)$ & $15(71,4)$ & $39(78,0)$ & $127(80,9)$ & $149(81,4)$ \\
\hline \multicolumn{6}{|l|}{ Raça/Cor } \\
\hline Preta/Parda/Indígena & $172(74,8)$ & $18(85,7)$ & $41(82,0)$ & $123(78,3)$ & $140(76,5)$ \\
\hline Branca/Amarela & $58(25,2)$ & $3(14,3)$ & $9(18,0)$ & $34(21,7)$ & $43(23,5)$ \\
\hline \multicolumn{6}{|l|}{ Escolaridade $^{2}$} \\
\hline < Ensino Médio & $161(73,9)$ & $13(68,4)$ & $38(79,2)$ & $105(70,9)$ & $128(73,6)$ \\
\hline$\geq$ Ensino Médio & $57(26,1)$ & $6(31,6)$ & $10(20,8)$ & $43(29,1)$ & $46(26,4)$ \\
\hline \multicolumn{6}{|l|}{ Relação estável } \\
\hline Não & $41(17,8)$ & $2(9,5)$ & $6(12,0)$ & $32(20,4)$ & $36(19,7)$ \\
\hline Sim & $189(82,2)$ & $19(90,5)$ & $44(88,0)$ & $125(79,6)$ & $147(80,3)$ \\
\hline \multicolumn{6}{|l|}{ Menarca } \\
\hline$<15$ anos & $176(76,5)$ & $17(81,0)$ & $41(82,0)$ & $121(77,1)$ & $143(78,1)$ \\
\hline$\geq 15$ anos & $54(23,5)$ & $4(19,0)$ & $9(18,0)$ & $36(22,9)$ & $40(21,9)$ \\
\hline \multicolumn{6}{|l|}{ Saúde Sexual } \\
\hline \multicolumn{6}{|l|}{ Primeira relação sexual } \\
\hline$\leq 15$ anos & $54(23,5)$ & $7(33,3)$ & $15(30,0)$ & $34(21,7)$ & $42(23,0)$ \\
\hline$>15$ anos & $176(76,5)$ & $14(66,7)$ & $35(70,0)$ & $123(78,3)$ & $141(77,0)$ \\
\hline \multicolumn{6}{|l|}{ Vida Sexual ${ }^{3}$} \\
\hline Ativa & $217(94,3)$ & $21(100)$ & $49(98,0)$ & $149(94,9)$ & $174(95,1)$ \\
\hline Inativa & $13(5,7)$ & 0 & $1(2,0)$ & $8(5,1)$ & $9(4,9)$ \\
\hline \multicolumn{6}{|l|}{ Libido $^{4}$} \\
\hline Diminuída & $100(43,9)$ & $9(42,9)$ & $19(38,0)$ & $67(43,2)$ & $81(44,8)$ \\
\hline Mantida & $128(56,1)$ & $12(57,1)$ & $31(62,0)$ & $88(56,8)$ & $100(55,2)$ \\
\hline \multicolumn{6}{|l|}{ Parceiros na Vida ${ }^{5}$} \\
\hline$\geq 5$ & $21(9,1)$ & $4(19,0)$ & $7(14,0)$ & $18(11,5)$ & $19(10,4)$ \\
\hline$<5$ & $209(90,9)$ & $17(81,0)$ & $43(86,0)$ & $139(88,5)$ & $164(89,6)$ \\
\hline \multicolumn{6}{|l|}{ Parceiros últimos 3 meses $^{6}$} \\
\hline$\geq 1$ & $210(92,1)$ & $21(100)$ & $48(98,0)$ & $144(92,9)$ & $169(93,4)$ \\
\hline Nenhum & $18(7,9)$ & 0 & $1(2,0)$ & $11(7,1)$ & $12(6,6)$ \\
\hline
\end{tabular}


Tabela 5 - Perfil das mulheres com resultado de PCR e qPCR positivo para Mollicutes, $U$. urealyticum e $U$. parvum, atendidas em unidades de saúde de Vitória da Conquista - BA, 2011.

(Conclusão)

\begin{tabular}{|c|c|c|c|c|c|}
\hline \multirow[t]{3}{*}{ Variáveis } & $\begin{array}{c}\text { Mollicutes } \\
\text { PCR Genérico-Positivo }\end{array}$ & $\begin{array}{l}\text { U. urealyticum } \\
\text { PCR-Positivo }\end{array}$ & $\begin{array}{l}\text { U. urealyticum } \\
\text { qPCR-Positivo }\end{array}$ & $\begin{array}{c}\text { U. parvum } \\
\text { PCR-Positivo }\end{array}$ & $\begin{array}{c}\text { U. parvum } \\
\text { qPCR-Positivo }\end{array}$ \\
\hline & $N=230$ & $\mathrm{~N}=\mathbf{2 1}$ & $\mathrm{N}=\mathbf{5 0}$ & $\mathrm{N}=157$ & $\mathrm{~N}=\mathbf{1 8 3}$ \\
\hline & n (\%) & $\mathrm{N}(\%)$ & n (\%) & $n(\%)$ & $n(\%)$ \\
\hline \multicolumn{6}{|l|}{ Uso de Condom ${ }^{7}$} \\
\hline Raro/Ocasional & $174(78,0)$ & $18(85,7)$ & $36(72,0)$ & $118(77,6)$ & $138(78,0)$ \\
\hline Sempre & $49(22,0)$ & $3(14,3)$ & $14(28,0)$ & $34(22,4)$ & $39(22,0)$ \\
\hline \multicolumn{6}{|c|}{ Contracepção Hormonal ${ }^{8}$} \\
\hline Sim & $140(61,9)$ & $11(52,4)$ & $30(60,0)$ & $98(63,6)$ & $112(62,6)$ \\
\hline Não & $86(38,1)$ & $10(47,6)$ & $20(40,0)$ & $56(36,4)$ & $67(37,4)$ \\
\hline \multicolumn{6}{|l|}{ Dispareunia $^{9}$} \\
\hline Sim & $75(33,3)$ & $6(28,6)$ & $18(36,0)$ & $54(35,3)$ & $61(34,1)$ \\
\hline Não & $150(66,7)$ & $15(71,4)$ & $32(64,0)$ & $99(64,7)$ & $118(65,9)$ \\
\hline \multicolumn{6}{|l|}{ Sinusiorragia ${ }^{10}$} \\
\hline Sim & $20(8,8)$ & $1(4,8)$ & $5(10,0)$ & $13(8,4)$ & $16(8,9)$ \\
\hline Não & $206(91,2)$ & $20(95,2)$ & $45(90,0)$ & $141(91,6)$ & $164(91,1)$ \\
\hline \multicolumn{6}{|l|}{ Disúria } \\
\hline Sim & $49(21,3)$ & $4(19,0)$ & $11(22,0)$ & $38(24,2)$ & $42(23,0)$ \\
\hline Não & $181(78,7)$ & $17(81,0)$ & $39(78,0)$ & $119(75,8)$ & $141(77,0)$ \\
\hline \multicolumn{6}{|l|}{ Dor Pélvica } \\
\hline Sim & $105(45,7)$ & $12(57,1)$ & $\begin{array}{l}24(48,0) \\
26(52,0)\end{array}$ & $76(48,4)$ & $87(47,5)$ \\
\hline Não & $125(54,3)$ & $9(42,9)$ & & $81(51,6)$ & $96(52,5)$ \\
\hline \multicolumn{6}{|l|}{ Prurido } \\
\hline Sim & $69(30,0)$ & $8(38,1)$ & $18(36,0)$ & $54(34,4)$ & $61(33,3)$ \\
\hline Não & $161(70,0)$ & $13(61,9)$ & $32(64,0)$ & $103(65,6)$ & $122(66,7)$ \\
\hline \multicolumn{6}{|l|}{ Corrimento ${ }^{11}$} \\
\hline Sim & $106(46,3)$ & $9(42,9)$ & $24(48,0)$ & $77(49,4)$ & $89(48,9)$ \\
\hline Não & $123(53,7)$ & $12(57,1)$ & $26(52,0)$ & $79(50,6)$ & $93(51,1)$ \\
\hline \multicolumn{6}{|l|}{ Sinais e Sintomas ${ }^{12}$} \\
\hline Sim & $185(80,8)$ & $16(76,2)$ & $41(82,0)$ & $130(82,8)$ & $149(81,9)$ \\
\hline Não & $44(19,2)$ & $5(23,8)$ & $9(18,0)$ & $27(17,2)$ & $33(18,1)$ \\
\hline
\end{tabular}

Nota: Perda de observação: ${ }^{1}$ Motivo da consulta: perda de $1 \quad(n=301) ;{ }^{2}$ Escolaridade: perda de 15 ( $n=287) ;{ }^{3}$ Vida sexual: perda de $1(n=301) ;{ }^{4}$ Libido: perda de $3(n=$ 299); ${ }^{5}$ Parceiros na vida: perda de $1(n=301)$, ${ }^{6}$ Parceiros últimos três meses: perda de 3 ( $n=299)$; ${ }^{7}$ Uso de condom: perda de $9(n=293) ;{ }^{8}$ Contraceptivo hormonal: perda de $5(n=297)$; ${ }^{9}$ Dispaurenia: perda de 10 e excluídas mulheres com vida sexual inativa. $(n=292)$; ${ }^{10}$ Sinusiorragia: perda de 9 e excluídas mulheres com vida sexual inativa ( $n=293) ;{ }^{11}$ Corrimento: perda de $1(n=301) ;{ }^{12}$ Sinais e sintomas: perda de $2(n=300)$.

* $p$ valor: significante $\leq 0,05$. 
5.5.2 Perfil das mulheres que apresentaram Mollicutes nas amostras de swab vaginal

A presença de molicutes nas mulheres foi associada significantemente com as que residem na região rural (Odds Ratio - OR 2,64, IC 95\% 1,24; 5,62, $p=0,010)$, com vida sexual ativa (OR 3,74, IC 95\% 1,64; 8,50, $p=0,001)$ e que relataram um ou mais parceiros sexuais nos últimos três meses (OR 4, 26, IC 95\% 2,09; 8, 69, $\mathrm{p}<0,001)$. Também houve associação negativa com as mulheres que não tinham relação estável (OR 0,49, IC 95\% 0,26; 090, p= 0,020) (Tabela 6). 
Tabela 6 - Detecção de Mollicutes por meio da PCR convencional em amostras de swab vaginal e sua relação com o perfil clínico-demográfico da população de mulheres atendidas em unidades de saúde de Vitória da Conquista - BA, 2011.

(continua)

\begin{tabular}{|c|c|c|c|c|c|}
\hline \multirow{3}{*}{ Variáveis } & Mollicutes Positiva & Mollicutes Negativa & \multirow{3}{*}{$\begin{array}{l}\text { Odds } \\
\text { Ratio } \\
\text { (bruta) }\end{array}$} & \multirow{3}{*}{ IC 95\% } & \multirow{3}{*}{$\mathbf{P}^{*}$} \\
\hline & $\mathrm{N}=\mathbf{2 3 0}$ & $\mathrm{N}=72$ & & & \\
\hline & n (\%) & n (\%) & & & \\
\hline \multicolumn{6}{|l|}{ Dados Demográficos } \\
\hline \multicolumn{6}{|l|}{ Região } \\
\hline Rural & $63(27,4)$ & $9(12,5$ & 2,64 & {$[1,24 ; 5,62]$} & 0,010 \\
\hline Urbana & $167(72,6)$ & $63(87,5)$ & 1 & & \\
\hline \multicolumn{6}{|l|}{ Motivo da Consulta ${ }^{1}$} \\
\hline Sintomático & $64(28,3)$ & $22(30,6)$ & 0,89 & {$[0,50 ; 1,60]$} & 0,715 \\
\hline Rotina & $162(71,7)$ & $50(69,4)$ & 1 & & \\
\hline \multicolumn{6}{|l|}{ Idade } \\
\hline$<25$ anos & $42(18,3)$ & $10(13,9)$ & 1,38 & {$[0,65 ; 2,92]$} & 0,391 \\
\hline$\geq 25$ anos & $188(81,7)$ & $62(86,1)$ & 1 & & \\
\hline \multicolumn{6}{|l|}{ Raça/Cor } \\
\hline Preta/Parda/Indígena & $172(74,8)$ & $54(75,0)$ & 0,98 & {$[0,53 ; 1,82]$} & 0,970 \\
\hline Branca/Amarela & $58(25,2)$ & $18(25,0)$ & 1 & & \\
\hline \multicolumn{6}{|l|}{ Escolaridade $^{2}$} \\
\hline < Ensino Médio & $161(73,9)$ & $44(63,8)$ & 1,60 & {$[0,90 ; 2,85]$} & 0,106 \\
\hline 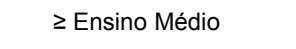 & $57(26,1)$ & $25(36,2)$ & 1 & & \\
\hline \multicolumn{6}{|l|}{ Relação estável } \\
\hline Não & $41(17,8)$ & $22(30,6)$ & 0,49 & {$[0,26 ; 0,90]$} & 0,020 \\
\hline $\operatorname{Sim}$ & $189(82,2)$ & $50(69,4)$ & 1 & & \\
\hline \multicolumn{6}{|l|}{ Saúde Sexual } \\
\hline \multicolumn{6}{|l|}{ Menarca } \\
\hline$<15$ anos & $176(76,5)$ & $62(86,1)$ & 0,52 & {$[0,25 ; 1,09]$} & 0,082 \\
\hline$\geq 15$ anos & $54(23,5)$ & $10(13,9)$ & 1 & & \\
\hline \multicolumn{6}{|l|}{ Primeira relação sexual } \\
\hline$\leq 15$ anos & $54(23,5)$ & $18(25,0)$ & 0,92 & {$[0,49 ; 1,70]$} & 0,791 \\
\hline$>15$ anos & $176(76,5)$ & $54(75,0)$ & 1 & & \\
\hline \multicolumn{6}{|l|}{ Vida Sexual ${ }^{3}$} \\
\hline Ativa & $217(94,3)$ & $58(81,7)$ & 3,74 & {$[1,64 ; 8,50]$} & 0,001 \\
\hline Inativa & $13(5,7)$ & $13(18,3)$ & 1 & & \\
\hline \multicolumn{6}{|l|}{ Libido $^{4}$} \\
\hline Diminuída & $100(43,9)$ & $34(47,9)$ & 0,85 & {$[0,49 ; 1,45]$} & 0,551 \\
\hline Mantida & $128(56,1)$ & $37(52,1)$ & 1 & & \\
\hline \multicolumn{6}{|l|}{ Parceiros na Vida ${ }^{5}$} \\
\hline$\geq 5$ & $21(9,1)$ & $6(8,5)$ & 1,08 & {$[0,42 ; 2,81]$} & 0,86 \\
\hline$<5$ & $209(90,9)$ & $65(91,5)$ & 1 & & \\
\hline \multicolumn{6}{|l|}{ Parceiros últimos 3 meses $^{6}$} \\
\hline$\geq 1$ & $210(92,1)$ & $52(73,2)$ & 4,26 & {$[2,09 ; 8,69]$} & $<0,001$ \\
\hline Nenhum & $18(7,9)$ & $19(26,8)$ & 1 & & \\
\hline \multicolumn{6}{|l|}{ Uso de Condom ${ }^{7}$} \\
\hline Raro/Ocasional & $192(86,1)$ & $59(84,3)$ & 1,15 & {$[0,54 ; 2,43]$} & 0,706 \\
\hline Sempre & $31(13,9)$ & $11(15,7)$ & 1 & & \\
\hline \multicolumn{6}{|l|}{ Contraceptivo Hormonal ${ }^{8}$} \\
\hline $\operatorname{Sim}$ & $86(38,1)$ & $24(33,8)$ & 1,20 & {$[0,68 ; 2,10]$} & 0,518 \\
\hline Não & $140(61,9)$ & $47(66,2)$ & 1 & & \\
\hline
\end{tabular}


Tabela 6 - Detecção de Mollicutes por meio da PCR convencional em amostras de swab vaginal e sua relação com o perfil clínico-demográfico da população de mulheres atendidas em unidades de saúde de Vitória da Conquista - BA, 2011.

(conclusão)

\begin{tabular}{|c|c|c|c|c|c|}
\hline \multirow{3}{*}{ Variáveis } & Mollicutes Positiva & Mollicutes Negativa & \multirow{3}{*}{$\begin{array}{l}\text { Odds } \\
\text { Ratio } \\
\text { (bruta) }\end{array}$} & \multirow{3}{*}{ IC 95\% } & \multirow{3}{*}{$\mathbf{p}^{*}$} \\
\hline & $\mathrm{N}=\mathbf{2 3 0}$ & $N=72$ & & & \\
\hline & n (\%) & n (\%) & & & \\
\hline \multicolumn{6}{|l|}{ Dispareunia $^{9}$} \\
\hline Sim & $75(33,3)$ & $17(25,4)$ & 1,47 & {$[0,79 ; 2,72]$} & 0,218 \\
\hline Não & $150(66,7)$ & $50(74,6)$ & 1 & & \\
\hline \multicolumn{6}{|l|}{ Sinusiorragia ${ }^{10}$} \\
\hline Sim & $20(8,8)$ & $6(9,0)$ & 0,98 & {$[0,37 ; 2,56]$} & 0,979 \\
\hline Não & $206(91,2)$ & $61(91,0)$ & 1 & & \\
\hline \multicolumn{6}{|l|}{ Disúria } \\
\hline Sim & $49(21,3)$ & $15(20,8)$ & 1,02 & {$[0,53 ; 1,97]$} & 0,932 \\
\hline Não & $181(78,7)$ & $57(79,2)$ & 1 & & \\
\hline \multicolumn{6}{|l|}{ Dor Pélvica } \\
\hline Sim & $105(45,7)$ & $30(41,7)$ & 1,17 & {$[0,68 ; 2,00]$} & 0,553 \\
\hline Não & $125(54,3)$ & $42(58,3)$ & 1 & & \\
\hline \multicolumn{6}{|l|}{ Prurido } \\
\hline Sim & $69(30,0)$ & $21(29,2)$ & 1,04 & {$[0,58 ; 1,86]$} & 0,893 \\
\hline Não & $161(70,0)$ & $51(70,8)$ & 1 & & \\
\hline \multicolumn{6}{|l|}{ Corrimento ${ }^{11}$} \\
\hline Sim & $106(46,3)$ & $28(38,9)$ & 1,35 & {$[0,78 ; 2,32]$} & 0,270 \\
\hline Não & $123(53,7)$ & $44(61,1)$ & 1 & & \\
\hline \multicolumn{6}{|l|}{ Sinais e Sintomas ${ }^{12}$} \\
\hline Sim & $185(80,8)$ & $51(71,8)$ & 1,65 & {$[0,89 ; 3,04]$} & 0,108 \\
\hline Não & $44(19,2)$ & $20(28,2)$ & 1 & & \\
\hline
\end{tabular}

Nota: Perda de observação: ${ }^{1}$ Motivo da consulta: perda de 1 ( $\left.n=301\right) ;{ }^{2}$ Escolaridade: perda de $15(n=287) ;{ }^{3}$ Vida sexual: perda de $1(n=301) ;{ }^{4}$ Libido: perda de $3(n=$ 299); ${ }^{5}$ Parceiros na vida: perda de $1(n=301),{ }^{6}$ Parceiros últimos três meses: perda de 3 ( $n=299)$; ${ }^{7}$ Uso de condom: perda de $9(n=293) ;{ }^{8}$ Contraceptivo hormonal: perda de $5(n=297)$; ${ }^{9}$ Dispaurenia: perda de 10 e excluídas mulheres com vida sexual inativa. ( $n=292)$; ${ }^{10}$ Sinusiorragia: perda de 9 e excluídas mulheres com vida sexual inativa ( $n=293) ;{ }^{11}$ Corrimento: perda de $1(n=301) ;{ }^{12}$ Sinais e sintomas: perda de $2(n=300)$.

${ }^{*} \mathrm{p}$ valor: significante $\leq 0,05$. 


\subsubsection{Perfil das mulheres que apresentaram U. urealyticum na PCR convencional}

A detecção de $U$. urealyticum por meio da PCR convencional apresentou associação estatisticamente significante com as mulheres que residiam na região rural do município (OR 2,59, IC 95\% 1,04; 6,43, p = 0,034) (Tabela 7).

\subsubsection{Perfil das mulheres que apresentaram $U$. urealyticum na qPCR}

Ao ser analisado o perfil das mulheres para a presença de $U$. urealyticum, pela técnica de GPCR, foi encontrada associação positiva entre a presença do microrganismo nas mulheres que residiam na região rural (OR 2,85, IC 95\% 1,50; $5,41, p=0,001)$ e entre as mulheres que relataram ter um ou mais parceiros no últimos três meses (OR 8,07, IC 95\% 1,08; 60,35, p =0,016). As variáveis clínicas de sinais e sintomas não apresentaram significância estatística, mas não se pode ignorar a significância clínica desses dados (Tabela 8). 
Tabela 7 - Detecção de $U$. urealyticum por meio da PCR convencional, em amostras de swab vaginal, e sua relação com o perfil das mulheres atendidas em unidades de saúde de Vitória da Conquista - BA, 2011.

(Continua)

\begin{tabular}{|c|c|c|c|c|c|}
\hline Variáveis & $\begin{array}{c}\begin{array}{c}\text { U. urealyticum } \\
\text { PCR-Positivo }\end{array} \\
\mathbf{N}=\mathbf{2 1} \\
\mathbf{N}(\%)\end{array}$ & $\begin{array}{c}\begin{array}{l}\text { U. urealyticum } \\
\text { PCR-Negativo }\end{array} \\
\mathbf{N}=\mathbf{2 8 1} \\
\mathbf{n}(\%)\end{array}$ & $\begin{array}{l}\text { Odds } \\
\text { Ratio } \\
\text { (bruta) }\end{array}$ & IC 95\% & $\mathbf{p}^{*}$ \\
\hline \multicolumn{6}{|l|}{ Dados Demográficos } \\
\hline \multicolumn{6}{|l|}{ Região } \\
\hline Rural & $9(42,9)$ & $63(22,4)$ & 2,59 & {$[1,04 ; 6,43]$} & 0,034 \\
\hline Urbana & $12(57,1)$ & $218(77,6)$ & 1 & & \\
\hline \multicolumn{6}{|l|}{ Motivo da Consulta ${ }^{1}$} \\
\hline Sintomático & $7(35,0)$ & $79(28,4)$ & 1,35 & {$[0,52 ; 3,52]$} & 0,53 \\
\hline Rotina & $13(65,0)$ & $199(71,6)$ & 1 & & \\
\hline \multicolumn{6}{|l|}{ Idade } \\
\hline$<25$ anos & $6(28,6)$ & $46(16,4)$ & 2,04 & {$[0,75 ; 5,54]$} & 0,153 \\
\hline$\geq 25$ anos & $15(71,4)$ & $235(83,6)$ & 1 & & \\
\hline \multicolumn{6}{|l|}{ Raça/Cor } \\
\hline Preta/Parda/Indígena & $18(85,7)$ & $208(74,0)$ & 2,10 & {$[0,60 ; 7,35]$} & 0,234 \\
\hline Branca/Amarela & $3(14,3)$ & $73(26,0)$ & 1 & & \\
\hline \multicolumn{6}{|l|}{ Escolaridade $^{2}$} \\
\hline < Ensino Médio & $13(68,4)$ & $192(71,6)$ & 0,85 & {$[0,31 ; 2,33]$} & 0,764 \\
\hline 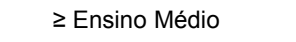 & $6(31,6)$ & $76(28,4)$ & 1 & & \\
\hline \multicolumn{6}{|l|}{ Relação estável } \\
\hline Não & $2(9,5)$ & $61(21,7)$ & 0,38 & {$[0,08 ; 1,67]$} & 0,185 \\
\hline Sim & $19(90,5)$ & $220(78,3)$ & 1 & & \\
\hline \multicolumn{6}{|l|}{ Menarca } \\
\hline$<15$ anos & $17(81,0)$ & $221(78,6)$ & 1,15 & {$[0,37 ; 3,55]$} & 1,154 \\
\hline$\geq 15$ anos & $4(19,0)$ & $60(21,4)$ & 1 & & \\
\hline \multicolumn{6}{|l|}{ Saúde Sexual } \\
\hline \multicolumn{6}{|l|}{ Primeira relação sexual } \\
\hline$\leq 15$ anos & $7(33,3)$ & $65(23,1)$ & 1,66 & {$[0,64 ; 4,29]$} & 0,290 \\
\hline$>15$ anos & $14(66,7)$ & $216(76,9)$ & 1 & & \\
\hline \multicolumn{6}{|l|}{ Vida Sexual ${ }^{3}$} \\
\hline Ativa & $21(100)$ & $254(90,7)$ & & & \\
\hline Inativa & 0 & $26(9,3)$ & 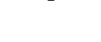 & & \\
\hline \multicolumn{6}{|l|}{ Libido $^{4}$} \\
\hline Diminuída & $9(42,9)$ & $125(45,0)$ & 0,91 & {$[0,37 ; 2,24]$} & 0,852 \\
\hline Mantida & $12(57,1)$ & $153(55,0)$ & 1 & & \\
\hline \multicolumn{6}{|l|}{ Parceiros na Vida ${ }^{5}$} \\
\hline$\geq 5$ & $4(19,0)$ & $23(8,2)$ & 2,62 & {$[0,81 ; 8,46]$} & 0,094 \\
\hline$<5$ & $17(81,0)$ & $257(91,8)$ & 1 & & \\
\hline \multicolumn{6}{|l|}{ Parceiros últimos 3 meses $^{6}$} \\
\hline$\geq 1$ & $21(100)$ & $241(86,7)$ & - & - & - \\
\hline Nenhum & 0 & $37(13,3)$ & 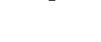 & 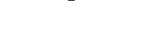 & 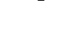 \\
\hline \multicolumn{6}{|l|}{ Uso de Condom ${ }^{7}$} \\
\hline Raro/Ocasional & $18(85,7)$ & $216(79,4)$ & 1,55 & {$[0,44 ; 5,46]$} & 0,488 \\
\hline Sempre & $3(14,3)$ & $56(20,6)$ & 1 & & \\
\hline \multicolumn{6}{|l|}{ Contracepção Hormonal ${ }^{8}$} \\
\hline Sim & $11(52,4)$ & $176(63,8)$ & 0,62 & {$[0,25 ; 1,52]$} & 0,298 \\
\hline Não & $10(47,6)$ & $100(36,2)$ & 1 & & \\
\hline
\end{tabular}


Tabela 7 - Detecção de U. urealyticum por meio da PCR convencional, em amostras de swab vaginal, e sua relação com o perfil das mulheres atendidas em unidades de saúde de Vitória da Conquista - BA, 2011.

(Conclusão)

\begin{tabular}{|c|c|c|c|c|c|}
\hline \multirow{4}{*}{ Variáveis } & U. urealyticum & U. urealyticum & \multirow{4}{*}{$\begin{array}{l}\text { Odds } \\
\text { Ratio } \\
\text { (bruta) }\end{array}$} & \multirow{4}{*}{ IC $95 \%$} & \multirow{4}{*}{$\mathbf{p}^{*}$} \\
\hline & PCR-Positivo & PCR-Negativo & & & \\
\hline & $\mathrm{N}=\mathbf{2 1}$ & $\mathrm{N}=\mathbf{2 8 1}$ & & & \\
\hline & n (\%) & $n(\%)$ & & & \\
\hline \multicolumn{6}{|l|}{ Dispareunia $^{9}$} \\
\hline Sim & $6(28,6)$ & $86(31,7)$ & 0,86 & {$[0,32 ; 2,29]$} & 0,764 \\
\hline Não & $15(71,4)$ & $185(68,3)$ & 1 & & \\
\hline \multicolumn{6}{|l|}{ Sinusiorragia ${ }^{10}$} \\
\hline $\operatorname{Sim}$ & $1(4,8)$ & $25(9,2)$ & 0,49 & {$[0,06 ; 3,83]$} & 0,492 \\
\hline Não & $20(95,2)$ & $247(90,8)$ & 1 & & \\
\hline \multicolumn{6}{|l|}{ Disúria } \\
\hline Sim & $4(19,0)$ & $60(21,4)$ & 0,86 & {$[0,28 ; 2,67]$} & 0,803 \\
\hline Não & $17(81,0)$ & $221(78,6)$ & 1 & & \\
\hline \multicolumn{6}{|l|}{ Dor Pélvica } \\
\hline Sim & $12(57,1)$ & $123(43,8)$ & 1,71 & {$[0,69 ; 4,19]$} & 0,235 \\
\hline Não & $9(42,9)$ & $158(56,2)$ & 1 & & \\
\hline \multicolumn{6}{|l|}{ Prurido } \\
\hline Sim & $8(38,1)$ & $82(29,2)$ & 1,49 & {$[0,59 ; 3,73]$} & 0,389 \\
\hline Não & $13(61,9)$ & $199(70,8)$ & 1 & & \\
\hline \multicolumn{6}{|l|}{ Corrimento ${ }^{11}$} \\
\hline Sim & $9(42,9)$ & $125(44,6)$ & 0,93 & {$[0,38 ; 2,27]$} & 0,874 \\
\hline Não & $12(57,1)$ & $155(55,4)$ & 1 & & \\
\hline \multicolumn{6}{|l|}{ Sinais e Sintomas ${ }^{12}$} \\
\hline Sim & $16(76,2)$ & $220(78,9)$ & 0,85 & {$[0,30 ; 2,43]$} & 0,774 \\
\hline Não & $5(23,8)$ & $59(21,1)$ & 1 & & \\
\hline
\end{tabular}

Nota: Perda de observação: ${ }^{1}$ Motivo da consulta: perda de $1(n=301) ;{ }^{2}$ Escolaridade: perda de $15(n=287)$; ${ }^{3}$ Vida sexual: perda de $1(n=301)$; ${ }^{4}$ Libido: perda de $3(n=$ 299); ${ }^{5}$ Parceiros na vida: perda de $1(n=301)$, ${ }^{6}$ Parceiros últimos três meses: perda de 3 ( $n=299)$; ${ }^{7}$ Uso de condom: perda de 9 ( $\left.n=293\right)$; ${ }^{8}$ Contraceptivo hormonal: perda de $5(n=297)$; ${ }^{9}$ Dispaurenia: perda de 10 e excluídas mulheres com vida sexual inativa. ( $n=292) ;{ }^{10}$ Sinusiorragia: perda de 9 e excluídas mulheres com vida sexual inativa ( $n=293) ;{ }^{11}$ Corrimento: perda de $1(n=301) ;{ }^{12}$ Sinais e sintomas: perda de $2(n=300)$.

${ }^{*} p$ valor: significante $\leq 0,05$. 
Tabela 8 - Detecção de U. urealyticum por meio da qPCR, em amostras de swab vaginal, e sua relação com o perfil das mulheres atendidas em unidades de saúde de Vitória da Conquista-BA, 2011.

(Continua)

\begin{tabular}{|c|c|c|c|c|c|}
\hline \multirow{3}{*}{ Variáveis } & $\begin{array}{l}\text { U. urealyticum } \\
\text { qPCR-Positivo }\end{array}$ & $\begin{array}{l}\text { U. urealyticum } \\
\text { qPCR-Negativo }\end{array}$ & \multirow{3}{*}{$\begin{array}{l}\text { Odds } \\
\text { Ratio } \\
\text { (bruta) }\end{array}$} & \multirow{3}{*}{ IC 95\% } & \multirow{3}{*}{$\mathbf{p}^{*}$} \\
\hline & $\mathrm{N}=\mathbf{5 0}$ & $N=252$ & & & \\
\hline & N (\%) & $\mathrm{n}(\%)$ & & & \\
\hline \multicolumn{6}{|l|}{ Dados Demográficos } \\
\hline \multicolumn{6}{|l|}{ Região } \\
\hline Rural & $21(42,0)$ & $51(20,2)$ & 2,85 & {$[1,50 ; 5,41]$} & 0,001 \\
\hline Urbana & $29(58,0)$ & $201(79,8)$ & 1 & & \\
\hline \multicolumn{6}{|l|}{ Motivo da Consulta ${ }^{1}$} \\
\hline Sintomático & $17(34,7)$ & $69(27,7)$ & 1,39 & {$[0,72 ; 2,66]$} & 0,324 \\
\hline Rotina & $32(65,3)$ & $180(72,3)$ & 1 & & \\
\hline \multicolumn{6}{|l|}{ Idade } \\
\hline$<25$ anos & $11(22,0)$ & $41(16,3)$ & 1,45 & {$[0,68 ; 3,07]$} & 0,327 \\
\hline$\geq 25$ anos & $39(78,0)$ & $211(83,7)$ & 1 & & \\
\hline \multicolumn{6}{|l|}{ Raça/Cor } \\
\hline Preta/Parda/Indígena & $41(82,0)$ & $185(73,4)$ & 1,65 & {$[0,76 ; 3,58]$} & 0,201 \\
\hline Branca/Amarela & $9(18,0)$ & $67(26,6)$ & 1 & & \\
\hline \multicolumn{6}{|l|}{ Escolaridade $^{2}$} \\
\hline < Ensino Médio & $38(79,2)$ & $167(69,9)$ & 1,64 & {$[0,77 ; 3,47]$} & 0,193 \\
\hline 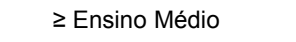 & $10(20,8)$ & $72(30,1)$ & 1 & & \\
\hline \multicolumn{6}{|l|}{ Relação estável } \\
\hline Não & $6(12,0)$ & $57(22,6)$ & 0,47 & {$[0,19 ; 1,15]$} & 0,091 \\
\hline Sim & $44(88,0)$ & $195(77,4)$ & 1 & & \\
\hline \multicolumn{6}{|l|}{ Menarca } \\
\hline$<15$ anos & $41(82,0)$ & $197(78,2)$ & 1,27 & {$[0,58 ; 2,78]$} & 0,545 \\
\hline$\geq 15$ anos & $9(18,0)$ & $55(21,8)$ & 1 & & \\
\hline \multicolumn{6}{|l|}{ Saúde Sexual } \\
\hline \multicolumn{6}{|l|}{ Primeira relação sexual } \\
\hline$\leq 15$ anos & $15(30,0)$ & $57(22,6)$ & 1,47 & {$[0,75 ; 2,87]$} & 0,263 \\
\hline$>15$ anos & $35(70,0)$ & $195(77,4)$ & 1 & & \\
\hline \multicolumn{6}{|l|}{ Vida Sexual ${ }^{3}$} \\
\hline Ativa & $49(98,0)$ & $226(90,0)$ & 5,42 & {$[0,72 ; 40,96]$} & 0,067 \\
\hline Inativa & $1(2,0)$ & $25(10,0)$ & 1 & & \\
\hline \multicolumn{6}{|l|}{ Libido $^{4}$} \\
\hline Diminuída & $19(38,0)$ & $115(46,2)$ & 0,71 & {$[0,38 ; 1,33]$} & 0,288 \\
\hline Mantida & $31(62,0)$ & $134(53,8)$ & 1 & & \\
\hline \multicolumn{6}{|l|}{ Parceiros na Vida ${ }^{5}$} \\
\hline$\geq 5$ & $7(14,0)$ & $20(8,0)$ & 1,88 & {$[0,75 ; 4,72]$} & 0,173 \\
\hline$<5$ & $43(86,0)$ & $231(92,0)$ & 1 & & \\
\hline \multicolumn{6}{|l|}{ Parceiros últimos 3 meses $^{6}$} \\
\hline$\geq 1$ & $48(98,0)$ & $214(85,6)$ & 8,07 & {$[1,08 ; 60,35]$} & 0,016 \\
\hline Nenhum & $1(2,0)$ & $36(14,4)$ & 1 & & \\
\hline \multicolumn{6}{|l|}{ Uso de Condom ${ }^{7}$} \\
\hline Raro/Ocasional & $36(72,0)$ & $198(81,5)$ & 0,58 & {$[0,29 ; 1,17]$} & 0,128 \\
\hline Sempre & $14(28,0)$ & $45(18,5)$ & 1 & & \\
\hline \multicolumn{6}{|l|}{ Contracepção Hormonal ${ }^{8}$} \\
\hline Sim & $30(60,0)$ & $157(63,6)$ & 0,86 & {$[0,486 ; 1,60]$} & 0,634 \\
\hline Não & $20(40,0)$ & $90(36,4)$ & 1 & & \\
\hline
\end{tabular}


Tabela 8 - Detecção de $U$. urealyticum por meio da qPCR, em amostras de swab vaginal, e sua relação com o perfil das mulheres atendidas em unidades de saúde de Vitória da Conquista - BA, 2011.

(Conclusão)

\begin{tabular}{|c|c|c|c|c|c|}
\hline \multirow{4}{*}{ Variáveis } & U. urealyticum & U. urealyticum & \multirow{4}{*}{$\begin{array}{l}\text { Odds } \\
\text { Ratio } \\
\text { (bruta) }\end{array}$} & \multirow{4}{*}{ IC $95 \%$} & \multirow{4}{*}{$\mathbf{p}^{*}$} \\
\hline & qPCR-Positivo & qPCR-Negativo & & & \\
\hline & $\mathrm{N}=\mathbf{5 0}$ & $\mathrm{N}=\mathbf{2 5 2}$ & & & \\
\hline & $n(\%)$ & $n(\%)$ & & & \\
\hline \multicolumn{6}{|l|}{ Dispareunia $^{9}$} \\
\hline Sim & $18(36,0)$ & $74(30,6)$ & 1,28 & {$[0,67 ; 2,42]$} & 0,452 \\
\hline Não & $32(64,0)$ & $168(69,4)$ & 1 & & \\
\hline \multicolumn{6}{|l|}{ Sinusiorragia ${ }^{10}$} \\
\hline Sim & $5(10,0)$ & $21(8,6)$ & 1,17 & {$[0,42 ; 3,28]$} & 0,758 \\
\hline Não & $45(90,0)$ & $222(91,4)$ & 1 & & \\
\hline \multicolumn{6}{|l|}{ Disúria } \\
\hline Sim & $11(22,0)$ & $53(21,0)$ & 1,06 & {$[0,51 ; 2,21]$} & 0,878 \\
\hline Não & $39(78,0)$ & $199(79,0)$ & 1 & & \\
\hline \multicolumn{6}{|l|}{ Dor Pélvica } \\
\hline Sim & $24(48,0)$ & $111(44,0)$ & 1,17 & {$[0,64 ; 2,15]$} & 0,608 \\
\hline Não & $26(52,0)$ & $141(56,0)$ & 1 & & \\
\hline \multicolumn{6}{|l|}{ Prurido } \\
\hline $\operatorname{Sim}$ & $18(36,0)$ & $72(28,6)$ & 1,41 & {$[0,74 ; 2,66]$} & 0,294 \\
\hline Não & $32(64,0)$ & $180(71,4)$ & 1 & & \\
\hline \multicolumn{6}{|l|}{ Corrimento ${ }^{11}$} \\
\hline Sim & $24(48,0)$ & $110(43,8)$ & 1,18 & {$[0,64 ; 2,17]$} & 0,587 \\
\hline Não & $26(52,0)$ & $141(56,2)$ & 1 & & \\
\hline \multicolumn{6}{|l|}{ Sinais e Sintomas ${ }^{12}$} \\
\hline Sim & $41(82,0)$ & $195(78,0)$ & 1,28 & {$[0,58 ; 2,81]$} & 0,529 \\
\hline Não & $9(18,0)$ & $55(22,0)$ & 1 & & \\
\hline
\end{tabular}

Nota: Perda de observação: ${ }^{1}$ Motivo da consulta: perda de $1(n=301) ;{ }^{2}$ Escolaridade: perda de 15 ( $n=287)$; ${ }^{3}$ Vida sexual: perda de 1 ( $\left.n=301\right)$; ${ }^{4}$ Libido: perda de $3(n=299)$; ${ }^{5}$ Parceiros na vida: perda de $1(n=301)$, ${ }^{6}$ Parceiros últimos três meses: perda de 3 $(n=299) ;{ }^{7}$ Uso de condom: perda de $9(n=293) ;{ }^{8}$ Contraceptivo hormonal: perda de 5 $(n=297)$; ${ }^{9}$ Dispaurenia: perda de 10 e excluídas mulheres com vida sexual inativa. $(n=292) ;{ }^{10}$ Sinusiorragia: perda de 9 e excluídas mulheres com vida sexual inativa $(n=293) ;{ }^{11}$ Corrimento: perda de $1(n=301) ;{ }^{12}$ Sinais e sintomas: perda de $2(n=300)$.

${ }^{*} p$ valor: significante $\leq 0,05$. 


\subsubsection{Perfil das mulheres que apresentaram U. parvum na PCR convencional}

As mulheres positivas para U. parvum também apresentaram associação positiva com variáveis relacionadas à saúde sexual, entre elas, ter vida sexual ativa (OR 2,66, IC 95\% 1,12; 6,32, $\mathrm{p}=0,022$ ) e um ou mais parceiros no últimos três meses (OR 2,88, IC 95\% 1,37; 6,08, $p=0,004$ ) (Tabela 9). Também houve associação clínica com os sinais e sintomas de infecção, porém sem significância estatística.

5.5.6 Perfil das mulheres que apresentaram os sorotipos de U. parvum na PCR convencional

O perfil das mulheres também foi comparado com os diferentes sorotipos de U. parvum, e houve associação do Sorotipo $1 \mathrm{com}$ as mulheres que residem na região rural (OR 4,22, IC 95\% 2,07; 8,60, p < 0,001) e o sintoma disúria (OR 2,27; IC $95 \% 1,08 ; 4,77, p=0,027$ ) (Tabela 10). Os Sorotipos 3 e 14 foram associados com um ou mais parceiros nos últimos três meses (OR 5,19, IC 95\% 1,21; 22,2, p = 0,014 ) e a presença de corrimento vaginal (OR 1,92, IC 95\% 1,09; 3,39, p = 0,024) (Tabela 11). Não houve associação significante com a presença do Sorotipo 6 e os fatores demográficos e de saúde sexual das mulheres (Tabela 12). 
Tabela 9 - Detecção de U. parvum por meio da PCR convencional em amostras de swab vaginal, e sua relação com o perfil das mulheres atendidas em unidades de saúde de Vitória da Conquista - BA, 2011.

(Continua)

\begin{tabular}{|c|c|c|c|c|c|}
\hline Variáveis & $\begin{array}{c}\begin{array}{c}\text { U. parvum } \\
\text { PCR-Positivo }\end{array} \\
\mathrm{N}=157 \\
\mathrm{~N}(\%)\end{array}$ & $\begin{array}{c}\begin{array}{c}\text { U. parvum } \\
\text { PCR-Negativo }\end{array} \\
\mathrm{N}=\mathbf{1 4 5} \\
\mathrm{n}(\%)\end{array}$ & $\begin{array}{l}\text { Odds } \\
\text { Ratio } \\
\text { (bruta) }\end{array}$ & IC $95 \%$ & $\mathbf{P}^{*}$ \\
\hline \multicolumn{6}{|l|}{ Dados Demográficos } \\
\hline \multicolumn{6}{|l|}{ Região } \\
\hline Rural & $41(26,1)$ & $31(21,4)$ & 1,30 & {$[0,76 ; 2,22]$} & 0,335 \\
\hline Urbana & $116(73,9)$ & $114(78,6)$ & 1 & & \\
\hline \multicolumn{6}{|l|}{ Motivo da Consulta ${ }^{1}$} \\
\hline Sintomático & $45(29,2)$ & $41(28,5)$ & 1,04 & {$[0,63 ; 1,71]$} & 0,887 \\
\hline Rotina & $109(70,8)$ & $103(71,5)$ & 1 & & \\
\hline \multicolumn{6}{|l|}{ Idade } \\
\hline$<25$ anos & $30(19,1)$ & $22(15,2)$ & 1,32 & {$[0,72 ; 2,41]$} & 0,365 \\
\hline$\geq 25$ anos & $127(80,9)$ & $123(84,8)$ & 1 & & \\
\hline \multicolumn{6}{|l|}{ Raça/Cor } \\
\hline Preta/Parda/Indígena & $123(78,3)$ & $103(71,0)$ & 1,47 & {$[0,87 ; 2,49]$} & 0,144 \\
\hline Branca/Amarela & $34(21,7)$ & $42(29,0)$ & 1 & & \\
\hline \multicolumn{6}{|l|}{ Escolaridade $^{2}$} \\
\hline < Ensino Médio & $105(70,9)$ & $100(71,9)$ & 0,95 & {$[0,57 ; 1,59]$} & 0,852 \\
\hline$\geq$ Ensino Médio & $43(29,1)$ & $39(28,1)$ & 1 & & \\
\hline \multicolumn{6}{|l|}{ Relação estável } \\
\hline Não & $32(20,4)$ & $31(21,4)$ & 0,94 & {$[0,54 ; 1,64]$} & 0,831 \\
\hline Sim & $125(79,6)$ & $114(78,6)$ & 1 & & \\
\hline \multicolumn{6}{|l|}{ Menarca } \\
\hline$<15$ anos & $121(77,1)$ & $117(80,7)$ & 0,80 & {$[0,46 ; 1,40]$} & 0,442 \\
\hline$\geq 15$ anos & $36(22,9)$ & $28(19,3)$ & 1 & & \\
\hline \multicolumn{6}{|l|}{ Saúde Sexual } \\
\hline \multicolumn{6}{|l|}{ Primeira relação sexual } \\
\hline$\leq 15$ anos & $34(21,7)$ & $38(26,2)$ & 0,78 & {$[0,46 ; 1,32]$} & 0,354 \\
\hline$>15$ anos & $123(78,3)$ & $107(73,8)$ & 1 & & \\
\hline \multicolumn{6}{|l|}{ Vida Sexual ${ }^{3}$} \\
\hline Ativa & $149(94,9)$ & $126(87,5)$ & 2,66 & {$[1,12 ; 6,32]$} & 0,022 \\
\hline Inativa & $8(5,1)$ & $18(12,5)$ & 1 & & \\
\hline \multicolumn{6}{|l|}{ Libido $^{4}$} \\
\hline Diminuída & $67(43,2)$ & $67(46,5)$ & 0,87 & {$[0,55 ; 1,38]$} & 0,57 \\
\hline Mantida & $88(56,8)$ & $77(53,5)$ & 1 & & \\
\hline \multicolumn{6}{|l|}{ Parceiros na Vida ${ }^{5}$} \\
\hline$\geq 5$ & $18(11,5)$ & $9(6,2)$ & 1,94 & {$[0,84 ; 4,47]$} & 0,114 \\
\hline$<5$ & $139(88,5)$ & $135(93,8)$ & 1 & & \\
\hline \multicolumn{6}{|l|}{ Parceiros últimos 3 meses $^{6}$} \\
\hline$\geq 1$ & $144(92,9)$ & $118(81,9)$ & 2,88 & {$[1,37 ; 6,08]$} & 0,004 \\
\hline Nenhum & $11(7,1)$ & $26(18,1)$ & 1 & & \\
\hline \multicolumn{6}{|l|}{ Uso de Condom ${ }^{7}$} \\
\hline Raro/Ocasional & $118(77,6)$ & $116(82,3)$ & 0,75 & {$[0,42 ; 1,33]$} & 0,323 \\
\hline Sempre & $34(22,4)$ & $25(17,7)$ & 1 & & \\
\hline \multicolumn{6}{|l|}{ Contraceptivo Hormonal ${ }^{8}$} \\
\hline $\operatorname{Sim}$ & $98(63,6)$ & $89(62,2)$ & 1,06 & {$[0,66 ; 1,70]$} & 0,803 \\
\hline Não & $56(36,4)$ & $54(37,8)$ & 1 & & \\
\hline
\end{tabular}


Tabela 9 - Detecção de U. parvum por meio da PCR convencional em amostras de swab vaginal, e sua relação com o perfil das mulheres atendidas em unidades de saúde de Vitória da Conquista - BA, 2011.

(Conclusão)

\begin{tabular}{|c|c|c|c|c|c|}
\hline \multirow{3}{*}{ Variáveis } & $\begin{array}{c}\text { U. parvum } \\
\text { PCR-Positivo }\end{array}$ & $\begin{array}{c}\text { U. parvum } \\
\text { PCR-Negativo }\end{array}$ & \multirow{3}{*}{$\begin{array}{c}\text { Odds } \\
\text { Ratio } \\
\text { (bruta) }\end{array}$} & \multirow{3}{*}{ IC 95\% } & \multirow{3}{*}{$\mathbf{P}^{*}$} \\
\hline & $N=157$ & $N=145$ & & & \\
\hline & $\mathrm{N}(\%)$ & $n(\%)$ & & & \\
\hline \multicolumn{6}{|l|}{ Dispareunia $^{9}$} \\
\hline Sim & $54(35,3)$ & $38(27,3)$ & 1,45 & {$[0,88 ; 2,39]$} & 0,144 \\
\hline Não & $99(64,7)$ & $101(72,7)$ & 1 & & \\
\hline \multicolumn{6}{|l|}{ Sinusiorragia ${ }^{10}$} \\
\hline Sim & $13(8,4)$ & $13(9,4)$ & 0,89 & {$[0,40 ; 2,00]$} & 0,784 \\
\hline Não & $141(91,6)$ & $126(90,6)$ & 1 & & \\
\hline \multicolumn{6}{|l|}{ Disúria } \\
\hline Sim & $38(24,2)$ & $26(17,9)$ & 1,46 & {$[0,84 ; 2,56]$} & 0,183 \\
\hline Não & $119(75,8)$ & $119(82,1)$ & 1 & & \\
\hline \multicolumn{6}{|l|}{ Dor Pélvica } \\
\hline Sim & $76(48,4)$ & $59(40,7)$ & 1,37 & {$[0,87 ; 2,16]$} & 0,178 \\
\hline Não & $81(51,6)$ & $86(59,3)$ & 1 & & \\
\hline \multicolumn{6}{|l|}{ Prurido } \\
\hline Sim & $54(34,4)$ & $36(24,8)$ & 1,59 & {$[0,96 ; 2,62]$} & 0,069 \\
\hline Não & $103(65,6)$ & $109(75,2)$ & 1 & & \\
\hline \multicolumn{6}{|l|}{ Corrimento 11} \\
\hline Sim & $77(49,4)$ & $57(39,3)$ & 1,50 & {$[0,95 ; 2,39]$} & 0,080 \\
\hline Não & $79(50,6)$ & $88(60,7)$ & 1 & & \\
\hline \multicolumn{6}{|c|}{ Sinais e Sintomas ${ }^{12}$} \\
\hline Sim & $130(82,8)$ & $106(74,1)$ & 1,68 & {$[0,96 ; 2,94]$} & 0,067 \\
\hline Não & $27(17,2)$ & $37(25,9)$ & 1 & & \\
\hline
\end{tabular}

Nota: Perda de observação: ${ }^{1}$ Motivo da consulta: perda de $1(n=301) ;{ }^{2}$ Escolaridade: perda de $15(n=287)$; ${ }^{3}$ Vida sexual: perda de $1(n=301)$; ${ }^{4}$ Libido: perda de $3(n=$ 299); ${ }^{5}$ Parceiros na vida: perda de 1 ( $\left.n=301\right),{ }^{6}$ Parceiros últimos três meses: perda de 3 ( $n=299)$; ${ }^{7}$ Uso de condom: perda de 9 ( $\left.n=293\right) ;{ }^{8}$ Contraceptivo hormonal: perda de $5(n=297)$; ${ }^{9}$ Dispaurenia: perda de 10 e excluídas mulheres com vida sexual inativa. ( $n=292)$; ${ }^{10}$ Sinusiorragia: perda de 9 e excluídas mulheres com vida sexual inativa $(n=293) ;{ }^{11}$ Corrimento: perda de $1(n=301) ;{ }^{12}$ Sinais e sintomas: perda de $2(n=300)$.

${ }^{*} \mathrm{p}$ valor: significante $\leq 0,05$. 
Tabela 10 - Detecção de U. parvum Sorotipo 1 por meio da PCR em amostras de swab vaginal, e sua relação com o perfil das mulheres atendidas em unidades de saúde de Vitória da Conquista - BA, 2011.

(Continua)

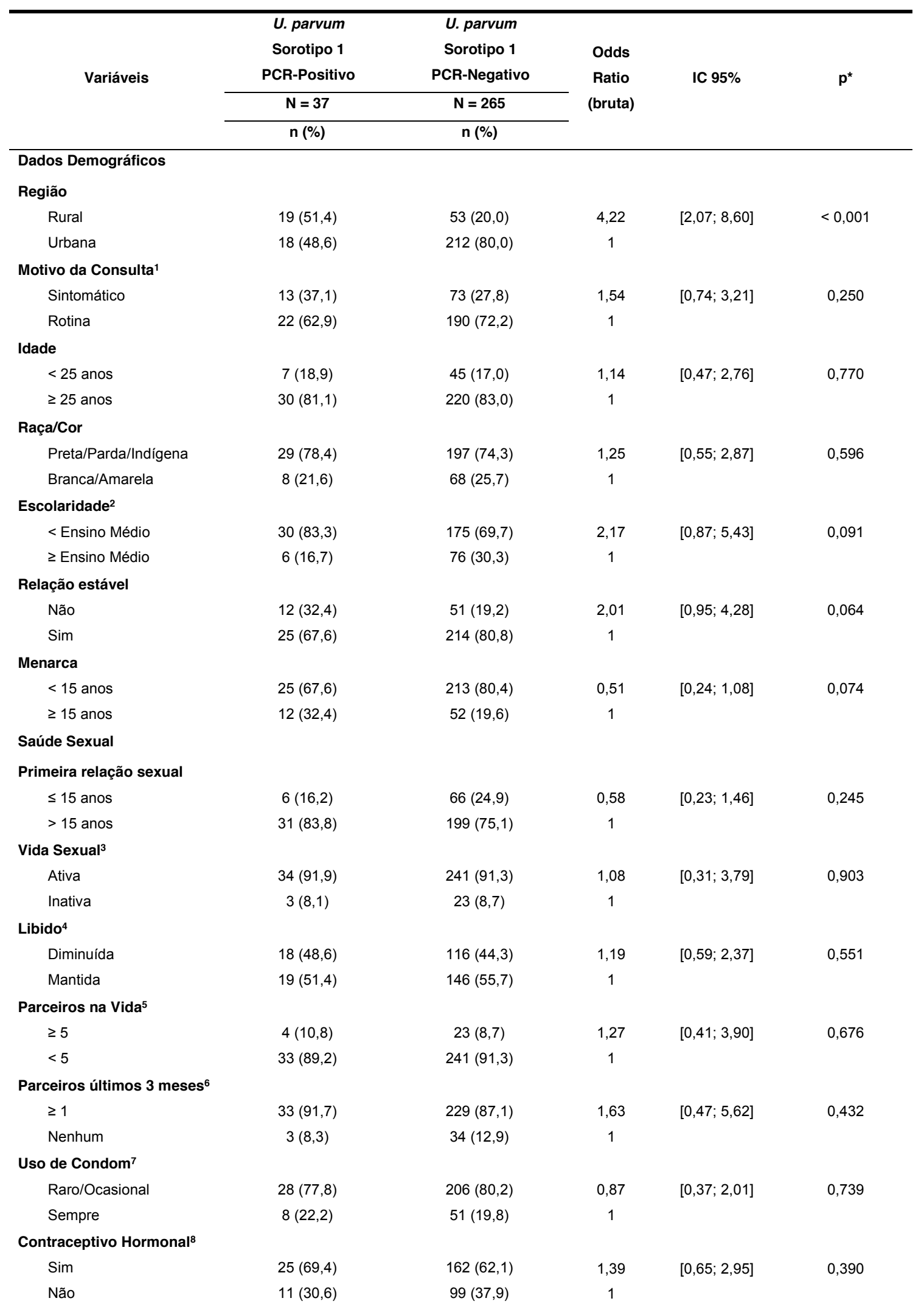


Tabela 10 - Detecção de U. parvum Sorotipo 1 por meio da PCR em amostras de swab vaginal, e sua relação com o perfil das mulheres atendidas em unidades de saúde de Vitória da Conquista - BA, 2011.

(Conclusão)

\begin{tabular}{|c|c|c|c|c|c|}
\hline \multirow{5}{*}{ Variáveis } & U. parvum & U. parvum & \multirow{5}{*}{$\begin{array}{l}\text { Odds } \\
\text { Ratio } \\
\text { (bruta) }\end{array}$} & \multirow{5}{*}{ IC 95\% } & \multirow{5}{*}{$\mathbf{p}^{*}$} \\
\hline & Sorotipo 1 & Sorotipo 1 & & & \\
\hline & PCR-Positivo & PCR-Negativo & & & \\
\hline & $\mathrm{N}=37$ & $N=265$ & & & \\
\hline & n (\%) & n (\%) & & & \\
\hline \multicolumn{6}{|l|}{ Dispareunia $^{9}$} \\
\hline Sim & $13(36,1)$ & $79(30,9)$ & 1,27 & {$[0,61 ; 2,63]$} & 0,525 \\
\hline Não & $23(63,9)$ & $177(69,1)$ & 1 & & \\
\hline \multicolumn{6}{|l|}{ Sinusiorragia ${ }^{10}$} \\
\hline Sim & $1(2,7)$ & $25(9,8)$ & 0,26 & {$[0,03 ; 1,95]$} & 0,158 \\
\hline Não & $36(97,3)$ & $231(90,2)$ & 1 & & \\
\hline \multicolumn{6}{|l|}{ Disúria } \\
\hline Sim & $13(35,1)$ & $51(19,2)$ & 2,27 & {$[1,08 ; 4,77]$} & 0,027 \\
\hline Não & $24(64,9)$ & $214(80,8)$ & 1 & & \\
\hline \multicolumn{6}{|l|}{ Dor Pélvica } \\
\hline Sim & $22(59,5)$ & $113(42,6)$ & 1,97 & {$[0,98 ; 3,97]$} & 0,054 \\
\hline Não & $15(40,5)$ & $152(57,4)$ & 1 & & \\
\hline \multicolumn{6}{|l|}{ Prurido } \\
\hline Sim & $11(29,7)$ & $79(29,8)$ & 0,99 & {$[0,47 ; 2,11]$} & 0,992 \\
\hline Não & $26(70,3)$ & $186(70,2)$ & 1 & & \\
\hline \multicolumn{6}{|l|}{ Corrimento ${ }^{11}$} \\
\hline Sim & $19(51,4)$ & $115(43,6)$ & 1,37 & {$[0,69 ; 2,72]$} & 0,372 \\
\hline Não & $18(48,6)$ & $149(56,4)$ & 1 & & \\
\hline \multicolumn{6}{|l|}{ Sinais e Sintomas ${ }^{12}$} \\
\hline Sim & $31(83,8)$ & $205(77,9)$ & 1,46 & {$[0,58 ; 3,67]$} & 0,417 \\
\hline Não & $6(16,2)$ & $58(22,1)$ & 1 & & \\
\hline
\end{tabular}

Nota: Perda de observação: ${ }^{1}$ Motivo da consulta: perda de $1(n=301) ;{ }^{2}$ Escolaridade: perda de $15(n=287)$; ${ }^{3}$ Vida sexual: perda de $1(n=301) ;{ }^{4}$ Libido: perda de $3(n=$ 299); ${ }^{5}$ Parceiros na vida: perda de 1 ( $\left.n=301\right),{ }^{6}$ Parceiros últimos três meses: perda de $3(n=299) ;{ }^{7}$ Uso de condom: perda de $9(n=293) ;{ }^{8}$ Contraceptivo hormonal: perda de $5(n=297)$; ${ }^{9}$ Dispaurenia: perda de 10 e excluídas mulheres com vida sexual inativa. $(n=292)$; ${ }^{10}$ Sinusiorragia: perda de 9 e excluídas mulheres com vida sexual inativa ( $n=293) ;{ }^{11}$ Corrimento: perda de $1(n=301) ;{ }^{12}$ Sinais e sintomas: perda de $2(n=300)$.

${ }^{*} p$ valor: significante $\leq 0,05$. 
Tabela 11 - Detecção de U. parvum Sorotipo $3 / 14$ por meio da PCR em amostras de swab vaginal, e sua relação com o perfil das mulheres atendidas em unidades de saúde de Vitória da Conquista - BA, 2011.

(Continua)

\begin{tabular}{|c|c|c|c|c|c|}
\hline \multirow[t]{3}{*}{ Variáveis } & $\begin{array}{c}\text { U. parvum } \\
\text { Sorotipo } 3 \text { e } 14 \\
\text { PCR-Positivo }\end{array}$ & $\begin{array}{c}\text { U. parvum } \\
\text { Sorotipo } 3 \text { e } 14 \\
\text { PCR-Negativo }\end{array}$ & \multirow{3}{*}{$\begin{array}{l}\text { Odds } \\
\text { Ratio } \\
\text { (bruta) }\end{array}$} & \multirow[t]{3}{*}{ IC 95\% } & \multirow[t]{3}{*}{$\mathbf{p}^{*}$} \\
\hline & $\mathrm{N}=62$ & $N=240$ & & & \\
\hline & n (\%) & $\mathrm{n}(\%)$ & & & \\
\hline \multicolumn{6}{|l|}{ Dados Demográficos } \\
\hline \multicolumn{6}{|l|}{ Região } \\
\hline Rural & $18(29,0)$ & $54(22,5)$ & 1,41 & {$[0,75 ; 2,64]$} & 0,282 \\
\hline Urbana & $44(71,0)$ & $186(77,5)$ & 1 & & \\
\hline \multicolumn{6}{|l|}{ Motivo da Consulta ${ }^{1}$} \\
\hline Sintomático & $15(24,6)$ & $71(30,0)$ & 0,76 & {$[0,40 ; 1,45]$} & 0,409 \\
\hline Rotina & $46(75,4)$ & $166(70,0)$ & 1 & & \\
\hline \multicolumn{6}{|l|}{ Idade } \\
\hline$<25$ anos & $11(17,7)$ & $41(17,1)$ & 1,04 & {$[0,50 ; 2,18]$} & 0,903 \\
\hline$\geq 25$ anos & $51(82,3)$ & $199(82,9)$ & 1 & & \\
\hline \multicolumn{6}{|l|}{ Raça/Cor } \\
\hline Preta/Parda/Indígena & $49(79,0)$ & $177(73,8)$ & 1,34 & {$[0,68 ; 2,64]$} & 0,480 \\
\hline Branca/Amarela & $13(21,0)$ & $63(26,2)$ & 1 & & \\
\hline \multicolumn{6}{|l|}{ Escolaridade $^{2}$} \\
\hline < Ensino Médio & $44(71,0)$ & $161(71,6)$ & 0,97 & {$[0,52 ; 1,81]$} & 0,928 \\
\hline$\geq$ Ensino Médio & $18(29,0)$ & $64(28,4)$ & 1 & & \\
\hline \multicolumn{6}{|l|}{ Relação estável } \\
\hline Não & $12(19,4)$ & $51(21,2)$ & 0,89 & {$[0,44 ; 1,79]$} & 0,743 \\
\hline Sim & $50(80,6)$ & $189(78,8)$ & 1 & & \\
\hline \multicolumn{6}{|l|}{ Menarca } \\
\hline$<15$ anos & $50(80,6)$ & $188(78,3)$ & 1,15 & {$[0,57 ; 2,32]$} & 0,691 \\
\hline$\geq 15$ anos & $12(19,4)$ & $52(21,7)$ & 1 & & \\
\hline \multicolumn{6}{|l|}{ Saúde Sexual } \\
\hline \multicolumn{6}{|l|}{ Primeira relação sexual } \\
\hline$\leq 15$ anos & $9(14,5)$ & $63(26,2)$ & 0,48 & {$[0,22 ; 1,02]$} & 0,053 \\
\hline$>15$ anos & $53(85,5)$ & $177(73,8)$ & 1 & & \\
\hline \multicolumn{6}{|l|}{ Vida Sexual ${ }^{3}$} \\
\hline Ativa & $61(98,4)$ & $214(89,5)$ & 7,13 & {$[0,95 ; 53,6]$} & 0,128 \\
\hline Inativa & $1(1,6)$ & $25(10,5)$ & 1 & & \\
\hline \multicolumn{6}{|l|}{ Libido $^{4}$} \\
\hline Diminuída & $23(37,7)$ & $111(46,6)$ & 0,69 & {$[0,39 ; 1,23]$} & 0,670 \\
\hline Mantida & $38(62,3)$ & $127(53,4)$ & 1 & & \\
\hline \multicolumn{6}{|l|}{ Parceiros na Vida ${ }^{5}$} \\
\hline$\geq 5$ & $5(8,1)$ & $22(9,2)$ & 0,86 & {$[0,31 ; 2,38]$} & 0,779 \\
\hline$<5$ & $57(91,9)$ & $217(90,8)$ & 1 & & \\
\hline \multicolumn{6}{|l|}{ Parceiros últimos 3 meses $^{6}$} \\
\hline$\geq 1$ & $60(96,8)$ & $202(85,2)$ & 5,19 & {$[1,21 ; 22,2]$} & 0,014 \\
\hline Nenhum & $2(3,2)$ & $35(14,8)$ & 1 & & \\
\hline \multicolumn{6}{|l|}{ Uso de Condom ${ }^{7}$} \\
\hline Raro/Ocasional & $49(80,3)$ & $185(79,7)$ & 1,04 & {$[0,51 ; 2,10]$} & 0,919 \\
\hline Sempre & $12(19,7)$ & $47(20,3)$ & 1 & & \\
\hline \multicolumn{6}{|l|}{ Contraceptivo Hormonal ${ }^{8}$} \\
\hline Sim & $37(59,7)$ & $150(63,8)$ & 0,84 & {$[0,47 ; 1,49]$} & 0,547 \\
\hline Não & $25(40,3)$ & $85(36,2)$ & 1 & & \\
\hline
\end{tabular}


Tabela 11 - Detecção de U. parvum Sorotipo 3/14 por meio da PCR em amostras de swab vaginal, e sua relação com o perfil das mulheres atendidas em unidades de saúde de Vitória da Conquista - BA, 2011.

(Conclusão)

\begin{tabular}{|c|c|c|c|c|c|}
\hline \multirow[t]{3}{*}{ Variáveis } & $\begin{array}{c}\text { U. parvum } \\
\text { Sorotipo } 3 \text { e } 14 \\
\text { PCR-Positivo }\end{array}$ & $\begin{array}{c}\text { U. parvum } \\
\text { Sorotipo } 3 \text { e } 14 \\
\text { PCR-Negativo }\end{array}$ & \multirow{3}{*}{$\begin{array}{l}\text { Odds } \\
\text { Ratio } \\
\text { (bruta) }\end{array}$} & \multirow[t]{3}{*}{ IC $95 \%$} & \multirow[t]{3}{*}{$\mathbf{p}^{\star}$} \\
\hline & $N=62$ & $N=\mathbf{2 4 0}$ & & & \\
\hline & n (\%) & n (\%) & & & \\
\hline \multicolumn{6}{|l|}{ Dispareunia $^{9}$} \\
\hline Sim & $24(40,0)$ & $68(29,3)$ & 1,01 & {$[0,89 ; 2,89]$} & 0,112 \\
\hline Não & $36(60,0)$ & $164(70,7)$ & & & \\
\hline \multicolumn{6}{|l|}{ Sinusiorragia ${ }^{10}$} \\
\hline Sim & $5(8,2)$ & $21(9,1)$ & 0,89 & {$[0,32 ; 2,48]$} & 0,834 \\
\hline Não & $56(91,8)$ & $211(90,9)$ & 1 & & \\
\hline \multicolumn{6}{|l|}{ Disúria } \\
\hline Sim & $11(17,7)$ & $53(22,1)$ & 0,76 & {$[0,37 ; 1,56]$} & 0,456 \\
\hline Não & $51(82,3)$ & $187(77,9)$ & 1 & & \\
\hline \multicolumn{6}{|l|}{ Dor Pélvica } \\
\hline Sim & $28(45,2)$ & $107(44,6)$ & 1,02 & {$[0,58 ; 1,79]$} & 0,935 \\
\hline Não & $34(54,8)$ & $133(55,4)$ & 1 & & \\
\hline \multicolumn{6}{|l|}{ Prurido } \\
\hline Sim & $19(30,6)$ & $71(29,6)$ & 1,05 & {$[0,57 ; 1,93]$} & 0,871 \\
\hline Não & $43(69,4)$ & $169(70,4)$ & 1 & & \\
\hline \multicolumn{6}{|l|}{ Corrimento ${ }^{11}$} \\
\hline Sim & $35(57,4)$ & $99(41,2)$ & 1,92 & {$[1,09 ; 3,39]$} & 0,024 \\
\hline Não & $26(42,6)$ & $141(58,8)$ & 1 & & \\
\hline \multicolumn{6}{|l|}{ Sinais e Sintomas ${ }^{12}$} \\
\hline Sim & $52(83,9)$ & $184(77,3)$ & 1,53 & {$[0,73 ; 3,20]$} & 0,004 \\
\hline Não & $10(16,1)$ & $54(22,7)$ & 1 & & \\
\hline
\end{tabular}

Nota: Perda de observação: ${ }^{1}$ Motivo da consulta: perda de 1 ( $\left.n=301\right)$; ${ }^{2}$ Escolaridade: perda de $15(n=287)$; ${ }^{3}$ Vida sexual: perda de $1(n=301) ;{ }^{4}$ Libido: perda de $3(n=$ 299); ${ }^{5}$ Parceiros na vida: perda de $1(n=301),{ }^{6}$ Parceiros últimos três meses: perda de 3 ( $n=299)$; ${ }^{7}$ Uso de condom: perda de $9(n=293)$; ${ }^{8}$ Contraceptivo hormonal: perda de $5(n=297)$; ${ }^{9}$ Dispaurenia: perda de 10 e excluídas mulheres com vida sexual inativa. ( $n=292) ;{ }^{10}$ Sinusiorragia: perda de 9 e excluídas mulheres com vida sexual inativa ( $n=293) ;{ }^{11}$ Corrimento: perda de $1(n=301) ;{ }^{12}$ Sinais e sintomas: perda de $2(n=300)$.

${ }^{*} p$ valor: significante $\leq 0,05$. 
Tabela 12 - Detecção de U. parvum Sorotipo 6 por meio da PCR em amostras de swab vaginal, e sua relação com o perfil das mulheres atendidas em unidades de saúde de Vitória da Conquista - BA, 2011.

(Continua)

\begin{tabular}{|c|c|c|c|c|c|}
\hline \multirow{5}{*}{ Variáveis } & U. parvum & U. parvum & \multirow{5}{*}{$\begin{array}{l}\text { Odds } \\
\text { Ratio } \\
\text { (bruta) }\end{array}$} & \multirow{5}{*}{ IC 95\% } & \multirow{5}{*}{$\mathbf{p}^{*}$} \\
\hline & Sorotipo 6 & Sorotipo 6 & & & \\
\hline & PCR-Positivo & PCR-Negativo & & & \\
\hline & $N=64$ & $\mathrm{~N}=\mathbf{2 3 8}$ & & & \\
\hline & n (\%) & $\mathbf{N}(\%)$ & & & \\
\hline \multicolumn{6}{|l|}{ Dados Demográficos } \\
\hline \multicolumn{6}{|l|}{ Região } \\
\hline Rural & $16(25,0)$ & $56(23,5)$ & 1,08 & {$[0,57 ; 2,05]$} & 0,806 \\
\hline Urbana & $48(75,0)$ & $182(76,5)$ & 1 & & \\
\hline \multicolumn{6}{|l|}{ Motivo da Consulta ${ }^{1}$} \\
\hline Sintomático & $22(35,5)$ & $64(27,1)$ & 1,48 & {$[0,82 ; 2,68]$} & 0,196 \\
\hline Rotina & $40(64,5)$ & $172(72,9)$ & 1 & & \\
\hline \multicolumn{6}{|l|}{ Idade } \\
\hline$<25$ anos & $11(17,2)$ & $41(17,2)$ & 0,99 & {$[0,48 ; 2,07]$} & 0,994 \\
\hline$\geq 25$ anos & $53(82,8)$ & $197(82,8)$ & 1 & & \\
\hline \multicolumn{6}{|l|}{ Raça/Cor } \\
\hline Preta/Parda/Indígena & $47(73,4)$ & $179(75,2)$ & 0,91 & {$[0,49 ; 1,71]$} & 0,772 \\
\hline Branca/Amarela & $17(26,6)$ & $59(24,8)$ & 1 & & \\
\hline \multicolumn{6}{|l|}{ Escolaridade $^{2}$} \\
\hline$<$ Ensino Médio & $41(68,3)$ & $164(72,2)$ & 0,83 & {$[0,45 ; 1,54]$} & 0,551 \\
\hline$\geq$ Ensino Médio & $19(31,7)$ & $63(27,8)$ & 1 & & \\
\hline \multicolumn{6}{|l|}{ Relação estável } \\
\hline Não & $9(14,1)$ & $54(22,7)$ & 0,56 & {$[0,26 ; 1,20]$} & 0,132 \\
\hline Sim & $55(85,9)$ & $184(77,3)$ & 1 & & \\
\hline \multicolumn{6}{|l|}{ Menarca } \\
\hline$<15$ anos & $50(78,1)$ & $188(79,0)$ & 0,95 & {$[0,49 ; 1,86]$} & 0,880 \\
\hline$\geq 15$ anos & $14(21,9)$ & $50(21,0)$ & 1 & & \\
\hline \multicolumn{6}{|l|}{ Saúde Sexual } \\
\hline \multicolumn{6}{|l|}{ Primeira relação sexual } \\
\hline$\leq 15$ anos & $13(20,3)$ & $59(24,8)$ & 0,77 & {$[0,39 ; 1,52]$} & 0,456 \\
\hline$>15$ anos & $51(79,7)$ & $179(75,2)$ & 1 & & \\
\hline \multicolumn{6}{|l|}{ Vida Sexual ${ }^{3}$} \\
\hline Ativa & $61(95,3)$ & $214(90,3)$ & 2,18 & {$[0,63 ; 7,52]$} & 0,205 \\
\hline Inativa & $3(4,7)$ & $23(9,7)$ & 1 & & \\
\hline \multicolumn{6}{|l|}{ Libido $^{4}$} \\
\hline Diminuída & $29(45,3)$ & $105(44,7)$ & 1,03 & {$[0,59 ; 1,79]$} & 0,928 \\
\hline Mantida & $35(54,7)$ & $130(55,3)$ & 1 & & \\
\hline \multicolumn{6}{|l|}{ Parceiros na Vida ${ }^{5}$} \\
\hline$\geq 5$ & $8(12,5)$ & $19(8,0)$ & 1,64 & {$[0,68 ; 3,94]$} & 0,265 \\
\hline$<5$ & $56(87,5)$ & $218(92,0)$ & 1 & & \\
\hline \multicolumn{6}{|l|}{ Parceiros últimos 3 meses $^{6}$} \\
\hline$\geq 1$ & $58(92,1)$ & $204(86,4)$ & 1,82 & {$[0,68 ; 4,88]$} & 0,229 \\
\hline Nenhum & $5(7,9)$ & $32(13,6)$ & 1 & & \\
\hline \multicolumn{6}{|l|}{ Uso de Condom ${ }^{7}$} \\
\hline Raro/Ocasional & $53(85,5)$ & $181(78,4)$ & 1,63 & {$[0,75 ; 3,52]$} & 0,214 \\
\hline Sempre & $9(14,5)$ & $50(21,6)$ & 1 & & \\
\hline \multicolumn{6}{|l|}{ Contraceptivo Hormonal ${ }^{8}$} \\
\hline $\operatorname{Sim}$ & $43(68,3)$ & $144(61,5)$ & 1,34 & {$[0,74 ; 2,43]$} & 0,327 \\
\hline Não & $20(31,7)$ & $90(38,5)$ & 1 & & \\
\hline
\end{tabular}


Tabela 12 - Detecção de U. parvum Sorotipo 6 por meio da PCR em amostras de swab vaginal, e sua relação com o perfil das mulheres atendidas em unidades de saúde de Vitória da Conquista - BA, 2011.

(Conclusão)

\begin{tabular}{|c|c|c|c|c|c|}
\hline \multirow{5}{*}{ Variáveis } & U. parvum & U. parvum & \multirow{5}{*}{$\begin{array}{l}\text { Odds } \\
\text { Ratio } \\
\text { (bruta) }\end{array}$} & \multirow{5}{*}{ IC 95\% } & \multirow{5}{*}{$\mathbf{p}^{\star}$} \\
\hline & Sorotipo 6 & Sorotipo 6 & & & \\
\hline & PCR-Positivo & PCR-Negativo & & & \\
\hline & $N=64$ & $\mathrm{~N}=238$ & & & \\
\hline & n (\%) & $\mathrm{N}(\%)$ & & & \\
\hline \multicolumn{6}{|l|}{ Dispareunia $^{9}$} \\
\hline Sim & $16(25,4)$ & $76(33,2)$ & 0,68 & {$[0,36 ; 1,29]$} & 0,238 \\
\hline Não & $47(74,6)$ & $153(66,8)$ & 1 & & \\
\hline \multicolumn{6}{|l|}{ Sinusiorragia ${ }^{10}$} \\
\hline Sim & $6(9,7)$ & $20(8,7)$ & 1,13 & {$[0,43 ; 2,95]$} & 0,802 \\
\hline Não & $56(90,3)$ & $211(91,3)$ & 1 & & \\
\hline \multicolumn{6}{|l|}{ Disúria } \\
\hline Sim & $15(23,4)$ & $49(20,6)$ & 1,18 & {$[0,61 ; 2,28]$} & 0,620 \\
\hline Não & $49(76,6)$ & $189(79,4)$ & 1 & & \\
\hline \multicolumn{6}{|l|}{ Dor Pélvica } \\
\hline Sim & $30(46,9)$ & $105(44,1)$ & 1,12 & {$[0,64 ; 1,94]$} & 0,694 \\
\hline Não & $34(53,1)$ & $133(55,9)$ & 1 & & \\
\hline \multicolumn{6}{|l|}{ Prurido } \\
\hline Sim & $24(37,5)$ & $66(27,7)$ & 1,56 & {$[0,87 ; 2,79]$} & 0,129 \\
\hline Não & $40(62,5)$ & $172(72,3)$ & 1 & & \\
\hline \multicolumn{6}{|l|}{ Corrimento ${ }^{11}$} \\
\hline Sim & $29(45,3)$ & $105(44,3)$ & 1,04 & {$[0,59 ; 1,81]$} & 0,885 \\
\hline Não & $35(54,7)$ & $132(55,7)$ & 1 & & \\
\hline \multicolumn{6}{|l|}{ Sinais e Sintomas ${ }^{12}$} \\
\hline Sim & $52(81,2)$ & $184(78,0)$ & 1,22 & {$[0,61 ; 2,46]$} & 0,570 \\
\hline Não & $12(18,8)$ & $52(22,0)$ & 1 & & \\
\hline
\end{tabular}

Nota: Perda de observação: ${ }^{1}$ Motivo da consulta: perda de 1 ( $\left.n=301\right)$; ${ }^{2}$ Escolaridade: perda de $15(n=287) ;{ }^{3}$ Vida sexual: perda de $1(n=301) ;{ }^{4}$ Libido: perda de $3(n=$ 299); ${ }^{5}$ Parceiros na vida: perda de 1 ( $n=301$ ), ${ }^{6}$ Parceiros últimos três meses: perda de $3(n=299) ;{ }^{7}$ Uso de condom: perda de $9(n=293) ;{ }^{8}$ Contraceptivo hormonal: perda de $5(n=297)$; ${ }^{9}$ Dispaurenia: perda de 10 e excluídas mulheres com vida sexual inativa. ( $n=292)$; ${ }^{10}$ Sinusiorragia: perda de 9 e excluídas mulheres com vida sexual inativa $(n=293) ;{ }^{11}$ Corrimento: perda de $1(n=301) ;{ }^{12}$ Sinais e sintomas: perda de $2(n=300)$.

${ }^{*} \mathrm{p}$ valor: significante $\leq 0,05$. 
5.5.7 Perfil das mulheres que apresentaram U. parvum na qPCR

Do total das mulheres positivas para $U$. parvum por meio da $\mathrm{qPCR}$, houve associação significante com variáveis como vida sexual ativa (OR 3,25, IC 95\% 1,39; $7,57, p=0,004)$ e apresentar um ou mais parceiros sexuais nos últimos três meses (OR 3,79, IC 95\% 1,82; 7,88, p<0,001) (Tabela 13). 
Tabela 13 - Detecção de U. parvum por meio da qPCR, em amostras de swab vaginal, e sua relação com o perfil das mulheres atendidas em unidades de saúde de Vitória da Conquista - BA, 2011.

(Continua)

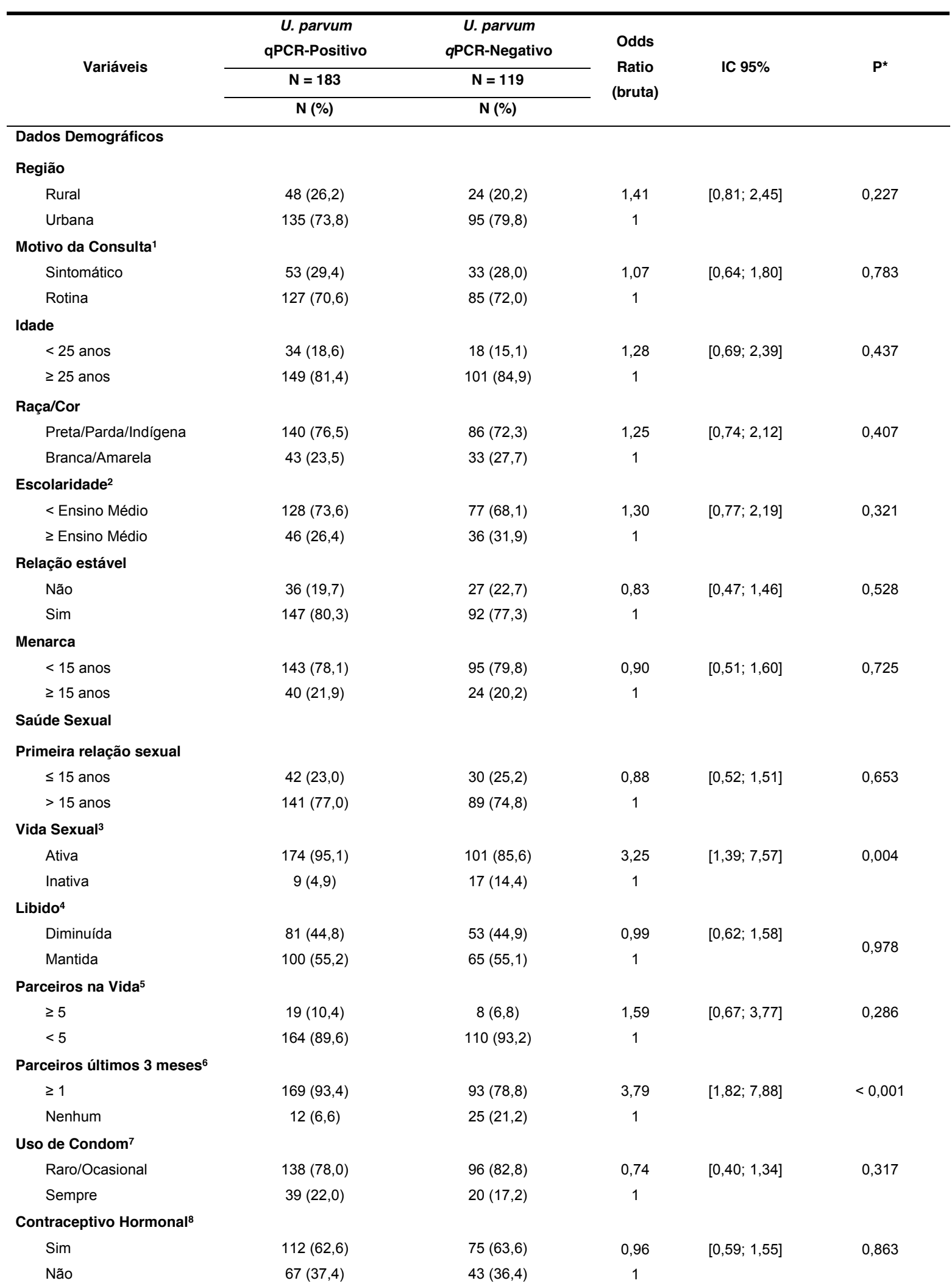


Tabela 13 - Deteç̧ão de U. parvum por meio da qPCR, em amostras de swab vaginal, e sua relação com o perfil das mulheres atendidas em unidades de saúde de Vitória da Conquista - BA, 2011.

(Conclusão)

\begin{tabular}{|c|c|c|c|c|c|}
\hline \multirow{3}{*}{ Variáveis } & $\begin{array}{c}\text { U. parvum } \\
\text { qPCR-Positivo }\end{array}$ & $\begin{array}{c}\text { U. parvum } \\
\text { qPCR-Negativo }\end{array}$ & \multirow{3}{*}{$\begin{array}{l}\text { Odds } \\
\text { Ratio } \\
\text { (bruta) }\end{array}$} & \multirow{3}{*}{ IC 95\% } & \multirow{3}{*}{$\mathbf{P}^{*}$} \\
\hline & $N=183$ & $N=119$ & & & \\
\hline & $\mathrm{n}(\%)$ & n (\%) & & & \\
\hline \multicolumn{6}{|l|}{ Dispareunia $^{9}$} \\
\hline $\operatorname{Sim}$ & $61(34,1)$ & $31(27,4)$ & 1,37 & {$[0,82 ; 2,29]$} & 0,234 \\
\hline Não & $118(65,9)$ & $82(72,6)$ & 1 & & \\
\hline \multicolumn{6}{|l|}{ Sinusiorragia ${ }^{10}$} \\
\hline Sim & $16(8,9)$ & $10(8,8)$ & 1,00 & {$[0,44 ; 2,99]$} & 0,991 \\
\hline Não & $164(91,1)$ & $103(91,2)$ & 1 & & \\
\hline \multicolumn{6}{|l|}{ Disúria } \\
\hline Sim & $42(23,0)$ & $22(18,5)$ & 1,31 & {$[0,74 ; 2,34]$} & 0,354 \\
\hline Não & $141(77,0)$ & $97(81,5)$ & 1 & & \\
\hline \multicolumn{6}{|c|}{ Sinais e Sintomas ${ }^{12}$} \\
\hline Sim & $149(81,9)$ & $87(73,7)$ & 1,61 & {$[0,92 ; 2,81]$} & 0,093 \\
\hline Não & $33(18,1)$ & $31(26,3)$ & 1 & & \\
\hline \multicolumn{6}{|l|}{ Prurido } \\
\hline Sim & $61(33,3)$ & $29(24,4)$ & 1,55 & {$[0,92 ; 2,61]$} & 0,096 \\
\hline Não & $122(66,7)$ & $90(75,6)$ & 1 & & \\
\hline \multicolumn{6}{|l|}{ Corrimento ${ }^{11}$} \\
\hline Sim & $89(48,9)$ & $45(37,8)$ & 1,57 & {$[0,98 ; 2,52]$} & 0,058 \\
\hline Não & $93(51,1)$ & $74(62,2)$ & 1 & & \\
\hline \multicolumn{6}{|c|}{ Sinais e Sintomas ${ }^{12}$} \\
\hline Sim & $149(81,9)$ & $87(73,7)$ & 1,61 & {$[0,92 ; 2,81]$} & 0,093 \\
\hline Não & $33(18,1)$ & $31(26,3)$ & 1 & & \\
\hline
\end{tabular}

Nota: Perda de observação: ${ }^{1}$ Motivo da consulta: perda de 1 ( $\left.n=301\right)$; ${ }^{2}$ Escolaridade: perda de $15(n=287)$; ${ }^{3}$ Vida sexual: perda de $1(n=301) ;{ }^{4}$ Libido: perda de $3(n=$ 299); ${ }^{5}$ Parceiros na vida: perda de $1(n=301)$, ${ }^{6}$ Parceiros últimos três meses: perda de 3 ( $n=299)$; ${ }^{7}$ Uso de condom: perda de 9 ( $\left.n=293\right)$; ${ }^{8}$ Contraceptivo hormonal: perda de $5(n=297)$; ${ }^{9}$ Dispaurenia: perda de 10 e excluídas mulheres com vida sexual inativa. ( $n=292)$; ${ }^{10}$ Sinusiorragia: perda de 9 e excluídas mulheres com vida sexual inativa $(n=293) ;{ }^{11}$ Corrimento: perda de $1(n=301) ;{ }^{12}$ Sinais e sintomas: perda de $2(n=300)$.

${ }^{*} p$ valor: significante $\leq 0,05$. 
5.5.8 Perfil das mulheres com ou sem sinais elou sintomas em relação à presença $U$. urealyticum e U. parvum detectados por PCR convencional e $q P C R$

Ao estratificar em dois grupos, mulheres que referiram sintomas e/ou apresentaram sinais de infecção urogenital com aquelas que não tinham nenhuma dos dois fatores, foi possível analisar a possível relação com os achados para as duas técnicas de PCR. Não foi encontrada associação significante entre a presença de U. urealyticum e U. parvum, e a presença de sinais e/ou sintomas (Tabela 14).

Tabela 14 - Perfil das mulheres com e sem sinais e/ou sintomas em relação à presença de Mollicutes, $U$. urealyticum e $U$. parvum detectados por PCR convencional e qPCR em amostras de swab vaginal de mulheres atendidas em unidades de saúde de Vitória da Conquista - BA, 2011.

\begin{tabular}{|c|c|c|c|c|c|}
\hline \multirow{4}{*}{ Variáveis } & Sinais e Sintomas & Sinais e sintomas & \multirow{4}{*}{$\begin{array}{l}\text { Odds } \\
\text { Ratio } \\
\text { (bruta) }\end{array}$} & \multirow{4}{*}{ IC 95\% } & \multirow{4}{*}{$\mathbf{P}^{*}$} \\
\hline & Positivo & Negativo & & & \\
\hline & $N=236$ & $N=64$ & & & \\
\hline & n (\%) & n (\%) & & & \\
\hline \multicolumn{6}{|l|}{ U. urealyticum PCR } \\
\hline Positivo & $16(6,8)$ & $5(7,8)$ & 0,86 & {$[0,30 ; 2,44]$} & 0,774 \\
\hline Negativo & $220(93,2)$ & $59(92,2)$ & 1 & & \\
\hline \multicolumn{6}{|l|}{ U. parvum PCR } \\
\hline Positivo & $130(55,1)$ & $27(42,2)$ & 1,68 & {$[0,96 ; 2,94]$} & 0,067 \\
\hline Negativo & $106(44,9)$ & $37(57,8)$ & 1 & & \\
\hline \multicolumn{6}{|l|}{ U. parvum Sorotipo 1} \\
\hline Positivo & $31(13,1)$ & $6(9,4)$ & 1,46 & {$[0,58 ; 3,67]$} & 0,417 \\
\hline Negativo & $205(86,9)$ & $58(90,6)$ & 1 & & \\
\hline \multicolumn{6}{|c|}{ U. parvum Sorotipo 3 e 14} \\
\hline Positivo & $52(22,0)$ & $10(15,6)$ & 1,53 & {$[0,73 ; 3,20]$} & 0,261 \\
\hline Negativo & $184(78,0)$ & $54(84,4)$ & 1 & & \\
\hline \multicolumn{6}{|l|}{ U. parvum Sorotipo 6} \\
\hline Positivo & $52(22,0)$ & $12(18,8)$ & 1,22 & {$[0,61 ; 2,46]$} & 0,570 \\
\hline Negativo & $184(78,0)$ & $52(81,2)$ & 1 & & \\
\hline \multicolumn{6}{|l|}{ U. urealyticum qPCR } \\
\hline Positivo & $41(17,4)$ & $9(14,1)$ & 1,28 & {$[0,58 ; 2,81]$} & 0,529 \\
\hline Negativo & $195(82,6)$ & $55(85,9)$ & 1 & & \\
\hline \multicolumn{6}{|l|}{ U. parvum qPCR } \\
\hline Positivo & $149(63,1)$ & $33(51,6)$ & 1,61 & {$[0,92 ; 2,81]$} & 0,093 \\
\hline Negativo & $87(36,9)$ & $31(48,4)$ & 1 & & \\
\hline
\end{tabular}

Nota: * $p$ valor: significante $\leq 0,05$. 


\subsubsection{Perfil clínico-demográfico das mulheres com e sem sinais e/ou sintomas}

A presença de sinais e/ou sintomas foi relacionada com as variáveis demográficas e de saúde sexual, para descrever o perfil das mulheres que referiram sintomas e/ou apresentavam sinais de infecção. As mulheres que viviam na região rural do município apresentaram associação positiva (OR 3,03, IC $95 \% 1,31-6,98, p=0,007$ ), assim como mulheres que buscaram o serviço de saúde por motivo sintomático (OR 11,32, IC 95\% 3,44 - 37,22, p < 0,001); com idade inferior a 25 anos (OR 2,93, IC 95\% 1,11-7,71, p = 0,023); que tiveram a primeira relação sexual com idade menor ou igual a 15 anos (OR 2,22, IC 95\% 1,03 - 4,76, $p=0,036$ ); sexualmente ativas (OR 2,59, IC 95\% 1,11-6,04, $p=0,023$ ); com um ou mais parceiros sexuais nos últimos três meses (OR 2,62, IC 95\% 1,25; $5,45 p=0,008$ ); que utilizam contraceptivo hormonal (OR 2,00, IC 95\% 1,07 - 3,73, $p=0,028$ ); que relatam sinusiorragia (OR 7,16, IC 95\% 0,95-53,95, $p=0,027$ ), dor pélvica (OR 4,05, IC 95\% 2,09 - 7,85, $p<0,001$ ), e apresentavam corrimento vaginal (OR 80,7, IC 95\% 11,0 - 591,9, $p<0,001$ ) (Tabela 15). 
Tabela 15 - Perfil clínico-demográfico das mulheres com e sem sinais e/ou sintomas de infecção urogenital atendidas em unidades de saúde de Vitória da Conquista - BA, 2011.

(continua)

\begin{tabular}{|c|c|c|c|c|c|}
\hline \multirow{4}{*}{ Variáveis } & Sinais e Sintomas & Sinais e Sintomas & \multirow{4}{*}{$\begin{array}{l}\text { Odds } \\
\text { Ratio } \\
\text { (bruta) }\end{array}$} & \multirow{4}{*}{ IC 95\% } & \multirow{4}{*}{$\mathbf{P}^{*}$} \\
\hline & rositivo & Negativo & & & \\
\hline & $N=236$ & $N=64$ & & & \\
\hline & n (\%) & n (\%) & & & \\
\hline \multicolumn{6}{|l|}{ Dados Demográficos } \\
\hline \multicolumn{6}{|l|}{ Região } \\
\hline Rural & $64(27,1)$ & $7(10,9)$ & 3,03 & {$[1,31 ; 6,98]$} & 0,007 \\
\hline Urbana & $172(72,9)$ & $57(89,1)$ & 1 & & \\
\hline \multicolumn{6}{|l|}{ Motivo da Consulta ${ }^{1}$} \\
\hline Sintomático & $83(35,8)$ & $3(4,7)$ & 11,32 & {$[3,44 ; 37,22]$} & $<0,001$ \\
\hline Rotina & $149(64,2)$ & $61(95,3)$ & 1 & & \\
\hline \multicolumn{6}{|l|}{ Idade } \\
\hline$<25$ anos & $47(19,9)$ & $5(7,8)$ & 2,93 & {$[1,11 ; 7,71]$} & 0,023 \\
\hline$\geq 25$ anos & $189(80,1)$ & $59(92,2)$ & 1 & & \\
\hline \multicolumn{6}{|l|}{ Raça/Cor } \\
\hline Preta/Parda/Indígena & $175(74,2)$ & $51(79,7)$ & 0,73 & {$[0,37 ; 1,43]$} & 0,362 \\
\hline Branca/Amarela & $61(25,8)$ & $13(20,3)$ & 1 & & \\
\hline \multicolumn{6}{|l|}{ Escolaridade $^{2}$} \\
\hline < Ensino Médio & $159(70,4)$ & $44(74,6)$ & 0,80 & {$[0,42 ; 1,55]$} & 0,523 \\
\hline$\geq$ Ensino Médio & $67(29,6)$ & $15(25,4)$ & 1 & & \\
\hline \multicolumn{6}{|l|}{ Relação estável } \\
\hline Não & $47(19,9)$ & $16(25,0)$ & 0,74 & {$[0,39 ; 1,42]$} & 0,376 \\
\hline Sim & $189(80,1)$ & $48(75,0)$ & 1 & & \\
\hline \multicolumn{6}{|l|}{ Menarca } \\
\hline$<15$ anos & $189(78,8)$ & $50(78,1)$ & 1,04 & {$[0,53 ; 2,03]$} & 0,905 \\
\hline$\geq 15$ anos & $50(21,2)$ & $14(21,9)$ & 1 & & \\
\hline \multicolumn{6}{|l|}{ Saúde Sexual } \\
\hline \multicolumn{6}{|l|}{ Primeira relação sexual } \\
\hline$\leq 15$ anos & $63(26,7)$ & $9(14,1)$ & 2,22 & {$[1,03 ; 4,76]$} & 0,036 \\
\hline$>15$ anos & $173(73,3)$ & $55(85,9)$ & 1 & & \\
\hline \multicolumn{6}{|l|}{ Vida Sexual ${ }^{3}$} \\
\hline Ativa & $220(93,2)$ & $53(84,1)$ & 2,59 & {$[1,11 ; 6,04]$} & 0,023 \\
\hline Inativa & $16(6,8)$ & $10(15,9)$ & 1 & & \\
\hline \multicolumn{6}{|l|}{ Libido $^{4}$} \\
\hline Diminuída & $107(45,5)$ & $26(41,9)$ & 1,15 & {$[0,65 ; 2,03]$} & 0,612 \\
\hline Mantida & $128(54,5)$ & $36(58,1)$ & 1 & & \\
\hline \multicolumn{6}{|l|}{ Parceiros na Vida ${ }^{5}$} \\
\hline$\geq 5$ & $25(10,6)$ & $2(3,2)$ & 3,61 & {$[0,83 ; 15,68]$} & 0,068 \\
\hline$<5$ & $211(89,4)$ & $61(96,8)$ & 1 & & \\
\hline
\end{tabular}


Tabela 15 - Perfil clínico-demográfico das mulheres com e sem sinais e/ou sintomas de infecção urogenital atendidas em unidades de saúde de Vitória da Conquista - BA, 2011.

(conclusão)

\begin{tabular}{|c|c|c|c|c|c|}
\hline Variáveis & $\begin{array}{c}\text { Sinais e Sintomas } \\
\text { Positivo } \\
\mathrm{N}=\mathbf{2 3 6} \\
\mathbf{n}(\%)\end{array}$ & $\begin{array}{c}\begin{array}{c}\text { Sinais e Sintomas } \\
\text { Negativo }\end{array} \\
\mathrm{N}=64 \\
\mathrm{n}(\%)\end{array}$ & $\begin{array}{l}\text { Odds } \\
\text { Ratio } \\
\text { (bruta) }\end{array}$ & IC 95\% & $\mathbf{P}^{*}$ \\
\hline \multicolumn{6}{|c|}{ Parceiros últimos 3 meses $^{6}$} \\
\hline$\geq 1$ & $211(90,2)$ & $49(77,8)$ & 2,62 & {$[1,25 ; 5,45]$} & 0,008 \\
\hline Nenhum & $23(9,8)$ & $14(22,2)$ & 1 & & \\
\hline \multicolumn{6}{|l|}{ Uso de Condom ${ }^{7}$} \\
\hline Raro/Ocasional & $196(83,8)$ & $53(93,0)$ & 0,38 & {$[0,13 ; 1,13]$} & 0,076 \\
\hline Sempre & $38(16,2)$ & $4(7,0)$ & 1 & & \\
\hline \multicolumn{6}{|c|}{ Contraceptivo Hormonal ${ }^{8}$} \\
\hline Sim & $94(40,5)$ & $16(25,4)$ & 2,00 & {$[1,07 ; 3,73]$} & 0,028 \\
\hline Não & $138(59,5)$ & $47(74,6)$ & 1 & & \\
\hline \multicolumn{6}{|l|}{ Dispareunia $^{9}$} \\
\hline Sim & $90(38,8)$ & $0(0,0)$ & -- & -- & -- \\
\hline Não & $142(61,2)$ & $58(100,0)$ & & & \\
\hline \multicolumn{6}{|l|}{ Sinusiorragia ${ }^{10}$} \\
\hline Sim & $25(10,8)$ & $1(1,7)$ & 7,16 & {$[0,95 ; 53,95]$} & 0,027 \\
\hline Não & $206(89,2)$ & $59(98,3)$ & 1 & & \\
\hline \multicolumn{6}{|l|}{ Disúria } \\
\hline Sim & $63(26,7)$ & $0(0,0)$ & -- & -- & -- \\
\hline Não & $173(73,3)$ & $64(100,0)$ & & & \\
\hline \multicolumn{6}{|l|}{ Dor Pélvica } \\
\hline $\operatorname{Sim}$ & $120(50,8)$ & $13(20,3)$ & 4,05 & {$[2,09 ; 7,85]$} & $<0,001$ \\
\hline Não & $116(49,2)$ & $51(79,7)$ & 1 & & \\
\hline \multicolumn{6}{|l|}{ Prurido } \\
\hline Sim & $89(37,7)$ & $0(0,0)$ & -- & -- & -- \\
\hline Não & $147(62,3)$ & $64(100,0)$ & & & \\
\hline \multicolumn{6}{|l|}{ Corrimento'11 } \\
\hline Sim & $132(56,2)$ & $1(1,6)$ & 80,7 & {$[11,0 ; 591,9]$} & $<0,001$ \\
\hline Não & $103(43,8)$ & $63(98,4)$ & 1 & & \\
\hline
\end{tabular}

Nota: Perda de observação: ${ }^{1}$ Motivo da consulta: perda de 1 ( $\left.n=301\right)$; ${ }^{2}$ Escolaridade: perda de 15 ( $n=287)$; ${ }^{3}$ Vida sexual: perda de $1(n=301)$; ${ }^{4}$ Libido: perda de $3(n=$ 299); ${ }^{5}$ Parceiros na vida: perda de $1(n=301)$, ${ }^{6}$ Parceiros últimos três meses: perda de 3 ( $n=299)$; ${ }^{7}$ Uso de condom: perda de $9(n=293) ;{ }^{8}$ Contraceptivo hormonal: perda de $5(n=297)$; ${ }^{9}$ Dispaurenia: perda de 10 e excluídas mulheres com vida sexual inativa. ( $n=292) ;{ }^{10}$ Sinusiorragia: perda de 9 e excluídas mulheres com vida sexual inativa $(n=293) ;{ }^{11}$ Corrimento: perda de $1(n=301) ;{ }^{12}$ Sinais e sintomas: perda de $2(n=300)$.

${ }^{*} p$ valor: significante $\leq 0,05$. 


\subsubsection{Análise multivariada da detecção de Mollicutes, U. urealyticum e U.} parvum, e sinais e sintomas nas mulheres atendidas

Um modelo de regressão logística foi desenvolvido para avaliar a contribuição independente das variáveis associadas com a infecção por Mollicutes, $U$. urealyticum, U. parvum, G. vaginalis, N. gonorrhoeae e sinais e sintomas (Tabelas 16 e 17).

As variáveis região rural de residência e número de parceiros sexuais nos últimos três meses foram associados ao aumento da chance de ter infecção por Mollicutes. Mulheres sem relação estável e que apresentaram a menarca até os 15 anos tiveram menores chances de ter Mollicutes. Da mesma maneira, as variáveis ser da região rural, apresentar cinco ou mais parceiros sexuais durante a vida e ter relação sexual com um ou mais parceiros nos últimos três meses foram associados com aumento das chances de ter PCR-positivo para $U$. urealyticum.

Mulheres com vida sexual ativa, que relataram um ou mais parceiros sexuais nos últimos três meses, com sinais e/ou sintomas sugestivos de IST, dor pélvica, prurido e corrimento também apresentaram associação com aumento de chance de ter $U$. parvum. O maior risco para infecção por $U$. parvum sorotipo 1 foi associado a região rural de residência, grau de escolaridade (Ensino Médio incompleto), disúria e dor pélvica. Apresentar menarca até os 15 anos de idade foi associado com redução da chance de apresentar $U$. parvum sorotipo 1. No entanto, para U. parvum sorotipo $3 / 14$, maiores riscos de infecção foi associado ao número de parceiros sexuais nos últimos três meses e a presença do sintoma corrimento. Além disso, a presença de sinais e/ou sintomas sugestivos de IST reduzem a chance de apresentar o sorotipo $3 / 14$.

As variáveis, região rural de residência e presença de algum sinal e/ou sintoma sugestivo de IST foram associados com menores chances de ter infecção com $N$. gonorrhoeae, e o sintoma sinusiorragia aumentou a chance de infecção. No entanto, mulheres com idade inferior a 25 anos, sintomáticas, de vida sexual ativa, com primeira relação sexual até os 15 anos de idade e com dispaurenia têm maior chance de apresentar $G$. vaginalis na região cérvico-vaginal. E mulheres com idade inferior a 25 anos, que moram na região rural, sexualmente ativas, que tiveram relação sexual antes dos 15 anos, com parceiros nos últimos três meses e dor 
pélvica têm risco maior de apresentar sinais e/ou sintomas de infecção vaginal. As outras variáveis não foram significativas e foram retiradas do modelo final. 
Tabela 16 - Análise multivariada dos fatores de risco para detecção vaginal de Mollicutes, U. urealyticum e U. parvum em mulheres atendidas em Unidades de saúde de Vitória da Conquista - BA.

\begin{tabular}{|c|c|c|c|c|c|c|c|c|c|c|}
\hline \multirow{2}{*}{$\begin{array}{l}\text { Modelo de Regressão } \\
\text { Logística Multivariada }\end{array}$} & \multicolumn{2}{|c|}{$\begin{array}{c}\text { PCR } \\
\text { Mollicutes }\end{array}$} & \multicolumn{2}{|c|}{$\begin{array}{c}\text { PCR } \\
U . \text { urealyticum }\end{array}$} & \multicolumn{2}{|c|}{$\begin{array}{c}\text { qPCR } \\
U . \text { urealyticum }\end{array}$} & \multicolumn{2}{|c|}{$\begin{array}{c}\text { PCR } \\
\text { U. parvum }\end{array}$} & \multicolumn{2}{|c|}{$\begin{array}{c}\text { qPCR } \\
\text { U. parvum }\end{array}$} \\
\hline & OR & $95 \%$ IC & OR & $95 \%$ IC & OR & $95 \%$ IC & OR & $95 \%$ IC & OR & $95 \%$ IC \\
\hline Região (Rural) & 1,9 & {$[0,8-4,2]$} & 3,2 & {$[1,2-8,5]$} & 2,4 & {$[1,2-4,6]$} & -- & -- & -- & -- \\
\hline Relação estável & 0,9 & {$[0,4-2,1]$} & -- & -- & 0,7 & {$[0,2-2,0]$} & -- & -- & -- & -- \\
\hline $\begin{array}{c}\text { Menarca } \\
(<15 \text { anos })\end{array}$ & 0,5 & {$[0,2-1,1]$} & -- & -- & -- & -- & -- & -- & -- & -- \\
\hline Vida Sexual (Ativa) & -- & -- & -- & -- & -- & -- & 2,0 & {$[0,6-6,9]$} & 1,8 & {$[0,5-5,9]$} \\
\hline $\begin{array}{c}\text { Parceiros Vida } \\
\qquad(\geq 5)\end{array}$ & -- & -- & 3,8 & {$[1,1-13,2]$} & -- & -- & -- & -- & -- & -- \\
\hline $\begin{array}{l}\text { Parceiros últimos } \\
3 \text { meses }(\geq 1)\end{array}$ & 3,8 & {$[1,6-9,4]$} & -- & -- & 5,3 & {$[0,6-44,1]$} & 1,9 & {$[0,7-5,0]$} & 2,6 & {$[0,9-6,8]$} \\
\hline Sintomas & -- & -- & -- & -- & -- & -- & 1,1 & {$[0,5-2,1]$} & 0,9 & {$[0,5-1,9]$} \\
\hline Dor Pélvica & -- & -- & -- & -- & -- & -- & 1,3 & {$[0,7-2,1]$} & & \\
\hline Prurido & -- & -- & -- & -- & -- & -- & 1,5 & {$[0,8-2,6]$} & 1,5 & {$[0,8-2,6]$} \\
\hline Corrimento & -- & -- & -- & -- & -- & -- & 1,1 & {$[0,7-1,9]$} & 1,3 & {$[0,7-2,3]$} \\
\hline
\end{tabular}

Nota: OR: Odda Ratio; IC: Intervalo de Confiança. 
Tabela 17 - Análise multivariada dos fatores de risco para detecção vaginal dos sorotipos U. parvum, G. vaginalis, $N$. gonorrhoeae e sinais e sintomas em mulheres atendidas em Unidades de saúde de Vitória da Conquista - BA.

\begin{tabular}{|c|c|c|c|c|c|c|c|c|c|c|}
\hline \multirow{2}{*}{$\begin{array}{l}\text { Modelo de Regressão } \\
\text { Logística Multivariada }\end{array}$} & \multicolumn{2}{|c|}{$\begin{array}{l}\text { U. parvum } \\
\text { Sorotipo } 1\end{array}$} & \multicolumn{2}{|c|}{$\begin{array}{c}\text { U. parvum } \\
\text { Sorotipo } 3 / 14\end{array}$} & \multicolumn{2}{|c|}{$\begin{array}{c}\text { PCR } \\
\text { G. vaginalis }\end{array}$} & \multicolumn{2}{|c|}{$\begin{array}{c}\text { PCR } \\
\text { N. gonorrhoeae }\end{array}$} & \multicolumn{2}{|c|}{$\begin{array}{c}\text { Casos } \\
\text { Sinais e Sintomas }\end{array}$} \\
\hline & OR & $95 \%$ IC & OR & $95 \%$ IC & OR & $95 \%$ IC & OR & $95 \%$ IC & OR & $95 \%$ IC \\
\hline Região (Rural) & 3,4 & {$[1,6-7,3]$} & -- & -- & 0,6 & {$[0,3-1,1]$} & 0,1 & {$[0,02-0,3]$} & 2,5 & {$[1,0-6,2]$} \\
\hline Motivo consulta & -- & -- & -- & -- & 1,6 & {$[0,8-2,8]$} & -- & -- & -- & -- \\
\hline Idade (<25 anos) & -- & -- & -- & -- & 2,3 & {$[1,1-4,4]$} & -- & -- & 1,2 & {$[1,2-9,7]$} \\
\hline $\begin{array}{c}\text { Escolaridade } \\
\text { (< Ensino Médio) }\end{array}$ & 1,6 & {$[0,6-4,2]$} & -- & -- & 0,7 & {$[0,4-1,2]$} & -- & -- & -- & -- \\
\hline Menarca (< 15 anos) & 0,6 & {$[0,2-1,5]$} & -- & -- & -- & -- & -- & -- & -- & -- \\
\hline Vida Sexual (Ativa) & -- & -- & -- & -- & 1,9 & {$[0,6-6,3]$} & -- & -- & 1,2 & {$[0,3-5,0]$} \\
\hline Primeira relação ( $\leq 15$ anos) & -- & -- & -- & -- & 1,6 & {$[0,8-2,9]$} & -- & -- & 1,6 & {$[0,7-3,6]$} \\
\hline $\begin{array}{l}\text { Parceiros últimos } 3 \text { meses } \\
\qquad(\geq 1)\end{array}$ & -- & -- & 4,6 & {$[1,1-19,8]$} & -- & -- & -- & -- & 1,8 & {$[0,5-5,9]$} \\
\hline Sintomas & -- & -- & 0,9 & {$[0,4-2,2]$} & -- & -- & 0,4 & {$[0,2-0,8]$} & -- & -- \\
\hline Dispaurenia & -- & -- & -- & -- & 1,5 & {$[0,8-2,7]$} & -- & -- & -- & -- \\
\hline Sinusiorragia & -- & -- & -- & -- & -- & -- & 3,6 & {$[1,4-9,2]$} & -- & -- \\
\hline Disúria & 1,9 & {$[0,8-4,4]$} & -- & -- & -- & -- & -- & -- & -- & -- \\
\hline Dor Pélvica & 1,3 & {$[0,6-2,8]$} & -- & -- & -- & -- & -- & -- & 4,1 & {$[2,0-8,3]$} \\
\hline Corrimento & -- & -- & 1,8 & {$[0,9-3,4]$} & -- & -- & -- & -- & -- & -- \\
\hline
\end{tabular}

Nota: OR: Odda Ratio; IC: Intervalo de Confiança. 


\subsection{Análise dos polimorfismos genômico das citocinas}

5.6.1 Detecção de polimorfismo genético da Interleucina-6 (IL-6) por meio da MS$P C R$

Para o polimorfismo genético da IL-6, foi realizada a MS-PCR. A Figura 7 apresenta os perfis das bandas obtidos na reação correspondente a cada um dos genótipos (homozigoto CC com banda única de 136 pb, heterozigoto GC com duas bandas sendo uma de 121 pb e outra de 136 pb e o genótipo homozigoto GG com uma banda de $121 \mathrm{pb}$ ). A eletroforese ocorreu em gel de agarose a 4\% para permitir melhor separação das bandas. O genótipo GG foi o mais frequente na população estudada (61,9\%), seguido pelo genótipo GC $(32,8 \%)$ e o genótipo CC $(5,3 \%)$ (Tabela 13).

Figura 7 - Eletroforese em gel de agarose dos produtos da MS-PCR evidenciando três perfis de polimorfismos genéticos da região gênica onde ocorre a mutação pontual na citocina IL-6.

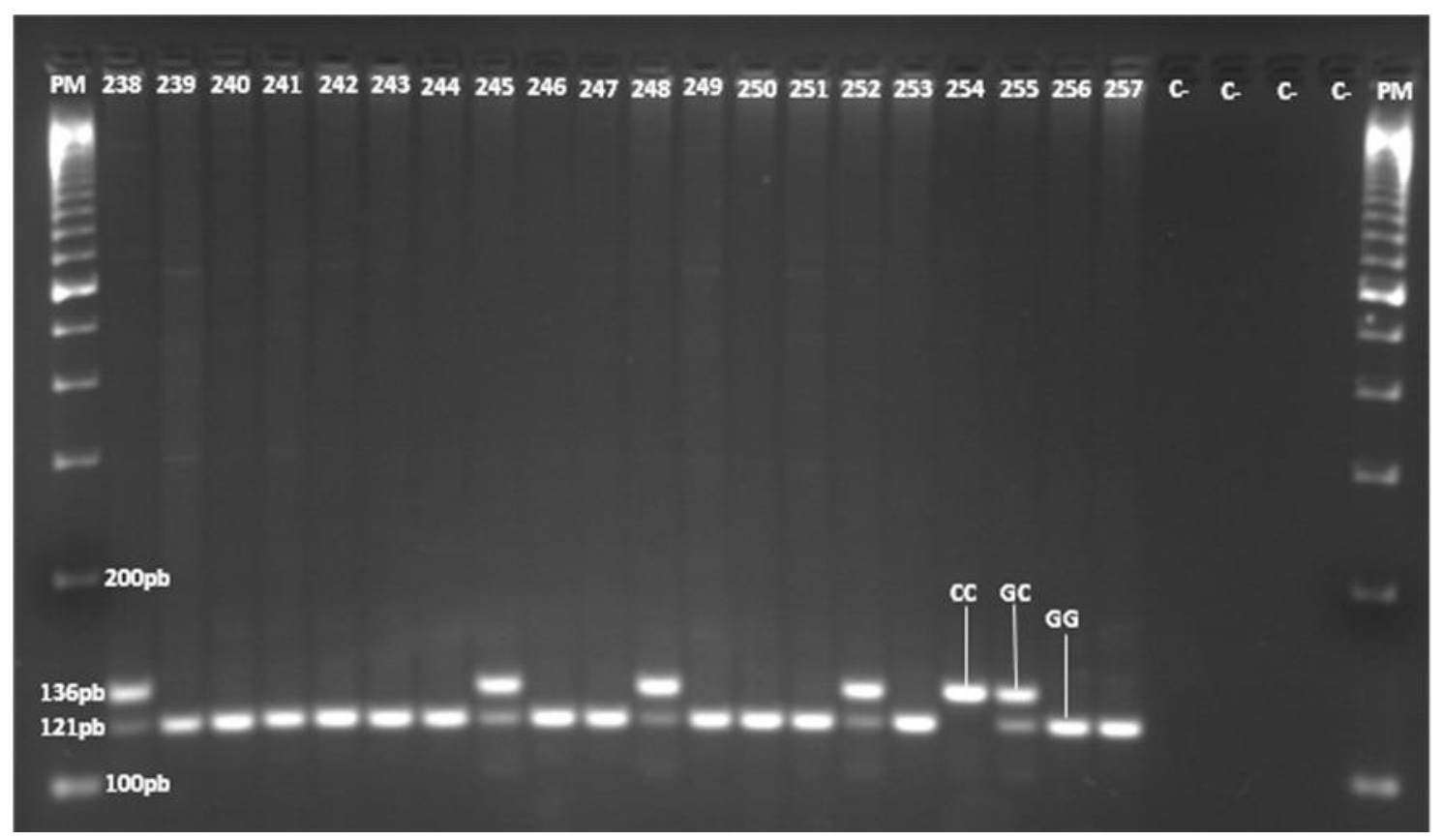

Legenda: Colunas 239 a 244; 246, 247, 249 a 251, 253, 256 e 257: genótipo GG (121pb); Coluna: 238, 245, 248, 252 e 255: genótipo GC (136pb e 121pb); Coluna 254: genótipo CC (136pb). C-: Controle Negativo. PM: Peso Molecular (100 pb). 


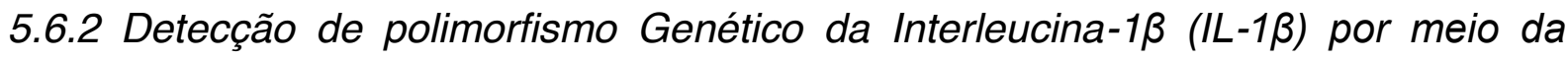
PCR RFLP

A detecção do polimorfismo genético da IL-1ß inicia-se pela amplificação por PCR da região gênica onde ocorre a mutação, gerando um produto de 182 pb (Figura 8).

Figura 8 - Eletroforese em gel de agarose dos produtos amplificados na PCR, da região gênica onde ocorre a mutação pontual, utilizando "primers" P1 e P2 com DNA das amostras de sangue coletadas das mulheres.

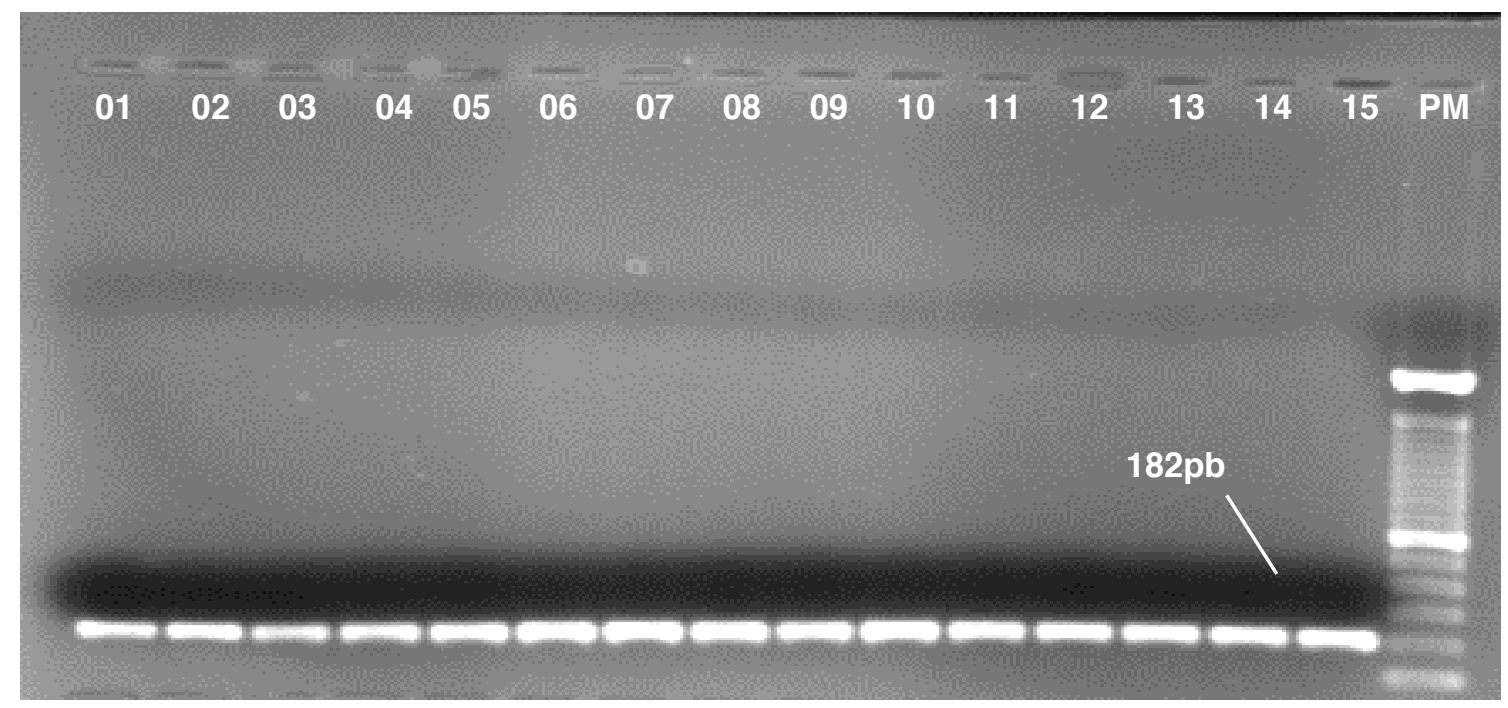

Legenda: Colunas 01 a 15: amostras amplificadas; PM: Peso Molecular (100 pb).

O material amplificado foi digerido pela enzima de restrição Taql, e assim se obteve a distribuição dos alelos. Três perfis de fragmentos eram esperados após a digestão: homozigoto TT com fragmento de 182 pb, homozigoto CC com dois fragmentos: um de 97 pb e um de 85 pb, e heterozigoto CT com três fragmentos: uma de 182 pb, uma de 97 pb e uma de 85 pb. Na Figura 9, os três perfis genéticos estão apresentados. 
Figura 9 - Eletroforese em gel de agarose dos produtos da PCR-RFLP evidenciando três perfis de polimorfismos genéticos da região gênica onde ocorre a mutação pontual na citocina IL-1 $\beta$.

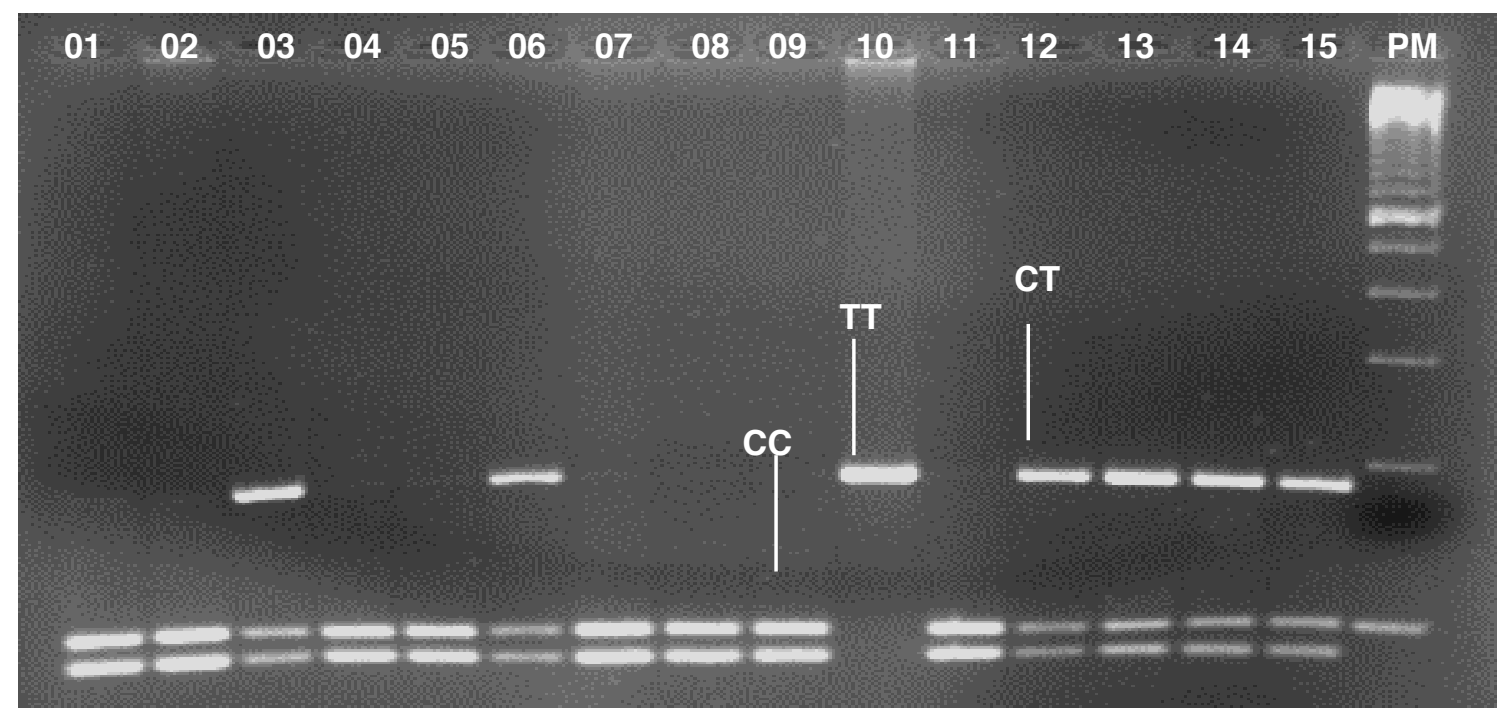

Legenda: Colunas 01, 02, 04, 05, 07 a 09 e 11: genótipo CC (85pb e 97 pb); Coluna: 03, 06, 12 a 15: genótipo CT (182 pb, 97 pb e 85 pb); Coluna 10: genótipo TT (182 pb). PM: Peso Molecular (100pb).

A Tabela 18 apresenta a frequência de cada genótipo encontrado nas amostras. O genótipo $\mathrm{CC}$ foi encontrado com maior frequência na população estudada $(63,6 \%)$, seguido pelo genótipo CT $(34,4 \%)$ e por fim, o genótipo TT $(2,0 \%)$. Os polimorfismos foram confirmados pelo sequenciamento dos fragmentos dos genes IL-6 e IL-1 $\beta$ como evidenciado na Figura 10.

Tabela 18 - Frequência dos genótipos das interleucinas IL-6 e IL-1 $\beta$ para seus respectivos polimorfismos encontrados em amostras de sangue de mulheres atendidas em unidades de saúde de Vitória da Conquista BA, 2011.

\begin{tabular}{ccccc}
\hline Genótipo & IL-6 & & Genótipo & IL-1 $\boldsymbol{\beta}$ \\
\cline { 2 - 2 } \cline { 5 - 5 } & $\mathbf{n ~ ( \% )}$ & & $\mathbf{n ~ ( \% )}$ \\
\hline Homozigoto CC & $16(5,3)$ & & Homozigoto CC & $192(63,6)$ \\
Homozigoto GG & $187(61,9)$ & & Homozigoto TT & $06(2,0)$ \\
Heterozigoto GC & $99(32,8)$ & & Heterozigoto CT & $104(34,4)$ \\
\hline
\end{tabular}

Nota: $\mathrm{n}=302$ amostras 
Figura 10 - Eletroesferograma parcial da reação de sequenciamento dos fragmentos dos genes IL-6 e IL-1 $\beta$ evidenciando as regiões dos polimorfismos $\mathrm{C}-174 \mathrm{C}>\mathrm{G}$ e c- $+3954 \mathrm{C}>\mathrm{T}$.
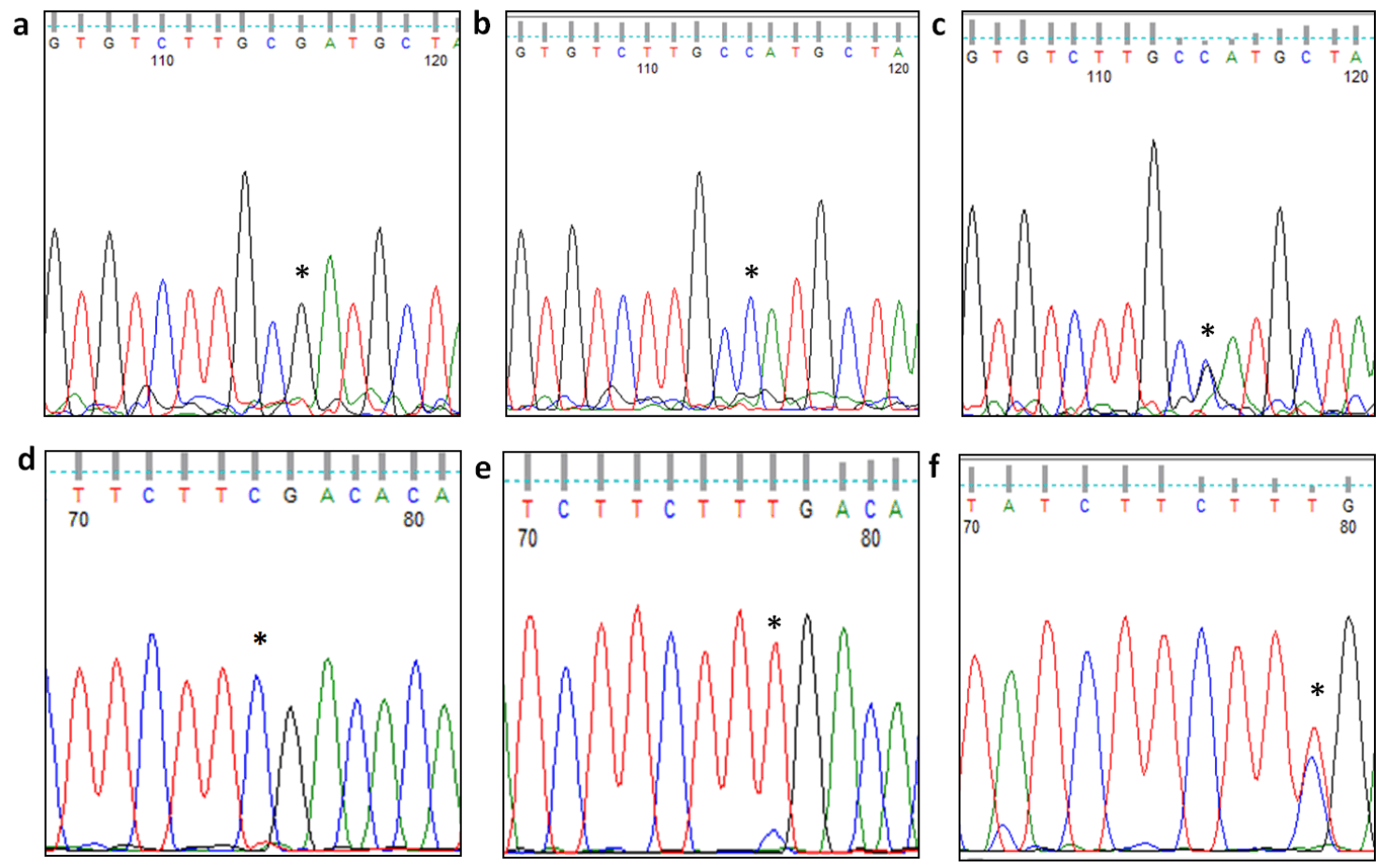

Legenda: a. Indivíduo homozigoto GG para o gene IL-6 (+ 3954 C>T). b. Indivíduo homozigoto CC para o gene IL-6 + 3954 C>T. c. Indivíduo heterozigoto GC + 3954 C>T. d. Indivíduo homozigoto CC para o gene IL-1B - $174 \mathrm{C}>\mathrm{G}$. e. Indivíduo homozigoto TT para o gene IL-1B - 174 C>G. f. Indivíduo heterozigoto CT para o gene IL-1B - 174 C>G. 
5.6.3 Perfil do polimorfismo genético das interleucinas (IL-1 $\beta$ e IL-6) na população estudada e sua relação com a detecção dos diversos microrganismos

Os dados nas tabelas 19, 20, 21 e 22 permitem analisar a relação de risco entre a presença dos microrganismos envolvidos em infecções do trato genital, detectados nas amostras clínicas pelas duas técnicas de PCR, e os polimorfismos das citocinas. São comparados os diferentes genótipos encontrados, atribuindo como desfecho de risco os indivíduos que apresentaram o genótipo mutante, diferente dos alelos dominantes no genótipo selvagem (G para IL-6 e C para IL-1ß). Em seguida, foi observado que não houve associação significante entre os genótipos e quase todos os microrganismos, exceto para Chlamydia trachomatis em que teve relação significante com o genótipo TT (OR 19,00, 95\% IC 1,47; 245,64, p $=0,002)$.

5.6.4 Perfil genotípico das interleucinas (IL-1ß e IL-6) na população estudada e sua relação com a presença ou ausência de sinais e sintomas relatados

Os dados na Tabela 23 apresentam a análise de risco entre a presença de sinais e/ou sintomas na população estudada, e os polimorfismos das citocinas. São comparados os diferentes genótipos encontrados, atribuindo como desfecho de risco os indivíduos que apresentaram o genótipo diferente dos alelos dominantes (G para IL-6 e C para IL-1ß). Como evidenciado, os resultados não foram estatisticamente significantes para associação positiva entre os fatores. 
Tabela 19 - Perfil genotípico das interleucinas (IL-6 e IL-1ß) e sua relação com a detecção de U.urealyticum por meio da PCR convencional e PCR em tempo real, em amostras de DNA de mulheres atendidas em unidades de saúde de Vitória da Conquista - BA, 2011.

\begin{tabular}{|c|c|c|c|c|c|c|c|c|c|c|}
\hline \multirow[t]{2}{*}{ Interleucina } & $\begin{array}{l}\text { U. urealyticum } \\
\text { PCR-Positivo }\end{array}$ & $\begin{array}{l}\text { U. urealyticum } \\
\text { PCR-Negativo }\end{array}$ & \multirow{2}{*}{$\begin{array}{l}\text { Odds Ratio } \\
\text { (bruta) }\end{array}$} & \multirow[t]{2}{*}{ IC 95\% } & \multirow[t]{2}{*}{$\mathbf{p}^{*}$} & \multirow{2}{*}{$\begin{array}{l}\begin{array}{l}\text { U. urealyticum } \\
\text { qPCR-Positivo }\end{array} \\
\mathrm{n}(\%)\end{array}$} & \multirow{2}{*}{$\begin{array}{c}\begin{array}{c}\text { U. urealyticum } \\
\text { qPCR-Negativo }\end{array} \\
\mathrm{n}(\%)\end{array}$} & \multirow{2}{*}{$\begin{array}{l}\text { Odds Ratio } \\
\text { (bruta) }\end{array}$} & \multirow[t]{2}{*}{ IC 95\% } & \multirow[t]{2}{*}{$\mathbf{p}^{*}$} \\
\hline & n (\%) & n (\%) & & & & & & & & \\
\hline \multicolumn{11}{|l|}{ IL-6 } \\
\hline $\mathrm{CC}$ & $2(12,5)$ & $14(87,5)$ & 1,76 & {$[0,36 ; 8,56]$} & 0,475 & $3(18,8)$ & $13(81,2)$ & 1,16 & {$[0,31 ; 4,32]$} & 0,823 \\
\hline GG & $14(7,5)$ & $173(92,5)$ & 1 & & & $31(16,6)$ & $156(83,4)$ & 1 & & \\
\hline \multicolumn{11}{|l|}{ IL-6 } \\
\hline GC & $5(5,1)$ & $94(94,9)$ & 0,66 & {$[0,23 ; 1,88]$} & 0,431 & $16(16,2)$ & $83(83,8)$ & 0,97 & {$[0,50 ; 1,88]$} & 0,928 \\
\hline GG & $14(7,5)$ & $173(92,5)$ & 1 & & & $31(16,6)$ & $156(83,4)$ & 1 & & \\
\hline \multicolumn{11}{|l|}{ IL-1 $\beta$} \\
\hline $\mathrm{TT}$ & 0 & $6(100)$ & - & - & - & $1(16,7)$ & $5(83,3)$ & 1,00 & {$[0,11 ; 8,85]$} & 1,000 \\
\hline $\mathrm{CC}$ & $14(7,3)$ & $178(92,7)$ & & & & $32(16,7)$ & $160(83,3)$ & 1 & & \\
\hline \multicolumn{11}{|l|}{ IL-1 $\beta$} \\
\hline $\mathrm{CT}$ & $7(6,7)$ & $97(93,3)$ & 0,92 & {$[0,36 ; 2,35]$} & 0,858 & $17(16,3)$ & $87(83,7)$ & 0,98 & {$[0,51 ; 1,86]$} & 0,944 \\
\hline $\mathrm{CC}$ & $14(7,3)$ & $178(92,7)$ & 1 & & & $32(16,7)$ & $160(83,3)$ & 1 & & \\
\hline
\end{tabular}

Nota: IL-6: CC (n=16), GG (n=187), GC (n=99). IL-1ß: CC (n=192), CT (104), TT (n=6)

${ }^{*} p$ valor: significante $\leq 0,05$ 
Tabela 20 - Perfil genotípico das interleucinas (IL-6 e IL-1ß) e sua relação com a detecção de $U$. parvum por meio da PCR convencional e PCR em tempo real, em amostras de DNA de mulheres atendidas em unidades de saúde de Vitória da Conquista - BA, 2011.

\begin{tabular}{|c|c|c|c|c|c|c|c|c|c|c|}
\hline Interleucina & $\begin{array}{c}\begin{array}{c}\text { U. parvum } \\
\text { PCR-Positivo }\end{array} \\
\mathrm{N}(\%)\end{array}$ & $\begin{array}{c}\begin{array}{c}\text { U. parvum } \\
\text { PCR-Negativo }\end{array} \\
\mathrm{N}(\%)\end{array}$ & $\begin{array}{l}\text { Odds Ratio } \\
\text { (bruta) }\end{array}$ & IC 95\% & $\mathbf{p}^{*}$ & $\begin{array}{c}\begin{array}{c}\text { U. parvum } \\
\text { qPCR-Positivo }\end{array} \\
\mathrm{n}(\%)\end{array}$ & $\begin{array}{c}\begin{array}{c}\text { U. parvum } \\
\text { qPCR-Negativo }\end{array} \\
\mathrm{N}(\%)\end{array}$ & $\begin{array}{l}\text { Odds Ratio } \\
\text { (bruta) }\end{array}$ & IC 95\% & $\mathbf{p}^{*}$ \\
\hline \multicolumn{11}{|l|}{ IL-6 } \\
\hline $\mathrm{CC}$ & $10(62,5)$ & $6(37,5)$ & 1,36 & {$[0,47 ; 3,89]$} & 0,566 & $10(62,5)$ & $6(37,5)$ & 1,02 & {$[0,35 ; 2,93]$} & 0,970 \\
\hline GG & $103(55,1)$ & $84(44,9)$ & 1 & & & $116(62,0)$ & $71(38,0)$ & & & \\
\hline \multicolumn{11}{|l|}{ IL-6 } \\
\hline GC & $44(44,4)$ & $55(55,6)$ & 0,65 & {$[0,40 ; 1,06]$} & 0,087 & $57(57,6)$ & $42(42,4)$ & 0,83 & {$[0,51 ; 1,36]$} & 0,463 \\
\hline GG & $103(55,1)$ & $84(44,9)$ & 1 & & & $116(62,0)$ & $71(38,0)$ & & & \\
\hline \multicolumn{11}{|l|}{ IL-1 $\beta$} \\
\hline $\mathrm{TT}$ & $5(83,3)$ & $1(16,7)$ & 4,41 & {$[0,51 ; 38,47]$} & 0,144 & $5(83,3)$ & $1(16,7)$ & 2,93 & {$[0,34 ; 25,62]$} & 0,308 \\
\hline $\mathrm{CC}$ & $102(53,1)$ & $90(46,9)$ & 1 & & & $121(63,0)$ & $71(37,0)$ & & & \\
\hline \multicolumn{11}{|l|}{ IL-1 $\beta$} \\
\hline CT & $50(48,1)$ & $54(51,9)$ & 0,82 & {$[0,51 ; 1,32]$} & 0,407 & $57(54,8)$ & $47(45,2)$ & 0,71 & {$[0,44 ; 1,16]$} & 0,168 \\
\hline $\mathrm{CC}$ & $102(53,1)$ & $90(46,9)$ & 1 & & & $121(63,0)$ & $71(37,0)$ & & & \\
\hline
\end{tabular}

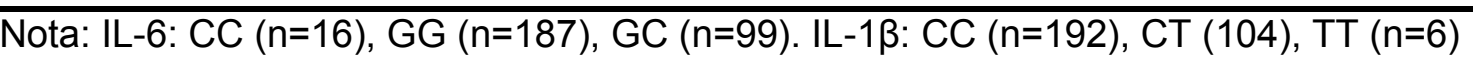

$* p$ valor: significante $\leq 0,05$ 
Tabela 21 - Perfil genotípico das interleucinas (IL-6 e IL-1ß) e sua relação com a detecção de $T$. vaginalis e N. gonorrhoeae por meio da PCR convencional em amostras de DNA de mulheres atendidas em unidades de saúde de Vitória da Conquista - BA, 2011.

\begin{tabular}{|c|c|c|c|c|c|c|c|c|c|c|}
\hline Interleucina & $\begin{array}{c}\begin{array}{c}\text { T. vaginalis } \\
\text { PCR-positivo }\end{array} \\
\mathrm{n}(\%)\end{array}$ & $\begin{array}{c}\begin{array}{c}\text { T. vaginalis } \\
\text { PCR-Negativo }\end{array} \\
\mathrm{N}(\%)\end{array}$ & $\begin{array}{l}\text { Odds Ratio } \\
\text { (bruta) }\end{array}$ & IC 95\% & $\mathbf{p}^{*}$ & $\begin{array}{c}\text { N. gonorrhoea } \\
\text { PCR-positivo }\end{array}$ & $\begin{array}{c}\begin{array}{l}\text { N. gonorrhoea } \\
\text { PCR-Negativo }\end{array} \\
\mathrm{N}(\%)\end{array}$ & $\begin{array}{l}\text { Odds Ratio } \\
\text { (bruta) }\end{array}$ & IC 95\% & $\mathbf{p}^{*}$ \\
\hline \multicolumn{11}{|l|}{ IL-6 } \\
\hline $\mathrm{CC}$ & $1(6,2)$ & $15(93,8)$ & 2,42 & {$[0,26 ; 22,13]$} & 0,418 & $2(12,5)$ & $14(87,5)$ & 0,54 & {$[0,11 ; 2,48]$} & 0,424 \\
\hline GG & $5(2,7)$ & $182(97,3)$ & 1 & & & $39(20,9)$ & $148(79,1)$ & 1 & & \\
\hline \multicolumn{11}{|l|}{ IL-6 } \\
\hline GC & $3(3,0)$ & $96(97,0)$ & 1,13 & {$[0,26 ; 4,86]$} & 0,862 & $24(24,2)$ & $75(75,8)$ & 1,21 & {$[0,68 ; 2,16]$} & 0,511 \\
\hline GG & $5(2,7)$ & $182(97,3)$ & 1 & & & $39(20,9)$ & $148(79,1)$ & 1 & & \\
\hline \multicolumn{11}{|l|}{ IL-1 $\beta$} \\
\hline TT & $0(0,0)$ & $6(100,0)$ & - & - & - & $1(16,7)$ & $5(83,3)$ & 0,67 & {$[0,07 ; 5,91]$} & 0,719 \\
\hline $\mathrm{CC}$ & $4(2,1)$ & $188(97,9)$ & & & & $44(22,9)$ & $148(77,1)$ & 1 & & \\
\hline \multicolumn{11}{|l|}{ IL-1 $\beta$} \\
\hline CT & $5(4,8)$ & $99(95,2)$ & 2,37 & {$[0,62 ; 9,03]$} & 0,193 & $20(19,2)$ & $84(80,8)$ & 0,80 & {$[0,44 ; 1,44]$} & 0,462 \\
\hline $\mathrm{CC}$ & $4(2,1)$ & $188(97,9)$ & 1 & & & $44(22,9)$ & $148(77,1)$ & 1 & & \\
\hline
\end{tabular}

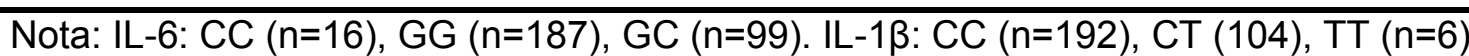

* $p$ valor: significante $\leq 0,05$ 
Tabela 22 - Perfil genotípico das interleucinas (IL-6 e IL-1ß) e sua relação com a detecção de G. vaginalis e $C$. trachomatis por meio da PCR convencional em amostras de DNA de mulheres atendidas em unidades de saúde de Vitória da Conquista - BA, 2011.

\begin{tabular}{|c|c|c|c|c|c|c|c|c|c|c|}
\hline Interleucina & $\begin{array}{c}\begin{array}{c}\text { G. vaginalis } \\
\text { PCR-positivo }\end{array} \\
\mathrm{n}(\%)\end{array}$ & $\begin{array}{c}\begin{array}{c}\text { G. vaginalis } \\
\text { PCR-Negativo }\end{array} \\
\mathbf{n}(\%)\end{array}$ & $\begin{array}{l}\text { Odds Ratio } \\
\text { (bruta) }\end{array}$ & IC 95\% & $\mathbf{p}^{*}$ & $\begin{array}{c}\text { C.trachomatis } \\
\text { PCR-positivo }\end{array}$ & $\begin{array}{c}\begin{array}{l}\text { C.trachomatis } \\
\text { PCR-Negativo }\end{array} \\
\mathrm{N}(\%)\end{array}$ & $\begin{array}{l}\text { Odds Ratio } \\
\text { (bruta) }\end{array}$ & IC 95\% & $\mathbf{p}^{*}$ \\
\hline \multicolumn{11}{|l|}{ IL-6 } \\
\hline $\mathrm{CC}$ & $7(43,8)$ & $9(56,2)$ & 1,21 & {$[0,43 ; 3,40]$} & 0,711 & $0(0,0)$ & $16(100,0)$ & -- & -- & -- \\
\hline GG & $73(39,0)$ & $114(61,0)$ & 1 & & & $2(1,1)$ & $185(98,9)$ & & & \\
\hline \multicolumn{11}{|l|}{ IL-6 } \\
\hline GC & $48(48,5)$ & $51(51,5)$ & 1,47 & {$[0,89 ; 2,40]$} & 0,124 & $3(3,0)$ & $96(97,0)$ & 2,89 & {$[0,47 ; 17,59]$} & 0,229 \\
\hline GG & $73(39,0)$ & $114(61,0)$ & 1 & & & $2(1,1)$ & $185(98,9)$ & 1 & & \\
\hline \multicolumn{11}{|l|}{ IL-1 $\beta$} \\
\hline $\mathrm{TT}$ & $4(66,7)$ & $2(33,3)$ & 2,62 & {$[0,47 ; 14,68]$} & 0,255 & $1(16,7)$ & $5(83,3)$ & 19,00 & {$[1,47 ; 245,64]$} & 0,002 \\
\hline $\mathrm{CC}$ & $83(43,2)$ & $109(56,8)$ & 1 & & & $2(1,0)$ & $190(99,0)$ & 1 & & \\
\hline \multicolumn{11}{|l|}{ IL-1 $\beta$} \\
\hline $\mathrm{CT}$ & $41(39,4)$ & $63(60,6)$ & 0,85 & {$[0,52 ; 1,38]$} & 0,526 & $2(1,9)$ & $102(98,1)$ & 1,86 & {$[0,25 ; 13,42]$} & 0,531 \\
\hline $\mathrm{CC}$ & $83(43,2)$ & $109(56,8)$ & 1 & & & $2(1,0)$ & $190(99,0)$ & 1 & & \\
\hline
\end{tabular}

Nota: IL-6: CC ( $n=16)$, GG ( $n=187)$, GC ( $n=99) ;$ IL-1ß: CC $(n=192)$, CT (104), TT ( $n=6)$

* $p$ valor: significante $\leq 0,05$ 
Tabela 23 - Perfil genotípico das interleucinas (IL-6 e IL-1ß) e sua relação com a presença de sinais e/ou sintomas clínicos reportados ou evidenciados em mulheres atendidas em unidades de saúde de Vitória da Conquista - BA, 2011.

\begin{tabular}{|c|c|c|c|c|c|}
\hline Interleucina & $\begin{array}{c}\text { Sinais e sintomas } \\
\text { Positivo }\end{array}$ & $\begin{array}{c}\text { Sinais e sintomas } \\
\text { Negativo }\end{array}$ & $\begin{array}{l}\text { Odds Ratio } \\
\text { (bruta) }\end{array}$ & IC 95\% & $\mathbf{p}^{*}$ \\
\hline & n (\%) & n (\%) & & & \\
\hline \multicolumn{6}{|l|}{ IL-6(1) } \\
\hline $\mathrm{CC}$ & $10(62,5)$ & $6(37,5)$ & 0,35 & {$[0,12 ; 1,05]$} & 0,053 \\
\hline GG & $154(82,4)$ & $33(17,6)$ & 1 & & \\
\hline \multicolumn{6}{|l|}{ IL-6(2) } \\
\hline $\mathrm{GC}$ & $72(74,2)$ & $25(25,8)$ & 0,61 & {$[0,34 ; 1,11]$} & 0,107 \\
\hline GG & $154(82,4)$ & $33(17,6)$ & 1 & & \\
\hline \multicolumn{6}{|l|}{ IL-1 $\beta(1)$} \\
\hline TT & $6(100,0)$ & $0(0,0)$ & -- & -- & -- \\
\hline $\mathrm{CC}$ & $150(78,5)$ & $41(21,5)$ & & & \\
\hline \multicolumn{6}{|l|}{ IL-1 $\beta(2)$} \\
\hline CT & $80(77,7)$ & $23(22,3)$ & 0,95 & {$[0,53 ; 1,69]$} & 0,864 \\
\hline $\mathrm{CC}$ & $150(78,5)$ & $41(21,5)$ & 1 & & \\
\hline
\end{tabular}

Nota: IL-6: CC ( $n=16)$, GG ( $n=187)$, GC ( $n=99) ;$ IL-1ß: CC ( $n=192)$, CT (104), TT (n=6).

${ }^{*} p$ valor: significante $\leq 0,05$

\subsection{Dosagem das citocinas no soro das mulheres analisadas}

5.7.1 Análise das citocinas em relação aos dados clínicos e detecção de ureaplasmas

Ao serem quantificadas as citocinas IL-1 $1 \beta$ e IL-6, no plasma sanguíneo das mulheres, não foi observada diferença estatisticamente significante entre os grupos caso e controle tanto para IL-1 $\beta(p=0,735)$ quanto para IL-6 $(p=0,735)$ (Figura 11). 
Figura 11 - Quantificação de IL-1 e IL-6 (pg/mL) no plasma sanguíneo, por meio do ELISA, nos grupos caso e controle de mulheres atendidas em unidades de saúde de Vitória da Conquista - BA, 2011.

(a)

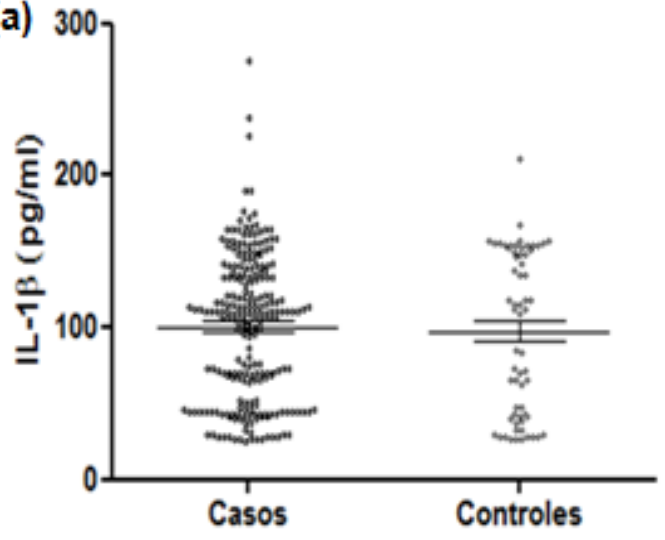

(b)

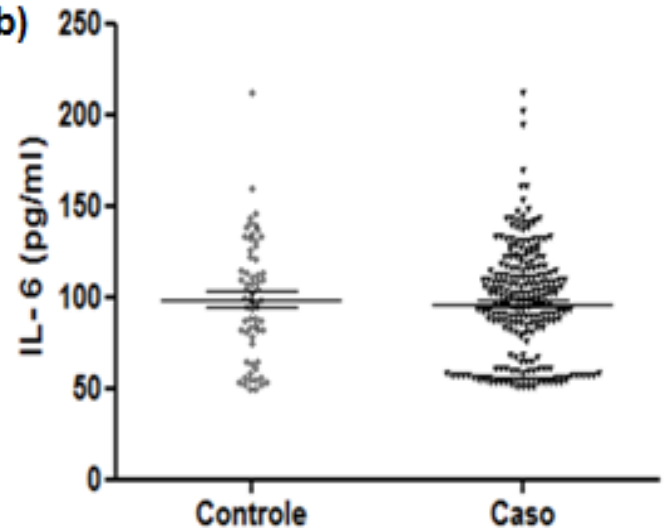

Legenda: (a) Concentração de IL-1 $\beta$ (pg/mL) no plasma sanguíneo das mulheres casos e controles (b) Concentração de IL-6 (pg/mL) no plasma sanguíneo das mulheres casos e controles. Desvio padrão e média indicados por linhas sólidas no gráfico. Análise estatística por Mann Whitney; $p<0,05$.

As Figuras 12 e 13 mostram os resultados da quantificação das citocinas entre os grupos de mulheres com ou sem infecção por ureaplasmas no trato genital. A relação entre a colonização vaginal de $U$. urealyticum e $U$. parvum e concentrações sanguíneas de IL-1 $1 \beta$ e IL-6 foram analisadas.

Não houve associação entre a presença de $U$. urealyticum $\mathrm{e}$ as concentrações de IL-1 $\beta$ e IL-6 entre as mulheres (Figuras 12a e 12b). Em contraste, a colonização por $U$. urealyticum, detectada na reação de $\mathrm{qPCR}$, foi associada ( $p=$ $0,0299)$ com maiores concentrações de IL-1 $\beta$ nas mulheres sem sinais e/ou sintomas (grupo controle), quando comparados aquelas que apresentaram sinais e/ou sintomas (grupo caso) (Figura 12c). A diferença de concentração de IL-6 entre os grupos caso e controle positivos na qPCR para $U$. urealyticum não apresentou associação significante $(p=0,5614)$ (Figura $12 d)$. 
Figura 12 - Relação entre a infecção vaginal por $U$. urealyticum, e as concentrações das citocinas IL-1 $1 \beta$ e IL-6 no plasma sanguíneo, por meio do ELISA, entre mulheres atendidas em unidades de saúde de Vitória da Conquista - BA, 2011.

(a)

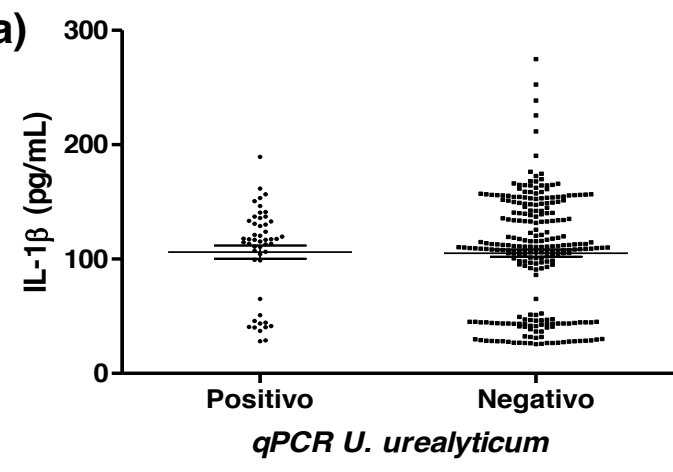

(c)

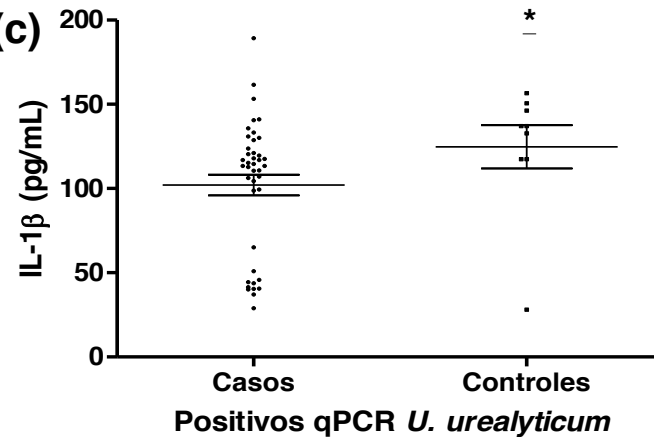

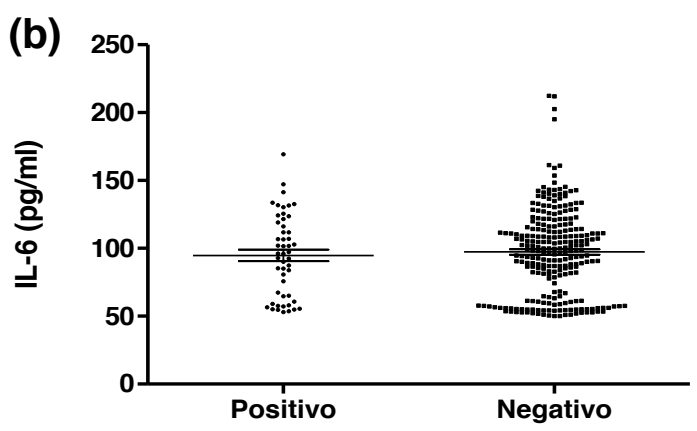

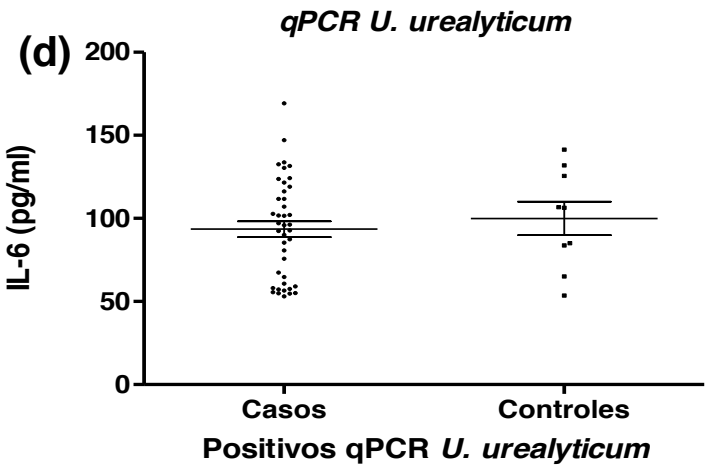

Legenda: (a) Concentração de $\mathrm{IL}-1 \beta$ ( $\mathrm{pg} / \mathrm{mL}$ ) no plasma sanguíneo das mulheres qPCR positivo e negativo para $U$. urealyticum. (b) Concentração de IL-6 $(\mathrm{pg} / \mathrm{mL})$ no plasma sanguíneo das mulheres qPCR positivo e negativo para U. urealyticum. (c) Concentração de $\mathrm{IL}-1 \beta(\mathrm{pg} / \mathrm{mL})$ no plasma sanguíneo das mulheres casos e controles positivos para $\mathrm{U}$. urealyticum na qPCR. (d) Concentração de IL-6 (pg/mL) no plasma sanguíneo das mulheres casos e controles positivos para U. urealyticum na qPCR. Desvio padrão e média indicados por linhas sólidas no gráfico. Análise estatística realizada por Mann Whitney. $p<0,05$.

Não houve diferença significativa entre a concentração de IL-1 $\beta$ no plasma sanguíneo e a colonização vaginal por U. parvum (Figura 13a). Por outro lado, encontrou-se diferença significativa entre a concentração plasmática de IL-6, onde as mulheres sem infecção por $U$. parvum apresentaram maiores níveis da citocina do que as mulheres com infecção $(p=0,0312)$ (Figura 13b). As diferenças de concentrações de IL-1 $1 \beta$ e IL-6 entre os grupos caso e controle positivos na qPCR para U. parvum não apresentaram associação estatisticamente significante (Figuras $13 c$ e 13d). 
Figura 13 - Relação entre a infecção vaginal por $U$. parvum, e as concentrações das citocinas IL-1 $\beta$ e IL-6 no plasma sanguíneo, por meio do ELISA, entre mulheres atendidas em unidades de saúde de Vitória da Conquista - BA, 2011.

(a)

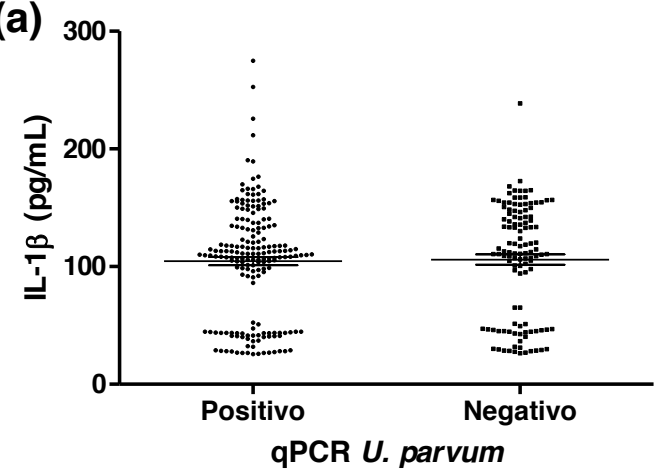

(c)

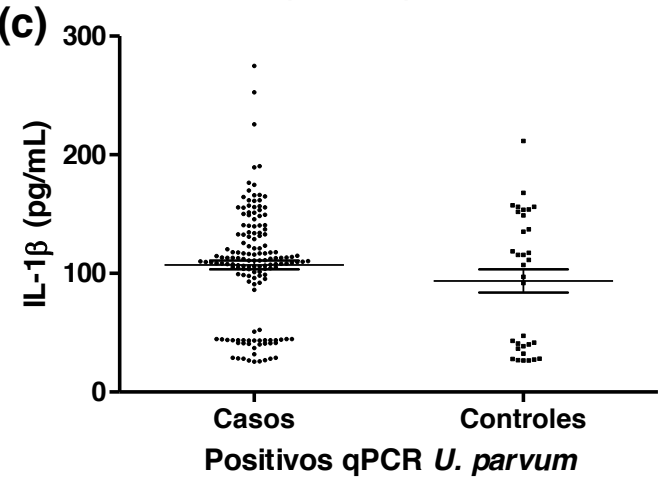

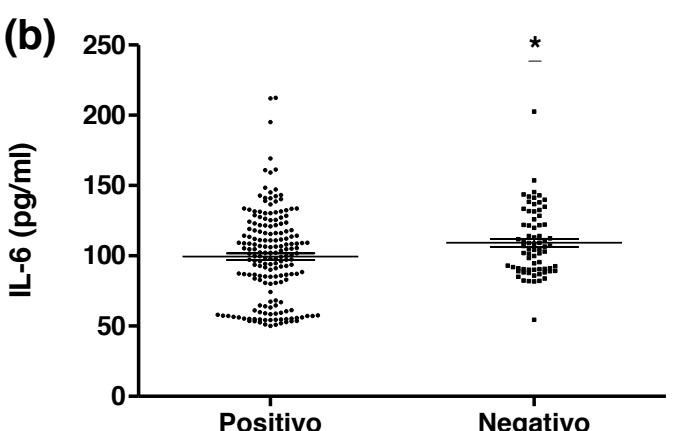

qPCR U. parvum

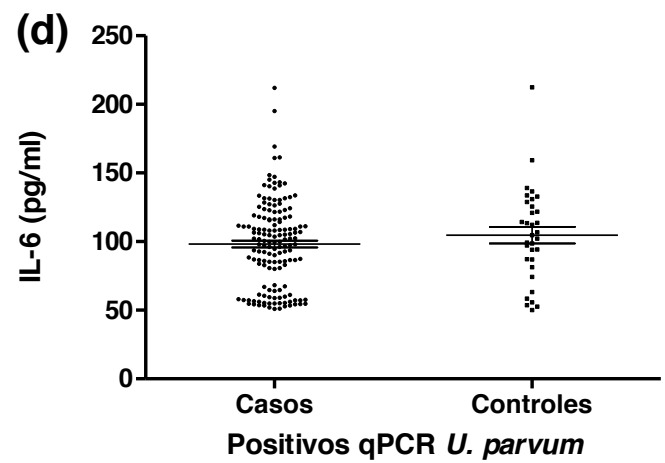

Legenda: (a) Concentração de $\mathrm{IL}-1 \beta(\mathrm{pg} / \mathrm{mL})$ no plasma sanguíneo das mulheres qPCR positivo e negativo para $U$. parvum. (b) Concentração de $\mathrm{IL}-6(\mathrm{pg} / \mathrm{mL})$ no plasma sanguíneo das mulheres qPCR positivo e negativo para U. parvum. (c) Concentração de IL-1ß $(\mathrm{pg} / \mathrm{mL})$ no plasma sanguíneo das mulheres casos e controles positivos para U. parvum na qPCR. (d) Concentração de IL-6 (pg/mL) no plasma sanguíneo das mulheres casos e controles positivos para U. parvum na qPCR. Desvio padrão e média indicados por linhas sólidas no gráfico. Análise estatística realizada por Mann Whitney. $p<0,05$.

5.7.2 Relação entre a quantificação das citocinas IL-1ß e IL-6 e a distribuição genotípica dos polimorfismos associados

A dosagem das citocinas foi comparada à distribuição dos diferentes genótipos das citocinas, e não houve diferença estatisticamente significante entre as dosagens das citocinas IL-1 $\beta$ e IL- 6 e os perfis genotípicos dos grupos de mulheres caso e controle (Figura 14). A distribuição dos genótipos para IL-1 $\beta$ não encontrou o perfil genotípico homozigoto TT entre as mulheres do grupo controle. 
Figura 14 - Quantificação de IL-1 e IL-6 no plasma sanguíneo nos grupos caso e controle e sua relação com o perfil genotípico dos polimorfismos associados às citocinas encontrados em mulheres atendidas em unidades de saúde de Vitória da Conquista - BA, 2011.
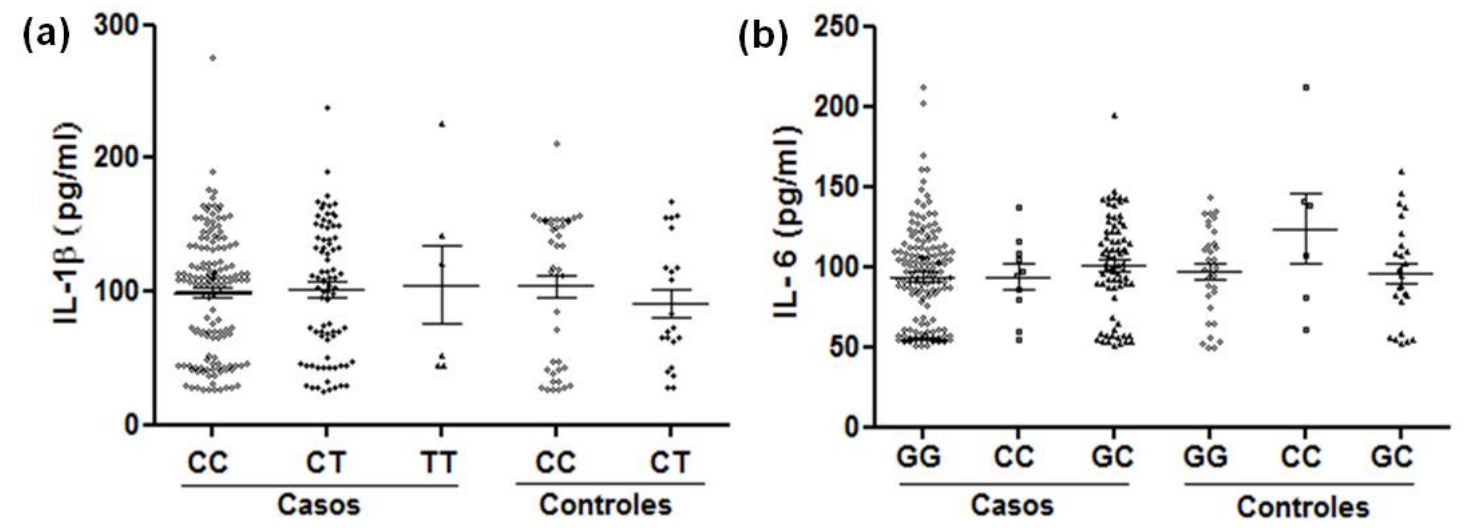

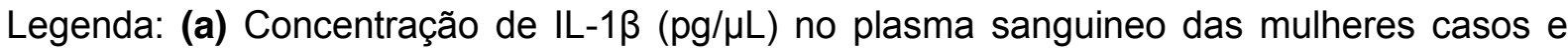
controles de acordo com o genótipo. (b) Concentração de IL-6 (pg/ $/ \mathrm{L})$ no plasma sanguineo das mulheres casos e controles de acordo com o genótipo. Desvio padrão e média indicados por linhas sólidas no gráfico. Análise estatística realizada por Mann Whitney. $p<$ 0,05 . 


\section{DISCUSSÃO}

Algumas espécies de bactérias da Classe Mollicutes são comensais do trato urogenital humano, e podem ser transmitidas por meio do contato sexual. Indivíduos colonizados podem permanecer assintomáticos, porém muitos estudos associam esses microrganismos como fatores causais de vaginose bacteriana (ROSENSTEIN et al., 1996), doença inflamatória pélvica, infertilidade, aborto, parto prematuro, dificuldade respiratória em recém-nascidos e meningite neonatal (PATEL; NYIRJESY, 2010; SCHLICHT et al., 2004; WAITES; KATZ; SCHELONKA, 2005a).

No presente estudo, Mollicutes foram encontrados em 230 (76,2\%) das 302 amostras de swab genital das mulheres participantes do estudo. Da mesma maneira, Mclver et al. (2009) relataram uma prevalência de $68,2 \%$ desses microrganismos em amostras de swab genital de mulheres australianas atendidas em clínicas de saúde sexual. A presença dos Mollicutes apresentou associação positiva com mulheres que residiam na zona rural, tinham vida sexual ativa e apresentaram mais de um parceiro sexual nos últimos três meses anteriores ao estudo. Mollicutes foram comumente detectados em adultos jovens com distúrbios cervicais ou uretrais, e foram significantemente associados com mulheres sintomáticas (com queixas de disúria e corrimento vaginal) e sem evidências da presença de outros patógenos envolvidos nas IST (SCHLICHT et al., 2004). Outros estudos mostram que a prevalência não foi significantemente associada a idade, sexo, região geográfica ou sintomas específicos (MANHART et al., 2003, 2007).

Dentre os microrganismos da Classe Mollicutes, destacam-se os patógenos humanos do gênero Ureaplasma, que estão envolvidos na patogênese de diversas doenças, como uretrite não-gonocócica e não-clamidial em homens, vaginose bacteriana, corioamnionite e parto prematuro em mulheres e displasia broncopulmonar em recém-nascidos (PATEL; NYIRJESY, 2010; WAITES; KATZ; SCHELONKA, 2005a).

No presente estudo, $U$. urealyticum foi identificado em 7,0\% (21/302) das amostras clínicas submetidas a PCR convencional. Este resultado está de acordo com o estudo de Kataoka et al. (2006), onde 8,7\% das 877 amostras de swab vaginal de mulheres grávidas, foram positivas para $U$. urealyticum. Mclver et al. (2009), encontraram U. urealyticum em $6,1 \%$ das amostras cervicais de mulheres australianas sexualmente ativas. Outros estudos descreveram prevalências maiores 
para infecções por U. urealyticum. Kim et al. (2011) em estudo realizado na Coréia, observaram que entre indivíduos assintomáticos com uretrite e/ou cervicite, a prevalência de infecção por $U$. urealyticum foi de 22,1\%. Da mesma maneira, outro estudo realizado na cidade de Turim na Itália, utilizando PCR em amostras endocervicais de mulheres não grávidas, U. urealyticum foi detectado em $16,9 \%$ dos casos (TIBALDI et al., 2009). Na Índia, amostras de pacientes com infecções no trato genital foram submetidas ao PCR para detecção do gene da urease, e 39\% dos sintomáticos apresentaram o microrganismo (GUPTA et al., 2008).

Em relação à técnica de qPCR, observou-se uma maior detecção de $U$. urealyticum, e um total de 16,6\% (50/302) das mulheres foram positivas. Dados similares, foram apresentados por Cunningham et al. (2013) que analisaram amostras do trato geniturinário, descrevendo uma prevalência de $12 \%$ para $U$. urealyticum. Berle et al. (2012) em estudo realizado na Rússia analisaram por qPCR amostras de urina de 1729 indivíduos, encontrando prevalência de $12,8 \%$ de $U$. urealyticum.

No presente estudo, a detecção de U. urealyticum por PCR convencional mostrou associação positiva com mulheres que residem na região rural do município de Vitória da Conquista. No entanto, em relação às análises pela qPCR, as amostras positivas foram associadas ao fato de residirem na região rural e também relatarem mais de um parceiro sexual nos três meses anteriores a coleta do estudo. Além disso, $82 \%$ das amostras positivas para $U$. urealyticum eram de sintomáticos. Altas taxas de detecção de ureaplasmas genitais foram encontradas em indivíduos assintomáticos e isto implica que, $U$. urealyticum é susceptível de ser encontrado no trato genital e podendo, por vezes, tornar-se patogênico (TAKAHASHI et al., 2006).

No estudo de Tibaldi et al. (2009), U. urealyticum foi significativamente associado às mulheres entre 14 e 25 anos, ausência de parceiro constante, histórico de aborto, uso de DIU, mais de um parceiro sexual nos últimos seis meses e mais do que dois parceiros sexuais na vida. Outro estudo recente realizado no México associou a frequência de $U$. urealyticum em amostras cervico-vaginais com quadros de vaginite (HERNÁNDEZ-MARTÍNEZ et al., 2013). A infecção por U. urealyticum também foi associada aos sintomas clínicos de corrimento vaginal e irritação vulvar entre pacientes atendidas em clínicas de DST na Polônia, e em 8,1\% das mulheres, o curso da infecção era assintomático (ZDRODWSKA-STEFANOW, 2006). 
A espécie $U$. parvum é mais comum que $U$. urealyticum como colonizadora do trato urogenital de homens e mulheres e do trato respiratório de neonatos (PARALANOV et al., 2012). No presente estudo, U. parvum foi detectado em 52,3\% (158/302) das amostras vaginais. Este dado é consistente com dados da literatura, que monstraram maior prevalência de $U$. parvum em amostras do trato urogenital em relação a U. urealyticum (BAO et al., 2010; DE FRANCESCO et al., 2009; GUPTA et al., 2008; HUMBURG et al., 2012). Yamazaki et al. (2012), em estudo realizado no Japão com mulheres na primeira consulta pré-natal, observaram por PCR a prevalência de $41,7 \%$ para $U$. parvum e $8,9 \%$ para $U$. urealyticum. Em concordância, Mclver et al. (2009) também verificaram que o $U$. parvum foi o microrganismo mais comum isolado de amostras de swab cervical de mulheres sexualmente ativas.

Neste estudo, as análises realizadas pela qPCR demonstraram que prevalência de infecção por U. parvum foi maior, atingindo 83,4\% (252/302) das mulheres. Cunningham et al. (2013) encontraram a prevalência de $41 \%$ para $U$. parvum em amostras de urina, utilizando a mesma técnica. Estudos anteriores utilizando o ensaio de qPCR também encontraram $U$. parvum com maior frequência de detecção que $U$. urealyticum (MCKECHNIE et al., 2011; TANG et al., 2011; VANCUTSEM et al., 2011).

Os resultados da PCR convencional e qPCR demonstraram a associação de $U$. parvum com mulheres de vida sexual ativa e que apresentaram mais de um parceiro sexual nos três meses anteriores ao estudo. Outros estudos mencionam associação com DIP (TAYLOR-ROBINSON et al., 2012), trabalho de parto prematuro (SUNG et al., 2010) e displasia broncopulmonar em neonatos (ROSE; VISCARDI, 2010). Reyes et al. (2009), com modelo animal de infecção do trato urinário, mostraram que as complicações associadas com a infecção por $U$. parvum são primariamente dependentes de fatores específicos do hospedeiro. Segundo Jones, Chaban e May (2013) os estudos de associação da infecção por U. parvum e sinais clínicos foram inconsistentes.

Entre as amostras vaginais com U. parvum detectadas por PCR convencional, o sorotipos 6 e 3/14 foram os mais freqüentes, com 40,8\% e $39,5 \%$, respectivamente, sendo o sorotipo 1 o menos frequente (23,6\%). Por outro lado, Kong et al. (2000), descreveram uma maior frequencia dos sorotipos 3/14 e 1 do que do sorotipo 6, em amostras de swab vaginal de mulheres grávidas e mulheres atendidas em clínicas de doenças sexualmente transmissíveis. De Francesco et al. 
(2009), em estudo realizado na Itália a partir de amostras de swab vaginal, uretral e endocervical de mulheres, mostraram que os sorotipos 1 e 3/14 foram os mais frequentes, enquanto o sorotipo 6 apresentou-se menos prevalente. Segundo Robinson et al. (2013) o sorotipo 3 foi o mais comum isolado de amostras de homens e mulheres. Estas variações de detecção, observadas nos diferentes estudo, podem ter sido devido as diferenças de localização geográfica, tipo de amostras coletadas e sintomatologia observadas.

As características clínicas associadas com os diferentes sorotipos de $U$. parvum diferiram no presente estudo. O sorotipo 1 foi estatisticamente associado às mulheres que residiam na região rural e ao sintoma disúria, enquanto, o sorotipo 3/14 mostrou associação com mais de um parceiro sexual nos últimos três meses e corrimento vaginal. Além disso, não foram encontradas associações entre as variáveis sociodemográfica com o sorotipo 6. Outro estudo encontrou associações entre o $U$. parvum sorotipo 3/14 e mulheres sintomáticas, sendo o sorotipo 6 associado com mulheres assintomáticas (DE FRANCESCO et al., 2009). Knox et al. (2003) demonstraram que o $U$. parvum sorotipo 6 foi significantemente associado com o parto prematuro.

Uma amostra de swab genital positiva para $U$. parvum não foi atribuída a quaisquer dos sorotipos conhecidos, por meio de PCR. Para determinar o possível motivo da amostra ser negativa em todos os testes específicos para sorotipos, Xião et al. (2011) propõem realizar o sequenciamento do isolado, o que permitiria relacioná-lo mais estreitamente com algum sorotipo específico. Embora ureaplasmas sejam caracterizados por apresentarem genoma mínimo, e evolução degenerativa, o que normalmente não é favorável para a aquisição de DNA ativo, evidências mostram que transferência horizontal de genes podem ocorrer tanto entre espécies distintas de micoplasmas como também, entre mesma espécie. Diante disso, a amostra não-tipável pode representar novos sorotipos ainda não caracterizados. 0 sistema de classificação em 14 sorotipos foi previsto para ser expandido desde o momento em que foi estabelecido, tendo, outros estudos assim como este, relatado certo número de isolados não-tipáveis (XIAO et al., 2010; ZIMMERMAN et al., 2011). Foram propostos possíveis mecanismos de recombinação responsáveis pela variação antigênica e consequente surgimento de sorotipos híbridos (CZURDA et al., 2010; ZIMMERMAN; ROSENGARTEN; SPERGSER, 2013). 
No presente estudo, um total de 3,0\% (9/302) das mulheres foram positivas para $T$. vaginalis, não sendo encontrada associação entre este microrganismo e sintomas específicos. Van Der Pol et al. (2005), em estudo realizado com mulheres adolescentes, encontraram maior prevalência de $T$. vaginalis $(23,2 \%)$ na cidade de Indiana. Segundo Mitchell e Hussey (2010), metade das mulheres infectadas por $T$. vaginalis são assintomáticas e alguns sintomas comuns da infecção incluem corrimento vaginal, prurido, odor, disúria e vulvovaginites. Outro estudo realizado no Quênia descreveu associação entre a infecção por $T$. vaginalis e aumento do risco de infecção pelo HIV (QUINN, 1996; MCCLELLAND et al., 2007). Entre as mulheres africanas, a tricomoníase foi associada à primeira relação sexual com menos de 20 anos, histórico de IST prévia e presença de corrimento vaginal (SWYGARD et al., 2003). Entretanto, nos Estados Unidos, um estudo revelou a prevalência de 3,1\% nas mulheres entre 14 e 49 anos, com taxas mais elevadas em mulheres negras com idade entre 40 e 49 anos (SUTTON et al., 2007). Gaydos et al. (2011) encontraram associações significativas entre mulheres negras, que tiveram de dois a 15 ou mais de 16 parceiros no ano anterior ao estudo, apresentavam relações bissexuais, e nem sempre usavam preservativo.

N. gonorrhoeae foi identificada, no presente estudo, em 21,5\% (65/302) das mulheres e foi estatisticamente associado com o sintoma sinusiorragia. Estudo realizado na China apresentou prevalência inferior de infecção por $N$. gonorrhoeae, de 5,91\% entre mulheres profissionais do sexo, tendo, ainda associado a presença de $N$. gonorrhoeae com infecções por $C$. trachomatis (CHEN et al., 2013). Frequências menores também foram encontradas em amostras endocervicais por Crotchfelt et al. (1997) em 7,8\% das mulheres analisadas e por Livengood e Wrenn (2001) em 4,4\%. Da mesma maneira, Usanga et al. (2010) relataram a prevalência de $N$. gonorrhoeae de 5,2\% entre as mulheres grávidas, em Calabar, Nigéria.

Outro microrganismo de importância ginecológica, também investigado no presente estudo foi $G$. vaginalis, relacionada com a etiologia da VB (KLEBANOFF et al., 2004). Este microrganismo foi detectado em 42,4\% (128/302) das amostras e associadas estatisticamente com mulheres em faixa etária menor de 25 anos e com primeira relação sexual com até 15 anos de idade. No estudo de Alli et al. (2011), a prevalência para $G$. vaginalis foi de $25 \%$ entre mulheres que apresentaram distúrbios vaginais, e para Fethers et al. (2012) a presença de G. vaginalis foi comum em mulheres virgens, no entanto, houve um aumento da prevalência de 
acordo com o número de parceiros sexuais. Murta et al. (2000) reportaram a prevalência de 23,6\% para G. vaginalis entre mulheres com Papiloma Vírus Humano (HPV) no Brasil. Por outro lado, em outro estudo realizado na Nigéria, encontrou prevalência maior $(67,6 \%)$ de $G$. vaginalis entre mulheres infectadas pelo HIV (OYEWOLE et al., 2010).

C. trachomatis foi encontrada em 1,5\% (5/302) das mulheres participantes do estudo e não foi encontrada associação com as variáveis clínicas e epidemiológicas. Alguns estudos estimam que a prevalência pode ser de $3 \%$ a $5 \%$ entre mulheres jovens australianas em amostras comunitárias (HOCKING et al., 2006; KONG et al., 2009). Walker et al. (2011) encontraram associação entre clamídia e mulheres jovens e o aumento do número de parceiros sexuais. No Brasil, estudos tem demonstrado a prevalência de infecções por $C$. trachomatis varia de 5 a 19,6\% entre jovens sexualmente ativas que frequentam clínica ginecológicas (MIRANDA et al., 2004; GUIMARÃES et al., 2009). A frequência de $C$. trachomatis em mulheres saudáveis foi de $22,9 \%$ na Inglaterra (SCOTT et al., 2007), 3,9\% em Baltimore nos Estados Unidos (EGGLESTON et al., 2011) e 14,3\% na cidade Sapporo no Japão (YAMAZAKI et al., 2012).

Entre as 50 mulheres com positividade para $U$. urealyticum, quatro $(8,0 \%)$ apresentaram co-infecção com $T$. vaginalis, nove (18,0\%) com N. gonorrhoeae, 25 $(50,0 \%)$ com $G$. vaginalis e uma $(2,0 \%)$ com $C$. trachomatis. Outros estudos também apontaram para a existência de co-infecções entre estes microrganismos e ureaplasmas genitais. Njunda et al. (2011) encontraram em amostras de mulheres sexualmente ativas positivas para $U$. urealyticum, co-infecção com $T$. vaginalis em $3,1 \%$ dos casos, e com G. vaginalis em 33,8\%. No entanto, Diaz et al. (2010) não encontraram associação entre $T$. vaginalis e $U$. urealyticum em amostras de mulheres com sintomas de vaginite. Os estudos de Berle et al. (2012) na Rússia, Kim et al. (2011) na Koréia e Denks et al. (2007) na Estônia, mostraram associação significante entre indivíduos infectados por $C$. trachomatis e a prevalência de $U$. urealyticum.

Entre as 183 mulheres positivas para U. parvum, no presente estudo, em nove (4,9\%) encontrou-se co-infecção com T. vaginalis, 40 (21,9\%) com $N$. gonorrhoeae, $82(44,8 \%)$ com G. vaginalis e 4 (2,2\%) com C. trachomatis. O estudo de Bradshaw et al. (2006) mostrou associação positiva entre infecções por $G$. vaginalis e U. parvum. Da mesma maneira, Haggerty et al. (2009) observaram que 
G. vaginalis foi isolada mais frequentemente do endométrio de mulheres positivas para U. parvum. Yamazaki et al. (2012) também relataram co-infecção entre $U$. parvum e $C$. trachomatis entre mulheres saudáveis atendidas em consulta pré-natal, no Japão. Também existem relatos da associação entre $U$. parvum e $C$. trachomatis em amostras de homens com uretrite não-gonocócica (MAEDA et al., 2004), mas essa associação não foi encontrada no estudo de Takahashi et al. (2006) com amostras de urina de homens assintomáticos.

Embora muito tenha sido descrito sobre as características microbianas que facilitam a colonização de um hospedeiro, há na atualidade o questionamento sobre como a colonização microbiana é afetada pela variabilidade da resposta do hospedeiro aos microrganismos (LAINE; LOOS; CRIELAARD, 2010). Os fatores genéticos podem ser responsáveis pelas variações individuais na resposta imune do hospedeiro a infecções. Este conceito constitui a base para compreensão da infectogenômica, que estuda as relações entre fatores genéticos do hospedeiro e a colonização microbiana (KELLAM; WEISS, 2006; NIBALI et al., 2010).

A partir dessa premissa, estudos que avaliam polimorfismos de genes associados com respostas imunes e a relação entre alelos específicos e susceptibilidade à doença tem sido realizados (JEREMIAS et al.,1999). Sendo assim, o presente estudo avaliou o polimorfismo c-174G >C no gene IL-6 e c- + 3954 $\mathrm{C}>\mathrm{T} \mathrm{n}$ gene IL-1 $\beta$ com a detecção vaginal de espécies de ureaplasma em mulheres sexualmente ativas.

A citocina pró-inflamatória IL-6 está envolvida na regulação da imunidade inata e vários estudos têm apontado que o trabalho de parto prematuro está associado ao aumento da concentração de IL-6 no soro, secreções cérvico-vaginais maternas e no líquido amniótico (ROMERO et al., 1990; RIZZO et al., 1998). O polimorfismo -174 no gene IL-6 é associado com a susceptibilidade a doenças inflamatórias agudas e crônicas, como diabetes mellitus (VOZAROVA et al., 2003), aterosclerose (BURZOTTA et al., 2001), doença de Alzheimer (FALTRACO et al., 2003) e doença periodontal (SHAO et al., 2009). A distribuição dos genótipos para IL-6, neste estudo, revelou que $61,9 \%$ das mulheres foram homozigotas para o alelo G, 32,8\% heterozigotas e 5,3\% homozigotas para o alelo C. Não houve diferença estatisticamente significante na distribuição genotípica e quantificação de IL-6 entre mulheres com $U$. urealyticum ou $U$. parvum. O mesmo ocorreu nos grupos caso e controle. Esses resultados, estão de acordo com Weissenbacher et al. (2010) que 
também não encontraram diferença nas concentrações de IL-6 entre os grupos de mulheres com e sem VB.

Por outro lado, o estudo de Goepfert et al. (2005) encontraram associação do polimorfismo no gene IL-6 com o diagnóstico de VB, onde as mulheres grávidas que apresentaram VB eram, com mais frequência, portadoras do genótipo heterozigoto GC. Outro estudo mostrou que o alelo C está associado a níveis significantemente inferiores de expressão de IL-6, e adultos com o genótipo CC têm menores concentrações plasmáticas de IL-6, comparando com adultos com genótipos GC ou GG (FISHMAN et al., 1998).

Em relação ao genótipo de IL-1 $\beta$ foi observada predominância de homozigoto para o alelo C $(63,6 \%)$, seguido do heterozigoto $(34,4 \%)$ e homozigoto para alelo $\mathrm{T}$ (2,0\%). Esses dados estão de acordo com o estudo de Cauci et al. (2007), no qual o genótipo CC foi o mais frequente $(62,9 \%)$, seguido do CT $(31,6 \%)$ e TT $(5,4 \%)$ em amostras vaginais de mulheres italianas, e ainda encontraram associação com o aumento do risco para VB e mulheres portadoras do genótipo homozigotos TT. Além disso, o genótipo TT tem sido associado com diversas doenças, como periodontite, artrite reumatóide e doença de Alzheimer (LICASTRO et al., 2004; LOPEZ; JARA; VALENZUELA, 2005; PAWLIK et al., 2005). Oittinen et al. (2005) demonstraram associação entre VB e doenças periodontais, que estão relacionadas com o mesmo polimorfismo.

De acordo alguns autores, o polimorfismo c- + $3954 \mathrm{C}>\mathrm{T} \mathrm{n}$ gene IL-1 $\beta$, contribui para o aumento a produção da citocina IL-1 $\beta$ (HERNANDEZ-GUERRERO et al, 2003; HOLLEGAARD; BIDWELL, 2006; KAARTHIKEYAN et al, 2009). No entanto, os resultados deste estudo não confirmam o aumento "in vivo" da produção de IL-1 $\beta$ relacionada com o alelo $\mathrm{T}$. Isso pode ser decorrente do pequeno número amostral de mulheres com o genótipo TT, o que não permitiu a significância estatística. Cauci et al. 2003 descreveram que o polimorfismo +3954 no gene IL-1 $\beta$ limitaria a amplificação dos sinais pró-inflamatórios de IL-1ß. Isso porque os autores não encontraram aumento do número de neutrófilos vaginais em mulheres positivas para VB, em comparação com mulheres saudáveis, o que explicaria o fato da VB não ser considerada normalmente uma condição inflamatória.

A microbiota normal com predomínio de espécies de lactobacilos na mucosa vaginal é considerada um conjunto sadio na mulher adulta. Este equilíbrio da microbiota vaginal é mantido por interações com os produtos do metabolismo 
microbiano, o estado hormonal e a resposta imune da mulher. No entanto, pouco se sabe sobre a dinâmica da comunidade microbiana vaginal e como este equilíbrio pode ser alterado diante dos hábitos da mulher, nível socioeconômico, ciclo mestrual, práticas de higiene, comportamento sexual, uso de lubrificantes e de medicamentos. Por isso, um maior conhecimento da relação entre hospedeiro e a comunidade bacteriana indígena, e do desequilíbrio da microbiota que pode desencadear sintomas associados com infecção genital com agentes patogênicos, pode levar ao desenvolvimento de estratégias de promoção da saúde.

Persistem ainda muitas dúvidas sobre a patogenicidade do Ureaplasma no trato urogenital feminino. Observou-se no presente estudo alta prevalência de infecção entre as mulheres da população em geral, além de associação com as mulheres residentes na região rural, e sinais e/ou sintomas de infecção genital. Os resultados apresentados permitem, dentro de suas limitações, fornecer dados importantes. A compreensão da realidade dos diversos aspectos clínicodemográficos que envolvem as IST na região de estudo, permitem orientar a prevenção e tratamento destas doenças pela Secretaria de Saúde do Município. Além disso, os dados obtidos no presente estudo, servem como base para outros pesquisadores realizarem novos estudos que poderão ajudar na redução de despesas com cuidados com a saúde reprodutiva pelo Sistema Único de Saúde. 


\section{CONCLUSÕES}

- A infecção por $U$. urealyticum, foi associada significativamente com a região rural de residência e com o número de parceiros sexuais nos últimos três meses.

- A infecção por U. parvum foi associada a mulheres com vida sexual ativa, ao número de parceiros sexuais nos últimos três meses.

- U. parvum sorotipo 1 apresentou associação com região rural de residência e ao sintoma disúria, o sorotipo 3/14 com o número de parceiros nos últimos três meses e com a presença de corrimento vaginal. $O$ sorotipo 6 não apresentou associação com as variáveis de saúde sexual das mulheres.

- A média da dosagem de U. urealyticum por qPCR nas amostras de swab vaginal foi maior entre as mulheres do grupo controle.

- Não houve diferença estatisticamente significante entre a média da quantificação de U. parvum nos grupos caso e controle.

- O polimorfismo $-174 \mathrm{G}>\mathrm{C}$ da IL-6 foi detectado na frequência de $61,9 \%$ para GG, $32,8 \%$ para GC e $5,3 \%$ para CC.

- O polimorfismo $+3954 \mathrm{C}>\mathrm{T}$ da IL-1 $\beta$ foi detectado na frequência de $63,6 \%$ para CC, $34,4 \%$ para CT e $2,0 \%$ para TT.

- Não foi observada associação significante entre os genótipos dos polimorfismos de IL-6 e IL-1 $\beta$ e os níveis das citocinas no plasma sanguíneo.

- Não houve diferença entre a média da dosagem de IL-6 e IL-1 $1 \beta$ no plasma sanguíneo das mulheres do grupo caso e controle.

- A concentração média de IL-6 foi maior entre as mulheres que não apresentaram infecção por U. parvum. 
- $\quad$ genótipo TT de IL-1ß foi apresentou associação significante com infecção por Chlamydia trachomatis. 


\section{REFERÊNCIAS*}

AGRAWAL, A. A.; KAPLEY, A.; YELTIWAR, R. K.; PUROHIT, H. J. Assessment of single nucleotide polymorphism at IL-1A+4845 and IL-1B+3954 as genetic susceptibility test for chronic periodontitis in maharashtrian ethnicity. J. Periodontol., v. 77, n. 9, p. 1515-1521, 2006.

ALLI, J. A. O.; OKONKO,I. O.; ODU,N. N.; KOLADE, A. F. Detection and Prevalence of Genital Pathogens among Attendees of Sti Clinic of a Tertiary Care Hospital in Ibadan, Southwestern Nigeria. World Journal of Medical Sciences, v. 6, n. 3, p. 152-161, 2011.

ANDREEV, J.; BOROVSKY, Z.; ROSENSHINE, I.; ROTTEM, S. Invasion of HeLa cells by Mycoplasma penetrans and induction of tyrosine phosphorylation of a 145 kda host cell protein. FEMS Microbiol. Lett., v. 132, p. 189-194, 1995.

ARAÚJO, R. S.; GUIMARÃES, E. M.; ALVES, M. F.; SAKURAI, E.; DOMINGOS, L. T.; FIORAVANTE, F. C.; MACHADO, A. C. Prevalence and risk factors for Chlamydia trachomatis infection in adolescent females and young women in central Brazil. Eur. J. Clin. Microbiol. Infect. Dis., v. 25, p. 397-400, 2006.

BAO, T.; CHEN, R.; ZHANG, J.; LI, D.; GUO, Y.; LIANG, P.; YAN, Z. Simultaneous detection of Ureaplasma parvum, Ureaplasma urealyticum, Mycoplasma genitalium and Mycoplasma hominis by fluorescence polarization. Journal of Biotechnology, v. 150, n. 1, p. 41-43, 2010.

BARRETT, S.; TAYLOR, C. A review on pelvic inflammatory disease. Int. J. STD AIDS., v. 16, p. 715-720, 2005.

BASEMAN, J. B.; TULLY, J. G. Mycoplasmas: sophisticated, reemerging, and burdened by their notoriety. Emerg. Infect. Dis., v. 3, p. 21-32, 1997.

BELL, C.; HOUGH, E.; SMITH, A.; GREENE, L. Targeted screening for Trichomonas vaginalis in women, a pH-based approach. Int. J. STD AIDS., v. 18, n. 6, p. 402-403, 2007.

BERGEY'S. Manual of determinative bacteriology. Michigan: Michigan State University, 2001. Disponível em: <http://www.cme.msu.edu/bergeys>. Acesso em: 14 Mar. 2005.

BERLE, L. M.; FIRSOVA, N.; KALASHNIK, A.; PROTASOVA, V. M.; PONOMAREVA, Z. V.; GUBERNICKAYA, S. V.; KUDRINA, T. I.; HAAHEIN, H.; HJELMEVOLL, S. O.; SKOGEN, V. Chlamydia trachomatis, Mycoplasma genitalium and Ureaplasma urealyticum in clinical and non-clinical settings, Arkhangelsk Oblast, Rússia. International Journal of STD \& AIDS, v. 23, p. 781784, 2012. 
BLANCHARD, A. Ureaplasma urealyticum urease genes: use of a UGA tryptophan codon. Mol. Microbiol., v. 4, p. 669-676, 1990.

BORREGAARD, N. Neutrophils, from marrow to microbes. Immunity, v. 33, p. 657-670, 2010.

BRADSHAW, C. S.; TABRIZI, S. N.; READ, T. R. H.; GARLAND, S. M.; HOPKINS, C. A.; MOSS, L. M.; FAIRLEY, C. K. Etiologies of Nongonococcal Urethritis: Bacteria, Viruses, and the Association with Orogenital Exposure. The Journal of Infectious Diseases, v. 193, p. 336-345, 2006.

BRASIL. Ministério da Saúde. Política Nacional de Atenção Integral à Saúde da Mulher: Princípios e Diretrizes / Ministério da Saúde, Secretaria de Atenção à Saúde, Departamento de Ações Programáticas Estratégicas. 1 ed. Brasília, $2011 b$.

BRASIL. Ministério da Saúde. Secretaria de Vigilância em Saúde, Programa Nacional de DST e Aids. Manual de Controle das Doenças Sexualmente Transmissíveis. Brasília, 2006.

BRASIL. Ministério da Saúde. Secretaria de Vigilância em Saúde. Departamento de DST, Aids e hepatites Virais. Pesquisa de conhecimentos, atitude e práticas na população brasileira. Brasília, 2011a.

BRASIL. Ministério da Saúde. Secretaria de Vigilância em Saúde. Programa Nacional de DST e AIDS. Prevalências relativas de Doenças Sexualmente Transmissíveis (DST) em populações selecionadas de seis capitais Brasileiras. Brasília, 2008. 224p.

BRASIL. Ministério da Saúde. Secretaria de Vigilância em Saúde. Plano Estratégico, Programa Nacional de DST e Aids. Brasília, 2005.

BROTMAN, R. M.; BRADFORD, L. L.; CONRAD, M.; GAJER, P.; AULT, K.; PERALTA, L.; FORNEY, L. J.; CARLTON, J. M.; ABDO, Z.; RAVEL, J. Association Between Trichomonas vaginalis and Vaginal Bacterial Community Composition Among Reproductive-Age Women. Sexually Transmitted Diseases, v. 39, n. 10, 2012.

BRUNHAM, R. C.; REY-LADINO, J. Immunology of Chlamydia Infection: Implications for a Chlamydia trachomatis Vaccine. Nature Reviews/Immunology, v.5, p.149-161, 2005.

BURZOTTA, F.; IACOVIELLO, L.; DI CASTELNUOVO, A.; GLIECA, F.; LUCIANI, N.; ZAMPARELLI, R.; SCHIAVELLO, R.; DONATI, M. B.; MASERI, A.; POSSATI, G.; ANDREOTTI, F. Relation of the $-174 \mathrm{G} / \mathrm{C}$ polymorphism of interleukin-6 to interleukin-6 plasma levels and to length of hospitalization after surgical coronary revascularization. Am. J. Cardiol., v. 88, p. 1125-1128, 2001. 
BUSSOLO, F.; BARATTO, T.; BERTOLONI, G.; GROSSATO, A. Survival of genital mycoplasma on various bacteriological swabs and transport media. Boll. Ist. Sieroter. Milan., v. 60, n. 1, p. 31-40, 1981.

CAO, X.; WANG, Y.; HU, X.; QING, H.; WANG, H. Real-time TaqMan polymerase chain reaction assays for quantitative detection and differentiation of Ureaplasma urealyticum and Ureaplasma parvum. Diagnostic Microbiology and Infectious Disease, v. 57, p. 373-378, 2007.

CARSON, J. L.; HU, P. C.; COLLIER, A. M. Cell structural and functional elements. In: MANILOFF J.; MCELHANEY, R. N.; FINCH L. R.; BASEMAN J. B. (Ed.). Mycoplasmas: molecular biology and pathogenesis. Washington: American Society for Microbiology, 1992. p. 63-72.

CATLIN, B. W. Gardnerella vaginalis: characterisitics, clinical considerations, and controversies. Clin. Microbiol. Rev., v. 5, p. 213-237, 1992.

CAUCI, S.; GUASCHINO, S.; DE ALOYSIO, D.; DRIUSSI, S.; DE SANTO, D.; PENACCHIONI, P.; QUADRIFOGLIO, F. Interrelationships of interleukin-8 with interleukin- $1 ß$ and neutrophils in vaginal fluid of healthy and bacterial vaginosis positive women. Mol. Hum. Reprod., v. 9, p. 53-58, 2003.

CAUCI, S.; SANTOLO, M.; CASABELLATA, G.; RYCKMAN, K.; WILLIAMS, S. M.; GUASCHINO, S. Association of interleukin-1b and interleukin-1 receptor antagonist polymorphisms with bacterial vaginosis in non-pregnant Italian women. Mol. Hum. Reproduc., v. 13, n. 4, p. 243-250, 2007.

CHEN, X.; YIN, Y.; LIANG, G.; WANG, Q.; JIANG, N.; LIU, Q.; FU, G.; YANG, B.; ZHOU, Y.; SHI, M.; WANG, B. The prevalences of Neisseria gonorrhoeae and Chlamydia trachomatis infections among female sex workers in China. BMC Public Health, v. 13, p. 121, 2013.

CHERNOV, V. M.; VOLKOVA, E. N.; CHERNOVA, O. A. Clastogenic effect of mycoplasma on human chromosomes. Dokl. Akad. Nauk., v. 344, n. 1, p. $130-$ 132, 1995.

CHISHOLM, S. A.; UNEMO, M.; QUAYE, N.; JOHANSSON, E.; COLE, M. J.; ISON, C. A.; VAN DE LAAR, M. J. Molecular epidemiological typing within the European Gonococcal Antimicrobial Resistance Surveillance Programme reveals predominance of a multidrug-resistant clone. Euro. Surveill., v. 18, n. 3, 2013.

COHEN, M. S. Sexually transmitted diseases enhance HIV transmission: no longer a hypothesis. The Lancet, v. 351, p. 5-7, 1998.

COHEN, M. S.; CANNON, J. G. Human experimentation with Neisseria gonorrhoeae: progress and goals. J. Infect. Dis., v. 179, n. 2, p. 375-379, 1999.

CORDOVA, C. M.; CUNHA, R. A. Detecção de Mycoplasma genitalium, M. fermentans e $M$. penetrans em pacientes com sintomas de uretrite e em 
indivíduos infectados pelo HIV-1 no Brasil. J. Bras. Pat. Med. Lab., v. 38, n. 2, p. 111-118, 2002.

CROTCHFELT, K. A.; WELSH, L. E.; DEBONVILLE, D.; ROSENSTRAUS, M.; QUINN, T. C. Detection of Neisseria gonorrhoeae and Chlamydia trachomatis in Genitourinary Specimens from Men and Women by a Coamplification PCR Assay. Journal of Clinical Microbiology, v. 35, n. 6, p. 1536-1540, 1997.

CUNHA, R. A.; KOIFFMAN, C. P.; SOUZA, D. H.; TAKEI, K. Clastogenic effects of different Ureaplasma urealyticum serovars on human chromosomes. Braz. J. Med. Biol. Res., v. 30, n. 6, p. 749-757, 1997.

CUNNINGHAM, S. A.; MANDREKAR, J. N.; ROSENBLATT, J. E.; PATEL, R. Rapid PCR Detection of Mycoplasma hominis, Ureaplasma urealyticum, and Ureaplasma parvum. International Journal of Bacteriology, v. 2013, p. 1-7, 2013.

CZURDA, S.; JECHLINGER, W.; ROSENGARTEN, R.; CHOPRADEWASTHALY, R. Xer1-mediated site-specific DNA inversions and excisions in Mycoplasma agalactiae. J. Bacteriol., v. 192, p. 4462-4473, 2010.

DAVID, Y.; BROWNING, G.F.; WISE, K.S. Genetic mechanisms of surface variation. In: RAZIN, S.; HERRMANN, R. (Ed.). Molecular biology and pathogenicity of mycoplasmas. New York, USA: Kluwer Academic, 2002. p. 417-443.

DE FRANCESCO, M.A.; NEGRINI, R.; PINSI, G.; PERONI, L.; MANCA, N. Detection of Ureaplasma biovars and polymerase chain reaction-based subtyping of Ureaplasma parvum in women with or without symptoms of genital infections. Eur. J. Clin. Microbiol. Infect. Dis., v. 28, p. 641-646, 2009.

DE SILVA, N. S.; QUINN, P. A. Localization of endogenous activity of phospholipases A and C in Ureaplasma urealyticum. J. Clin. Microbiol., v. 29, n. 7, p. 1498, 1991.

DENKS, K.; SPAETH, E. L.; JOERS, K.; RANDOJA, R.; TALPSEP, T.; USTAV, M.; KURG, R. Coinfection of Chlamydia trachomatis, Ureaplasma urealyticum and human papillomavirus among patients attending STD clinics in Estonia. Scand. J. Infect. Dis., v. 39, p. 714-718, 2007.

DIAZ, N.; DESSI, D.; DESSOLE, S.; FIORI, P. L.; RAPPELLI, P. Rapid detection of coinfections by Trichomonas vaginalis, Mycoplasma hominis, and Ureaplasma urealyticum by a new multiplex polymerase chain reaction. Diagnostic Microbiology \& Infectious Disease, v. 67, n. 1, p. 30-36, 2010.

DINARELLO, C. A. Biologic basis for interleukin-1 in disease. Blood., v. 87, n. 6 , p. 2095-2147, 1996.

DO VAL, L. F. Desafios da integralidade na atenção às DST/HIV/AIDS: A vulnerabilidade programática nas unidades básicas de saúde do Município 
de São Paulo. 2012. 263 f. Tese (Doutorado em Ciências) - Escola de Enfermagem, Universidade de São Paulo, São Paulo, 2012.

DOMINGUES, D. Micoplasmas: Que papel nas Infecções Humanas? Acta. Med. Port., v. 18, p. 377-384, 2005.

DYBVIG, K.; VOELKER, L. L. Molecular biology of mycoplasmas. Annu. Rev. Microbiol., v. 50, p. 25-27, 1996.

EDWARDS, J. L. Neisseria gonorrhoeae Survival during Primary Human Cervical Epithelial Cell Infection Requires Nitric Oxide and Is Augmented by Progesterone. Infection and immunity, v. 78, n. 3, p. 1202-1213, 2010.

EDWARDS, J. L.; APICELLA, M. A. The molecular mechanisms used by Neisseria gonorrhoeae to initiate infection differ between men and women. Clin. Microbiol. Rev., v. 17, p. 965-981, 2004.

EGGLESTON, E.; ROGERS, S. M.; TURNER, C. F.; MILLER, W. C.; ROMAN, A. M.: HOBBS, M. M.; ERBELDING, E.; TAN, S.; VILLARROEL, M. A.; GANAPATHI, L. Chlamydia trachomatis infection among 15- to 35-year-olds in Baltimore, MD. Sex. Transm. Dis., v. 38, p. 743-749, 2011.

EVANS, B. A. Ultrastructural study of cervical gonorrhea. J. Infect. Dis., v. 136, p. 248-255, 1977.

FALTRACO, F.; BURGER, K.; ZILL, P.; TEIPEL, S. J.; MOLLER, H. J.; HAMPEL, H.; BONDY, B.; ACKENHEIL, M. Interleukin-6-174 G/C promoter gene polymorphism $C$ allele reduces Alzheimer's disease risk. J. Am. Geriatr. Soc., v. 51, p. 578-579, 2003.

FAN, H. H.; KLEVEN, S. H.; JACKWOOD, M. W. Application of polymerase chain reaction with arbitrary primers to strain identification of Mycoplasma gallisepticum. Avian Diseases, v. 39, p. 729-735, 1995.

FETHERS, K. A.; FAIRLEY, C. K.; HOCKING, J. S.; GURRIN, L. C.; BRADSHAW, C. S. Sexual risk factors and bacterial vaginosis: a systematic review and meta-analysis. Clin. Infect. Dis., v. 47, p. 1426-1435, 2008.

FETHERS, K.; TWIN, J.; FAIRLEY, C. K.; FOWKES, F. J. I.; GARLAND, S. M.; FEHLER, G.; MORTON, A. M.; HOCKING, J. S.; TABRIZI, S. N.; BRADSHAW, C. S. Bacterial Vaginosis (BV) Candidate Bacteria: Associations with BV and Behavioural Practices in Sexually-Experienced and Inexperienced Women. PLoS ONE, v. 7, n. 2, 2012.

FICHOROVA, R. N. Impacto of $T$. vaginalis infection on innate immune responses and reproductive outcome. Jornaul of Reproductive Immunology, v. 83, p. 185189, 2009. 
FIORENTINO, D. F.; BOND, M. W.; MOSMANN, T. R. Two types of mouse T helper cell Th2 clones secrete a factor that inhibits cytokine production by Th1 clones. J. Exp. Med., v. 170, p. 2081-2095, 1989.

FISHMAN, D.; FAULDS, G.; JEFFERY, R.; MOHAMED-ALI, V.; YUDKIN, J.S.; HUMPHRIES, S.; WOO, P. The effect of novel polymorphisms in the interleukin-6 (IL-6) gene on IL-6 transcription and plasma IL-6 levels, and an association with systemic-onset juvenile chronic arthritis. J. Clin. Invest., v. 102, n. 7, p. 13691376, 1998.

FLEMING, D. T; WASSERHEIT, J. N. From epidemiological synergy to public health policy and practice: the contribution of other sexually transmitted diseases to sexual transmission of HIV infection. Sex. Transm. Infect., v. 75, n. 1, p. 3-17, 1999.

FORTUNATO, S. J.; MENON, R. Distinct molecular events suggest different pathways for preterm labor and premature rupture of the membranes. Am. J. Obstet. Gynecol., v. 184, p. 184:1399-1406, 2001.

FRASER, C.M.; GOCAYNE, J.D.; WHITE, O.; ADAMS, M.D.; CLAYTON, R. A.; FLEISCHMANN, R. D. The minimal gene complement of Mycoplasma genitalium. Science, v. 270, p. 397-403, 1995.

FREDRICKS, D. N.; FIEDLER, T. L.; THOMAS, K. K.; OAKLEY, B. B.; MARRAZZO, J. M. Targeted PCR for detection of vaginal bacteria associated with bacterial vaginosis. J. Clin. Microbiol., v. 45, p. 3270-3276, 2007.

NAUD, P.; MATOS, J. C.; VETTORAZZI, J.; HAMMES, L. S. Vulvovaginites. In: FREITAS, F.; MENKE, C. H.; RIVOIRE, W. A.; PASSOS, E. P. (Ed.). Rotinas em Ginecologia. 6. ed. Porto Alegre: Artmed, 2011. 736 p.

GARDNER, H. L.; DUKES, C. D. Haemophilus vaginalis vaginitis: a newly defined specific infection previously classified non-specific vaginitis. Am. J. Obstet. Gynecol., v. 69, p. 962-976, 1955.

GARDNER, H. L.; DUKES, C. D. New etiologic agent in nonspecific bacterial vaginitis. Science, v. 120, p. 853, 1954.

GASPARICH, G. E.; WHITCOMB, R. F.; DODGE, D.; FRENCH, F. E.; GLASS, J.; WILLIAMSON, D. L. The genus Spiroplasma and its non-helical descendants: phylogenetic classification, correlation with phenotype and roots of the Mycoplasma mycoides clade. International Journal of Systematic and Evolutionary Microbiology, v. 54, p. 893-918, 2004.

GAYDOS, C. A.; HSIEH, Y.; BARNES, M.; QUINN, N.; AGREDA, P.; JETTGOHEEN, M.; WHITTLE, P.; HOGAN, T. Trichomonas vaginalis infection in women who submit selfobtained vaginal samples after Internet recruitment. Sex. Transm. Dis., v. 38, n. 9, p. 828-832, 2011. 
GELBER, S. E.; AGUILAR, J. L.; LEWIS, K. L. T.; RATNER, A. J. Functional and Phylogenetic Characterization of Vaginolysin, the Human-Specific Cytolysin from Gardnerella vaginalis. Journal of Bacteriology, v. 190, n. 11, p. 3896-3903, 2008.

GERBASE, A. C.; ROWLEY, J. T.; HEYMANN, D. H.; BERKLEY, S. F.; PIOT, P. Global prevalence and incidence estimates selected curable STDs. Sex. Transm. Inf., v. 74, p. 512-516, 1998.

GHYS, P. D.; FRANSEN, K.; DIALLO, M. O.; ETTIEGNE-TRAORE, V.; COULIBALY, I. M.; YEBOUE, K. M.; KALISH, M. L.; MAURICE, C.; WHITAKER, J. P.; GREENBERG, A. E.; LAGA, M. The associations between cervicovaginal HIV shedding, sexually transmitted diseases and immunosuppression in female sex workers in Abidjan, Cote d'Ivoire. AIDS, v. 11, n. 12, p. 85-93, 1997.

GLASS, J. I.; LEFKOWITZ, E. J.; GLASS, J. S.; HEINER, C. R.; CHEN, E. Y.; CASSELL, G. H. The complete sequence of the mucosal pathogen Ureaplasma urealyticum. Nature, v. 407, n. 6805, p. 757-762, 2000.

GOEPFERT, A. R.; VARNER, M.; WARD, K.; MACPHERSON, C.; KLEBANOFF, M.; GOLDENBERG, R. L.; MERCER, B.; MEIS, P.; IAMS, J.; MOAWAD, A.; CAREY, J. C.; LEVENO, K.; WAPNER, R.; CARITIS, S. N.; MIODOVNIK, M.; SOROKIN, Y.; O'SULLIVAN, M. J.; VAN DORSTEN, J. P.; LANGER, O. Differences in inflammatory cytokine and Toll-like receptor genes and bacterial vaginosis in pregnancy. Am. J. Obstet. Gynecol., v. 193, n. 4, p. 1478-1485, 2005.

GREENBLATT, R. M.; BACCETTI, S. P.; BARKAN, M.; AUGENBRAUN, S.; SILVER, R. Lower genital tract infections among HIV-infected and high-risk uninfected women. Sex. Transm. Dis., v. 26, p. 143-151, 1999.

GUIMARÃES, E. M.; GUIMARÃES, M. D.; VIEIRA, M. A.; BONTEMPO, N. M.; SEIXAS, M. S.; GARCIA, M. S.; DAUD, L. E.; CORTES, R. L; ALVES, M. F. Lack of utility of risk score and gynecological examination for screening for sexually transmitted infections in sexually active adolescents. BMC Med., v. 7, p. 8, 2009.

GUPTA, V.; DHAWAN, B.; KHANNA, N.; AGARWAL, N.; BHATTACHARVA, S. N.; SREENIVAS, V.; CHAUDHRY, R. Detection and biovar discrimination of Ureaplasma urealyticum in Indian patients with genital tract infections. Diagnostic Microbiology and Infectious Disease, v. 60, n. 1, p. 95-97, 2008.

HAGGERTY, C. L.; NESS, R. B. Epidemiology, pathogenesis and treatment of pelvic inflammatory disease. Expert. Rev. Anti. Infect. Ther., v. 4, p. 235-247, 2006.

HAGGERTY, C. L.; TOTTEN, P. A.; FERRIS, M.; MARTIN, D. H.; HOFERKA, S.; ASTETE, S. G.; ONDONDO, R.; NORORI, J.; NESS, R. B. Clinical characteristics of bacterial vaginosis among women testing positive for fastidious bacteria. Sex. Transm. Infect., v. 85, p. 242-248, 2009. 
HEDGES, S. R.; SIBLEY, D. A.; MAYO, M. S.; HOOK, E. W.; RUSSEL, M. W. Cytokine and antibody responses in women infected with Neisseria gonorrhoeae: effects of concomitant infections. J. Infect. Dis., v. 178, p. 742-751, 1998.

HERNANDEZ-GUERRERO, C.; MONZON-BORDONABA, F.; JIMENEZAMUDIO, L.; AHUED-AHUED, R.; ARECHAVALETA-VELASCO, F.; STRAUSS, J. F.; VADILLO-ORTEGA, F. In-vitro secretion of proinflammatory cytokines by human amniochorion carrying hyper-responsive gene polymorphisms of tumour necrosis factor-a and interleukin-1b. Mol. Hum. Reprod., v. 9, p. 625-629, 2003.

HERNÁNDEZ-MARTÍNEZ, F.; HERNÁNDEZ-GARCÍA, J. A.; MARTÍNEZ-PEÑA, M. D.; MUÑÍZ-BECERRIL, B. L.; HERNÁNDEZ-CORTEZ, C.; CASTROESCARPULLI, G.; AGUILERA-ARREOLA, M. G. Aetiology and frequency of cervico-vaginal infections among Mexican women. African Journal of Microbiology Research, v. 7, n. 1, p. 27-34, 2013.

HILLIER, S. L. The vaginal microbial ecosystem and resistance to HIV. AIDS Res. Hum. Retrovirol., v. 14, p. 517-521, 1998.

HOCKING, J. S.; WILLIS, J.; TABRIZI, S.; FAIRLEY, C. K.; GARLAND, S. M.; HELLARD, M. A chlamydia prevalence survey of young women living in Melbourne, Victoria. Sexual Health, v. 3, n. 4, p. 235-240, 2006.

HOLLEGAARD, M. V.; BIDWELL, J. L. Cytokine gene polymorphism in human disease. Genes. Immun., v. 7, p. 269-276, 2006.

HUMBURG, J.; FREI, R.; WIGHT, E.; TROEGER, C. Accuracy of urethral swab and urine analysis for the detection of Mycoplasma hominis andUreaplasma urealyticum in women with lower urinary tract symptoms. Archives of Gynecology and Obstetrics, v. 285, n. 4, p. 1049-1053, 2012.

INGIANNI, A.; PETRUZZELLI, S.; MORANDOTTI, G.; POMPEI, R. Genotypic differentiation of Gardnerella vaginalis by amplified ribosomal DNA restriction analysis (ARDRA). FEMS Immunology and Medical Microbiology, v. 18, p. 6166, 1997.

INSTITUTO BRASILEIRO DE GEOGRAFIA E ESTATÍSTICA (IBGE). Censo Brasileiro 2012. Disponível em: <http://www.ibge.gov.br/home/>. Acesso em: 10 Mai. 2013.

JEREMIAS, J.; GIRALDO, P.; DURRANT, S.; RIBEIRO-FILHO, A.; WITKIN, S. S. Relationship between Ureaplasma urealyticum Vaginal Colonization and Polymorphism in the Interleukin-1 Receptor Antagonist Gene. The Journal of Infectious Diseases., v. 180, p. 912-914, 1999.

JONES, J. A.; CHABAN, N.; MAY, M. Global Rates and Prevalence of Urogenital Mycoplasmosis: Assembly of a Dataset from Peer-Reviewed Literature. Open Journal of Medical Microbiology, v. 3, p. 105-124, 2013. 
KAARTHIKEYAN, G.; JAYAKUMAR, N. D.; PADMALATHA, O.; SHEEJA, V.; SANKARI, M.; ANANDAN, B. Analysis of the association between interleukin-1b $(+3954)$ gene polymorphism and chronic periodontitis in a sample of the south Indian population. Indian. J. Dent. Res., v. 20, n. 1, p. 37-40, 2009.

KATAOKA, S.; YAMADA, T.; CHOU, K.; NISHIDA, R.; MORIKAWA, M.; MINAMI, M.; YAMADA, H.; SAKURAGI, N.; MINAKAMI, H. Association between Preterm Birth and Vaginal Colonization by Mycoplasmas in Early Pregnancy. Journal of Clinical Microbiology, v. 44, n. 1, p. 51-55, 2006.

KELLAM, P.; WEISS, R. A. Infectogenomics: Insights from the Host Genome into Infectious Diseases. Cell, v. 124, 2006.

KENT, C. K.; CHAW, J. K.; WONG, W.; LISKA, S.; GIBSON, S.; HUBBARD, G.; KLAUSNER, J. D. Prevalence of rectal, urethral, and pharyngeal chlamydia and gonorrhea detected in 2 clinical settings among men who have sex with men: San Francisco, California, 2003. Clin. Infect. Dis., v. 41, p. 67-74, 2005.

KIM, S.; LEE, D. S.; LEE, S. The prevalence and clinical significance of urethritis and cervicitis in asymptomatic people by use of Multiplex Polymerase Chain Reaction. Korean J. Urol., v. 52, n. 10, p. 703-708, 2011.

KLEBANOFF, M. A.; CAREY, J. C.; HAUTH, J. C.; HILLIER, S. L.; NUGENT, R. P.; THOM, E. A.; ERNEST, J. M.; HEINE, R. P.; WAPNER, R. J. TROUT, W.; MOAWAD, A.; MIODOVNIK, M.; SIBAI, B. M.; DORSTEN, J. P. V.; DOMBROWSKI, M. P.; O'SULLIVAN, M. J.; VARNER, M.; LANGER, O.; MCNELLIS, D.; ROBERTS, J. M. LEVENO, K. J. The National Institute of Child Health Human Development Network of Maternal-Fetal Medicine Units. Failure of metronidazole to prevent preterm delivery among pregnant women with asymptomatic Trichomonas vaginalis infection. New England Journal of Medicine, v. 345, p. 487-493, 2001.

KLEBANOFF, MARK A.; SCHWEBKE, JANE R.; ZHANG, J.; NANSEL, TONJA R.; YU, KAI-FUN; ANDREWS, WILLIAM W. Vulvovaginal Symptoms in Women With Bacterial Vaginosis. Obstetrics \& Gynecology, v. 104, n. 2, p. 267-272, 2004.

KNOX, C. L.; ALLAN, J. A.; ALLAN, J. M.; EDIRISINGHE, W. R.; STENZEL, D.; LAWRENCE, F. A.; PURDIE, D. M.; TIMMS, P. Ureaplasma parvum and Ureaplasma urealyticum are detected in semen after washing before assisted reproductive technology procedures. Fertil. Steril., v. 80, n. 4, p. 921-929, 2003.

KOEDIJK, F. D. H.; VAN BERGEN, J. E. A. M.; DUKERS-MUIJRERS, N. H. T. M.; VAN LEEUWEN, A. P.; HOEBE, C. J. P. A.; VAN DER SANDE, M. A. B. The value of testing multiple anatomic sites for gonorrhoea and chlamydia in sexually transmitted infection centres in the Netherlands, 2006-2010. International Journal of STD \& AIDS, v. 23, p. 626-631, 2012. 
KONG, F.; HOCKING, J. S.; LINK, C. K.; CHEN, M. Y.; HELLARD, M. E. Sex and sport: chlamydia screening in rural sporting clubs. BMC Infectious Diseases, v. 9, n. 1, p. 73, 2009.

KONG, F.; JAMES, G.; MA, Z.; GORDON, S.; WANG, B.; GILBERT, G. L. Phylogenetic analysis of Ureaplasma urealyticum-support for the establish- ment of a new species, Ureaplasma parvum. Int. J. Syst. Bacteriol., v. 49, p. 18791889, 1999.

KONG, F.; MA, Z.; JAMES, G.; GORDON, S.; GILBERT, G.L. Molecular genotyping of human Ureaplasma species based on multiple-banded antigen (MBA) gene sequences. Int. J. Syst. Evol. Microbiol., v. 50, p. 1921-1929, 2000.

KOUMANS, E. H.; STERNBERG, M.; BRUCE, C.; MCQUILLAN, G.; KENDRICK, J.; et al. The prevalence of bacterial vaginosis in the United States, 2001-2004; associations with symptoms, sexual behaviors, and reproductive health. Sex. Transm. Dis., v. 34, p. 864-869, 2007.

KRAUSE, D. C; TAYLOR-ROBINSON, D. Mycoplasmas which infect humans. In: MANILOFF, J.; MCELHANEY, R. N.; FINCH, L. R.; BASEMAN, J. B. (Ed.). Mycoplasmas: molecular biology and pathogenesis. Washington (DC): American Society for Microbiology, 1992. p. 417-444.

KRIEGER, J. N. Trichominiasis in men: old issues and new data. Sex. Transm. Dis., v. 22, p. 83-96, 1995.

KUCINSKIENE, V.; SUTAITE, I.; VALIUKEVICIENE, S.; MILASAUSKIENE, Z.; DOMEIKA, M. Prevalence and risk factors of genital Chlamydia trachomatis infection. Medicina, v. 42, n. 11, p. 885-894, 2006.

LABARĖRE, J. DNA replication and repair. In: MANILOFF, J.; MCELHANEY, R. N.; FINCH, L. R.; BASEMAN, J. B. (Ed.). Mycoplasmas: molecular biology and pathogenesis. Washington: American Society for Microbiology, 1992. p. 309323.

LAINE, M. L.; LOOS, B. G.; CRIELAARD, W. Gene Polymorphisms in Chronic Periodontitis. International Journal of Dentistry, 2010.

LARSSON, P. G.; BERGSTROM, M.; FORSUM, U.; JACOBSSON, B.; STRAND, A.; WOLNER-HANSSEN, P. Bacterial vaginosis, transmission, role in genital tract infection and pregnancy outcome: an enigma. APMIS, v. 113, p. 233-245, 2005.

LEOPOLD, S. Heretofore undescribed organism isolated from the geni-tourinary system. U. S. Armed. Forces Med. J., v. 4, p. 263-266, 1953.

LICASTRO, F.; VEGLIA, F.; CHIAPPELLI, M.; GRIMALDI, L. M.; MASLIAH, E. A polymorphism of the interleukin-1b gene at position p3953 influences progression and neuro-pathological hallmarks of Alzheimer's disease. Neurobiol. Aging., v. 25, p. 1017-1022, 2004. 
LIMA, Y. A. R.; ALVES, M. F. C. O sistema imune da mucosa do trato genital feminino e o impacto das doenças sexualmente transmissíveis. Rev. Patol. Tropic., v. 37, n. 4, p. 295-309, 2008.

LINHARES, I. M.; GIRALDO, P. C.; BARACAT, E. C. Novos conhecimentos sobre a flora bacteriana vaginal. Rev. Assoc. Med. Brás., v. 56, n. 3, p. 370-374, 2010.

LIU, T.; GARCÍA, M.; LEVISOHN, S.; YOGEV, D., KLEVEN, S. H. Molecular variability of the adhesin-encoding gene pvpA among Mycoplasma gallisepticum strains and its application in diagnosis. J. Clin. Microbiol., v. 39, n. 5, p. 18821888, 2001.

LIVENGOOD, C. H.; WRENN, J. W. Evaluation of COBAS AMPLICOR (Roche): Accuracy in Detection of Chlamydia trachomatis and Neisseria gonorrhoeae by Coamplification of Endocervical Specimens. Journal of Clinical Microbiology, v. 39, n. 8, p. 2928-2932, 2001.

LOPEZ, N. J.; JARA, L.; VALENZUELA, C. Y. Association of interleukin-1 polymorphisms with periodontal disease. J. Periodontol., v. 76, p. 234-243, 2005.

MACHADO, P. R. L.; ARAÚJO, I. A. S. A.; CARVALHO, L.; CARVALHO, E. M. Mecanismos de resposta imune às infecções. An. Bras. Dermatol., v. 79, p. 647664, 2004.

MACIEL, G. P.; TASCA, T.; CARLI, G. A. Aspectos clínicos, patogênese e diagnóstico de Trichomonas vaginalis. J. Bras. Patol. Med. Lab., v. 40, n. 3, p. 152-160, 2004.

MAEDA, S.; DEGUCHI, T.; ISHIKO, H.; MATSUMOTO, T.; NAITO, S.; KUMON, H.; TSUKAMOTO, T.; ONODERA, S.; KAMIDONO, S. Detection of Mycoplasma genitalium, Mycoplasma hominis, Ureaplasma parvum (biovar 1) and Ureaplasma urealyticum (biovar 2) in patients with non-gonococcal urethritis using polymerase chain reaction-microtiter plate hybridization. International Journal of Urology, $v$. 11, n. 9, p. 750-754, 2004.

MAHONY, J. B.; LUINSTRA, K. E.; TYNDALL, M.; SELLORS, J. W.; KREPEL, J.; CHERNESKY, M. Multiplex PCR for Detection of Chlamydia trachomatis and Neisseria gonorrhoeae in Genitourinary Specimens. Journal of Clinical Microbiology, v. 33, n. 11, p. 3049-3053, 1995.

MANHART, L. E.; HOLMES, K. K.; HUGHES, J. P.; HOUSTON, L. S.; TOTTEN, P. A. Mycoplasma genitalium Among Young Adults in the United States: An Emerging Sexually Transmitted Infection. American Journal of Public Health, $v$. 97, n. 6, p. 1118-1125, 2007.

MANHART, L.E.; CRITCHLOW, C.W.; HOLMES, K.K. Mucopurulent cervicitis and Mycoplasma genitalium. J. Infect. Dis., v. 187, p. 650-657, 2003. 
MANILOFF, J. Phylogeny and evolution. In: RAZIN, S.; HERRMANN, R. (Ed.). Molecular biology and pathogenicity of mycoplasmas, New York: Kluwer Academic, 2002. p. 31-43.

MARQUES, L. M.; UENO, P. M.; BUZINHANI, M.; CORTEZA, B. A.; NETO, R. L.; YAMAGUTI, M.; OLIVEIRA, R. O.; GUIMARÃES, A. M. S.; MONEZI, T. A.; BRAGA JÚNIOR, A. C. R.; MACHADO-SANTELLI, G. M.; TIMENETSKY, J. Invasion of Ureaplasma diversum in Hep-2 cells. BMC Microbiology, v. 10, p. 83, 2010.

MARRAZZO, J. M.; THOMAS, K. K.; FIEDLER, T. L.; RINGWOOD, K.; FREDRICKS, D. N. Relationship of specific vaginal bacteria and bacterial vaginosis treatment failure in women who have sex with women. Ann. Intern. Med., v. 149, p. 20-28, 2008.

MARRAZZO, M. J. Interpreting the Epidemiology and Natural History of Bacterial Vaginosis: Are We Still Confused? Anaerobe, v. 17, n. 4, p. 186-190, 2011.

MARTIN, I. M.; ISON, C. A.; AANENSEN, D. M.; FENTON, K. A.; SPRATT, B. G. Rapid sequence-based identification of gonococcal transmission clusters in a large metropolitan area. J. Infect. Dis., v. 189, p. 1497-1505, 2004.

MASCARENHAS, R. E. M.; CUNHA MACHADO, M. S.; SILVA, B. F. B. C.; PIMENTEL, R. F. W.; FERREIRA, T. T.; LEONI, F. M. S.; GRASSI, M. F. R. Prevalence and risk factors for Bacterial Vaginosis and other Vulvovaginitis in a population of sexually active adolescents from Salvador, Bahia, Brazil. Infectious Diseases in Obstetrics and Gynecology, 2012.

MCCLELLAND, R. S.; SANGARE, L.; HASSAN, W. M.; LAVREYS, L.; MANDALIYA, K.; KIARIE, J.; NDINYA-ACHOLA, J.; JAOKO, W.; BAETEN, J. M. Infection with Trichomonas vaginalis Increases the Risk of HIV-1 Acquisition. The Journal of Infectious Diseases, v. 195, p. 698-702, 2007.

MCGOWIN, C. L.; POPOV, V. L.; PYLES, R. B. Intracellular Mycoplasma genitalium infection of human vaginal and cervical epithelial cells elicits distinct patterns of inflammatory cytokine secretion and provides a possible survival niche against macrophage-mediated killing. BMC Microbiol., v. 9, p. 139, 2009.

MCIVER, C. J.; RISMANTO, N.; SMITH, C.; NAING, Z. W.; RAYNER, B.; LUSK, M. J.; KONECNY, P.; WHITE, P. A.; RAWLINSON, W. D. Multiplex PCR Testing Detection of Higher-than-Expected Rates of Cervical Mycoplasma, Ureaplasma, and Trichomonas and Viral Agent Infections in Sexually Active Australian Women. Journal of Clinical Microbiology, v. 47, n. 5, p. 1358-1363, 2009.

MCKECHNIE, M. L.; HILLMAN, R. J.; JONES, R. The prevalence of urogenital micro-organisms detected by a multiplex PCR reverse line blot assay in women attending three sexual health clinics in Sydney, Australia. Journal of Medical Microbiology, v. 60, n. 7, p. 1010-1016, 2011. 
MEDEIROS, R. H. A. - Notas Críticas à obra de Tranquilino Torres. In: TORRES, T. O município de Vitória da Conquista. Vitória da Conquista: Museu Regional de Vitória da Conquista/UESB, 1996. p. 63-163.

MGONE, C. S.; LUPIWA, T.; YEKA, W. High prevalence of Neisseria gonorrhoeae and multiple sexually transmitted diseases among rural women in the eastern Highlands Province of Papua New Guinea, detected by polymerase chain reaction. Sexually Transmitted Diseases, v. 29, n. 1, p. 775-779, 2002.

MILES, R. J.; NICHOLAS, R. A. J. Methods in molecular biology Mycoplasma protocols. Totowa, NJ: Humana Press, 1998. 336 p.

MIRANDA, A. E.; SZWARCWALD, C. L.; PERES, R. L; PAGE-SHAFER, K. Prevalence and risk behaviors for chlamydial infection in a population-based study of female adolescents in Brazil. Sex. Transm. Dis., v. 31, p. 542-546, 2004.

MIRANDA, A.E; GADELHA, A.M.J.; PASSOS, M.R.L. Impacto da Infecção pela Chlamydia trachomatis na Saúde Reprodutiva. J. Bras. Doenças Sex. Transm., v. 15, n. 1, p. 53-58, 2003.

MITCHELL, L.; HUSSEY, D. J. Trichomonas vaginalis: an unusual presentation. International Journal of STD \& AIDS, v. 21, p. 664-665, 2010.

MOREIRA, P. R.; LIMA, P. M. Interleukin-6 expression and gene polymorphism are associated with severity of periodontal disease in a sample of Brazilian individuals. Clin. Exp. Immunol., v. 148, n. 1, p. 119-126, 2007.

MOROWITZ, H. J. Foreword: from the enigmatic pleuropneumonia-like organisms to the paradigmatic mycoplasma. In: RAZIN, S.; HERRMANN, R. (Ed.). Molecular biology and pathogenicity of mycoplasmas. New York: Kluwer Academic/Plenum Publishers, 2002. p. 5-8.

MUELLER-HEUBACH, E.; RUBINSTEIN, D. W.; SCHWARZ, S. S. Histologic chorioamnionitis and preterm delivery in different patients populations. Obstet. Gynecol., v. 75, p. 622-626, 1990.

MURTA, E. F. C.; SOUZA, M. A. H.; ARAÚJO JÚNIOR, E.; ADAD, S. J. Incidence of Gardnerella vaginalis, Candida sp and human papilloma virus in cytological smears. Rev. Paul. Med., v. 118, n. 4, p. 105-108, 2000.

NIBALI, L.; DONOS, N.; FARRELL, S.; READY, D.; PRATTEN, J.; TU, Y. K.; D'AIUTO, F. Association Between Interleukin-6 -174 Polymorphism and Aggregatibacter actinomycetemcomitans in Chronic Periodontitis. $J$. Periodontol., v. 81, n. 12, 2010.

NICOLSON, G. L.; NASRALIA, M. Y.; NICOLSON, N. L. The pathogenesis and treatment of mycoplasma infection. Antimicrob. Infect. Dis. Newslet., v. 17, n. 11, p. 81-88, 1999. 
NJUNDA, A. L.; NSAGHA, D. S.; ASSOB, J. C. N.; PALLE, J. N.; KAMGA, H. L.; NDE, P. F.; NTUBE, M. N. C.; WELEDJI, P. E. Genital mycoplasmas in women attending the Yaoundé University Teaching Hospital in Cameroon. Journal of Public Health in Africa, v. 2, p. 16, 2011.

NUGENT, R. P., M. A. KROHN, AND S. L. HILLIER. Reliability of diagnosing bacterial vaginosis is improved by a standardized method of Gram stain interpretation. J. Clin. Microbiol., v. 29, p. 297-301, 1991.

OBATA-YASUOKA, M.; BA-THEIN, W.; HAMADA, H.; HAYASHI, H. A multiplex polymerase chain reaction-based diagnostic method for bacterial vaginosis. Obstet. Gynecol., n. 100, p. 759-764, 2002.

OHMAN, H.; TIITINEN, A.; HALTTUNEN, M.; PAAVONEN, J.; SURCEL, H. M.; Cytokine gene polymorphism and Chlamydia trachomatis-specific immune responses. Hum. Immunol., v. 72, n. 3, p. 278-282, 2011.

OITTINEN, J.; KURKI, T.; KEKKI, M.; PUSSINEN, P.; VILKUNA-RAUTIAINEN, T.; NIEMINEN, A.; ASIKAINEN, S.; PAAVONEN, J. Periodontal disease and bacterial vaginosis increase the risk for adverse pregnancy outcome. Infect. Dis. Obstet. Gynecol., v. 13, p. 213-216, 2005.

OLMSTED, S. S.; MEYN, L. A.; ROHAN, L. C.; HILLIER, S. L. Glycosidase and proteinase activity of anaerobic gram-negative bacteria isolated from women with bacterial vaginosis. Sex. Transm. Dis., v. 30, p. 257-261, 2003.

OLSON, L. D.; RENSHAW, C. A.; ROTTEM, S.; BOAL, J. H. Arginine utilization by Mycoplasma fermentans is not regulated by glucose metabolismo 13C-NMR study. FEMS Microbiol. Lett., v. 108, n. 47-52, 1993.

ONDONDO, R. O.; WHITTINGTON, W. L. H.; ASTETE, S. G.; TOTTEN, P. A. Differential association of ureaplasma species with non-gonococcal urethritis in heterosexual men. Sex. Transm. Infect., v. 86, p. 271-275, 2010.

ONOYA, D.; REDDY, P.; SIFUNDA, S.; LANG, D.; WINGOOD, G. M.; VAN DEN BORNE, B.; RUITER, R. A. C. Transactional Sexual Relationships, Sexually Transmitted Infection Risk, and Condom Use among Young Black Women in PeriUrban Areas of the Western Cape Province of South Africa. Women's Health Issues, v. 22, n. 3, p. 277-282, 2012.

OYEWOLE, I. O.; ANYASOR, G. N.; MICHAEL-CHIKEZIE, E. C. Prevalence of STI Pathogens in HIV- Infected and Non-Infected Women: Implications for Acquisition and Transmission of Hiv in Nigeria. Asian Journal of Medical Sciences, v. 2, n. 3, p. 163-166, 2010.

PAAVONEN, J.; LEHTINEN, M. Chlamydia pelvic inflammatory disease. Human Reproduction Update, p. 519-529, 1996.

PARALANOV, V.; LU, J.; DUFFY, L. B.; CRABB, D. M.; SHRIVASTAVA, S.; METHÉ, B. A.; INMAN, J.; YOOSEPH, S.; XIAO, L.; CASSELL, G. H.; WAITES, K. B.; GLASS, J. I. Comparative genome analysis of 19 Ureaplasma urealyticum and Ureaplasma parvum strains. BMC Microbiology, v. 12, p. 88, 2012. 
PATEL, M. A.; NYIRJESY, P. Role of mycoplasma and ureaplasma species in female lower genital tract infections. Curr. Infect. Dis. Rep., v. 12, n. 6, p. 417422, 2010.

PATTERSON, J. L.; STULL-LANE, A.; GIRERD, P. H.; JEFFERSON, K. K. Analysis of adherence, biofilm formation and cytotoxicity suggests a greater virulence potential of Gardnerella vaginalis relative to other bacterial- vaginosisassociated anaerobes. Microbiology, v. 156, p. 392-399, 2010.

PAWLIK, A.; KURZAWSKI, M.; FLORCZAK, M.; GAWRONSKA, S. B.; HERCZYNSKA, M. IL-1beta p3953 exon 5 and IL-2 -330 promoter polymorphisms in patients with rheumatoid arthritis. Clin. Exp. Rheumatol., v. 23, p. 159- 164, 2005.

PEIPERT, J.F. Clinical practice. Genital chlamydial infections. N. Engl. J. Med., v. 349, p. 2424- 2430, 2003.

PETRIN, D.; DELGATY, K.; BHATT, R.; GARBER, G. Clinical and microbiological aspects of Trichomonas vaginalis. Clin. Microbiol. Rev., v. 11, p. 300-317, 1998.

PETROVAY, F.; BALLA, E.; NÉMETH, I.; GONCZOL, E. Genotyping of Chlamydia trachomatis from the endocervical specimens of high-risk women in Hungary. Journal of Medical Microbiology, n. 58, p. 760-764, 2009.

PILO, P.; VILEI, E. M.; PETERHANS, E.; BONVIN-KLOTZ, L.; STOFFEL, M. H.; DOBBELAERE, D.; FREY, J. A Metabolic Enzyme as a Primary Virulence Factor of Mycoplasma mycoides subsp. mycoides Small Colony. Journal Of Bacteriology, v. 187, n. 19, p. 6824-6831, 2005.

PLATT, R.; RICE, P.A.; Mc CORMACK, W.M. Risk of acquiring gonorrhea and prevalence of abnormal adnexal findings among women recently exposed to gonorrhea. JAMA, v. 250, p. 3205-3209, 1983.

POVLSEN, K.; THORSEN, P.; LIND, I. Relationship of Ureaplasma urealyticum biovars to the presence or absence of bacterial vaginosis in pregnant women and to the time of delivery. Eur. J. Clin. Microbiol. Infect. Dis., v. 20, p. 65-67, 2001.

QUINN, T. C. Association of sexually transmitted diseases and infection with the human immunodeficiency virus: biological cofactors and markers of behavioural interventions. Int. J. STD AIDS., v. 7, n. 2, p. 17-24, 1996.

RAZIN, S. DNA probes and PCR in diagnosis of mycoplasma infections. Mol. Cell. Probes., v. 8, p. 497-511, 1994.

RAZIN, S. Molecular properties of Mollicutes: a synopsis. In: RAZIN, S.; TULLY, J. G. (Ed.). Molecular and diagnostic procedures in mycoplasmology. San Diego: Academic Press, 1995. v. 1, p. 1-25. 
RAZIN, S. Mycoplasma taxonomy and ecology. In: MANILOFF, J.; CELHANEY, R. N.; FINCH, L. R.; BASEMAN, J. B. (Ed.). Mycoplasmas, molecular biology and pathogenesis. Washington: American Society For Microbiology, 1992. p. 322.

RAZIN, S. Mycoplasmas: General concepts. Medical Microbiology, 2004. Disponível em: <http://gsbs.utmb.edu/microbook/ch037.htm>. Acesso em 14 Mar. 2012.

RAZIN, S. The mycoplasmas. Microbiol. Rev., v. 42, p. 414-470, 1978.

RAZIN, S.; BARILE, M. F. Mycoplasma pathogenicity. In: RAZIN, S.; BARILE, M. F. (Ed.). The mycoplasmas. Orlando: Academic Press, 1985. v. 4, p. 161-202.

RAZIN, S.; JACOBS, E. Mycoplasma adhesion. J. Gen. Microbiol., v. 138, p. 407-422, 1992.

RAZIN, S.; YOGEV, D.; NAOT, Y. Molecular biology and pathogenicity of Mycoplasma. Microbiol. Mol. Biol. Rev., p. 1094-1156, 1998.

REYES, L.; REINHARD, M.; O'DONELL, L. J.; STEVENS, J.; BROWN, M. B. Rat strains differ in susceptibility to Ureaplasma parvum-induced urinary tract infection and struvite stone formation. Infect Immun., v. 74, p. 6656-666, 2006.

REYES, L.; REINHARD, M.; BROWN, M. B. Different inflammatory responses are associated with Ureaplasma parvum-induced UTI and urolith formation. BMC Infect. Dis., v. 9, p. 9, 2009.

RILEY, D. E.; ROBERTS, M. C.; TAKAYAMA, T.; KRIEGER, J. N. Development of a Polymerase Chain Reaction-Based Diagnosis of Trichomonas vaginalis. Journal of Clinical Microbiology, v. 30, n. 2, p. 465-472, 1992.

RIZZO, G.; CAPPONI, A.; VLACHOPOULOU, A.; ANGELINI, E.; GRASSI, C.; ROMANINI, C. Interleukin-6 concentrations in cervical secretions in the prediction of intrauterine infection in preterm premature rupture of the membranes. Gynecol. Obstet. Invest., v. 46, p. 91-95, 1998.

ROBERTSON, J. A.; STEMKE, G. W.; DAVIS, J.; HARASAWA, R.; THIRKELL, D.; KONG, F.; SHEPARD, M. C.; FORD, D. K. Proposal of Ureaplasma parvum sp. nov. and emended description of Ureaplasma urealyticum. Int. J. Syst. Evol. Microbiol., v. 52, p. 587-597. 2002.

ROBINSON, J. W.; DANDO, S. J.; NITSOS, I.; NEWNHAM, J.; POLGLASE, G. R.; KALLAPUR, S. G.; PILLOW, J. J.; KRAMER, B. W.; JOBE, A. H.; PAYTON, D.; KNOX, C. L. Ureaplasma parvum Serovar 3 Multiple Banded Antigen Size Variation after Chronic Intra-Amniotic Infection/Colonization. PLOS ONE, v. 8, n. 4, 2013.

ROCK, K. L.; LATZ, E.; ONTIVEROS, F.; KONO, H. The sterile inflammatory response. Annu. Rev. Immunol., v. 28, p. 321-342, 2010. 
ROMERO, R.; AVILA, C.; SANTHANAM, U.; SEHGAL, P. B. Amniotic fluid interleukin 6 in preterm labor. Association with infection. J. Clin. Invest., v. 85, p. 1392-1400, 1990.

ROSE, M.; VISCARDI, M. D. Ureaplasma species: Role in Diseases of Prematurity. Clin. Perinatol., v. 37, n. 2, p. 393-409, 2010.

ROSENGARTEN, R.; YOGEV, D. Variant colony surface antigenic phenotypes within mycoplasma strain populations: implications for species diagnosis and strain standardization. J. Clin. Micobiol., v. 34, p. 149-158, 1996.

ROSENSTEIN, I. J.; MORGAN, D. J.; SHEEHAN, M.; LAMONT, R. F.; TAYLORROBINSON, D. Bacterial vaginosis in pregnancy: distribution of bacterial species in different gram-stain categories of the vaginal flora. J. Med. Microbiol., v. 44, p. 1-7, 1996.

ROTTEM, S. Invasion of mycoplasmas into and fusion with host cells. In: RAZIN, S. AND HERRMANN, R. (Ed.). Molecular Biology and Pathogenicity of Mycoplasmas. New York: Kluwer Academic, 2002. p. 391-401.

ROTTEM, S. Invasion of mycoplasmas into and fusion with host cells. In: RAZIN, S.; HERRMANN, R. (Ed.). Molecular Biology and Pathogenicity of Mycoplasmas. New York: Kluwer Academic, 2002. p. 391-401.

ROTTINI, G.; DOBRINA, A.; FORGIARINI, O.; NARDON, E.; AMIRANTE, G. A.; PATRIARCA, P. Identification and partial characterization of a cytolytic toxin produced by Gardnerella vaginalis. Infect. Immun., v. 58, p. 3751-3758, 1990.

RUHNKE, H. L.; ROSENDAL, S. Useful protocols for diagnosis of animal mycoplasmas. In: WHITFORD, H. W., ROSENBUSCH, R. F., LAUERMAN, L. H. (Ed.). Mycoplasmosis in Animals: Laboratory Diagnosis. lowa: lowa State University Press, 1994. p. 141-144.

RUST, S.; FUNKE, H.; ASSMANN, G. Mutagenically separated PCR (MS-PCR): a highly specific one step procedure for easy mutation detection. Nucleic Acids Research, v. 21, n. 16, p. 3623-3629, 1993.

SALAH, R. M.; ALLAM, A. M.; MAGDY, A. M.; MOHAMED, A. S. Bacterial vaginosis and infertility: cause or association? European Journal of Obstetrics \& Gynecology and reproductive biology, v. 167, p. 59-63, 2013.

SALFA, M. C.; LATINO, M. A.; REGINE, V.; MARIA, D.; INTINIS, G.; CAMONI, L.; RAIMONDO, M.; SULIGOI, B. Prevalence and determinants of Chlamydia trachomatis infection among sexually active women in Turin, Italy. Italian Journal of Public Health, v. 8, n. 3, 295-301, 2011.

SATO, H.; CHINEN, P.A.; MATTAR, A.; SARTORI, M.G.F.; GIRÃO, M.J.B.C. Doença Inflamatória Pélvica. In: BARACAT, E.C.; LIMA, G.R. Guias de medicina ambulatorial e hospitalar de ginecologia. São Paulo: Manole, 2005. 698 p. 
SCHLICHT, M. J.; LOVRICH, S. D.; SARTIN, J. S.; KARPINSKY, P.; CALLISTER, S. M.; AGGER, W. A. High prevalence of genital mycoplasmas among sexually active young adults with urethritis or cervicitis symptoms in La Crosse, Wisconsin. J. Clin. Microbiol., v. 42, n. 10, p. 4636-40, 2004.

SCHOTTE, H.; SCHLUTER, B.; RUST, S.; ASSMAN, G.; DOMSCHKE, W.; GAUBITZ. M. Interleukin-6 promoter polymorphism $(-174 \mathrm{G} / \mathrm{C})$ in Caucasian german patients with systemic lupus erythematosus. Rheumatology, v. 40. p. 393-400, 2001.

SCOTT, L. D.; BASTER, K.; EMMETT, L.; NICHOLS, T.; RANDALL, S.; MCLEAN, L.; MEREDITH, P.; HARINDRA, V.; TOBIN, J. M.; UNDERHILL, G. S.; GRAHAM, H. W.; HOPWOOD, J.; GLEAVE, T.; GHOSH, A. K.; MALLINSON, H.; DAVIES, A. R.; HUGHES, G.; FENTON, K. A. Incidence and reinfection rates of genital chlamydial infection among women aged 16-24 years attending general practice, family planning and genitourinary medicine clinics in England: a prospective cohort study by the chlamydia recall study advisory group. Sex. Transm. Infect., v. 83, p. 292-303, 2007.

SHA, B. E.; CHEN, H. Y.; WANG, Q. J.; ZARIFFARD, M. R.; COHEN, M. H.; SPEAR, G. T. Utility of Amsel Criteria, Nugent Score, and Quantitative PCR for Gardnerella vaginalis, Mycoplasma hominis, and Lactobacillus spp. for Diagnosis of Bacterial Vaginosis in Human Immunodeficiency Virus-Infected Women. Journal Of Clinical Microbiology, v. 43, n. 9, p. 4607-4612, 2005.

SHAO, M.; HUANG, P.; CHENG, R.; HU, T. Interleukin-6 polymorphisms modify the risk of periodontitis: a systematic review and meta-analysis. J. Zhejiang Univ. Sci. B., v. 10, n. 12, p. 920-927, 2009.

SILVA FILHO, A. M.; LONGATTO FILHO, A. Colo Uterino e Vagina. Processos Inflamatórios. Aspectos Histológicos, Citológicos e Colposcópicos. Rio de Janeiro: Revinter, 2000. 209 p.

SIMOES, J. A. O papel dos micoplasmas nas infecções genitais femininas. Rev. Atualiz. Ginecol. Obstet., v. 8, p. 30-37, 1999.

SOBEL, J. Current concepts: vaginitis. N. Engl. J. Med., v. 337, p. 1896-903, 1997.

SOBEL, J. D. Bacterial vaginosis. Annu. Rev. Med., v. 51, p. 349-356, 2000.

SPURBECK, R. R.; ARVIDSON, C. G. Inhibition of Neisseria gonorrhoeae epithelial cell interactions by vaginal Lactobacillus species. Infect Immun., v. 76, p. 3124-3130, 2008.

STAMM, W.E.; GUINAN, M.E.; JOHNSON, C. et al. Effect of treatment regimens for Neisseria gonorrhoeae on simultaneous infection with Chlamydia trachomatis. N. Engl. J. Med., n. 310, p. 545-549, 1984. 
STURM-RAMIREZ, K.; GAYE-DIALLO, A.; EISEN, G.; MBOUP, S.; KANKI, P. J. High levels of tumor necrosis factor-alpha and interleukin-1beta in bacterial vaginosis may increase susceptibility to human immunodeficiency virus. J. Infect. Dis., v. 182, n. 2, p. 467-473, 2000.

SUNG, T. J. Ureaplasma infections in pre-term infants: Recent information regarding the role of Ureaplasma species as neonatal pathogens. Korean $\mathbf{J}$. Pediatr., v. 53, p. 989-993, 2010.

SUTTON, M.; STERNBERG, M.; KOUMANS, E. H.; MCQUILLAN, G.; BERMAN, S.; MARKOWITZ, L. The prevalence of Trichomonas vaginalis infection among reproductive-age women in the United States, 2001-2004. Clin. Infect. Dis., v. 45, p. 1319-1326, 2007.

SWIDSINSKI, A., MENDLING, W., LOENING-BAUCKE, V., LADHOFF, A., SWIDSINSKI, W., HALE, L. P. \& LOCHS, H. Adherent biofilms in bacterial vaginosis. Obstet. Gynecol., n. 106, p. 1013-1023, 2005.

SWIDSINSKI, A., MENDLING, W., LOENING-BAUCKE, V., SWIDSINSKI, S., DORFFEL, Y., SCHOLZE, J., LOCHS, H. \& VERSTRAELEN, H. An adherent Gardnerella vaginalis biofilm persists on the vaginal epithelium after standard therapy with oral metronidazole. Am. J. Obstet. Gynecol., v. 198, n. 97. p. 1-6, 2008.

SWYGARD, H.; SENA, A. C.; HOBBS, M. M.; COHEN, M. S. Trichomoniasis: clinical manifestations, diagnosis and Management. Sex. Transm. Infect., v. 80, p. 91-95, 2004.

TAKAHASHI, S.; TAKEYAMA, K.; MIYAMOTO, S.; ICHIHARA, K.; MAEDA, T.; KUNISHIMA, Y.; MATSUKAWA, M.; TSUKAMOTO, T. Detection of Mycoplasma genitalium,Mycoplasma hominis, Ureaplasma urealyticum, and Ureaplasma parvumDNAs in urine from asymptomatic healthy young Japanese men. Journal of Infection and Chemotherapy, v.12, n. 5, p. 269-271, 2006.

TANAKA, V. A.; FAGUNDES, L. J.; CATAPAN, A.; GOTLIEB, S. L. D.; BELDA JUNIOR, W.; ARNONI, M.; SOREANO, R.; MORAES, F. R. B. Perfil epidemiológico de mulheres com vaginose bacteriana, atendidas em um ambulatório de doenças sexualmente transmissíveis, em São Paulo, SP. An. Bras. Dermatol., v. 82, n. 1, p. 41-46, 2007.

TANG, J.; ZHOU, L.; LIU, X.; ZHANG, C.; ZHAO, Y.; WANG, Y. Novel multiplex real-time PCR system using the SNP technology for the simultaneous diagnosis of Chlamydia trachomatis, Ureaplasma parvum and Ureaplasma urealyticum and genetic typing of serovars of $C$. trachomatis and $U$. parvum in NGU. Molecular and Cellular Probes, v. 25, p. 55-59, 2011.

TAYLOR, B. D.; HOLZMAN, C. B.; FICHOROVA, R. N.; TIAN, Y.; JONES, N. M.; FU, W.; SENAGORE, P. K. Inflammation biomarkers in vaginal fluid and preterm delivery. Human Reproduction, v. 28, n. 4, p. 942-952, 2013. 
TAYLOR-ROBINSON, D. JENSEN, J. S. Mycoplasma genitalium: from Chrysalis to Multicolored Butterfly. Clin. Microbiol. Rev., v. 24, n. 3, p. 498, 2011.

TAYLOR-ROBINSON, D.; JENSEN, J. S.; SVENSTRUP, H.; STACEY, C. M. Difficulties experienced in defining the microbial cause of pelvic inflammatory disease. Int. J. STD AIDS., v. 23, p. 18, 2012.

TENG, L. J.; HO, S. W.; HO, H. N.; LIAW, S. J.; LAI, H. C.; LUH, K. T. Rapid detection and biovar differentiation of Ureaplasma urealyticum in clinical specimens by PCR. J. Form. Med. Assoc., v. 94, p. 396-400, 1995.

TERVONEN, T.; RAUNIO, T. Polymorphisms in the CD14 and IL-6 genes associated with periodontal disease. J. Clin. Periodontol., v. 34, n. 5, p. 377-383, 2007.

TIBALDI, C.; CAPPELLO, N.; LATINO, M. A.; MASUELLI, G.; MARINI, S.; BENEDETTO, C. Vaginal and endocervical microorganisms in symptomatic and asymptomatic non-pregnant females: risk factors and rates of occurrence. Clin. Microbiol. Infect., v. 15, p. 670-679, 2009.

TOTH, M.; PATTON, D.L.; CAMPBELL, L.A.; et al. Detection of chlamydial antigenic material in ovarian, prostatic, ectopic pregnancy and semen samples of culture-negative subjects. Am. J. Reprod. Immunol., v. 43, n. 4, p. 218-222, 2000.

TREVILATTO, P. C.; SCAREL-CAMINAGA, R. M. Polymorphism at position -174 of IL-6 gene is associated with susceptibility to chronic periodontitis in a Caucasian Brazilian population. J. Clin. Periodontol., v. 30, n. 5, p. 438-442, 2003.

ULICH, T.; GUO, K.; REMICK, D.; DEL CASTILLO, J.; YIN, S. Endotoxin-induced cytokine gene expression in vivo, III: IL-6 mRNA and serum protein expression and the in vivo hematologic effects of IL-6. J. Immunol., v. 146, p. 2316-2323, 1991.

USANGA, V. U.; ABIA-BASSEY, L.; INYANG-ETOH, P. C.; UDOH, S.; ANI, F.; ARCHIBONG, E. Prevalence of Sexually Transmitted Diseases in Pregnant and Non-pregnant women in Calabar, Cross River State, Nigeria. The Internet Journal Of Gynecology and Obstetrics, v. 14, 2010.

VAN DER POL, B.; WILLIAMS, J. A.; ORR, D. P.; BATTEIGER, B. E.; FORTENBERRY, J. D. Prevalence, Incidence, Natural History, and Response to Treatment of Trichomonas vaginalis Infection among Adolescent Women. The Journal of Infectious Diseases, v. 192, p. 192:2039-2044, 2005.

VAN KUPPEVELD, F. J. M.; VAN DER LOGT, J. T. M.; ANGULO, A. F.; VAN ZOEST, M. J.; QUINT, W. G. V.; NIESTERS, J. M.; GALAMA, J. M. D.; MELCHERS, W. J. G. Genus and Species-Specific Identification of Mycoplasmas by $16 \mathrm{~S}$ rRNA Amplification. Appl. Environ. Microbiol., v. 58, p. 2606-2615, 1992. 
VANCUTSEM, E.; SOETENS, O.; BREUGELMANS, M.; FOULON, W.; NAESSENS, A. Modified real-time PCR for detecting, differentiating, and quantifying ureaplasma urealyticum and Ureaplasma parvum. Journal of Molecular Diagnostics, v. 13, n. 2, p. 206-212, 2011.

VOZAROVA, B.; FERNANDEZ-REAL, J. M.; KNOWLER, W. C.; GALLART, L.; HANSON, R. L.; GRUBER, J. D.; RICART, W.; VENDRELL, J.; RICHARD, C.; TATARANNI, P. A.; WOLFORD, J. K. The interleukin-6 (-174) G/C promoter polymorphism is associated with type-2 diabetes mellitus in Native Americans and Caucasians. Hum. Genet., v. 112, p. 409-413, 2003.

WAITES, K. B.; CHELONKA, R. L.; XIAO, L.; PETA, L.; NOVY, G. M. J. Congenital and opportunistic infections: Ureaplasma species and Mycoplasma hominis. Seminars in Fetal \& Neonatal Medicine, v. 14, n. 3, p. 190-199, 2009.

WAITES, K. B.; KATZ, B.; SCHELONKA, R. L. Mycoplasmas and Ureaplasmas as neonatal pathogens. Clin. Microbiol. Rev., v. 18, p. 757-789, $2005 a$.

WAITES, K.; TALKINGTON, D. new developments in human diseases due to mycoplasmas. In: BLANCHARD, A.; BROWNING, G. (Ed.). Mycoplasmas, Molecular Biology Pathogenicity and Strategies for Control. Norfolk, U.K: Horizon Bioscience, 2005b. p. 289-355.

WALKER, J.; FAIRLEY, C. K.; BRADSHAW, C. S.; TABRIZI, S. N.; CHEN, M. Y.; TWIN, J.; TAYLOR, N.; DONOVAN, B.; KALDOR, J. K.; MCNAMEE, K.; URBAN, E.; WALKER, S.; CURRIE9, M.; BIRDEN, H.; BOWDEN, F.; GUNN, J.; PIROTTA, M.; GURRIN, L.; HARINDRA, V.; GARLAND, S.; HOCKING, J. S. The difference in determinants of Chlamydia trachomatis and Mycoplasma genitalium in a sample of young Australian women. BMC Infectious Diseases, v. 11, n. 35, 2011.

WEISSENBACHER, T.; WALTER, C.; MYLONAS, I.; SCHOLZ, C.; GINGELMAIER, A.; FRIESE, K. Interleukin-6, interleukin-10 and interleukin-12 in vaginal fluid from women with bacterial vaginosis. Arch Gynecol Obstet., v. 281, p. 77-80, 2010.

WEISSENBACHER, T.; WALTER, C.; MYLONAS, L.; SCHOLZ, C.; GINGELMAIER, A.; FRIESE, K. Interleukin-6, interleukin-10 and interleukin-12 in vaginal fluid from women with bacterial vaginosis. Arch. Gynecol. Obstet., v. 281, p. 77-80, 2010.

WIESLANDER, A.; BOYER, M. J.; WROBLEWSKI, H. Membrane Protein structure. In: MANILOFF J.; MCELHANEY, R. N.; FINCH L.R.; BASEMAN J. B. (Ed.). Mycoplasmas: molecular biology and pathogenesis. Washington: American Society for Microbiology, 1992. p. 93-112.

WIESNER, P. J.;THOMPSON, S. E. III. Gonococcal diseases. Dis. Mon., v. 26, p. $1-44,1980$. 
WITKIN, S. S.; LINHARES, I.; GIRALDO, P.; JEREMIAS, J.; LEDGER, W. J. Individual immunity and susceptibility to female genital tract infection. Am. J. Obstet. Gynecol., v. 183, n. 1, p. 252-256, 2000.

WORLD HEALTH ORGANIZATION (WHO). Sexually transmitted infections (STIs). The importance of a renewed commitment to STI prevention and control in achieving global sexual and reproductive health. Geneva: 2013. Disponível em: <http://apps.who.int/iris/bitstream/10665/82207/1/WHO_RHR_13.02_eng.pdf>. Acesso em: 11 Jul. 2013.

WORLD HEALTH ORGANIZATION (WHO). Emergence of multi-drug resistant Neisseria gonorrhoeae - Threat of global rise in untreatable sexually transmitted infections. Geneva: 2011. Disponível em: <http://www.who.int/reproductivehealth/publications/rtis/who_rhr_11_14/en/index. html >. Acesso em: 11 Abr. 2013.

WORLD HEALTH ORGANIZATION. Global incidence and prevalence of selected curable sexually transmitted infections: 2008-2012. Disponível em <http://apps.who.int/iris/bitstream/10665/75181/1/9789241503839_eng.pdf>.

Acesso em: 11 Abr. 2013.

WORLD HEALTH ORGANIZATION. Global prevalence and incidence of selected curable sexually transmitted infections: overview and estimates. Geneva: 2001. Disponível em: <http://www.who.int/hiv/pub/sti/who_hiv_aids_2001.02.pdf>. Acesso em $11 \mathrm{Abr}$. 2013.

WORLD HEALTH ORGANIZATION. Sexually Transmitted and Other reproductive infectious. A guide to essential practice, 2005.

XIAO, L.; GLASS, J. I.; PARALANOV, V.; YOOSEPH, S.; CASSELL, G. H.; DUFFY, L. B.; WAITES, K. B. Detection and Characterization of Human Ureaplasma Species and Serovars by Real-Time PCR. Journal of Clinical Microbiology, v. 48, p. 2715-2723, 2010.

XIAO, L.; PARALANOV, V.; GLASS, J. I.; DUFFY, L. B.; ROBERTSON, J. A.; CASSELL, G. H.; CHEN, Y.; WAITES, K. B. Extensive Horizontal Gene Transfer in Ureaplasmas from Humans Questions the Utility of Serotyping for Diagnostic Purposes. Journal of Clinical Microbiology, v. 49, n. 8, p. 2818-2826, 2011.

YAMAZAKI, T.; MATSUMOTO, M.; MATSUO, J.; ABE, K.; MINAMI, K.; YAMAGUCHI, $\mathrm{H}$. Frequency of Chlamydia trachomatis in Ureaplasma-positive healthy women attending their first prenatal visit in a community hospital in Sapporo, Japan. BMC Infectious Diseases, v. 12, p. 82, 2012.

YOU, X. X.; ZENG, Y. H.; WU, Y. M. Interactions between mycoplasma lipidassociated membrane proteins and the host cells. J. Zhejiang Univ. Sci. B., v.7, n. 5, p. 342-350, 2006. 
ZARFFARD, M. R.; SAIFUDDIN, M.; SHA, B. E.; SPEAR, G. T. Detection of bacterial vaginosis-related organisms by real-time $P C R$ for Lactobacilli, Gardnerella vaginalis and Mycoplasma hominis. FEMS Immunology and Medical Microbiology, n. 34, p. 277-281, 2002.

ZDRODOWSKA-STEFANOW, B.; KŁOSOWSKA, W. M.; OSTASZEWSKAPUCHALSKA, I.; BUtHAK-KOZIOK, V.; KOTOWICZ, B. Ureaplasma urealyticum and Mycoplasma hominis infection in women with urogenital diseases. Adv. Med. Sci., v. 51, p. 250-253, 2006.

ZIMMERMAN, C. R.; ROSENGARTEN, R.; SPERGSER, J. Interaction of the putative tyrosine recombinases RipX (UU145), XerC (UU222), and CodV (UU529) of Ureaplasma parvum serovar 3 with specific DNA. FEMS Microbiol. Lett., v. 340, p. 55-64, 2013.

ZIMMERMAN, C. R.; ROSENGARTEN, R.; SPERGSER, J. Ureaplasma antigenic variation beyond MBA phase variation: DNA inversions generating chimeric structures and switching in expression of the MBA N-terminal paralogue UU172. Molecular Microbiology, v. 79, n. 3, p. 663-676, 2011. 


\section{APÊNDICE A - Questionário}




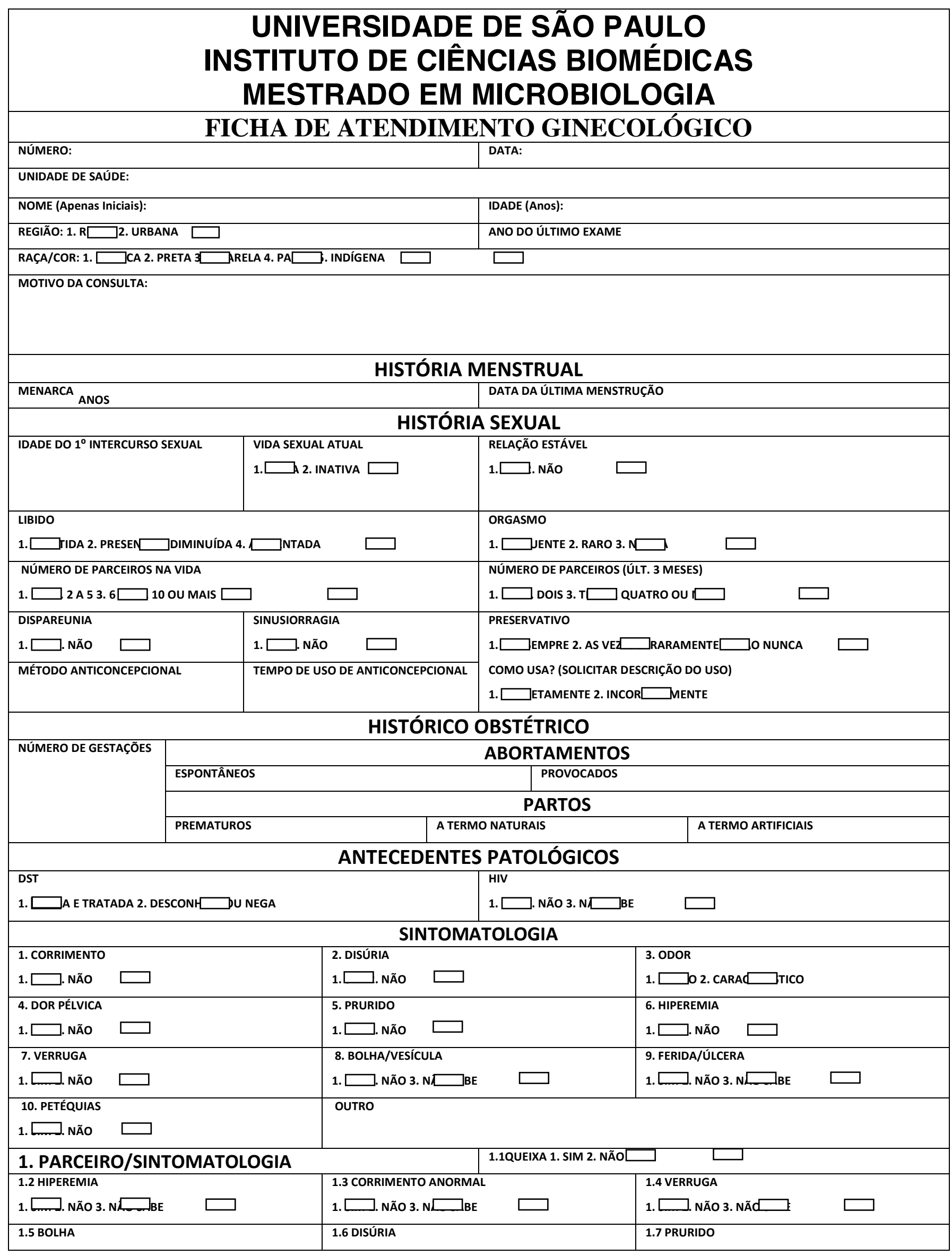




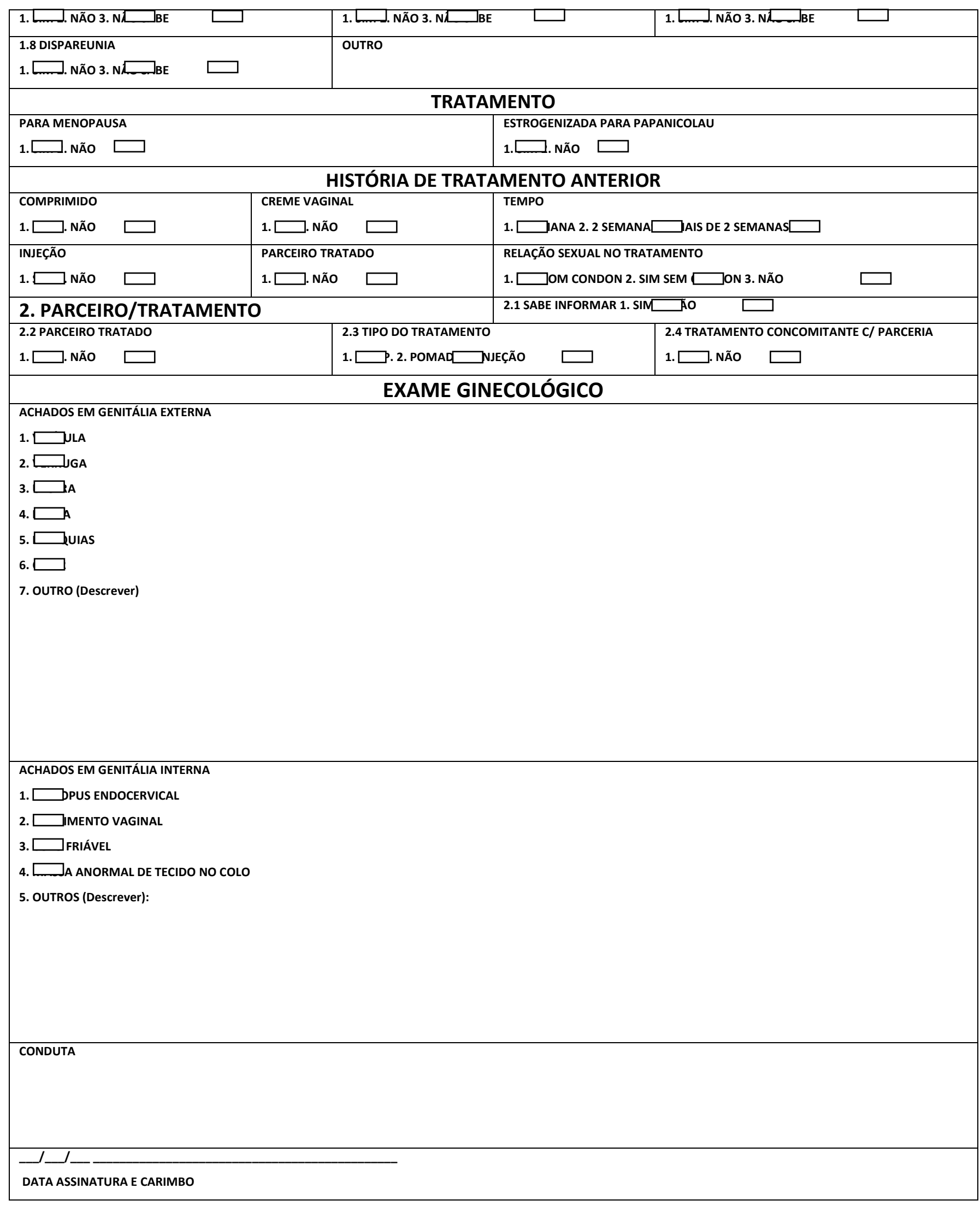

